$$
\text { UNIVERSIDADE DE SÃO PAULO }
$$

FACULDADE DE FILOSOFIA LETRAS E CIÉNCIAS HUMANAS DEPARTAMENTO DE GEOGRAFIA

PROGRAMA DE PÓS-GRADUAÇÃO EM GEOGRAFIA FÍSICA

\title{
Evolução Urbana e Dinâmica da Paisagem em Setores Periféricos da Metrópole Paulistana: \\ O Caso de Taboão da Serra-SP
}

Wellison Tatagiba de Araujo

Tese apresentada ao Programa de PósGraduação em Geografia Física, do Departamento de Geografia da Faculdade de Filosofia Letras e Ciências Humanas da Universidade de São Paulo, para a obtenção do título de Doutor em Geografia Física.

Orientador: Prof. Dr. Adilson Avansi de Abreu 


$$
\text { UNIVERSIDADE DE SÃO PAULO }
$$

FACULDADE DE FILOSOFIA LETRAS E CIÉNCIAS HUMANAS DEPARTAMENTO DE GEOGRAFIA

PROGRAMA DE PÓS-GRADUAÇÃO EM GEOGRAFIA FÍSICA

\title{
Evolução Urbana e Dinâmica da Paisagem em Setores Periféricos da Metrópole Paulistana: \\ O Caso de Taboão da Serra-SP
}

\author{
Wellison Tatagiba de Araujo
}


ARAUJO, WELLISON TATAGIBA de

Evolução Urbana e Dinâmica da Paisagem em Setores Periféricos da Metrópole Paulistana: O Caso de Taboão da Serra-SP-São Paulo,2010.231 p.

Tese (Doutorado) - FFLCH-Faculdade de Filosofia Letras e Ciências Humanas. Departamento de Geografia.

1. Estrato geográfico 2. Uso da terra 3. Fotogrametria, 4.Processos geoecológicos 5. Processos sócioreprodutores 6. Geossistema. 
Este trabalho é dedicado à todos aqueles que contribuíram para meu crescimento intelectual e espiritual. Aos meus pais, Joseval e Anatália e aos meus irmãos. 


\section{AGRADECIMENTOS}

Este trabalho é o resultado de um esforço intelectual e até mesmo físico, cujo fim não seria atingido se não fosse pelo apoio de algumas pessoas importantes neste processo.

Agradeço ao meu orientador Prof. Dr. Adilson Avansi de Abreu, pela paciência e suporte intelectual que foi de grande valia na construção da pesquisa. Aos meus pais Joseval e Anatália pelo constante apoio e incentivo. À Valéria, à Fabiana Akyiama pelas trocas de idéias, aos colegas de disciplinas, à Prefeitura de Taboão da Serra em especial ao Laboratório de Cartografia.

Agradeço ao criador pela oportunidade de crescimento e desenvolvimento espiritual, no qual se constituiu numa fase de extrema importância para a elaboração da tese e no esclarecimento de pontos obscuros no caminho trilhado.

Por último agradeço à família Sirna pelo apoio e em especial ao amigo de todas as horas Wilson Sirna pelo apoio incondicional e claro, ao Fábio Gomes pela compreensão, amizade e importância. 


\section{ACRÔNIMOS}

\begin{tabular}{|c|c|}
\hline $\begin{array}{l}\text { TGS } \\
\text { RMSP } \\
\text { SIG } \\
\text { SEADE }\end{array}$ & $\begin{array}{l}\text { Teoria Geral dos Sistemas } \\
\text { Região Metropolitana de São Paulo } \\
\text { Sistema de Informação Geográfica } \\
\text { Fundação Sistema Estadual de Análise de }\end{array}$ \\
\hline$A B C D$ & $\begin{array}{l}\text { Santo André, São Bernardo, São Caetano do } \\
\text { Sul } \\
\text { e Diadema }\end{array}$ \\
\hline sW & Sudoeste \\
\hline NE & Nordeste \\
\hline MNT & Modelo Numérico de Terreno \\
\hline $\begin{array}{l}\text { BDG } \\
\text { CSIRO }\end{array}$ & $\begin{array}{l}\text { Banco de Dados Geográfico } \\
\text { (Commonwealth Scientific and Industrial }\end{array}$ \\
\hline $\begin{array}{l}\text { INPE } \\
\text { DPI } \\
\text { CBERS }\end{array}$ & $\begin{array}{l}\text { (Instituto Nacional de Pesquisas Espaciais) } \\
\text { (Departamento de Processamento de Imagens) } \\
\text { China and Brazil Environmental Research } \\
\text { Satelitte }\end{array}$ \\
\hline SPRING & $\begin{array}{l}\text { Sistema de Processamento de Informações } \\
\text { Georreferenciadas }\end{array}$ \\
\hline $\begin{array}{l}\text { CPRM } \\
\text { CGE } \\
\text { DAEE } \\
\text { INMET } \\
\text { TIN } \\
\text { MTST } \\
\text { CN }\end{array}$ & $\begin{array}{l}\text { Companhia de Pesquisas de Recursos Minerais } \\
\text { Central de Gerenciamento de Emergências } \\
\text { Departamento de Águas e Energia Elétrica } \\
\text { Instituto Nacional de Meteorologia } \\
\text { Triangulated Irregular Network } \\
\text { Movimento dos Trabalhadores Sem-Teto } \\
\text { Curva de Nível }\end{array}$ \\
\hline
\end{tabular}




\section{LISTA DE FIGURAS}

Figura 1 -Localização da área de estudo .........................11 Figura 2 -Classificação Morfoescultural de SP e Taboão da Serra

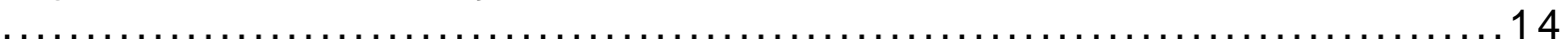
Figura 3 -Compartimentação do relevo Paulista, IPT, 1981.

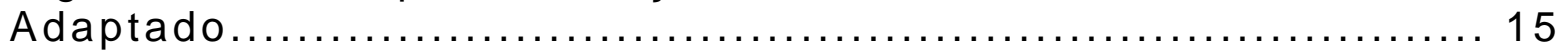

Figura 4 -A esfera do relevo segundo Budel (1969) .............18 Figura 5 - Modelo do georelevo de Taboão da Serra, adaptado a partir de Budel (1969) e Kugler (1976, apud Abreu, 1985.........19 Figura 6 -Taboão da Serra-Sub-bacias hidrográficas.............21 Figura 7-Representação esquemática da atmosfera urbana: camada limite da influência urbana (CLU); camada limite do dossel urbano (CLD); camada limite rural

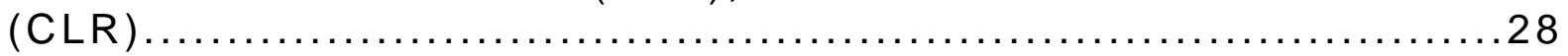

Figura 8-Captação de Dados em sensoriamento remoto:trajetórias da radiação eletromagnética......................................6 63 Figura 9 -Síntese das diferentes formas de vulnerabilidade e suas relações............................................................ 76

Figura 10- 4 Níveis da Pesquisa Geográfica.......................79 Figura 11 -Esquema modificado da interpretação dos 4 níveis da pesquisa geográfica............................................. 88 Figura12-Os níveis de procedimentos da Pesquisa em Geografia................................................... 89

Figura 13-Totais pluviométricos - Posto Cidade Universitária/USP - Período:1974a 1982...........................................94 Figura14-Totais pluviométricos - Posto: Cidade Universitária/USP


Figura 15-Totais pluviométricos - Posto: Butantã - Período:2000 a

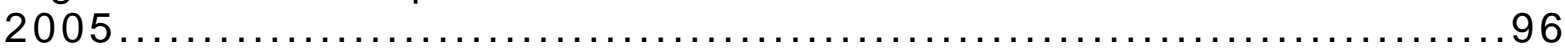

Figura 16 -Normais pluviométricas e médias mensais no período de 30 anos na RMSP......................................... 101 Figura 17 -Climograma Ombrotérmico de Gaussen................104 Figura 18 -Climograma Ombrotérmico de GAUSSEN .Determinação de Período Seco - Posto Cidade Universitária

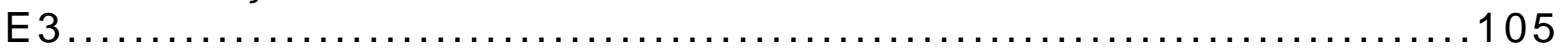

Figura 19 -Climograma Ombrotérmico de GAUSSEN Determinação de Período Seco - Posto CGE/Butantã entre

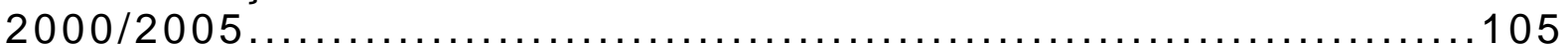

Figura 20 -Taboão da Serra/SP - Hipsometria/MNT..............109

Figura 21 -Taboão da Serra/SP - Hipsometria...................113

Figura 22 -Taboão da Serra/SP - Carta Declividades.............116

Figura 23 -Perfil hipsométrico SW/NE .........................117

Figura 24 -Falhas transcorrentes locais.......................... 118

Figura 25 -Embasamento geológico............................ 119

Figura 26 -População total residente............................126

Figura 27 -Área do Parque Pinheiros - Construções com melhornível de elaboração e acabamento, à direita Conjunto Habitacional Popular.............................................. 130 Figura 28 -População masculina residente.....................141 
Figura 29 -Evolução da população por sexo......................143 Figura 30 -Evolução da população..............................144 Figura 31 -Parque Poá I ao alto e vista aérea da Régis Bittencourt, trecho urbano no centro de Taboão da Serra parte inferior.... 146

Figura 32 - Fotografia aérea- Taboão da Serra - Bairro Parque das Hortênsias-06/2005 - Zona mista de ocupação - classes A,B e C. cobertura do solo por concreto e grandes áreas sem cobertura vegetal. 146

Figura 33 -Parque Pirajuçara II - Arredores do shopping Taboão: Uso intenso do solo..............................................150 Figura 34 -Exemplo de uso intenso do solo urbano: cobertura asfáltica: Entorno do Supermercado Extra........................150 Figura 35 -Remanescente de área verde intra-urbano: Cemitério da Saudade - Parque Pinheiros, cercado por áreas industriais ...................................................... 151 Figura 36 -Taboão da Serra/SP - Curva de Nível. e Hidrografia.................................................... 152 Figura 37 -Taboão da Serra - Articulação Fotogramétrica-

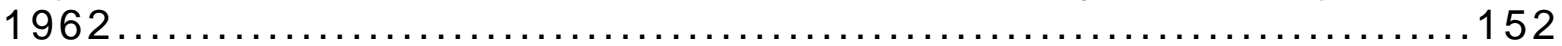

Figura 38 -Taboão da Serra - Ortofotos/Mosaico-1962...........164 Figura 39 -Taboão da Serra - Ortofoto e uso da terra-

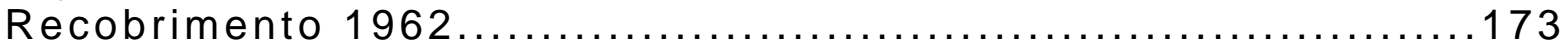

Figura 40 -Taboão da Serra - Uso da Terra-1962...............174

Figura 41 -Taboão da Serra - Recorte-Ortofoto/2007...........175

Figura 42 -Ortofotos e uso da terra-Recobrimento de $2007 \ldots \ldots 176$

Figura 43 -Taboão da Serra - Uso da Terra-2007...............183

Figura44-Infra-Estrutura Urbana/Domicílios com Espaço Suficiente - Taboão da Serra/2000.......................................184

Figura 45- Taboão da Serra: Uso da Terra $2007 \ldots \ldots \ldots \ldots \ldots \ldots \ldots 185$

Figura 46- Comparação da Infra-Estrutura Urbana/Domicílios com Espaço Suficiente-2000....................................... 189 


\section{LISTA DE FOTOS}

Foto 1 - Latossolo apresentando horizontes desenvolvidos......22

Foto 2 - Latossolo exposto e aparecimento de ravinas.............22 Foto 3 - Episódio de enchente em Taboão da Serra. 12/09. Av. Getulio Vargas..................................................25 Foto 4 - Episódio de enchente em Taboão da Serra/SP. 10/09Piscinão..........................................................

Foto 5 - Recorte de talude e latossolo. Vila Indiana..............34 Foto 6 - Taboão da Serra em 1975-Área onde hoje encontra-se



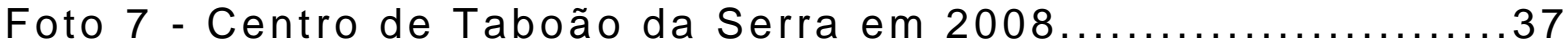
Foto 8 - Zona de ocupação de encostas e retirada da proteção vegetal natural....................................................70 Foto 9 - Vila Indiana:Ocupação desordenada...................111 Foto 10 - Vila Indiana:Construção de baixo padrão.............111 Foto 11 - Bairro São Judas.Assentamento urbano precário em feição geomorfológica de anfiteatro ocupada pela população de baixo poder aquisitivo .......................................... 112 Foto 12 - Feição de anfiteatro ocupada: Jardim Intercap.........131 Foto 13 - Sequência da feição de anfiteatro ocupada: Jardim Intercap ......................................................131 Foto 14 - Área de morrarias, ocupadas por habitações de alto padrão........................................................131

Foto 15 - Área de morraria sendo modificada artificilamente pela ação privada com aval da prefeitura.............................131 Foto 16 - Cooperativa Vida Nova: Exemplo de ação privada sobre as formas: pavimentação de morros..............................131 Foto 17 - Visão lateral sul do Conj. Cooperativa Vida Nova. No vale entulhamento de córrego..................................131

Foto 18 - Vila Indiana: Avanço de habitações de baixo padrão sobre área de vegetação remanescente..........................132 Foto 19 - Vila Indiana: Ao fundo Vegetação remanescente sendo substituída por indústrias e habitações de baixo padrão ....................................................... 132 Foto 20 - Recorte de talude..................................133 Foto 21 - Episódio de inundação do córrego Pirajussara 17/12/09. Fonte: O Taboanense........................................134 Foto 22 - Vila Indiana/Taboão: Recorte de talude e construções com alvenaria à mostra......................................... 136 Foto 23 - Vila Indiana/Taboão: Solo instável/cobertura vegetal inadequada................................................... 137 Foto 24 - Pirajussara/Taboão:Região periférica - intensa

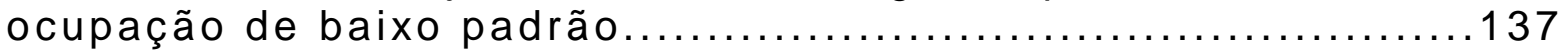
Foto 25 - Ribeirão Pirajussara - Entulhamento e fechamento de canal pelo matagal..............................................138 Foto 26 - Evento de transbordamento do piscinão divisa entre Butantã e Taboão da Serra ...................................... 138 
Foto 27 - Ocupação de Encostas/Vila Indiana......................144 Foto 28 - Maior remanescente de mata atlântica do município (Jardim Yolanda) ............................................ 149

Foto 29 - Encosta com contenção superficial de cimento e muro de arrimo em concreto. Bairro Pirajussara.......................158 Foto 30 - São Judas - Área ao fundo desocupada com aplicação de força policial................................................. 159 Foto 31 - São Judas - Área desocupada - Destroços de construções após aplicação de força policial......................160 Foto 32 - Vila Indiana - Desocupação e ocupação por empreendimentos particulares.................................. 160 Foto 33 - Pirajussara/Taboão:Córrego homônimo com esgotamento doméstico, concentração de lixo e proximidade de edificações no seu leito.............................................................. 163

Foto 34 - Centro de Taboão da Serra - Episódio de inundação em $01 / 12 / 2009$. Rua próxima ao piscinão. Observa-se a concentração de lixo e os prejuízos materiais de uma política de uso do solo

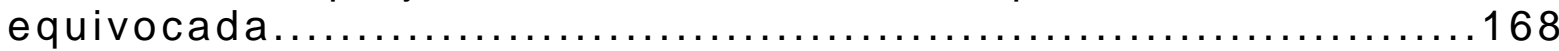

Foto 35 - Entalhamento do Córrego Poá.........................168 Foto 36 - Degradação ambiental do córrego João cachoeira lixo às suas margens................................................... 168 Foto 37-Desmatamento e ocupação atual de zonas íngremes.....................................................179

Foto 38 - Área classificada como equipamento urbano: Praça próximo ao centro do município, ao lado do córrego Poá........192 Foto 39 - Área de favelização, ocupação de loteamentos com retirada da cobertura vegetal de forma desordenada............193 Foto 40 - Ocupação intensiva e extensiva da área central do município........................................................ 194 Foto 41 - Única área de ocupação humana (moradia) com preservação da vegetação natural. Jardim Yolanda................195 


\section{LISTA DE TABELAS}

Tabela 1 - Subdivisões da atmosfera urbana......................26

Tabela 2 - Escalas de análise climática..........................27

Tabela 3 - Unidades climáticas naturais do município de São Paulo e adjacências.............................................29

Tabela 4 - Totaispluviométricos mês/ano-Período. 1974/1980

(Cidade Universitária- E3-251) ..............................98

Tabela5-Totais pluviométricos mês/ano-Período. 1981/1988

(Cidade Universitária-E3-251) ..............................98

Tabela 6 - Totais pluviométricos mês/ano-Período 1989/1993.

Cidade Universitária- E3-251.................................99

Tabela 7 - Totais pluviométricos mês/ano-Período 2000/2005.

Posto: Butantã-CGE.........................................101

Tabela 8 - Taboão da Serra - Unidades litoestratigráficas.......123

Tabela 9 - Classificação das rochas segundo a vulnerabilidade à

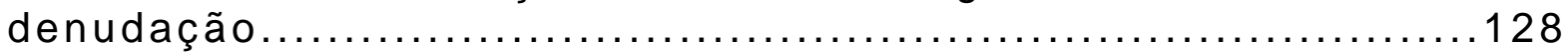

Tabela 10 - Evolução da população residente em Taboão da Serra/SP.1970/2007........................................142

Tabela 11 - Evolução da população residente em Taboão da Serra/SP, por situação de domicílio,e sexo no período de 1970 -

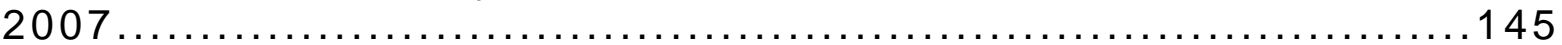

Tabela 12 - Base Cartográfica e Uso da Terra-1962/2007 - Taboão da Serra/SP-Classificação/Funções.............................171 Tabela 13 - Totais em porcentagem de ocupação de Uso da Terra-

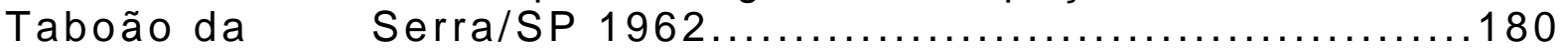
Tabela 14 - Totais em porcentagem de ocupação de Uso da Terra

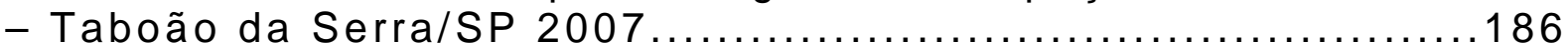
Tabela 15 - Habitação e Infra-estrutura urbana/2000............188 


\section{SUMÁRIO}

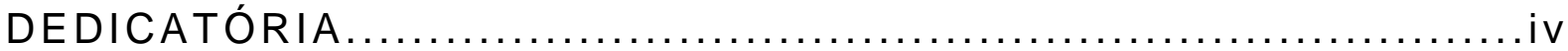

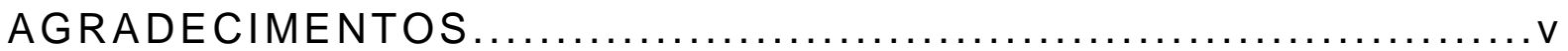

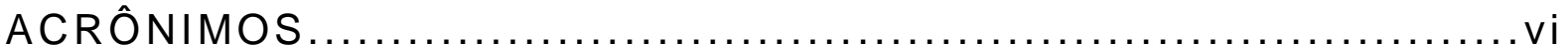

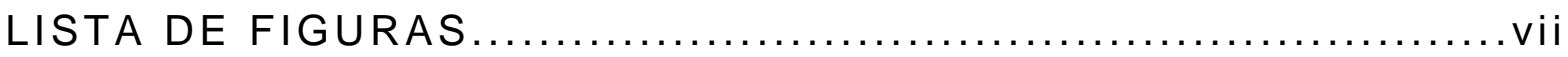

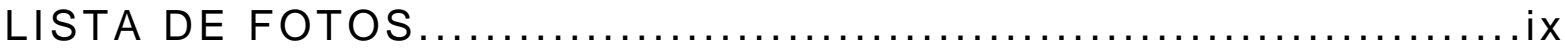

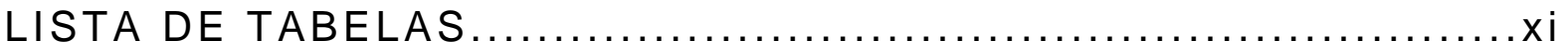

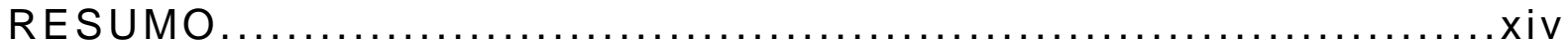

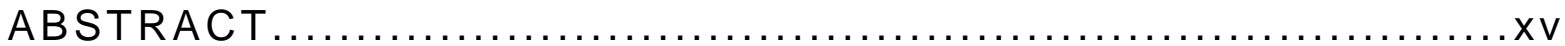

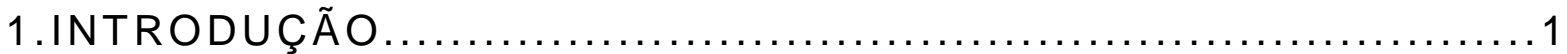

2. HIPÓTESE, OBJETIVOS E JUSTIFICATIVAS DA PESQUISA .....5

2.1 Hipótese de Estudo..........................................

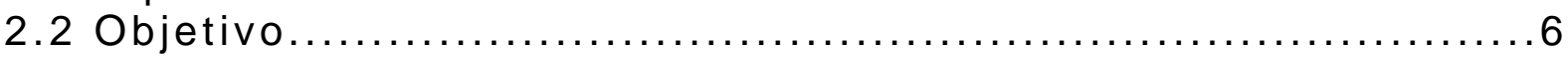

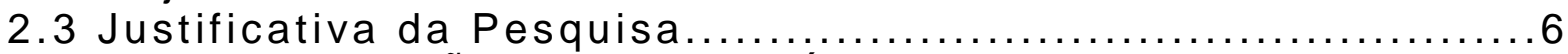

3.CARACTERIZAÇÃO GERAL DA ÁREA $\ldots \ldots \ldots \ldots \ldots \ldots \ldots \ldots \ldots \ldots \ldots$

3.1 Localização da Área da Pesquisa............................. 8

3.2 Caracterização Geomorfológica Relevo Regional.

e Local............................................................. 12

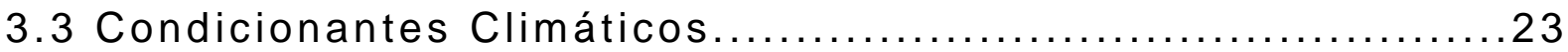

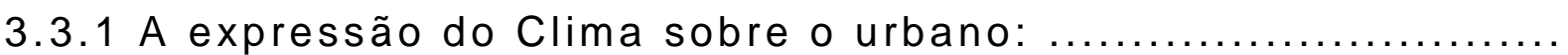

fenômeno das ilhas de calor...................................... 24

3.4 Embasamento Geológico.................................. 31

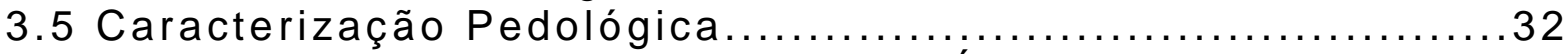

3.6 Processo Histórico de Ocupação da Área....................... 35

4.EMBASAMENTO TEÓRICO-CONCEITUAL $\ldots \ldots \ldots \ldots \ldots \ldots \ldots \ldots . \ldots \ldots$

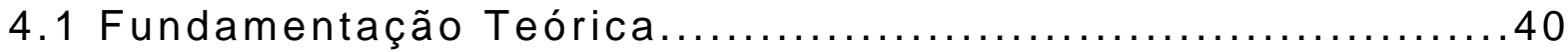

4.2 Embasamento Conceitual Ambiental......................... 44

4.2.1 O modelo geossistêmico e os problemas ambientais..........

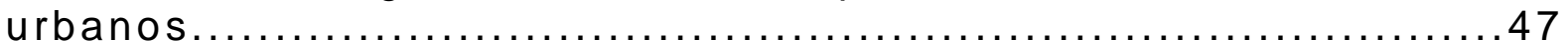

4.2.2 O conceito e a importância do sítio urbano................51

4.2.3 Características da energia no geossistema................54

4.2.4 Desenvolvimento da Geomorfologia........................55

4.3 Embasamento Conceitual Instrumental.......................56

4.3.1 Banco de Dados e os Sistemas de Informações ...............

Geográficas: Especificidades................................... 58

4.3.2 Uso da terra e o sensoriamento remoto....................61

4.3.3 Da contribuição da fotogrametria...........................66

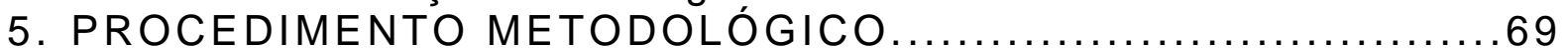

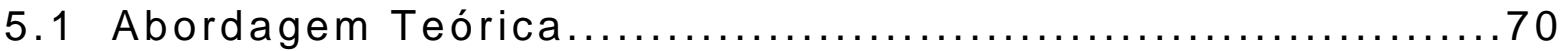

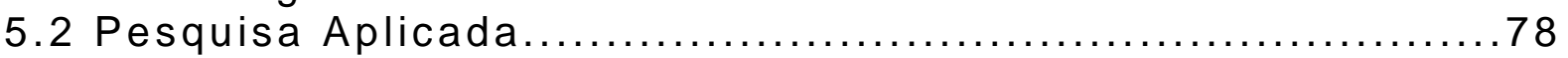

5.2 .1 Dados primários ........................................... 80

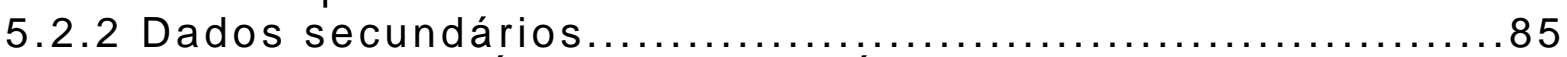

6.INSTRUMENTAL TÉCNICO DE ANÁLISE: Produtos Gráficos e



6.1 Dados Climáticos............................................ 91

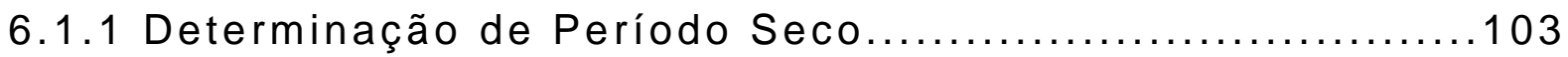

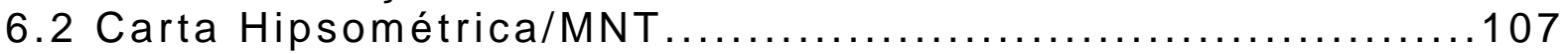

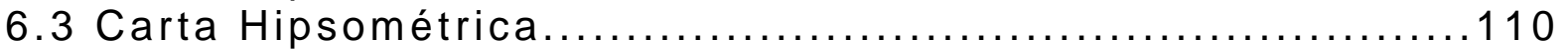

6.4 Carta Clinográfica.......................................... 114

6.5 Carta Geológica............................................ 
6.6 Cobertura Vegetal e os Processos Morfodinâmicos...........132

7. EVOLUÇÃO DEMOGRÁFICA .................................139

7.1 Evolução Demográfica de Taboão da Serra...................140

7.2 Intervenções Públicas: O Plano Diretor do Município.........147

7.2.1 Sistema de Áreas Verdes do Município......................148

7.2.2 Zonas Especiais de Interesse Social....................... 153

7.2.3 Áreas Sujeitas ao Direito de Preempção....................155

7.2.4 Áreas Homogêneas......................................... 155

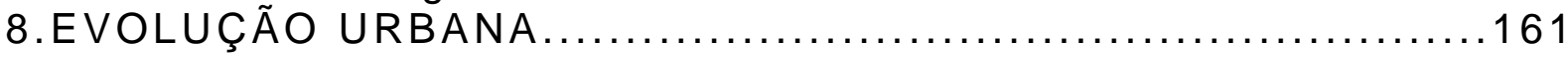

8.1 Evolução Urbana de Taboão da Serra.........................162

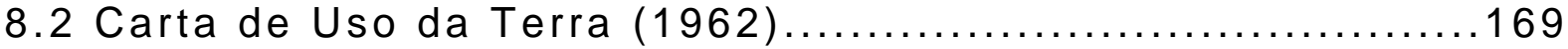

8.2.1 Características técnicas ................................... 169

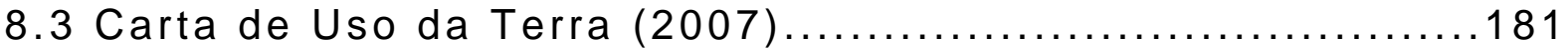

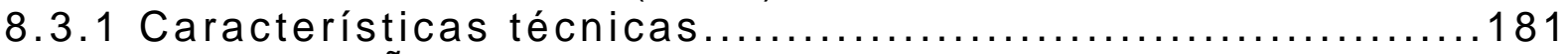

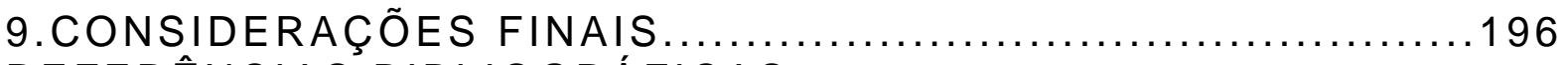

REFERÊNCIAS BIBLIOGRÁFICAS 


\section{RESUMO}

A pesquisa tem por objetivo, analisar as influências da urbanização concentrada (compacta), e de como essa característica altera as condições ambientais e o equilíbrio das formas de relevo local, modificando o estrato geográfico da paisagem.

Para essa análise, tivemos como suporte o mapeamento da evolução do uso da terra urbana em Taboão da Serra em dois momentos distintos, no período compreendido entre 1962 e 2007.

O uso da terra tem contornos distintos no contexto intraurbano, fato este que é traduzido pela evolução e pelo tipo de uso e ocupação dado à paisagem urbana em Taboão da Serra.

Os processos geoecológicos encontram-se modificados na sua gênese e na sua estrutura, o que resulta em formas mais antropizadas do que em décadas passadas.

A cidade de Taboão da Serra, é a sexta cidade mais compacta do Brasil, fato este que tem reflexos negativos sobre os processos naturais onde,, a morfogênese é dominante por conta do intenso uso da terra seja ele para fins imobiliários como também pelo processo de intensificação da cobertura da superfície por materiais que interrompem a percolação das águas pluviais associado à retirada da cobertura vegetal.

A escolha da cidade como área de estudo deu-se pelos motivos explicitados acima mas também, pelo fato de que através da comparação de dois momentos da ocupação urbana (1962 e 2007) que são caracterizadas pela intensificação do uso da terra (utilizando fotografias aéreas), é possível mapear e representar como o tipo de uso e ocupação pode comprometer em maior ou menor grau as condições geoecológicas de um geossistema.

As unidades de paisagem urbana serão compartimentadas tendo como finalidade a comparação para diagnosticar a relação atual entre relevo/solo e uso da terra nesta cidade, que serão representadas na carta de Uso da Terra.

\section{PALAVRAS-CHAVE}

Estrato geográfico, uso da terra, fotogrametria, processos geoecológicos, processos sócio-reprodutores, geossistema. 


\section{ABSTRACT}

The research aims to examine the influences of urbanization concentrated (compact), and how this feature changes the environmental conditions and the balance of local landforms by modifying the geographic stratum of the landscape.

For this analysis, we had to support the mapping of the evolution of urban land use in Taboão da Serra at two different times in the period between 1962 and 2007

The use of land has different contours in the intra-urban context, a fact that is translated by the change in type of use and occupation since the urban landscape in Taboão da Serra. Geoecological processes are modified in their genesis and structure, resulting in forms more disturbed than in decades past.

The city of Taboao da Serra, is the sixth most compact city of Brazil, a fact that has negative effects on natural processes where the dominant morphogenesis is due to the intense use of land be it for housing but also by the process of intensification of surface coverage by materials that disrupt the percolation of rainwater associated with the removal of the canopy.

The choice of the city as the study area took place for the reasons explained above but also by the fact that by comparing two moments of urban occupation (1962 and 2007) which are characterized by the intensification of land use (using aerial photographs) It is possible to map and represent the type of use and occupation can affect a greater or lesser degree the conditions of a geoecological geosystem.

The units of the urban landscape will be compartmentalized view to the comparison to diagnose the current relationship between topography/soil and land use in this city, which will be represented in the land use map.

\section{KEY WORDS}

Geographic stratum, land use, photogrametry, geoecological process, social-reproducers process, geossystems. 
[...] contexto científico é importante porque a Geografia Física não apenas reflete a influência de outras ciências, especialmente a das ciências da terra, tanto em seu desenvolvimento como em seu conteúdo, mas também as tendências internas e as pressões advindas da Geografia Humana.

\section{INTRODUÇÃO}

K.J. Gregory

As atividades resultantes do desenvolvimento e crescimento das cidades, impõem características marcantes sobre o solo urbano, as mudanças contínuas levadas à cabo pela constante reprodução do capital e do espaço urbano, expropriam e extrapolam todos os diagnósticos negativos que indicavam um "estresse" do meio-ambiente à curto e à médio prazo. O colapso do meio-ambiente, resultante das considerações feitas anteriormente, é demonstrado principalmente pelo processo de intensificação do uso da terra.

As pesquisas acadêmicas buscam cada vez mais uma proximidade maior acerca da discussão ambiental, esta proximidade se dá principalmente pelas crescentes mudanças ambientais. Os fatores geoecológicos por si, apresentam uma variedade de formas e de processos que atuam de maneira associada dinamizando o ambiente.

Do ponto de vista geográfico, o ambiente natural por assim se dizer, tem características intrínsecas que obedecem às leis naturais da evolução, que pode ser chamada de ciclo natural de evolução da paisagem. A Geografia é uma ciência ao mesmo tempo física e social, já que a mesma preocupa-se com a interpretação dos processos atuantes no meio físico e seus resultados sobre o meio social, pois tem como um dos objetivos interpretar os fluxos de energia que elaboram as formas e que recebem do homem modificações ou inputs.

Assim, a Geografia Física tem por objetivo investigar os fenômenos naturais, sempre inter-relacionados e que se 
caracterizam pelos processos dinâmicos de fluxos de energia e matéria entre partes de um todo indissociável.

Os processos físicos e químicos e as morfologias dos materiais definem os componentes que formam um significativo segmento denominado por Grigoriev (1968) de Estrato Geográfico da Paisagem, Ross (2006). Esse estrato geográfico é modificado pela ação antrópica caracterizada pelo intenso uso do solo urbano.Do ponto de vista geossistêmico, o meio-ambiente urbano e seus fluxos de energia, ecologicamente apresentam uma desorganização resultante dos impactos do uso do solo e da crescente modificação das estruturas naturais (solo, vegetação, hidrografia e clima etc.) associadas a um tipo característico de sítio urbano. O geossistema em geral, envolve um outro sistema bioquímico que tende a um estado uniforme em que os intercâmbios e interações tendem a fazer-se mínimos.

Se o sistema é aberto ocorrerá que para cada quantidade de energia que saia do sistema registre-se uma entrada: o sistema estará em ótimas condições de energia (estabilidade), com isto se chega ao conceito de "sistema aberto dinâmico", o qual apresenta um nível de organização que permite entradas e saídas de matérias e energia constantes e por conseguinte sua estabilidade. A energia e seus processos, particularmente o segundo princípio da termodinâmica ${ }^{1}$, tiveram também importância na elaboração da Teoria Geral dos Sistemas (TGS).

Sabemos que, em todo sistema fechado o fluxo de energia perpassa intrinsecamente sem influência externa ao mesmo. Na cidade de Taboão da Serra/SP, pertencente como área que abrange a Grande São Paulo ou Região Metropolitana, os

\footnotetext{
${ }^{1}$ A segunda lei da termodinâmica nos diz que embora a energia do universo permaneça constante, seu estado de desorganização tende a aumentar (o grau de desorganização chama-se entropia). Esta lei definida por CARNOT em 1824, afirma que para produzir trabalho a partir da energia térmica é indispensável dispor de diferença de temperatura.(Christofoletti,1995).
} 
impactos mostram-se cada vez maiores, tanto advindos da intensificação do uso da terra quanto da eliminação dos fluxos naturais dos córregos.

Nesta cidade, a despeito de sua posição e situação geográfica, o sítio urbano foi sendo gradualmente ocupado seguindo $o$ modelo vigente característico de um país subdesenvolvido: adensamento populacional, favelização, lançamento de lixo e dejetos em córregos, aliados à uma ausência de política de educação ambiental, a partir daí, configura-se esta cidade num exemplo típico de desestruturação ambiental, onde as condições geoecológicas foram intensamente modificadas pela ação antrópica indiscriminada, gerando um ônus negativo para o meio.

De acordo com Gerasimov apud (ROSS, 2006), os estudos ecológico-ambientais no âmbito da Geografia podem ser elaborados seguindo os seguintes princípios:

- Controle sobre as transformações do meio-ambiente originadas pelas atividades humanas-monitoramento antropogênico;

- Prognósticos geográfico-científicos das conseqüências que implicam a influência das atividades econômicas sobre o entorno (espaço físico-territorial);

- Prevenção, debilitamento e eliminação das calamidades naturais;

- Otimização do meio nos sistemas técnico-naturais que são criados pelo homem;

O fator energético é o combustível de qualquer geossistema, dado sua força motriz e suas características, a energia que perpassa o geossistema, seja ele antropizado ou não, tem uma 
natureza diversa, apresentando aceleração de fluxos, ou seja, de outputs e inputs.

Apesar da discussão que emergiu outrora no pensamento Geográfico, principalmente aqueles relacionados aos determinismos naturais, percebe-se que o avanço técnicocientífico teve um impacto positivo no que tange ao modo de apropriação da natureza, percebe-se no entanto que o domínio dos meios técnicos estão em poder de uma pequena parcela da sociedade.

O trabalho que ora se apresenta é uma tentativa de interpretar com a ajuda do geoprocessamento os padrões espaciais criados com a ocupação acelerada da cidade em questão, levando-se em consideração que estudos apoiados na abordagem geossistêmica, tendo como área de estudo territórios urbanos como o de Taboão da Serra ainda são escassos. 


\section{HIPÓTESE, OBJETIVOS E JUSTIFICATIVAS DA PESQUISA}

\subsection{Hipótese de Estudo}

A questão básica deste trabalho resume-se na busca da comprovação da hipótese de estudo, e que pode ser tratada pelo estudo da evolução urbana, principalmente na RMSP, para verificar como ela provocou e ainda provoca impactos ambientais que modificam as propriedades geoecológicas e desestruturam as condições naturais pré-estabelecidas, e em especial em Taboão da Serra, a despeito de sua diminuta área e do seu adensamento populacional e de construções.

Acreditamos que é possível se avaliar os condicionantes e suas respostas em nível geo-espacial (levando-se em consideração a escala de análise) através da combinação das propriedades geoecológicas pré-existentes com base em ferramentas de SIG's.

A comparação das mesmas em duas épocas diferentes tem como viés principal,a evolução do uso da terra balizadas pelo condicionante econômico.

Por fim pretende-se demonstrar que a dinâmica ambiental dos momentos selecionados, refletem as condições sócioambientais do município em cada época. As características naturais encontram-se atualmente profundamente modificadas, demonstrando que as trocas de energia dos ecótopos sofrem alterações nos seus fluxos pela predominância da morfogênese e pela crescente utilização da terra como mercadoria. 


\subsection{Objetivo}

A pesquisa tem como objetivo principal, a análise e interpretação referente à evolução urbana do município de Taboão da Serra/SP com base em dois momentos diferentes.

A análise da evolução do uso da terra terá como referência dois vôos fotogramétricos realizados em (1962 e 2007) e será centralizada na comparação e interpretação das cartas temáticas das unidades de paisagem intra-urbanas, identificadas em cada momento para avaliar seus diferentes graus de ocupação, a dinâmica dos processos e o impacto no estrato geográfico da paisagem local.

\subsection{Justificativa da Pesquisa}

No decorrer das últimas décadas muitas pesquisas foram realizadas no intuito de compreender as mudanças e as transformações temporais e também espaciais dos padrões da paisagem urbana, com a finalidade de se obter respostas mais claras sobre a dinâmica do uso da terra, principalmente no seu aspecto intra-urbano.

As pesquisas relacionadas ao estudo do meio ambiente tem procurado analisar e interpretar essas mudanças que ocorrem na paisagem urbana, tendo como fim a compreensão da dinâmica do uso da terra. A necessidade de realização de tais estudos, advém das respostas que o meio ambiente imprime sobre o modo de vida urbano, caracterizada pelas mudanças nos padrões de pluviosidade e médias térmicas o que provoca a curto e longo prazo a redefinição dos processos e das formas resultantes a partir da mesma sobre o meio urbano, mudanças estas caracterizadas pelo redimensionamento do balanço entre pedogênese e morfogênese. 
A ocupação indiscriminada de áreas ambientalmente estáveis, acaba por causar uma instabilidade estrutural quando da ação de elevada pluviosidade juntamente com o entulhamento de várzeas ou áreas ribeirinhas (córregos). O relevo e suas feições (vertentes, vales e espigões) por sua vez, é o subsistema que sofre maior influência do adensamento populacional principalmente em regiões de climas tropicais.

A desestruturação de áreas adjacentes a córregos e rios tributários, a partir da derrubada da mata ciliar e da introdução da cobertura asfáltica em áreas antes protegidas gera, como foi dito anteriormente a alteração dos sistemas morfogenéticos, que estão ligados diretamente ao balanço de energia negativo no sistema ambiental (superioridade da morfogênese sobre a pedogênese).

O córrego Pirajussara localizado na divisa das cidades de Taboão da Serra e São Paulo apresenta atualmente uma problemática que soma-se à toda desestruturação ambiental que encontra-se instalada nesta região, que é representada pela influência da ação antrópica sobre o relevo e suas variações espaciais (a interferência no condicionante geomorfológico).

A pesquisa justifica-se pelo fato de que os processos geoecológicos são modificados estruturalmente pela ocupação diferenciada do solo urbano, onde as características do uso da terra se dá de acordo com a capacidade econômica dos atores sociais, que por sua vez imprimem modificações cada vez mais aceleradas sobre o meio. No exemplo de Taboão da Serra, utilizaremos de 2 momentos distintos da ocupação da cidade para mapear e interpretar quais os níveis de modificação e impermeabilização foram impostas em duas áreas préselecionadas, tendo como suporte de análise 0 arcabouço geotecnológico (fotointerpretação) e a teoria geossistêmica. 


\section{CARACTERIZAÇÃO GERAL DA ÁREA}

\subsection{Localização da Área da Pesquisa}

A cidade de Taboão da Serra com aproximadamente 236.794 habitantes (Fundação SEADE/2007), situada na Região Metropolitana de São Paulo, é considerada como sendo "a sexta cidade mais compacta" do Brasil. A área de estudo é delimitada pelas coordenadas 2336'34" e 2339'36"de latitude Sul, 464'23'” 46\%49'45'de longitude Oeste com uma hipsometria média de aproximadamente $750 \mathrm{~m}$. Apresenta-se como sendo um desmembramento urbano oriundo da comarca de Itapecerica da Serra/SP (Fig. 01).

Localiza-se na sub-região Sudoeste da Região Metropolitana de São Paulo (RMSP). Ao Norte e a Leste, faz divisa com o município de São Paulo (distrito de Raposo Tavares e distritos de Vila Sônia e Campo Limpo, respectivamente); a Noroeste, com o município de Osasco; e ao Sul, com Embu das Artes (GOVÁGUA/USP, 2007).

A compactação da paisagem da cidade, representada pelo intenso uso do solo de características urbanas, impressiona pela sua fisionomia árida na extensão de sua paisagem conurbada. Com pouca cobertura vegetal, em comparação com outras cidades da região metropolitana de São Paulo tem intensa impermeabilização do solo modificando as propriedades geoecológicas, mas ainda apresenta enclaves expressivos, mas localizados, de remanescentes florestais.

Com uma altitude média $750 \mathrm{~m}$, a cidade encontra-se assentada em duas sub-bacias hidrográficas. Mais da metade do território é coberta pela sub-bacia do Córrego Poá que localiza-se à direita da Rodovia Régis Bittencourt no sentido capital interior. A sub-bacia do Córrego Pirajussara ocupa a margem esquerda da Rodovia e da área do município, correspondendo a menos da 
metade da área total. O córrego Poá apesar da sua maior área de irrigação constitui-se num tributário do córrego Pirajussara que é um dos mais importantes tributários do Rio Pinheiros em São Paulo, os quais estão inteiramente inseridos na Bacia Hidrográfica do Alto Tietê, apresentando o córrego Pirajussara uma ocupação muito forte da sua área de várzea.(BOUCINHAS et alii, 2006).

Sabe-se que as bacias hidrográficas tem um importante papel no ecossistema urbano pois, a mesma influencia a formação geomorfológica da superfície terrestre, sendo que, no caso do Brasil, o sistema hídrico é o veículo principal das mudanças ocorridas na superfície. (AB'SABER, 1957)

A paisagem urbana domina o espaço municipal, já que em Taboão da Serra residem 236.794 habitantes, representando $1,11 \%$ da população da região metropolitana, sendo seus 236.794 habitantes residentes na zona urbana, uma vez que Taboão da Serra não possui área rural (Fundação SEADE/2007). Com área de $20,5 \mathrm{~km}^{2}$, representando $0,26 \%$ da área da região metropolitana, sua densidade demográfica é de 11.562,21 habitantes por $\mathrm{km}^{2}$.

Isto representa espacialmente um impacto do uso da terra tanto qualitativamente quanto quantitativamente no que tange principalmente aos tipos de construções, pois muitos bairros apresentam insuficiência de serviços públicos essenciais (asfaltamento, esgoto, água tratada etc.) e que estão implantados sobre uma base física frágil, representado por vertentes, onde o ecossistema sofre rapidamente o impacto representado principalmente pelas perdas de solo.

Seus taludes foram drasticamente antropizados tanto pela implantação de rodovias, quanto de moradias, assim como pela instalação incessante de indústrias de bens de consumo duráveis e não duráveis principalmente a partir da década de 1970. 
Atualmente apresenta uma vegetação nativa residual, resultado da urbanização acelerada e pela ocupação das encostas, fato que contribui para a reativação de processos erosivos e de movimentos de massas nos meses de alta pluviosidade. (meses de Dezembro a Março). 
FIG. 01 - LOCALIZAÇÃO DA ÁREA DE ESTUDO - TABOÃO DA SERRA/SP
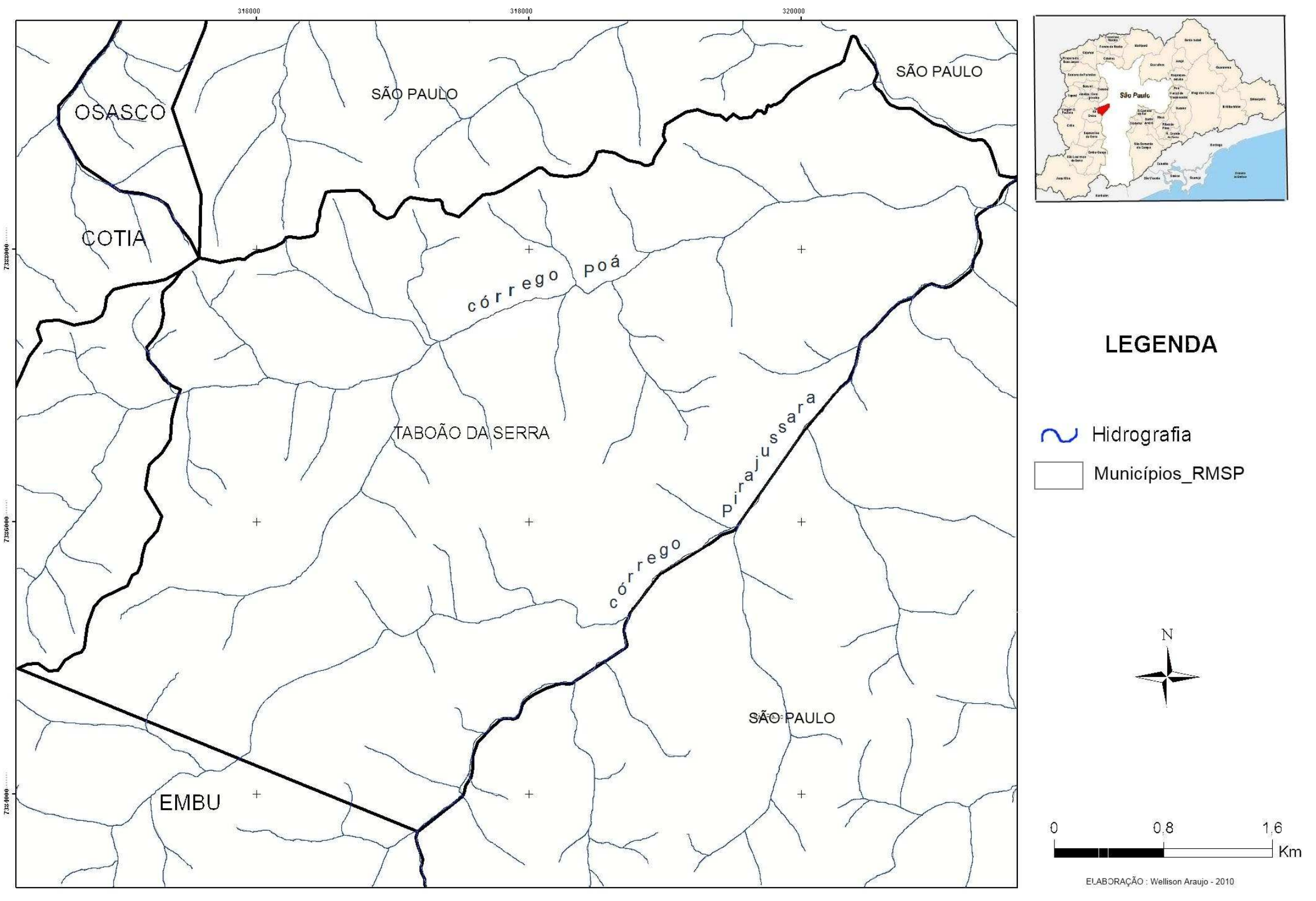


\subsection{Caracterização Geomorfológica do Relevo Regional e Local}

Compreende-se que a sociedade se organiza sobre uma base física, e que o sítio urbano exerce influência direta na disposição das construções, como também nos tipos de fenômenos que irão se instalar sobre o relevo, levando-se em consideração: quando, quanto e como se ocupou este sítio.

Considera-se o relevo e suas propriedades como fatores que influenciam diretamente a organização do espaço, posto que ele e sua dinâmica fornecem para a geografia uma das mais ricas fontes de leis espaciais e de movimentos de transformação da matéria na superfície do planeta, Abreu (1985).

O relevo é o suporte físico onde a vegetação e o clima deixam suas impressões, revelando a complexa interrelação entre os elementos naturais e o homem.

A dificuldade reside em levar à cabo um estudo integrado da paisagem, não esquecendo das características físicas como também das impressões humanas sobre este meio, elaborando dessa forma uma pesquisa com bases verdadeiramente geossistêmicas.

O relevo da RMSP, pela importância econômica dessa região no país, é em termos de investigação científica, um dos setores já bem estudados do Planalto Atlântico, tanto do ponto de vista geológico, como dos estudos clássicos de geomorfologia, Abreu (1983).

As condições físicas do relevo de Taboão da Serra, se diferenciam das cidades vizinhas por apresentar na sua extensão uma ocupação mais efetiva de suas formas. O entalhamento da bacia hidrográfica trabalhou o compartimento caracterizado por 
um planalto, característica esta que influenciou no tipo de ocupação humana dada à região.

Segundo Almeida (1964) o Estado de São Paulo é dividido em cinco grandes províncias (Fig. 02): Planalto Atlântico, Planalto Ocidental, Província Costeira, Depressão Periférica e Cuestas Basálticas. Taboão da Serra encontra-se na província denominada de PLANALTO ATLÂNTICO PAULISTA.

As unidades do relevo foram diferenciadas na classificação do relevo brasileiro realizada por Ross (1995), que teve como pressupostos as bases conceituais da dinâmica da relação entre as várias fases climáticas do Quaternário, a estrutura geológica como também as formas de relevo. Sendo assim, a tomamos como apoio para a nossa análise interpretativa caracterizando o relevo paulistano e da área de estudo.

Tomando como traçado uma secção no sentido SE/NO no estado de São Paulo (Fig. 03), temos como feições a PLANíCIE LITORÂNEA, que tem como características de origem uma região formada pela ação marinha e pela sedimentação, posteriormente surge o PLANALTO ATLÂNTICO (em cuja escarpa localiza-se a Serra do Mar), que corresponde a um escudo cristalino, apresentando em sua maioria rochas antigas e resistentes, sendo assim de difícil desgaste pelo intemperismo.

A DEPRESSÃO PERIFÉRICA, apresenta-se como uma área circundada pela escarpa do Planalto Atlântico e que tem aproximadamente $450 \mathrm{~km}$ de extensão por aproximadamente 100 $\mathrm{km}$ de largura em algumas partes. Após surgem as CUESTAS BASÁLTICAS, dando por sua vez lugar à maior área do relevo paulista, representado pelo PLANALTO OCIDENTAL, que são na sua totalidade regiões trabalhadas pelos agentes de erosão, principalmente sobre os sedimentos da borda da Bacia Sedimentar própria do Paraná. 
O município insere-se na zona do planalto paulistano (que por sua vez está incluso nas subzonas Colinas de São Paulo e Morrarias de Embu). De acordo com Ross (2006), dentro das grandes unidades geomorfológicas do Brasil, a região insere-se no grupo dos Planaltos e Serras do Atlântico-leste-sudeste.

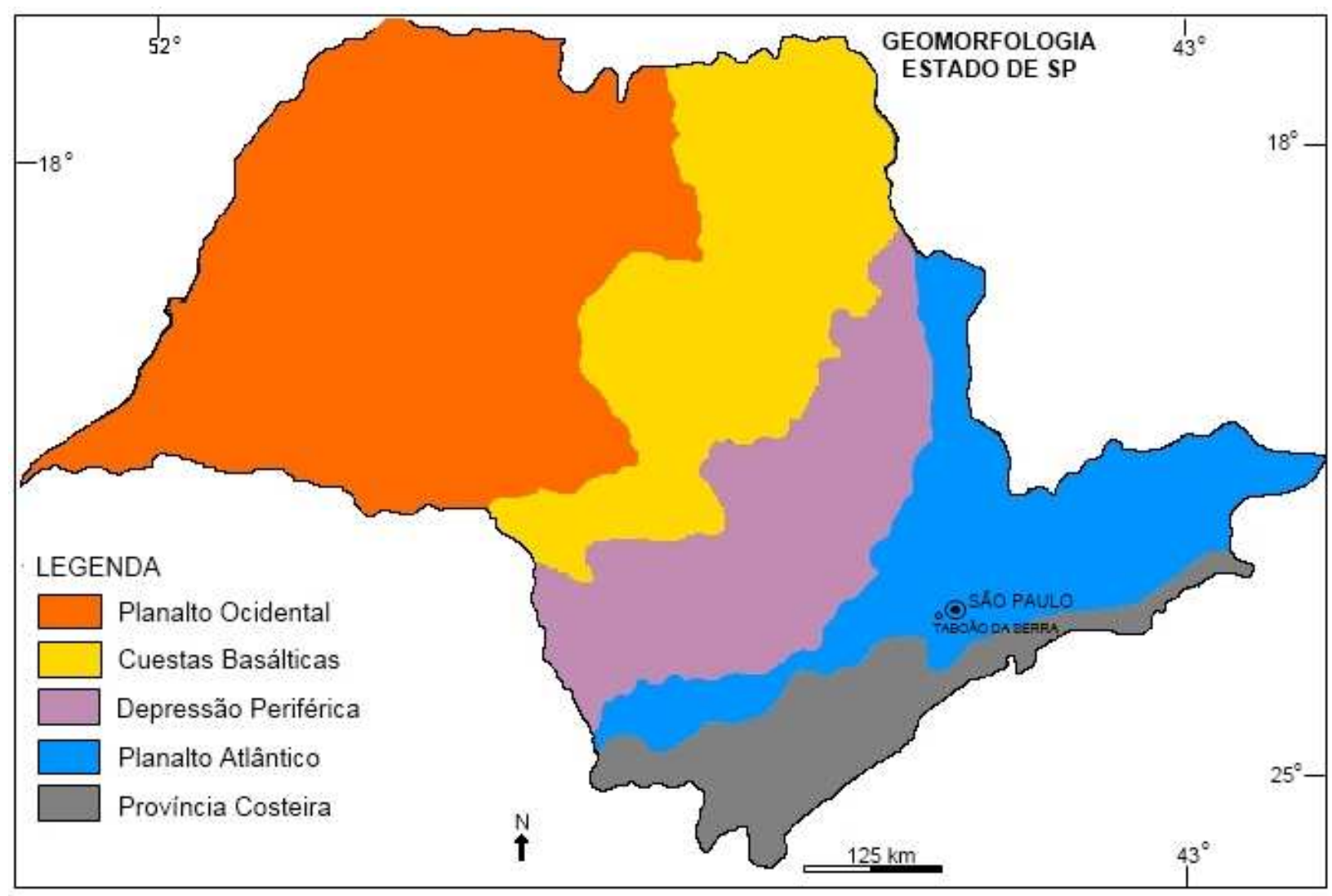

Fig.02 - Compartimentação do relevo do Estado de São Paulo. Fonte: Almeida (1964). 


\section{Compartimentação do Relevo Paulista}

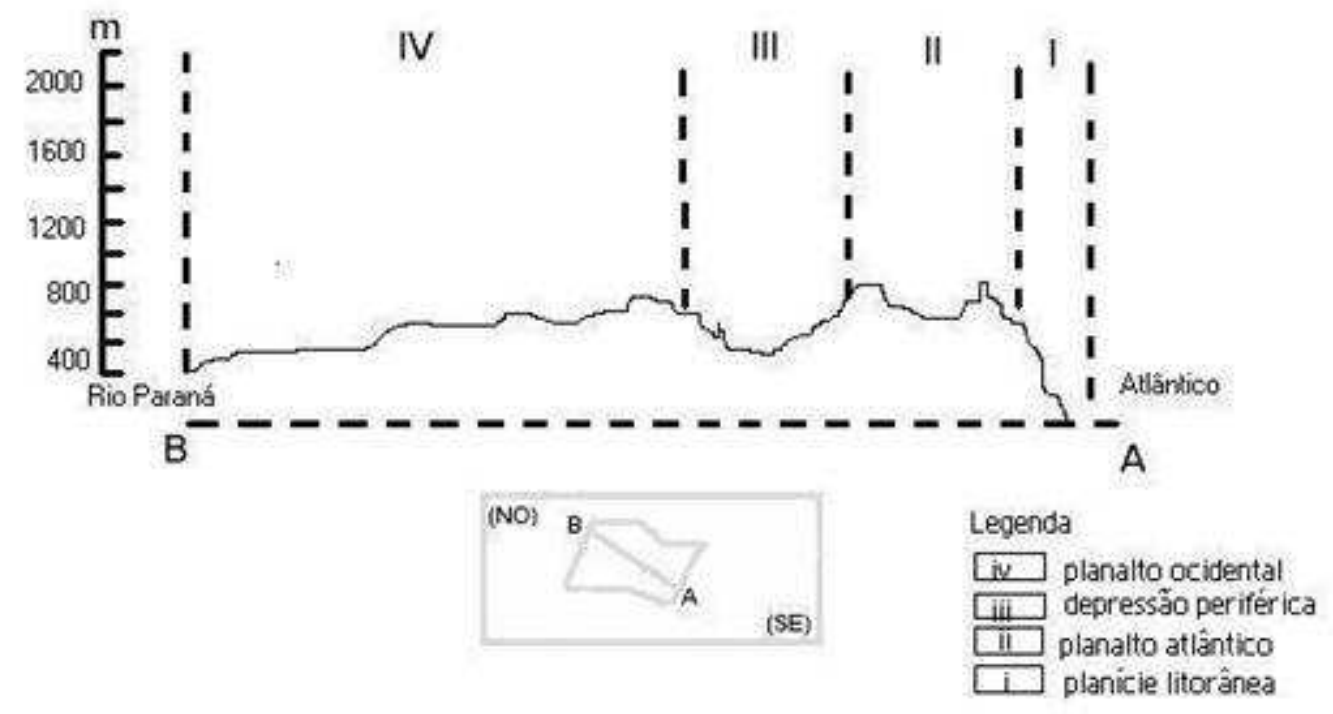

Fonte: Ab'Saber, IPT, 1981 Adaptado

Fig.03: Perfil da Compartimentação do Relevo Paulista, IPT, 1981. Adaptado.

A região metropolitana e seu sítio urbano, vem sendo investigado, com relação aos processos genéticos do relevo em trabalhos pioneiros desde a segunda metade do século $X X$, (AB'SABER, 1957; 1980; ALMEIDA, 1958; AZEVEDO, 1958; COUTINHO, 1980).

A expansão urbana a partir do início do século $X X$, ocupou terrenos além da Bacia Sedimentar, conurbando cidades do ABCD, como também no sentido noroeste e sudoeste. 
A expansão urbana, antes localizadas em terrenos sedimentares acaba por avançar para as áreas de terrenos précambrianos, terrenos estes que apresentam estrutura mais frágil com relação às áreas sedimentares. Essa característica aliada ao intenso uso do solo gerou ônus econômicos e sociais, associados à dinâmica do relevo onde os processos morfogenéticos agora se apresentam como mais um problema urbano.

O sítio urbano de Taboão da Serra, ocupa áreas assentadas sobre rebordos de características granítico-gnáissicas.

Seus controles estruturais no sentido SW-NE, sinaliza que houve um basculamento ou tectônica que afetou grandes áreas do rebordo ocidental da Bacia Paulistana, tendo o escoamento fluvial como nível de base o rio Pinheiros.

Levando-se em consideração as propriedades dos materiais e a morfodinâmica do relevo, elas estão diretamente ligadas atualmente ao tipo de uso que se aplicou sobre o assoalho.

Nos setores de falhas e juntas, elas tem como resultante extensas zonas de fraquezas estruturais e se refletem de maneira muito evidente no relevo. Os sistemas de juntas permitem que a rocha alterada in situ apresente-se como uma "pilha de tijolos", cujo equilíbrio é precário e se rompe com facilidade quando o homem intervém de maneira irrefletida, Abreu (1985).

Taboão da Serra não foge à regra, quando leva-se em consideração as características morfogenéticas dos rebordos da Bacia Sedimentar de São Paulo e a partir da década de 70, com a aceleração da urbanização sobre os terrenos pré-cambrianos, originou-se processos superficiais principalmente de erosão agressiva do tipo linear, ravinamentos que atingem de maneira mais contundente as construções com baixos padrões e que portanto são mais frágeis. 
O conceito de Georelevo de Kugler (1976, apud ABREU, 1985), exemplifica algumas particularidades do contato entre rochas, superfície e clima, o que gera uma interface complexa que pode ser visualizada no esquema proposto por Budel (1969) no que ele denominou de "RELIEFSPHERE" que viria a ser encarada como o GEORELEVO por Kugler (1976), (Fig.04).

As características litológicas de Taboão da Serra, localizada em área do rebordo da bacia sedimentar da RMSP, com seus planos de fraquezas estruturais e seus planos de juntas, aliadas às falhas, caracterizam um relevo particular em que são combinadas as características internas e externas.

O basculamento da área do município em direção ao Córrego Pirajussara (Fig. 05) e deste para o rio Pinheiros, portanto no sentido SW/NE, os tipos de solos dominantes e a fragmentação interna dos tipos litológicos combinavam-se anteriormente de uma forma, e com o incremento populacional e a urbanização, houve uma modificação das características de trocas e conversão de energia, principalmente pela retirada da vegetação. 


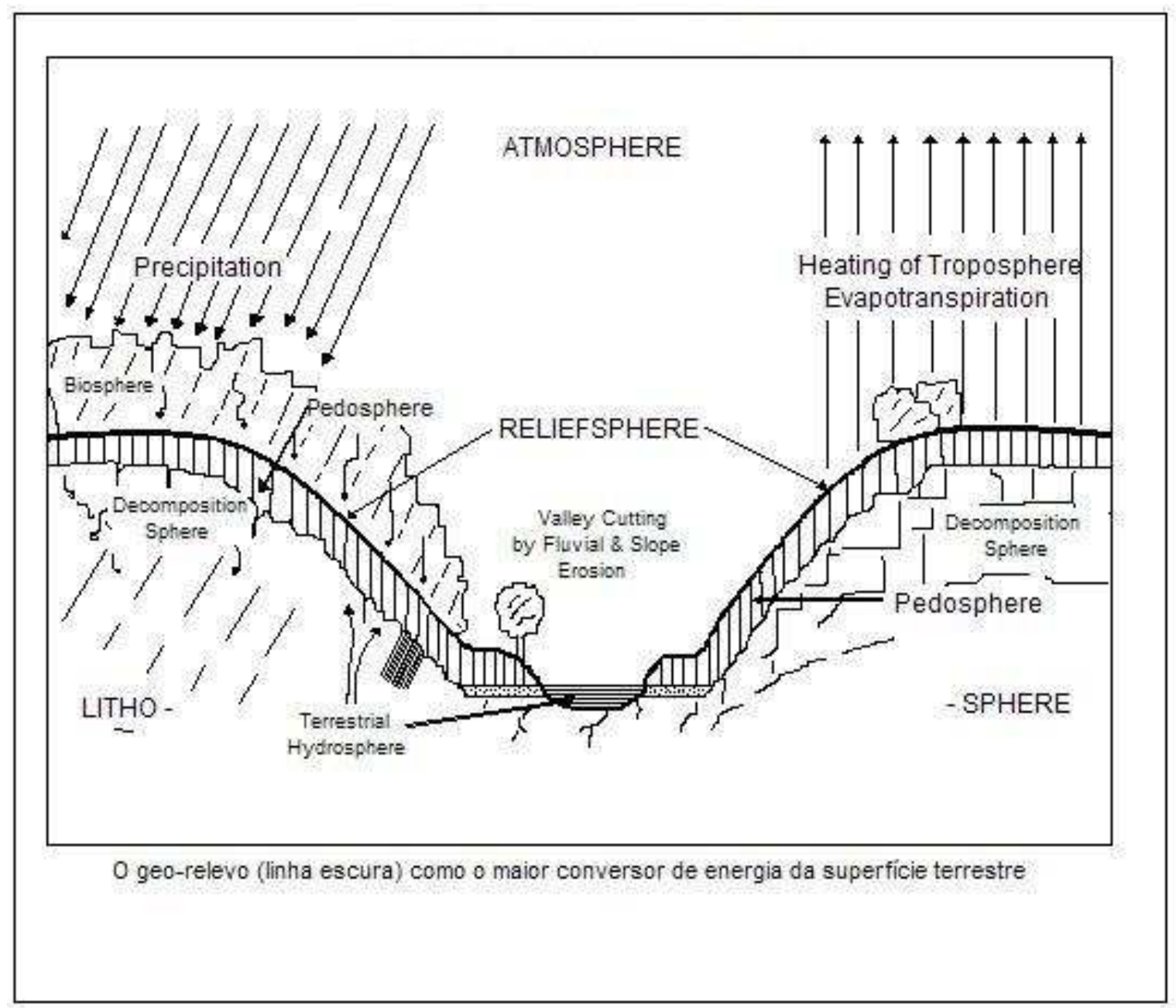

Fig.04: A esfera do relevo (RELIEFSPHERE) segundo Budel (1969)

$\mathrm{Na}$ área de estudo, para o que BUDEL chama de zona de contato (linha onde encontram-se o PEDO-RELEVO e o GEORELEVO), ou seja a resultante da adição de 3 fatores (vegetação, solo, clima) atualmente, há a modificação ou quase desaparecimento de parte da biosfera ou seja, conjunto de atributos naturais que protegem o solo, como por exemplo a cobertura vegetal. 


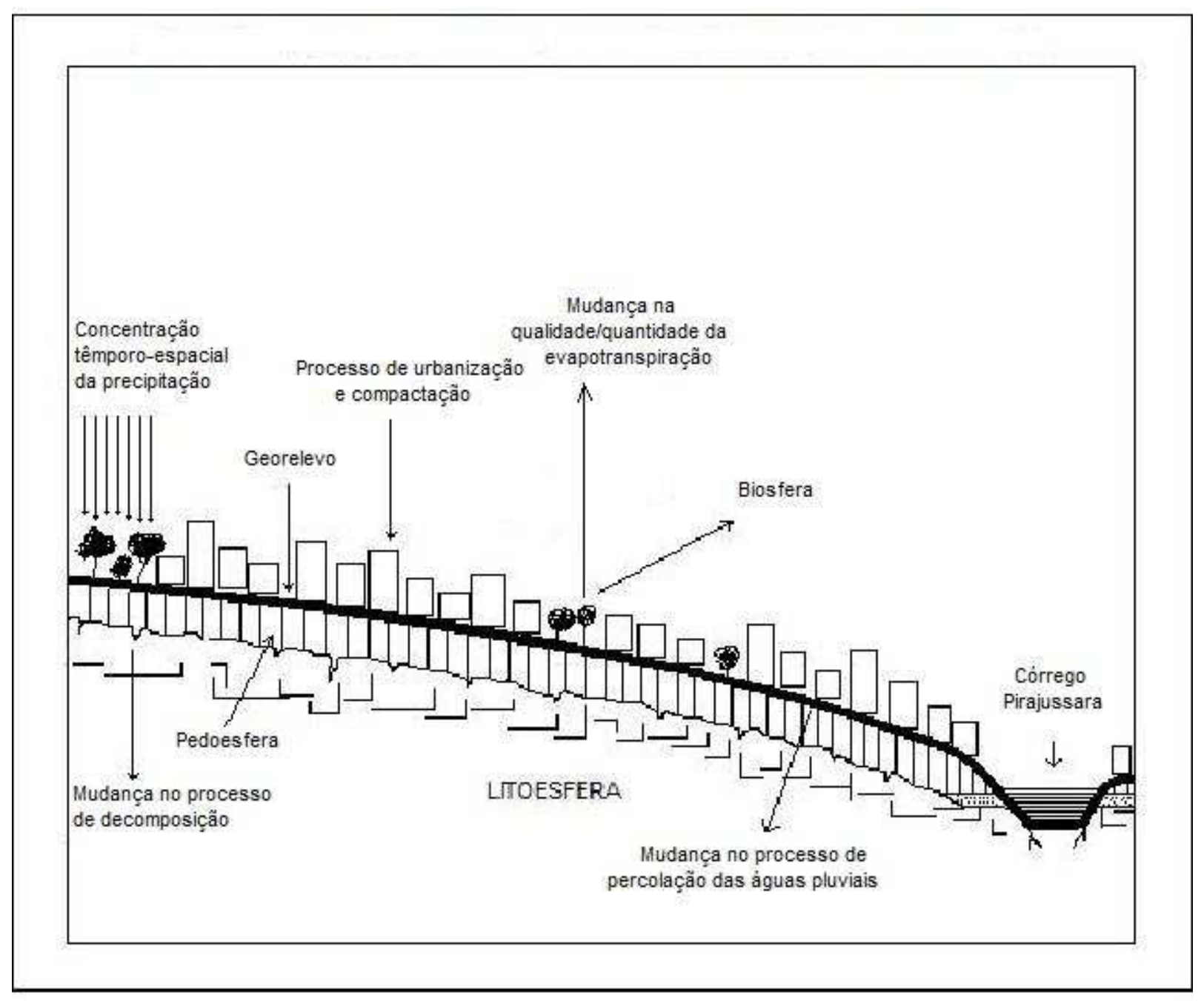

Fig.05: Modelo do georelevo de Taboão da Serra, adaptado a partir de Budel (1969) e Kugler (1976, apud Abreu, 1985)

A modificação desse atributo, contribuiu na modificação do regime de chuvas e na qualidade da evapotranspiração, mecanismos estes essenciais na manutenção do Geo-relevo. Daí denota-se que um dos resultados negativos mais visíveis são os constantes episódios de enchentes no município, onde há a potencialização da evapotranspiração combinada ao incremento da cobertura do solo.

Apesar de espacialmente a abrangência da Bacia Hidrográfica do córrego Poá ser maior do que a Bacia hidrográfica do córrego Pirajussara, e o córrego Poá ser um tributário do segundo, a ocupação urbana no território do município se mostra mais 
concentrada na Bacia do Pirajussara, que é caracterizada por encostas abruptas e terrenos ocupados pela população de baixa renda (Fig.06).

O local apresenta suas formas, escarpas e morrarias bastante trabalhadas pelas características do clima tropical, que tem como aspecto principal a torrencialidade das chuvas nos meses de verão, essa sazonalidade aliada às declividades elaboraram formas características e que se singularizam pela presença de muitas vertentes atualmente ocupadas.

Em se tratando de um planalto, recortados por serras, Ross (2006) enfatiza que este domínio geomorfológico associa-se ao cinturão orogênico do Atlântico, apresentando maior complexidade, e seu desenvolvimento vincula-se a vários ciclos de dobramentos, acompanhados também de vários metamorfismos regionais, falhamentos e extensas intrusões.

O município de Taboão insere-se de forma geral no domínio dos terrenos cristalinos que circundam a Bacia Sedimentar de São Paulo, nos seus setores, oeste, sul e leste, onde os níveis topográficos são mais elevados e os processos de evolução das vertentes são mais dinâmicos. Nesta região, as vertentes foram sendo elaboradas pelos processos atuantes do Quaternário. (Fotos 01 e 02). 
Fig.06: TABOÃO DA SERRA/SP-SUB-BACIAS HIDROGRÁFICAS

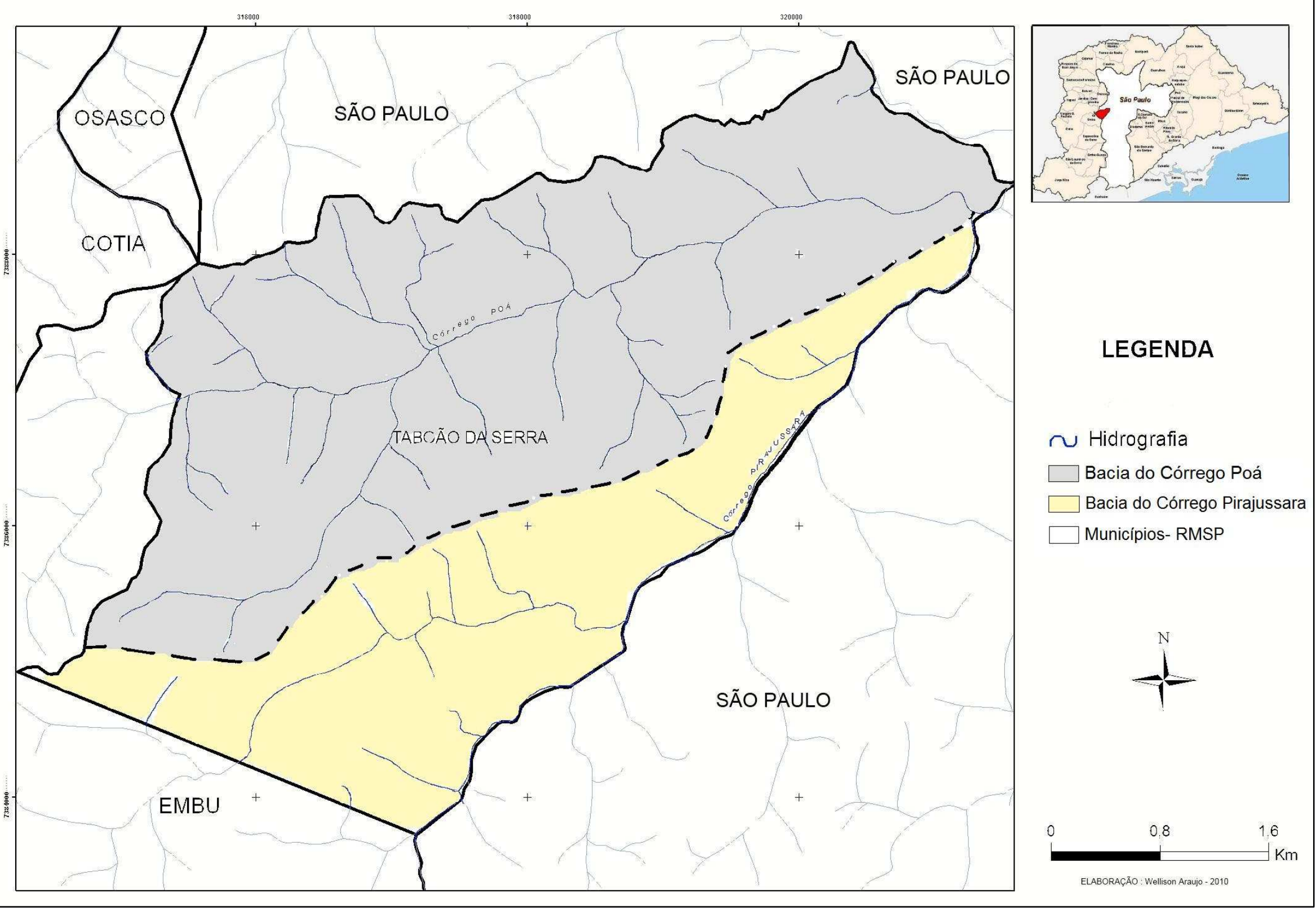




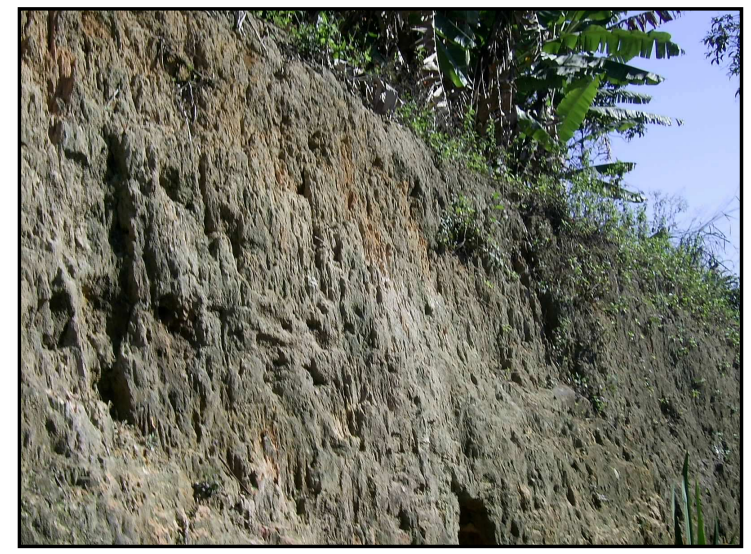

Foto 01 - Latossolo apresentando horizontes desenvolvidos.

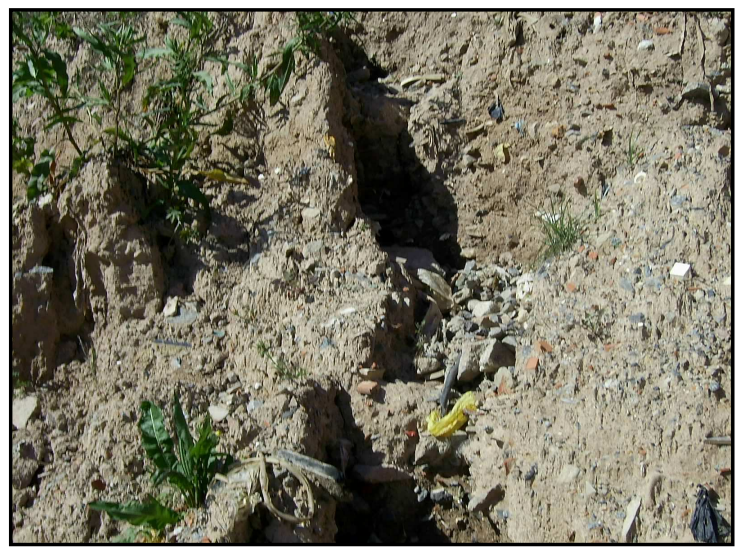

Foto 02 - Latossolo exposto e aparecimento de ravinas.

O relevo apresenta altitudes médias de $760 \mathrm{~m}$, sendo assim de acordo com a carta hipsométrica/MNT para o município, as elevações apresentam as seguintes características:

- Altitudes de 740 a $880 \mathrm{~m}$ : representa o nível de base da região, onde está a maior parte do Córrego Pirajussara e onde, localiza-se também as áreas de divisas entre o município e a cidade de São Paulo no seu setor sudoeste;

- Altitudes que variam de 760 a $780 m$ : ocupam a área central do município, representam in locus as áreas de vales e mais planas, abrangem aproximadamente metade da área onde está assentada a Rodovia Régis Bittencourt;

- Altitudes de 780 a $880 m$ : são representados pelos topos de morros e ocorrem em cerca de $50 \%$ da área de estudo, são morros alongados característicos de áreas de forte dissecação entremeados e trabalhados por córregos de pequena extensão;

- Altitudes de 800 a $820 \mathrm{~m}$ : Ocorrem em menor extensão, e são caracterizados pela presença de terrenos mais resistentes 
com formato alongado, localizam-se principalmente no setor norte do município na sua divisa com São Paulo.

\subsection{Condicionantes Climáticos}

A análise e interpretação dos diversos componentes do sistema natural requer, em primeira instância, a sua determinação e ação em escala espacial e temporal.

O ambiente urbano é resultado de um complexo que se desenvolve observando as características de três grandes estruturas: o plano físico, o biológico e o social Max.Sorre (1943). Na análise da Geografia Humana de Sorre, o mesmo destaca especial importância às características do clima sobre o homem, dentro da obra, destaca-se os fundamentos Biológicos dessa Geografia Humanística de Sorre (1943).

O autor analisa o fator clima e a sua relação com os elementos orgânicos, bem como os limites que este fator impõe ao homem (complexos climáticos), a relação entre o meio e enfatiza a idéia de associação entre o homem e o Meio, como interdependentes ou seja, estão associados imbuídos de uma característica de feedback.

Como resultante de um elemento climático (umidade relativa), a pluviosidade ganha importância dentro do pensamento de Sorre pois, é uma característica do Clima, sabendo-se que segundo o autor, o Clima é o resultado da "sucessão habitual dos tipos de tempo num determinado local da superfície terrestre".

Com a pluviosidade, a interpretação da sua forma e função, assim como da sua atuação no espaço-tempo, requer através dos gráficos uma posterior análise da junção processo/forma, o que resulta da capacidade do solo em absorver as águas pluviais ou, dos processos erosivos resultantes do impacto das chuvas sobre 
áreas densamentes povoadas ou desprovidas de cobertura vegetal.

\subsubsection{A expressão do Clima sobre o urbano: fenômeno das ilhas de calor}

Os fatores naturais, sobretudo aqueles ligados ao Clima ${ }^{2}$ são características marcantes dos domínios geoecológicos de certos ambientes.

Trabalhos pioneiros com relação às especificidades da formação da ilha de calor, tendo como campo de análise as cidades brasileiras tiveram início na década de 1970.

No Brasil os trabalhos que discutem a temática tem como principais pesquisadores (MONTEIRO, 1973,1976, 1977; TARIFA, 1975, TITARELLI, 1982; LOMBARDO, 1984, 1995)

Sobre as características do clima da metrópole paulistana e a conseqüente formação de ilhas de calor, Lombardo (1984) faz um balanço dos estudos com relação ao tema em nível mundial e elabora sua tese de doutoramento tendo como campo de pesquisa as características da formação do fenômeno na cidade de São Paulo.

As considerações sobre a formação da ilha de calor, tem como pano de fundo as alterações que sofrem os elementos como temperatura, umidade relativa, precipitação, nevoeiro, vento, que sofrem perturbações têmporo-espaciais em contato com a urbanização Landsberg (1956) apud (LOMBARDO 1984).

2 Segundo Ayoade (1988), clima refere-se às características da atmosfera, inferidas de observações contínuas durante um longo período. Abrangendo um maior número de dados do que as médias do tempo numa determinada área, o clima inclui considerações dos desvios em relação às médias, condições extremas, e a probabilidade de freqüência de ocorrência de determinadas condições do tempo. Assim, o clima apresenta uma generalização, enquanto o tempo lida com os eventos específicos. 


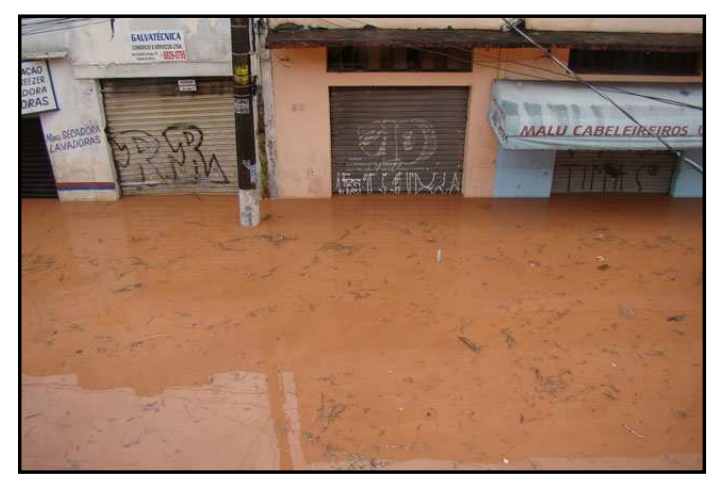

Foto-03 -Episódio de enchente em Taboão da Serra. 12/09. Av. Getulio Vargas.

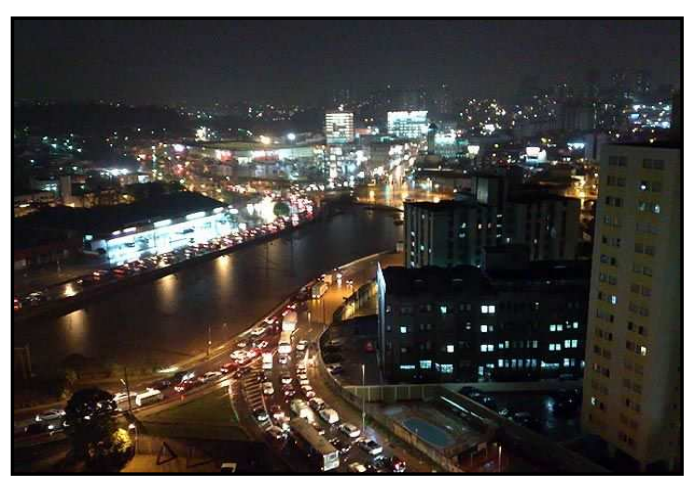

Foto 04 - Episódio de enchente em Taboão da Serra/SP. 10/09- Piscinão-

A análise da formação da ilha de calor, e de forma geral das características do clima urbano, tanto na metrópole quanto nas áreas vizinhas à mesma, englobando a RMSP e dentro dela o município de Taboão da Serra, tem como intuito avaliar a probabilidade da ocorrência da mesma anomalia num município que apresenta uso intenso do solo.

No nosso exemplo de estudo, elementos conjugados como: alta pluviosidade, uso intensivo do solo, condições de uso do sítio urbano (como exemplo temos a ocupação das áreas de várzeas eliminando a possibilidade de escoamento das águas pluviais e fluviais) geram a médio e longo prazo uma condição de saturação e desestruturação das condições sócio-ambientais levando ao estado de desequilíbrio constante.

O binômio densidade populacional e uso do solo revelam algumas peculiaridades. Segundo Oke (1987), a intensidade da ilha urbana de calor relaciona-se diretamente entre clima urbano e à densidade populacional, seu estudo relativo à esta problemática foi aplicado usando como campo de análise as cidades Européias e Norte-Americanas.O mesmo demonstra que, a geometria urbana, bem como as propriedades térmicas das superfícies tem maior influência que o vento e a densidade da população, tal trabalho, consolida o estudo da inter-relação entre 
clima urbano e uso e ocupação do solo.Segundo o autor existem duas camadas principais nas quais subdivide-se a atmosfera urbana:

Tabela 01 - Subdivisões da atmosfera urbana

\begin{tabular}{|c|c|}
\hline \multicolumn{2}{|c|}{ Subdivisões da atmosfera urbana } \\
\hline I- CANOPY LAYER & $\begin{array}{l}\text { - Camada limite do dossel } \\
\text { urbano - CDL: Estratificada } \\
\text { abaixo do nível dos telhados, } \\
\text { produzida pelos processos em } \\
\text { micro escala localizados nas } \\
\text { ruas, entre os prédios. }\end{array}$ \\
\hline II- URBAN BOUNDARY LAYER & $\begin{array}{l}\text { - Camada limite da influência } \\
\text { urbana - CLU: Estende-se } \\
\text { acima do nível dos telhados, } \\
\text { fenômeno localizado com } \\
\text { caracteríticas produzidas } \\
\text { pela natureza da superfície } \\
\text { urbana com rugosidade, } \\
\text { proporcionada pela presença } \\
\text { de prédios relativamente } \\
\text { altos, provocando uma } \\
\text { aerodinâmica particular. }\end{array}$ \\
\hline
\end{tabular}

Fonte: Oke, (1987)

Do ponto de vista das escalas de análise, de forma geral, as escalas climáticas urbanas (distância horizontal) podem ser classificadas, segundo Oke (2004) da seguinte forma: 
Tabela. 02: Escalas de análise climática

\begin{tabular}{|c|c|}
\hline \multicolumn{2}{|c|}{ Escalas de análise climática } \\
\hline 1-MACROCLIMÁTICA & 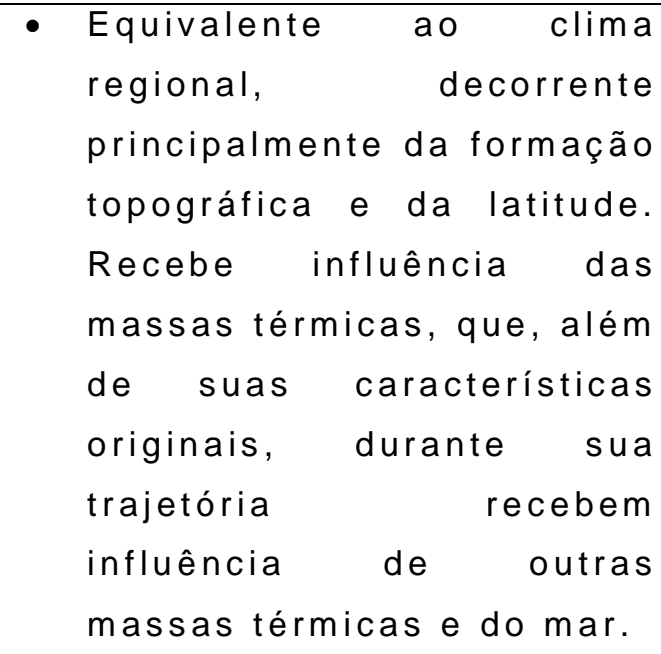 \\
\hline 2-MESOCLIMÁTICA & 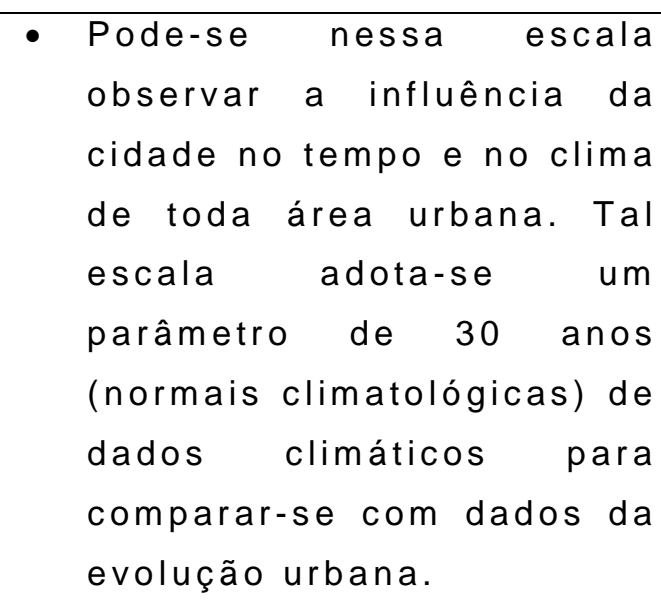 \\
\hline 3-LOCAL & $\begin{array}{l}\text { - } \text { Recebe influência direta } \\
\text { dos efeitos da paisagem } \\
\text { sobre o clima, tal qual a } \\
\text { topografia, excluindo porém } \\
\text { os efeitos do microclima. } \\
\text { Nas cidades isto equivale } \\
\text { ao impacto das vizinhanças } \\
\text { com tipos similares de } \\
\text { desenvolvimento urbano tal } \\
\text { qual, a cobertura da } \\
\text { superfície, tamanho e } \\
\text { espaçamento das }\end{array}$ \\
\hline
\end{tabular}




\begin{tabular}{|c|c|}
\hline & construções e atividades). \\
\hline 4-MICROCLIMÁTICA & 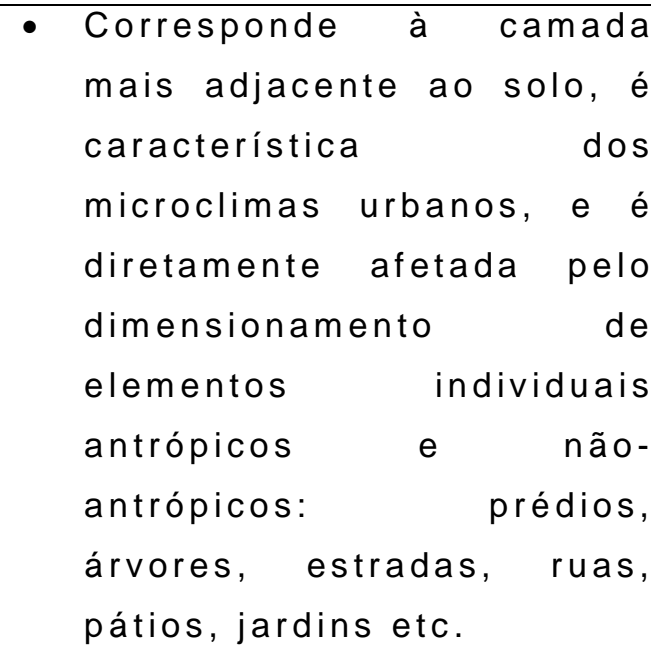 \\
\hline
\end{tabular}

Fonte: OKE, (2004)

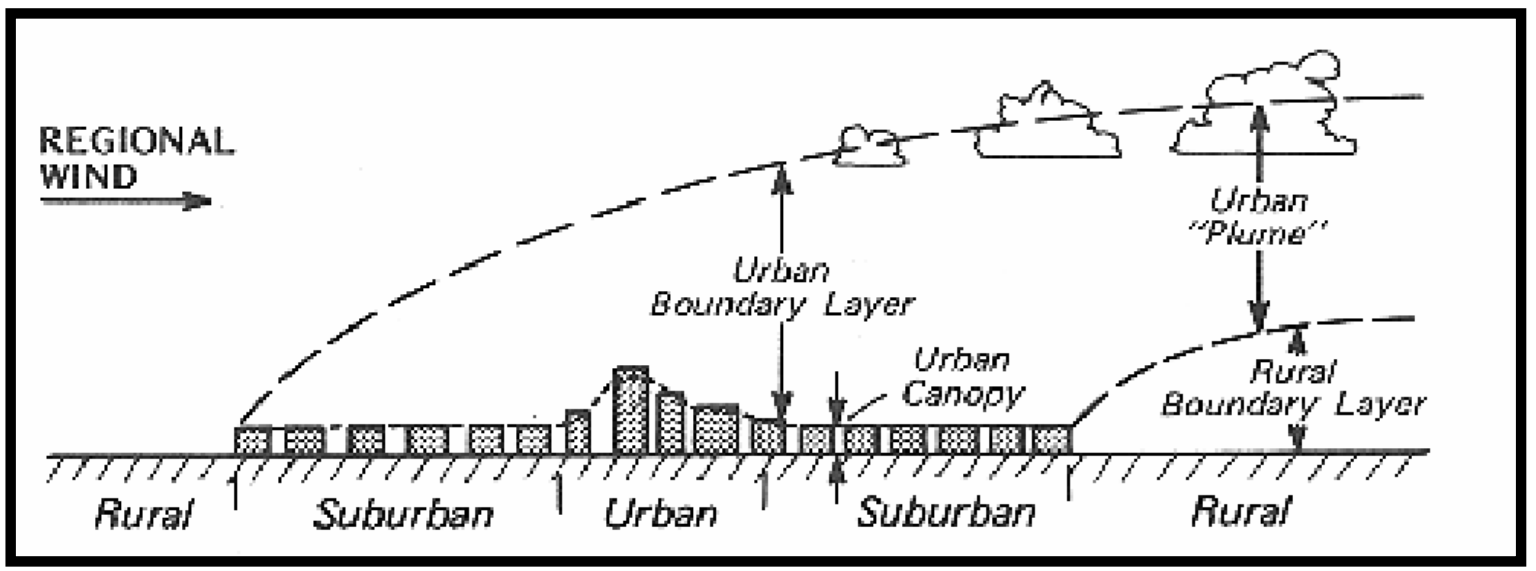

Fig..07: Representação esquemática da atmosfera urbana: camada limite da influência urbana (CLU); camada limite do dossel urbano (CLD); camada limite rural (CLR).

Fonte: Oke, 2004 .

Em nosso país, as pesquisas teóricas que resultam em modelos sobre clima urbano, desenvolveram-se principalmente durante as décadas de 1960 e 1970. Tarifa et all (2001) afirma que a maior parte dos trabalhos desenvolvidos na área urbana nesta época, concentrava-se em avaliar os aspectos referentes à ocorrência de chuvas e poluição do ar. 
Tal aspecto não levava em consideração que a vida cotidiana de seus habitantes sofresse algum impacto, resultante principalmente da qualidade do ar e do conforto térmico. A mudança da ótica para analisar tais problemas seria necessária pois, há períodos no dia em que as atividades da população local pesam mais que os aspectos do meio físico para definir por exemplo, a temperatura em uma região específica num determinado horário. As unidades climáticas da RMSP, são uma classificação na qual são demarcadas as unidades climáticas naturais e as unidades climáticas urbanas. Numa segunda análise, o esboço do mapa dessa classificação para Taboão da Serra, traz enquantozona de classificação:

Tabela.03- Unidades climáticas naturais do município de São Paulo e adjacências

\begin{tabular}{|c|c|}
\hline \multicolumn{2}{|c|}{ Município de São Paulo - Unidades Climáticas } \\
\hline $\begin{array}{c}\text { Unidades climáticas } \\
\text { naturais }\end{array}$ & $\begin{array}{c}\text { Unidades climáticas } \\
\text { urbanas }\end{array}$ \\
\hline $\begin{array}{l}\text { I-Clima tropical de altitude do } \\
\text { planalto paulistano }\end{array}$ & I-Unidade climática central \\
\hline $\begin{array}{llll}\text { II-Clima tropical } & \text { úmido } & \text { da } \\
\text { Cantareira-Jaraguá } & & \end{array}$ & II-Unidade climática da perfiferia \\
\hline $\begin{array}{l}\text { Ill-Clima tropical úmido do alto } \\
\text { Juqueri }\end{array}$ & $\begin{array}{l}\text { Ill-Unidade climática do urbano } \\
\text { fragmentado }\end{array}$ \\
\hline $\begin{array}{l}\text { IV-clima tropical sub-oceânico super- } \\
\text { úmido do reverso do planalto } \\
\text { atlântico }\end{array}$ & IV-Unidade climática não-urbana \\
\hline $\begin{array}{l}\text { V-Clima tropical oceânico super- } \\
\text { úmido da fachada oriental do } \\
\text { planalto atlântico }\end{array}$ & \\
\hline
\end{tabular}

Fonte - Tarifa, (2001)

Elaboracão: Arauio.W. 2009. 
Com base na divisão das unidades climáticas para o Estado, segundo Tarifa (2001), Para o município de Taboão da Serra pode-se considerar:

a) Unidades Climáticas Naturais: classificado como clima tropical de altitude do planalto paulistano (I);

b) Unidades Climáticas Urbanas: Unidade climática central (I);

c) Unidades Climáticas Urbanas: Unidade climática da periferia (II).

Apesar da aparente não-classificação das unidades periféricas, caracterizadas pela grande RMSP, percebe-se que 0 alcance da classificação vai além das divisas municipais, já que, o fenômeno natural e mesmo aquele antropizado não leva em consideração divisas municipais demarcadas politicamente, isso leva a crer que a abrangência por exemplo, do domínio das unidades climáticas naturais do município de São Paulo abrange também a área de Taboão da Serra (Tab. 03).

Para Monteiro (1976), a cidade gera um clima próprio (clima urbano), resultante da interferência de todos os fatores que se processam sobre a camada de limite urbano e que agem no sentido de alterar o clima em escala local. Seus efeitos mais diretos são percebidos pela população através de manifestações ligadas ao conforto térmico, à qualidade do ar, aos impactos pluviais e a outras manifestações capazes de desorganizar a vida da cidade e deteriorar a qualidade de vida de seus habitantes.

A definição do ritmo climático e a expressão quantitativa dos elementos se complementam, formando um importante binômio. Segundo Monteiro (1973) a organização dos fatos climáticos não pode estar dissociada do seu aspecto causal, pois, a idéia de coerência interna é essencial à organização dos espaços climáticos. 
Tal coerência é caracterizada pelo ritmo $^{3}$ e que se dá pela solidariedade entre os atributos do clima, ou como cita o próprio autor: "...a solidariedade no sistema expresso pela região climática seria dada pelo dinamismo do espaço-tempo definido num campo-presente que é o segmento temporal, expresso em momentos que, embora sejam extremamente mutantes guardem uma lógica de ritmo, que se projeta sobre o espaço físico e estrutura a unidade de organização..." (MONTEIRO, 1973).

As manifestações temporais do clima estão ligadas aos mecanismos dinâmicos da circulação atmosférica e se manifestam no espaço pelos atributos. Os mecanismos da circulação atmosférica implicam no modo de entrada de energia atmosférica no interior do sistema e contém a idéia de processo Aouad (1978).

\subsection{Embasamento Geológico}

Os estudos pré-existentes, atestam a partir da carta geológica para a RMSP (COUTINHO, 1980), que a área do município de Taboão da Serra insere-se em contexto geológico onde são predominantes as rochas do embasamento cristalino.

Estas em contato com sedimentos do período terciárioquaternário, estão por sua vez inseridos na Bacia Sedimentar de São Paulo, onde também ocorrem sedimentos aluvionares quaternários (ALMEIDA, 1964).

Toda a extensão territorial do município de Taboão da Serra, faz parte do domínio dos Planaltos do Atlântico-leste-sudeste. As rochas do embasamento cristalino, são representadas pela ocorrência de migmatitos e gnaisses graníticos, ocorrendo em toda sua extensão..

3 Tal aspecto pode ser evidenciado pela presença da climatologia dinâmica que é o estudo dos movimentos atmosféricos em várias escalas, particularmente na circulação geral da atmosfera. 
Seguindo a constatação dos trabalhos de mapeamento da morfoestrutura da superfície do Brasil, oriundas de Ross (1990) e (1995), as características litológicas da região, são representadas na sua maior parte pelos Planaltos em cinturões orogênicos.

Segundo o autor, os planaltos ocorrem nas faixas de orogenia antiga e que correspondem a relevos residuais sustentados por litologias diversas, sendo na sua maioria litologias do tipo metamórficas, que se associam às rochas intrusivas. Nesses planaltos, situam-se inúmeras serras, que estão comumente associadas aos resíduos de estruturas com características de dobramentos, que foram constantemente alvo dos processos erosivos e que agora encontram-se ocupadas pela cobertura artificial do solo.

Tal fato, é representado localmente principalmente na porção sudoeste do município, onde localizam-se as áreas mais densamente povoadas e com construções de baixo padrão.

Esta característica ocorre juntamente com a ocupação dos terrenos mais íngremes e com o desmatamento dessas encostas, representando uma potencialização dos fatores de riscos aliados à alta pluviosidade, declividade e ocupação desordenada.

\subsection{Caracterização Pedológica}

Segundo Lepsch (2002), o solo é um objeto completo de estudos básicos-aplicados, onde usa-se método científico de induções e deduções sucessivas para sua classificação. Sendo assim, o solo é o resultado de uma coleção de corpos naturais dinâmicos, que contém matéria viva, e é resultante da ação do clima e da biosfera sobre a rocha, cuja a transformação em solo se realiza durante certo tempo e é influenciada pelo tipo de relevo. 
No meio urbano, a caracterização e o estudo dos solos, tornam-se importantes do ponto de vista da sua capacidade de suportar a ocupação pois, a partir de características como (textura, estrutura, porosidade, permeabilidade, profundidade etc.), verifica-se por exemplo sua susceptibilidade à erosão.

Desta forma, as pesquisas, mesmo que em meio urbano, que levem em consideração parâmetros como fragilidade ambiental tem grande relevância ao analisar a distribuição dos solos e sua menor ou maior susceptibilidade à erosão.

NO PLANALTO ATLÂNTICO, o modelado dominante são representados pelos "Mares de morros" definidos por Ab'Saber (1969). Nessa unidade, as litologias predominantes são as rochas , micaxistos, filitos, rochas carbonáticas e algumas instrusivas como granitos e sienitos. Tais características contribuíram para o aparecimento de solos dos tipos latossolos vermelho-amarelos distróficos, podzólicos, vermelho-amarelos distróficos (argilosos vermelho-amarelos), os cambissolos hálicos, neossolos litólicos e afloramentos rochosos.

Os solos de certa maneira, reproduzem as condições litológicas da região. Segundo Ross (2006), de uma forma geral, os tipos de solos que são mais comuns no domínio do Planalto Atlântico, se caracterizam por serem resultantes de rochas matter como os gnaisses, migmatitos, granitos etc.

Os afloramentos rochosos são constantemente trabalhados pela erosão pluvial, desse trabalho resultam os solos latossolos vermelho-amarelos. Neste contexto, constata-se que os latossolos vermelho-amarelos constituem-se no tipo pedológico comum nas áreas de escarpas na cidade de Taboão da Serra.

Segundo a classificação do IAC (INSTITUTO AGRONÔMICO DE CAMPINAS, 1999 E EMBRAPA SOLOS, 1999), no estado 
predominam os grandes grupos de solos Latossolos e os Argissolos (antigos Podzólicos).

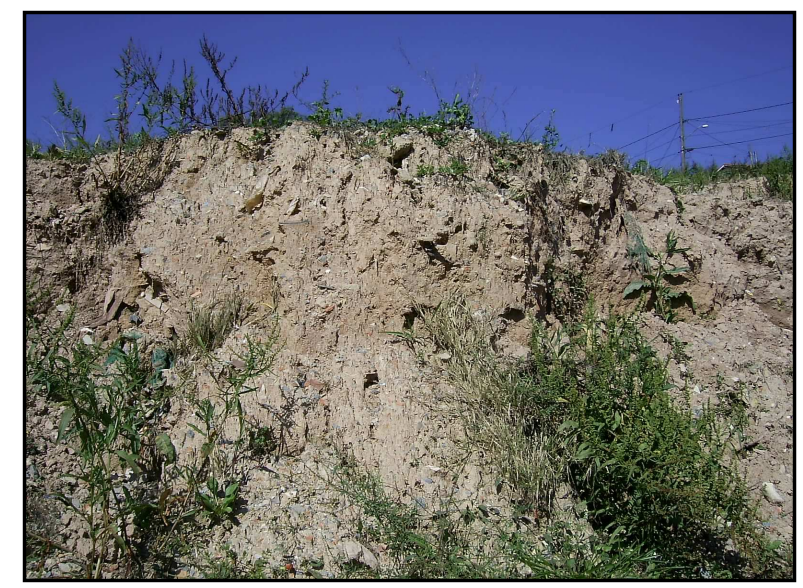

Foto 05 - Recorte de talude e latossolo. Vila Indiana.

No município de Taboão da Serra, há a predominância dos latossolos vermelho-amarelos principalmente abrangendo porções a sudoeste compreendendo a maioria dos bairros.

Segundo a escala de vulnerabilidade/estabilidade dos solos, obedecendo a proposição teórica de Crepani et all (2001) as classes de solos para o município de Taboão apresentam características marcantes. Os latossolos Vermelho-Amarelos apresentam um grau de vulnerabilidade (1), embora esta característica seja a de um solo que apresenta perfis estruturados, nota-se que as condições de uso da terra (recorte de taludes) e ocupação de encostas íngremes, provocam a desestabilização do solo e dessas encostas. 


\subsection{Processo Histórico de Ocupação da Área}

O município de Taboão da Serra/SP, teve seu surgimento de forma espontânea, como era comum entre as cidades brasileiras que surgiram no século XX, exceto aquelas planejadas.

Taboão da Serra tem seu início por volta do ano de 1910, quando uma localidade (vilarejo) de nome Vila Poá foi surgindo às margens dos córregos Poá e Pirajussara. Inicialmente existiam poucas construções, sendo o mais comum as chácaras, que mantinham uma agricultura de subsistência como a produção de batatas, cenouras, mandioca além de pomares e parreirais.

Na mesma época, a população residente no local começou a crescer, sendo comum a presença da igreja católica e dos padres que aproveitavam a tranqüilidade da região para a instalação de conventos, sendo assim, essa tranqüilidade foi aproveitada para a instalação de colônia de férias católicas, onde os sacerdotes passavam também fins de semana, desenvolviam atividades esportivas e culturais.

Pela localização privilegiada e clima ameno, muitas famílias começaram a se instalar em Taboão. No início, ainda na década de 20 e 30, a Vila Poá era muito distante do centro paulistano. Não existiam linhas de ônibus e os moradores que precisavam ir até o centro (o mais comum era o deslocamento até o Largo do Arouche), por exemplo, precisavam ir à pé até o Butantã, de onde partia uma vez por dia uma jardineira levando os moradores da região até o centro da capital paulista.

O nome da cidade tem sua origem duvidosa, mas duas versões são mais conhecidas. Foi por volta de 1940 que o nome "Taboão" foi pela primeira vez usado para designar a cidade. Atualmente onde se localiza o Grupo Hospitalar Family, onde hoje é o Largo do Taboão, segundo algumas versões, era utilizada uma 
"tábua" muito grande para se chegar ao outro lado do córrego Pirajussara, já em terras paulistanas (Distrito do Butantã),

Os produtores da região, inclusive do Pirajussara, iam vender seus produtos na capital e marcavam de se encontrar para ir até o mercado. O "Taboão" era o ponto de encontro. Nesta época, a Vila Poá ainda pertencia a Itapecerica da Serra.

Em meados da década de 1950, a população residente local já alcançava aproximadamente cinco mil moradores, e em 1953 a aglomeração já era subdistrito de Itapecerica da Serra. Nesta época houve o início das manifestações para a emancipação do distrito. Taboão virou cidade no dia $1^{\circ}$ de janeiro de 1959. 
Taboão da Serra ontem:

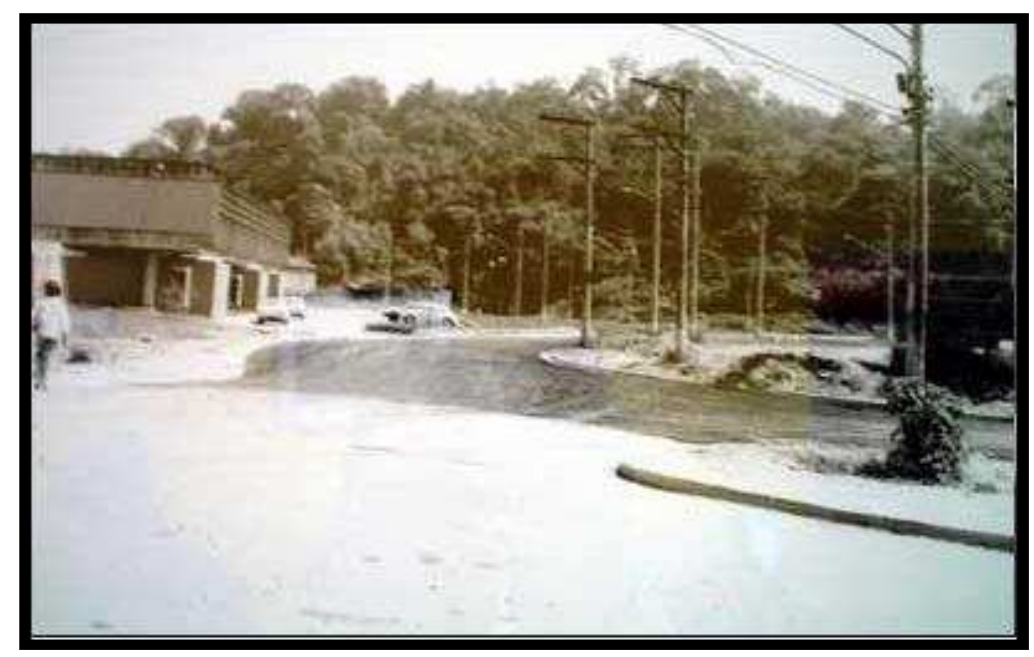

Foto 06 - Taboão da Serra em 1975-Área onde hoje encontra-se instalada a prefeitura.

Taboão da Serra hoje:



Foto 07-Centro de Taboão da Serra em 2008. 
O núcleo urbano do município atualmente apresenta-se adensado no entorno da rodovia Régis Bittencourt (Foto 07), o que demonstra que Taboão da Serra desenvolveu-se em dependência desta importante rodovia federal (BR 116 no seu trecho sul) dado o seu movimento tanto de cargas quanto da importância da ligação entre o sul do país e a metrópole paulistana. 
4. EMBASAMENTO TEÓRICO-CONCEITUAL 


\subsection{Fundamentação Teórica}

O conhecimento geomorfológico organizado nas Faculdades de Ensino Superior parece estar distante da realidade da maioria da população, que por vezes desconhecem até o próprio vocábulo. Como cita Viers (1973 p.15), a geografia é a ciência da organização do espaço terrestre, e é a partir dessa organização que a ciência tem como necessidade a compartimentação do conhecimento, afim de explicar, partindo do particular para o todo (Teoria dos Sistemas).

A utilização de termos teóricos delimita o universo de pesquisa de cada profissional, o qual deveria trabalhar não somente para manter o "status quo" de sua área de estudo, mas, e principalmente, para contribuir na melhoria das condições sociais da população. O dado econômico nas sociedades capitalistas de mercado está cada vez mais importante, pois o mesmo tende a ser o cerne dinamizador de novas práticas sociais que irão resultar em outras formas também sociais, mas de origem econômica.

No atual estágio de desenvolvimento da sociedade, o espaço geográfico está sendo organizado de forma diferente nas várias regiões e, conforme as circunstâncias, dentro de uma mesma região. Segundo Andrade (1986) a especialização econômica dita o modelo de ocupação territorial em cada espaço, extra e intraregional.

De acordo com a idéia exposta acima em Taboão da Serra SP a questão espacial está sendo cada vez mais privilegiada pois, os meios de transportes ainda não são suficientes para atender a demanda, provocando a curto e longo prazo uma densificação populacional, isto vem ocorrendo na área mais industrializada da cidade.

A metodologia geossistêmica (SOTCHAVA, 1962) é a base da nossa pesquisa pois, o estudo das organizações espaciais 
englobam a complexidade e analisa a estruturação, o funcionamento e a dinâmica dos elementos do geossistema. $O$ conceito de geossistema torna-se mais abrangente do ponto de vista da complexidade e da abordagem espacial de todos os fatores e processos que existem no planeta incorporando também os sistemas socioeconômicos, que irão delimitar a forma de fluxos de bens e serviços e a forma de apropriação do meio-ambiente.

Segundo a representação espacial dos fenômenos e processos geomorfológicos, leva-se em consideração neste trabalho a noção de escalas de grandeza enunciadas por Tricart (1967) no seu tratado "Principes e Méthodes de la Geomorphologie", pois a noção espacial de grandeza torna-se essencial na delimitação da área de estudo no intuito de traçar parâmetros para atingir o objetivo final da pesquisa.

Desta forma o objeto de estudo se insere no elemento de $5^{\text {a }}$ grandeza, onde são caracterizados elementos geomorfológicos locais, e é delimitado pela escala cartográfica de 1:10.000. Tal escala será trabalhada inserindo-a num SIG ou num BDG (Banco de Dados Geográfico) que resultará em vários documentos cartográficos.

O Sistema de Informação Geográfica é na verdade um Banco de Dados Geográfico que está ligado ao conceito de geotecnologias.

A história do uso de computadores para mapeamento e análise espacial vem mostrando um desenvolvimento paralelo na automação da aquisição de dados, análise de dados e apresentação de informações em diferentes modelos de arquivos (BURROUGH,1998).

Estes arquivos resultantes do mapeamento cadastral e topográfico, levantamentos da cartografia temática, da engenharia civil, da geografia, dos estudos matemáticos de variações espaciais, dos levantamentos da ciência do solo, dos 
levantamentos fotogramétricos, do planejamento urbano e rural, utilizam sistemas de rede e sensoriamento remoto e análise de imagens (BURROUGH,1998).

Utilizaremos juntamente com o estudo geomorfológico a base geotecnológica para a construção de modelos (cartas) de diagnóstico e prognose para o local em avaliação. Parte-se, portanto, do estudo integrado não só da paisagem como também da união teoria e prática (meio-ambiente e novas tecnologias).

Os riscos ambientais, aqui são discutidos levando em consideração a instalação da "Vulnerabilidade" enquanto condição que por vezes pode conter uma fragilidade, como no caso das áreas urbanas adensadas de forma desorganizada mas, podem não apresentar tais riscos.

Godard (1988) e Nyèrges (1997), apresentam uma discussão acerca do risco versus vulnerabilidade como sendo uma dependente da outra mas, necessariamente uma pode não conter a outra, ou seja, há diferenças e compatibilidades entre os dois termos.

L'association des deux termes n'est pás sans offrir, de prime abord, quelque apparence de paradoxe. II n'est rien en effect de plus construît, de plus pense, sinom maîtrisé, que la ville. Et rien de plus étranger à la volontée humaine, de plus rebelle au controle dês sociétés que la manifestation du risque naturel (FAUGÈRES, 1995).

Segundo o autor citado acima, a associação dos dois termos é paradoxal, mas no entanto, os riscos urbanos são construídos com a ocupação do meio natural, passando de um risco ambiental à um risco urbano. Nos sistemas ambientais urbanos, a vulnerabilidade é na maioria das vezes transformadas passando à categoria de riscos, desta forma a vulnerabilidade num sítio urbano não se explica só pela condição natural do sítio, mas também pelos sistemas ambientais atuantes (processos) e principalmente pelo tipo de ocupação antrópica dada ao local. 
Mesmo com tais premissas, a atividade humana e urbana incessante, transmite um sentimento de imunidade com relação ao meio em que habitam, fazendo com que a população fique exposta a tais riscos à que estão predispostos de acordo com o local ocupado, ocorrendo então uma sensação de segurança irreal, ante as calamidades sazonais que podem ser naturais ou dinamizadas pela ocupação indiscriminada.

Embora os serviços das cidades atendem em parte às necessidades de seus habitantes, o progressivo acréscimo de população que é uma das principais características dos países em desenvolvimento extrapola tal expectativa.

Ce sentiment de relative immunité urbaine semble ajourd'hui voler em éclats, aussi bien dans lê Nord que dans le Sud de la planète. Dans de villes qui ressemble une part de plus en plus important d'une population mondiale em croissance três rapide, on voit lê tissu urbaine se densifier, lês infrastructures s'alourdir. Les sites primitifs sont dèbodès lês espaces environments profondément transformes par l'aménagement, lês conditions de fonctionnement des géosystèmes se modifient, le valeur des biens exposés s'accroît (FAUGÈRES, 1995).

Desta forma fica evidente que na maioria dos países desenvolvidos, em sua maior parte localizados no hemisfério Norte, há um crescimento populacional quase que estabilizado, e em muitos havendo até decréscimo populacional, mas esta população como em todo mundo não se preocupa (condicionante psicológico) com a possibilidade da ocorrência de eventos (riscos) não diferenciando-se assim da maioria dos países em desenvolvimento, no que diz respeito à sensação de estarem ou não sujeitos aos riscos.

Quando analisamos os fatores ambientais que causam vulnerabilidade em alguns locais, acabamos também associando os mesmos aos riscos ambientais, embora haja uma relação intrínseca entre os dois termos, chega-se à conclusão que existe um risco em habitá-lo. 


\subsection{Embasamento Conceitual Ambiental}

A discussão acerca da abordagem geossistêmica neste trabalho, leva em consideração parâmetros como risco, vulnerabilidade, fluxo de energia, movimentos de massa e outros que implicam diretamente na proposta de trabalho. O foco Geossistêmico no entanto, é o cerne principal que embasa toda a discussão e a finalidade do tema.

As mudanças ocasionadas no ambiente como efeitos da ação antrópica refletem as alterações significativas no equilíbrio dos sistemas naturais, principalmente no decorrer das últimas décadas, com o aumento da população e do processo de urbanização, onde intensificaram-se os impactos da interferência humana na paisagem. Estes processos transformaram toda a estrutura ecológica e social, provocando, assim,uma maior fragilidade e vulnerabilidade do ambiente.

A Teoria Geral dos Sistemas, pode ser compreendida como uma filosofia e teoria científica que tem como base a hierarquização da Natureza, que é trabalhada como um sistema aberto, que tem uma complexidade organizacional crescente Naveh et all (1998,p.89). Segundo Christofoletti (1999, pg.04) o vocábulo sistema, representando conjunto organizado de elementos e de interações entre os mesmos, possui uso antigo e difuso no conhecimento científico (como exemplo sistema solar).

Todavia, a preocupação em se realizar abordagem sistêmica conceitual e analítica rigorosa surgiu explicitamente na Biologia teorética, na década de 1930. O conceito de sistemas foi introduzido na Geomorfologia por Chorley em 1962, e a pormenorização das características dos sistemas ambientais foram abordados por diversos autores como Christofoletti (1979), Strahler (1980), Haggett (1985) e Scheidegger (1991). 
Um sistema é um conjunto estruturado de objetos e ou atributos, esses objetos e atributos consistem de componentes ou variáveis (isto é, fenômenos que são passíveis de assumir magnitudes variáveis) que exibem relações discerníveis um com os outros e operam conjuntamente como um todo complexo, de acordo com determinado padrão, Chorley \& Kennedy (1971).

Dessa forma os padrões naturais de transformação (desenvolvimento dos sistemas ambientais urbanos) são alterados drasticamente pela intensa atividade urbana, o que denota uma necessidade de num estudo científico para aprimorar a metodologia a ser utilizada para diagnosticar e dar direcionamentos para o saneamento dessa problemática.

Do ponto de vista conceitual, a dinâmica natural é exercida sobre uma base física (a superfície terrestre) e que é por vezes desregulada pela intensa ação antrópica, desta forma é necessário compreendermos a dinâmica natural e aquela ocorrida após uma ação humana sobre a paisagem. O termo paisagem torna-se também um conceito chave no nosso estudo dentro da diversidade conceitual em que se encontra:

\begin{abstract}
A paisagem não é a simples adição de elementos geográficos disparatados. É uma determinada porção do espaço, resultado da combinação dinâmica, portanto instável, de elementos físicos, biológicos e antrópicos que, reagindo dialeticamente uns sobre os outros, fazem da paisagem um conjunto único e indissociável em perpétua evolução (BERTRAND, 1971,p.02).
\end{abstract}

A paisagem também pode ser considerada integrante de um sistema, com cada uma de suas unidades relacionadas umas às outras, possuindo um desenvolvimento próprio, ou seja, uma evolução que the é própria e que as leva a experimentar mudanças em sua estrutura (mudanças naturais ou por atuação do homem). 
Possui uma dinâmica caracterizada por mudanças reversíveis, periódicas e que conduzem à uma mudança de sua estrutura. A paisagem portanto insere-se no quadro natural geral que é abarcado pelo Geossistema. O conceito de Geossistema foi definido pelo geógrafo soviético Sotchava em 1963, e foi utilizado em inglês em 1967 pelo geógrafo Sttodart e em alemão em 1969 por Neef Id Ibidem (ABREU,1983). A partir de então o termo vem sendo tratado como terminologia científica e sendo utilizado por todos os especialistas da Ciência da Paisagem, correspondendo à aplicação do conceito de sistema e à concepção sistêmica de paisagem, Bolós (1992; pg. 36).

Por outro lado, a concepção de Bertrand (1971) apresenta o elemento antrópico mais vinculado aos geossistemas do que a definição de Sotchava. Bertrand redefiniu o geofácie como um setor fisionomicamente homogêneo, onde se desenvolve uma mesma fase da evolução geral do geossistema com aproximadamente centenas de $\mathrm{m}^{2}$. O geótopo constitui os setores internos do geofácies, sendo a menor unidade geográfica homogênea que possui maior interrelação dos elementos componentes.

A abordagem do geossistema é um meio para o diagnóstico de um dado espaço, (...) é a base da qual se possa atingir uma avaliação econômica (...) e, assim uma projeção mais adequada a uma razoável prognose (MONTEIRO, 2000).

Por fim, a teorização de Tricart (1977) sobre a Ecodinâmica da Paisagem completa nosso embasamento teórico. A Ecodinâmica no entanto é baseada no estudo da dinâmica dos ecótopos 4 .

4 Ecótopos: A parte dinâmica dos ecossistemas o qual Jean Tricart (1977) o denomina de Ecodinâmica. Segundo o autor essa dinâmica é tão importante para a conservação e o desenvolvimento dos recursos ecológicos quanto a dinâmica das próprias biocenoses (Tricart, 1977 p.31). 
A dinâmica do meio ambiente dos ecossistemas é tão importante para a conservação e o desenvolvimento dos recursos ecológicos quanto a dinâmica das próprias biocenoses (TRICART, 1977).

Segundo o autor, uma unidade ecodinâmica se caracteriza pelo realce dos processos do meio ambiente que tem repercussões mais ou menos imperativas sobre as biocenoses, dando-Ihes novas características.

\subsubsection{O modelo geossistêmico e os problemas} ambientais urbanos

$\mathrm{Na}$ Geografia Física a introdução de estudos referentes ao Geossistema é relativamente novo. Esta linha de pesquisa tem como objetivo pesquisar e colher dados ambientais para se fazer correlações, para, por fim, entender a natureza de todos os componentes. O enfoque Geossistêmico tem como base a "Teoria Geral dos Sistemas".

Embora tenha sido aplicada primeiramente nas ciências exatas (Sistemas), o conceito de Geossistemas surgiu na década de 1960 na antiga União Soviética, sendo primeiramente proposto pelo Russo Sotchava (1963) e logo após por Bertrand (1968).

\footnotetext{
Um geossistema é o potencial ecológico de determinado espaço no qual há uma exploração biológica, podendo influir fatores sociais e econômicos na estrutura e expressão espacial (SOTCHAVA, 1968).
}

O estudo dos sistemas, que já era bastante aplicado às ciências exatas, foi primordialmente introduzido à Geografia por Chorley (1962). O princípio básico do estudo de sistemas é o da conectividade.

Pode-se compreender um sistema como um conjunto de elementos com um conjunto de ligações entre esses elementos; e 
um conjunto de ligações entre o sistema e seu ambiente, isto é, cada sistema se compõe de subsistemas, e todos são parte de um sistema maior, onde cada um deles é autônomo e ao mesmo tempo aberto e integrado ao meio, ou seja, existe uma interrelação direta com o meio.

Quando não ocorrem as ligações sistema/ambiente ele é denominado sistema fechado; muito raros de se encontrar na natureza. É mais comum depararmos com o que seria um conjunto de aglomerados, interligados por redes de comunicações, formando um sistema espacial, no qual as ligações com outros sistemas ou aglomerações situadas fora de sua área constituem os contatos ou as interações com o ambiente. Ao analisarmos um dado espaço, se nós avaliamos apenas os seus elementos, sua natureza, sua estrutura ou as possíveis classes desses elementos, não ultrapassamos os limites da descrição.

Existe uma diferença primordial entre Geossistema e Ecossistema, fato este que exclui qualquer confusão, pois o Ecossistema:

É a unidade que inclui a totalidade de organismos em uma área interagindo com o meio ambiente físico, de modo que o fluxo de energia promove a permuta de materiais entre os componentes vivos a abióticos (CHRISTOFOLETTI, 1995).

Por outro lado, a natureza do estudo de Geossistemas segundo Sotchava, reside no fato de que:

Em condições normais deve-se estudar, não os componentes da natureza, mas as conexões entre eles; não se deve restringir à morfologia da paisagem e suas divisões mas, de preferência, projetar-se para o estudo de sua dinâmica, estrutura funcional, conexões, etc. (SOTCHAVA, 1968). 
O autor destaca ainda o dinamismo do geossistema que além de abertos podem ser hierarquizados dentro de sua organização que pode ser desde uma área elementar da superfície até o planeta, passando por subdivisões ou categorias intermediárias, lembrando no entanto que as unidades espaciais do geossistema acham-se na dependência de sua organização geográfica, sendo assim suas subdivisões não são ilimitadas. Sotchava destaca o tempo e o espaço como fatores a serem considerados em um geossistema, sendo que esse tempo deve ser avaliado por meio de eras, a "mobilidade no interior do estágio de uma era é a essência de sua dinâmica e a transição de em estágio temporal para outro, significa sua evolução", (SOTCHAVA, 1962).

Tendo como foco principal o funcionamento e a necessidade de se entender os geossistemas, Sotchava deixa claro a necessidade de também se caracterizar a adição de valores sociais e econômicos dentro de um geossistema, afirmando que:

Os geossistemas são fenômenos naturais, todavia os fatores econômicos e sociais, ao influenciarem sua estrutura e peculiaridades espaciais, devem ser tomados em consideração (SOTCHAVA, 1962).

Por isso mesmo, a ocupação do sítio urbano e a urbanização está intrinsecamente relacionada com as impressões oriundas da atividade econômica realizada sobre tal sítio, promovendo interconexões que dinamizam os sistemas físicos e sociais.

O estudo de geossistemas é uma das formas de interpretação dos fenômenos espaciais que devido aos processos e atividades de uso do assoalho urbano, torna-se aplicável do ponto de vista conceitual.

A Geografia Física que antes era uma ciência pautada a compartimentar as várias disciplinas acadêmicas que tinham por 
objetivo fragmentar através da análise todos os componentes naturais, evoluiu para uma prática de correlacionar as nuanças existentes entre os meios físicos e suas trocas de energia, dando campo à introdução do conceito de Geossistemas, enquanto conceito teórico mais amplo.

Tomando-se como ponto de partida de que os geossistemas são sistemas territoriais sociais e naturais (SOTCHAVA), surge a importância da discussão e compreensão do termo. Há contudo, uma evolução também conceitual do estudo das paisagens e também dos geossistemas, ficando claro que o primeiro deu a base para o segundo no que se refere às suas características teóricas e até metodológicas.

Bien souvent, l'aspect relationnel et dynamique des géosystèmes s'avère désormais davantage digne d'interêt que l'examen des faits de structuration spatial (BEROUTCHACHVILI et all, 1977).

Os geossistemas apresentam um aspecto dinâmico e relacional. A teoria de geossistemas surgiu, na escola russa, de um esforço de teorização sobre o meio natural com suas estruturas e seus mecanismos tal como existem objetivamente na natureza. A base dessa teoria corresponde ao conceito de que as geosferas terrestres estão inter-relacionadas por fluxos de matéria e energia. É um artifício teórico para interpretar a complexidade das relações sócio-ambientais.

O reflexo dessa interação na superfície terrestre é a existência de uma geosfera complexa (Esfera fisico-geográfica) que comporta a forma geográfica do movimento da matéria. Ribeiro (2000). O geossistema contudo é a parte teórica da tentativa de interpretação da Paisagem de uma forma mais científica e relacional (Homem x Natureza). 
E é através dos fluxos de energia e da intensa atividade antrópica, pois o geossistema nada mais é que um sistema complexo de fácies que forma o interior da paisagem com associações territoriais e adicionadas de séries dinâmicas e fatoriais de diferentes gêneros Sotchava apud (SOTCHAVA apud BEROUTCHACHVILI et all 1977).

Desde à CSIRO (Commonwealth Scientific and Industrial Research Organization), passando pelo conceito de LANDSCAPE ECOLOGY, como também pelo conceito de GEOSSISTEMAS utilizado no leste europeu, os pesquisadores sempre interessaram-se particularmente pelo componente material da paisagem, considerando ai o relevo como a base de sua organização, visto que, no sistema urbano o sítio (assoalho) é de crucial importância tanto na e para a ocupação quanto para o crescimento horizontal da cidade.

\subsubsection{O conceito e a importância do sítio urbano}

$\mathrm{Na}$ ciência geográfica, além da dicotomia existente entre Geografia Física e Geografia Humana, alguns termos são bastante utilizados, que se referem tanto aos estudos de caráter social quanto físico, o uso de tais termos acaba criando modismos.

O termo "sítio urbano" 5 pode ser tomado como exemplo, pois é um conceito analítico que antes em voga na Geografia, hoje dá espaço a outros conceitos, o mesmo não perdeu sua importância enquanto categoria de análise, este termo antes utilizado com freqüência foi gradualmente substituído por outros como "uso do solo" ou "uso da terra".

Enquanto o sítio remete à forma e sua base material, o uso da terra remete à forma de apropriação. Resume-se a partir desse

${ }^{5}$ Categoria de análise na Geografia que diz respeito às feições de um modelado de uma cidade, substrato que abriga a estrutura urbana caracterizada pela presença de elementos topográficos (Ab'Saber,1952). 
problema a dialética: propriedades geoecológicas versus propriedades sócio-reprodutoras. As propriedades sócioreprodutoras são muitas vezes incompatíveis com as propriedades naturais ou geoecológicas o que em momentos críticos geram rupturas ou o colapso do território urbano ou até mesmo rural.

O sítio urbano se destaca por ser o campo onde as relações sociais se concretizam modificando as características físicas préexistentes, o mesmo termo aparece nas bibliografias principalmente como tendo uma natureza geomorfológica intrínseca à mesma. O tratamento dado à análise do relevo das cidades muitas vezes desemboca na caracterização do sítio urbano, pois quase sempre relevo e sítio são confundidos, já que - relevo está ligado geralmente à estrutura que lhe formou (aspectos geológicos), enquanto o sítio urbano está mais ligado à parte superficial do modelado.

O sítio urbano é caracterizado na contemporaneidade, principalmente, pelo estabelecimento das grandes metrópoles como sendo o resultado da ação antrópica intensiva e da busca incessante de novas tecnologias que tornem a vida humana mais prática. Como afirma Harvey (2005), “...o ritmo e a escala assustadores do processo de urbanização nos últimos cem anos significam, por exemplo, que fomos refeitos muitas vezes sem saber por quê, como ou para quê...".

A partir de nossas hipóteses de estudo temos o questionamento central, de que a evolução urbana, principalmente na RMSP, provocou e ainda provoca impactos ambientais que modificam as propriedades geoecológicas e desestruturam as condições naturais pré-estabelecidas, em que Taboão da Serra é apenas um exemplo do contexto geral, sendo especial no que se refere à sua diminuta área e do seu adensamento populacional e de construções que modifica a forma de ocupação do sítio urbano. 
Desta forma, o termo sítio urbano é primordial pois, ele permite a comparação com o uso e a avaliação de suas conseqüencias. Um sítio tem uma característica geoecológica que para melhor uso deve ser considerada no planejamento urbanopaisagístico.

Os problemas ambientais principalmente aqueles ligados aos centros urbanos estão em pauta na atualidade. Por sua vez a geomorfologia, como parte integrante da análise geográfica e responsável pela compreensão do comportamento do relevo, fundamentando-se no conceito de "fisiologia da paisagem", procura evidenciar, de uma forma dinâmica, as derivações ambientais resultantes do processo de apropriação e ocupação do relevo ou de suas interfaces (como a cobertura vegetal) pelo homem. (CASSETI, 1995).

A questão ambiental é um temário atual que se mostra importante pela implicação danosa da ação antrópica, principalmente aquelas que ocorrem nas cidades. Esta é uma preocupação do final do século $X X$ e que é ainda mais urgente no início do século XXI, esta questão tem como argumento principal a compreensão dialética das relações sociedade e natureza colocando de lado o dualismo.

O processo de formação dos solos e aqueles das regiões tropicais, tem características próprias que as distinguem de qualquer outra região do planeta. As alterações das características físicas, químicas e biológicas, tem correlação intrínseca com as características do domínio climático no qual a região se localiza, no caso da faixa intertropical, as temperaturas médias anuais sempre elevadas acentuam o processo de formação dos solos através da ação decisiva das temperaturas e das chuvas.

Nei tropici tanto i fattori di ambiente come le correlazioni fra questi hanno aspetti particolari. Il clima esterno tipico crea un clima interno, o di terreno, pure tipico, 
cosí da determinare alterazioni di ordine fisico,chimico e biologico caratteristiche (GIGLIOLI, 1978).

Portanto as alterações das características dos solos e conseqüentemente do relevo são influenciados principalmente pelos domínios climáticos zonais. Da mesma forma, a intensidade da pluviosidade, sua duração, juntamente com as características do solo urbano irão responder pelos processos morfogenéticos atuantes, ou pela falta deles.

\subsubsection{Características da energia no geossistema}

A energia no geossistema é um componente atuante que define as leis de fluxos dentro do ambiente. Num sistema urbano estas leis são organizadas por um componente natural e outro antrópico sendo que, o segundo redefine as leis energéticas provocando por vezes desequilíbrio.

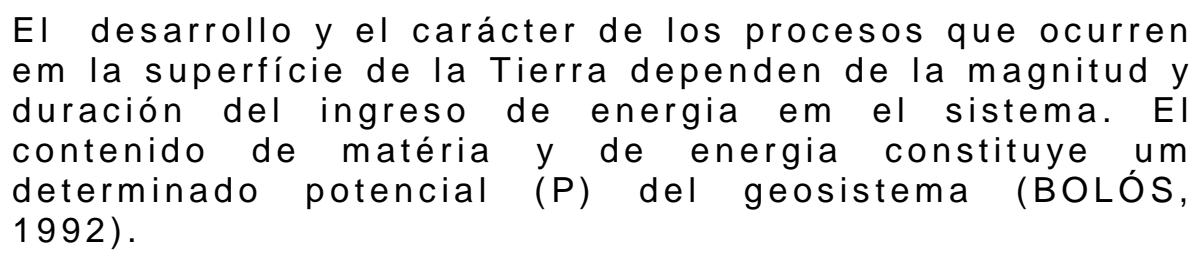

Existe uma estrutura vertical e outra horizontal dentro de um mesmo geossistema, que no caso são as interdependências relativas de determinadas características em relação ao seu funcionamento. A repartição das massas nos geossistemas é considerada como sendo o limite superior do geossistema e o limite inferior aquele no qual não se experimenta nenhuma variação térmica provinda da energia exterior. (BOLÓS, 1992).

Sobre o comportamento do geossistema, considera-se que o mesmo apresenta mudanças de estado no tempo e que não é ordenado sem que obedeça somente a determinadas regras em relação aos processos externos e internos ao mesmo. 0 
"comportamento" do geossistema é a sucessão dos diferentes estados, o qual define neste aspecto o próprio geossistema.

\subsubsection{Desenvolvimento da Geomorfologia}

A dinâmica urbana atual, impõe uma funcionalidade ao espaço urbano que freqüentemente exerce um papel nocivo ao assoalho da cidade, ante à ocupação desordenada. Os resultados negativos desta "funcionalidade" mostram-se que cada vez estão mais ligados aos fatores econômicos do que à própria forma de ocupação do solo urbano.

As forças produtivas, por sua vez, que tratam das relações do homem com a natureza, correspondem a determinadas relações de produção, evidenciadas nas diferentes fases da história da humanidade. (CASSETI, 1995).

Os elementos internos das forças produtivas são justificados por duas categorias básicas: a força de trabalho e os instrumentos de trabalho, que por sua vez se relacionam intrinsecamente com o desenvolvimento científico-tecnológico dando origem a uma configuração espacial.

Do ponto de vista da evolução dos estudos em Geomorfologia, alguns estiveram ligados no passado à geopolítica, como forma de atender aos anseios expansionistas de países europeus e também corroborar para o domínio do saber científico sobre outras nações.

O expansionismo colonialista dos países europeus no continente africano, fez com que a Alemanha ficasse à parte do processo, a política cultural nacionalista adotada pela Alemanha, sob a influência prussiana, apesar de não ter impedido um relativo desenvolvimento interno, deixou-a de fora da partilha dos territórios coloniais Casseti (1995). O pensamento alemão 
implicou num latente desenvolvimento interno de vários ramos científicos e dentre eles a geomorfologia.

A filogênese ${ }^{6}$, epistemologia ${ }^{7}$ e a sistematização da geomorfologia no século XVIII foi resultado do desenvolvimento econômico alemão e da atenção dada às ciências. No final do século XIX e no decorrer do século XX, surgiram duas tendências distintas da filogênese da teoria Geomorfológica que se destacam por tentar aprofundar um campo de estudo que outrora estava confusa e que apesar dos esforços, existem ainda pontos de intensa discussão acerca da epistemologia da ciência, (Abreu, 1983), distingue assim dois ramos principais da filogênese geomorfológica: A tendência Anglo-americana e tendência Germânica (ABREU, 1983).

\subsection{Embasamento Conceitual Instrumental}

As atividades humanas (sociais e econômicas) sobre a superfície terrestre, tornam-se incessantemente mais complexas, advindo daí a necessidade de estudos que impliquem em coleta, análise e proposição de prognósticos que nos levam a delimitar a realidade através da Tecnologia da Informação e especialmente através dos SIG's (Sistemas de Informações Geográficas). Os modelos são padrões empíricos que são necessários na análise das estruturas do mundo real.

$\mathrm{Na}$ elaboração de um modelo, a definição das necessidades de informação, ou seja, aquelas que são relevantes para o propósito da aplicação, corresponde ao estabelecimento de quais aspectos do mundo real interessa e é possível observar (RODRIGUES, p.90).

6 Filogênese: Evolução pela qual as formas vivas inferiores se vão modificando para produzirem outras, cada vez mais elevadas, sucessão genética das espécies orgânicas.

Epistemologia: teoria do conhecimento conhecimento científico em seus vários ramos. 
No nosso exemplo, traremos para o contexto da problemática ambiental, as estruturas superficiais criadas, levando em conta as pressões que as mesmas causam sobre o solo urbano e sobre o escoamento pluvial da área em estudo.Na elaboração de um Sistema de Informações Espaciais, surge a necessidade do apoio de um Banco de Dados Geográfico, o qual nada mais é que uma coleção de dados num sistema hierarquizado.

Geoprocessamento "a técnica" nada mais é que um conjunto de operações relacionadas e que utiliza um Banco de Dados como suporte.

ou ainda...

O geoprocessamento é um conjunto poderoso de ferramentas para coletar, armazenar, recuperar, transformar e visualizar dados sobre o mundo real (BURROUGH, 1986).

Um banco de dados indexados espacialmente, sobre o qual opera um conjunto de procedimentos para responder a consultas sobre entidades espaciais (SMITH et all 1987 apud SPRING, 2000).

Dando uma interpretação mais ampla alguns autores afirmam que o geoprocessamento é:

Um conjunto manual ou computacional de procedimentos utilizados para armazenar e manipular dados georreferenciados (ARONOFF, 1989).

No contexto nacional a aplicação da ferramenta dos SIG's e do Geoprocessamento desenvolve-se com o apoio de centros de pesquisas oficiais, principalmente aquelas pesquisas desenvolvidas pelo INPE (Instituto Nacional de Pesquisas Espaciais) através do DPI (Departamento de Processamento de Imagens) que recebeu impulso com as pesquisas multilaterais realizadas com o programa de cooperação internacional por parte do Brasil e da China, que colocou em órbita 2 satélites de pesquisas ambientais (CBERS 1 e CBERS 2 - China and Brazil Environmental Research Satelitte) que dá apoio à aquisição, 
armazenamento, e desenvolvimento do Geoprocessamento nacional atualmente.

Desta forma a tecnologia da informação apóia-se no geoprocessamento que é a ferramenta rápida e confiável na elaboração de diagnósticos ambientais.

O geoprocessamento pode ser definido como o uso automatizado de informação, que de alguma forma está vinculado a um determinado lugar no espaço, seja por meio de um simples endereço ou por coordenadas (CÂMARA, 1998).

Os SIG's e o Geoprocessamento distinguem-se principalmente, pelo primeiro ter como característica principal a análise espacial. O Sistema de Informações Geográficas distingue-se de outros sistemas no que se refere a poderosa ferramenta de análise espacial, ou seja, cruzamento de informações geográficas (espacial) e Banco de Dados que permitem respostas às questões que envolvem o Espaço Geográfico, onde insere-se o uso do solo urbano.

\subsubsection{Banco de Dados e os Sistemas de Informações Geográficas: Especificidades}

Os sistemas de informações na atualidade tornam-se ferramenta cada vez mais usuais, que facilitam a entrada, manipulação e atualização de dados, principalmente aqueles dotados de georeferenciamento espacial. Os SIG's (Sistemas de Informações Geográficas) são as ferramentas computacionais do geoprocessamento que é uma técnica de análise e interpretação das características espaciais e que estão associadas a entes delimitados por coordenadas $(x, y, z)$.

Eles realizam análises complexas, ao integrar dados alfanuméricos com dados geográficos de uma determinada área de estudo, através de um banco de dados georeferenciados. 
Os SIG's têm a capacidade de manipular dados espaciais (cartográficos, cadastrais, sensoriamento remoto,modelos numéricos de terreno) e dados não-espaciais (descritivos ou alfanuméricos), de forma integrada, provendo uma base consistente para análise e consulta. Logo, é possível ter acesso às informações descritivas de uma entidade geográfica a partir de sua localização geográfica e vice-versa Filho (1997).

O Geoprocessamento pode ser definido como uma ferramenta para o planejamento e controle ambiental como também um instrumento de suporte à decisão:

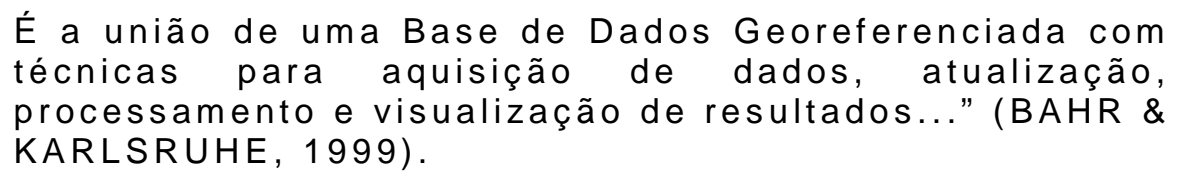
técnicas para aquisição de dados, atualização, processamento e visualização de resultados..." (BAHR \& KARLSRUHE, 1999).

O processo de modelagem é uma característica inerente ao design de sistemas gráficos de imagens e quatro universos (níveis de abstração) envolvidos podem ser distinguidos. Gomes e Velho (1995) apud (SPRING, 2000):

- O primeiro nível chamado de universo do mundo real, inclui as entidades da realidade que são modeladas no sistema. E também o universo matemático (conceitual) que inclui uma definição matemática (formal) das entidades que serão incluídas no modelo;

- Segundo, o universo conceitual, onde as estruturas do mundo real são transformadas em entidades abstratas como os campos e os objetos de representação;

- Terceiro, o universo de representação, onde as diversas entidades formais são mapeadas para as representações gráficas utilizadas no modelo;

- Quarto, o universo de implementação, onde as estruturas de dados e algoritmos paras as operações 
nos dados geográficos são escolhidos, baseados em considerações como desempenho, capacidade do equipamento e tamanho da massa de dados. É neste nível que acontece a codificação.

Nota-se que a visão da modelagem apresentada, não se limita a sistemas de geoprocessamento. Sua aplicação ao problema de geoprocessamento é particularmente apropriada, pois permite equacionar os problemas da área, pois a partir do universo do mundo real, encontramos os tipos de dados a serem representados (mapas de solos, cadastro urbano e rural, dados geofísicos e topográficos).

No universo conceitual, onde pode-se distinguir entre as grandes classes formais de dados geográficos (campos e objetos), espacializando estas classes nos tipos de dados geográficos utilizados comumente (mapas temáticos e cadastrais, modelos numéricos de terreno -MNT-imagens de satélites).

Já no universo de representação, as entidades formais são associadas a representações geométricas, que podem variar conforme a escala e a projeção cartográfica escolhida. Podem se distinguir entre as representações matricial "raster" e "vetorial" que podem ainda ser espacializadas. Finalmente, no universo de implementação as estruturas de dados são escolhidas e o sistema é codificado.

Com base nesta visão, as dicotomias tradicionais do geoprocessamento (campos-objetos e matricial-vetorial) podem ser resolvidas, mostrando que elas encontram-se em níveis distintos de abstração. Esta análise também indica que a interface de usuário de um SIG deveria refletir, tanto quanto possível, o universo conceitual e omitir detalhes dos universos de representação e implementação. No nível conceitual, o usuário lida com conceitos mais próximos da realidade e minimiza a 
complexidade envolvida dos diferentes tipos de representação gráfica Araujo (2003).

\subsubsection{Uso da terra e o sensoriamento remoto}

A crescente necessidade de se observar as transformações ocorridas na Terra, forçaram os países a desenvolver tecnologias que pudessem ser aplicadas no mapeamento da superfície a partir de plataformas espaciais, estas plataformas são os conhecidos satélites de monitoramento ambiental e também àqueles construídos para uso militar. O advento da utilização de imagens a partir de plataformas orbitais, que tem início na década de 70 , colaborou para a proliferação dos estudos de mapeamento do uso e ocupação do solo, sejam elas em quaisquer parte do planeta, apesar de que, o acesso às imagens com melhores resoluções espaciais e espectrais ainda sejam privilégio dos países desenvolvidos ${ }^{8}$. O sensoriamento remoto ${ }^{9}$ é uma técnica que tem como objetivo captar à distância dados na superfície terrestre, ou seja a captação de objetos ou fenômenos, ou mais comumente, o sensoriamento remoto é a utilização de sensores para aquisição de informações sobre objetos ou fenômenos sem que haja contato direto entre eles. Spring, INPE (2008).

\footnotetext{
${ }^{8}$ Como exemplo temos as imagens geradas a partir do satélite Ikonos, que apresenta uma maior resolução espacial $60 \times 60 \mathrm{~m}$.

${ }^{9}$ A origem do sensoriamento remoto está ligada as experiências de Newton (1822), o qual constatou que um raio luminoso (luz branca), ao atravessar um prisma, o mesmo desdobrava-se num feixe colorido - um espectro de cores. Desde então os cientistas foram ampliando os seus estudos a respeito de tão fascinante matéria. Verificaram que a luz branca era uma síntese de diferentes tipos de luz, uma espécie de vibração composta, basicamente, de muitas vibrações diferentes. Prosseguindo, descobriram ainda que cada cor decomposta no espectro correspondia a uma temperatura diferente, e que a luz vermelha incidindo sobre um corpo, aquecia-o mais do que a violeta. Spring (INPE, 2008).
} 
O mapeamento de uso e ocupação, sejam eles urbanos ou rurais, tornou-se de fundamental importância para a compreensão dos padrões de organização desses espaços, assim como de sua evolução temporal, que mostram-se cada vez mais alterado pela ação antrópica e pelo desenvolvimento tecnológico.

Dessa forma, é evidente que existe a necessidade de atualização constante dos registros de uso e ocupação do uso da terra, para que suas tendências possam ser analisadas, com o objetivo de fornecer subsídios às ações do planejamento regional Rosa (1990). A partir dessa perspectiva, o conhecimento atualizado das formas de utilização e ocupação da terra, como também seu uso histórico, tem sido um fator imprescindível ao estudo dos processos que se desenvolvem na região, tornando-se de fundamental importância, na medida em que os efeitos do seu mau uso, causam deterioração no meio ambiente, tais como: processos intensos de erosão, desertificação, inundações, assoreamento de cursos d'água tem sido exemplos cotidianos de mau uso.

A captação da energia eletromagnética (Fig. 08) proveniente dos objetos é realizada através dos sensores acoplados às plataformas espaciais e estes sensores são equipamentos capazes de coletar energia oriunda do objeto, convertê-la em sinal passível de ser registrado e apresentá-lo em forma adequada à extração de informações. 


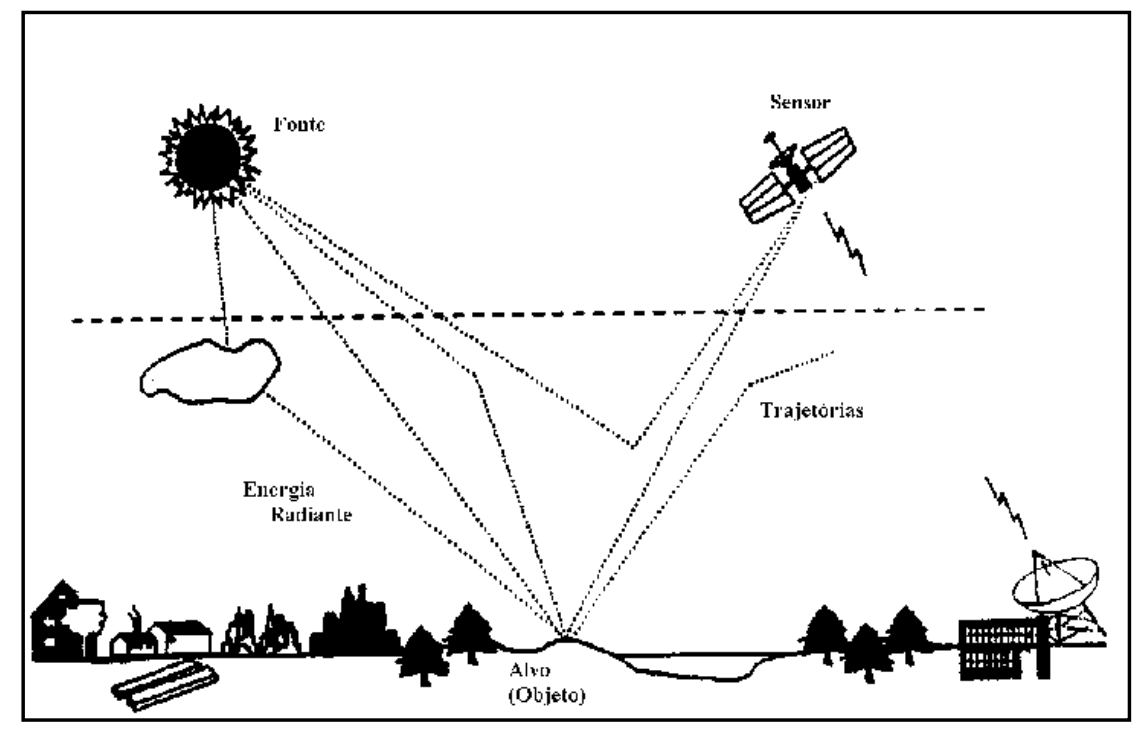

Fig.08 - Captação de dados em sensoriamento remoto: trajetórias da radiação eletromagnética. Adaptado de Spring/INPE.(2008).

O alto custo para desenvolver um satélite de monitoramento ambiental, faz com que os países em desenvolvimento, tornem-se dependentes do Banco de Dados de Imagens cedidas pelos países que detêm essa tecnologia, no caso do Brasil, parcerias com a China tentam driblar essa dependência com o desenvolvimento das plataformas orbitais caracterizadas pela série CBERS I e II.

Ribeiro da Silva (2004) diz que a cidade é um espaço dinâmico, resultante da atuação constante dos agentes produtores do espaço urbano, sendo local que possibilita a maximização da reprodução capitalista. Ao mesmo tempo, é resultado do conjunto de práticas sociais, de fatores econômicos e políticos que se expressam no interior da sociedade.

De acordo com Bouchard et all (1997), a atividade humana constitui a maior força no processo de transformação da paisagem, embora, existam situações onde o uso da terra seja cerceado pelas características físicas existentes. 
As mudanças dos padrões espaciais no sistema intra-urbano são perceptíveis através da análise minuciosa de imagens com alta resolução embora,a compreensão dos padrões dessas mudanças, de suas características e conseqüencias socioambientais, deverá conduzir ao aprimoramento da capacidade de predizer dinâmicas futuras e estabelecer diretrizes e ações para o gerenciamento local (KIENAST, 1993).

A expansão das áreas urbanas é uma tendência que marca tanto o efeito da horizontalização quanto o da verticalização do crescimento das cidades, neste caso, atualmente, o intenso processo de expansão das áreas urbanas e o crescimento populacional tendem a competir com as condições ambientais, tais como reservas florestais, parques, áreas de proteção e conservação (O'HARA et. all. 2003).

O uso sistemático de imagens orbitais de Sensoriamento Remoto, sobre as quais são delimitadas as células elementares UTBS (Unidades Territoriais Básicas), são células caracterizadas quanto aos componentes da paisagem, dentre elas a geologia, geomorfologia, pedologia e vegetação, tem sua vulnerabilidade à erosão avaliada segundo a relação entre os processos de pedogênese e morfogênese que são processos intrínsecos à paisagem, (CREPANI et all. 1996).

Tais processos podem ser cartografados a partir da base orbital e dos sistemas sensores, que apoiados em Banco de Dados Geográficos são cruzados e comparados buscando interpretar as transformações superficiais em áreas antropizadas e nãoantropizadas.

Essas transformações espaciais se processam ao longo do tempo e segundo Dramstad et all (1996), é necessário entender como funcionam e se processam as variações dos padrões de mudanças da paisagem pois, cada paisagem tem sua assinatura e entender a composição desse mosaico é o maior desafio. Dentro 
dessa perspectiva, a caracterização das paisagens urbanas tornam-se especialmente importante pois, as técnicas de Sensoriamento Remoto desempenham um importante papel no estudo da variação das paisagens (SMALL ,2001).

O interesse contínuo na aplicação das geotecnologias, dentre elas o sensoriamento remoto e os SIG's no estudo do meio ambiente e, na interpretação dos tipos de uso da terra tem como pano de fundo o planejamento territorial. Segundo Valente \& Castro (1983), uma das dificuldades para o planejamento é a conciliação entre os programas conservacionistas e a exploração econômica.

Sendo assim, a análise das características, como cobertura vegetal, topografia, drenagem e tipo de solo, permite chegar ao uso racional e adequado de um determinado espaço geográfico. Dessa maneira, determinam-se áreas de preservação de mananciais, reservas florestais, áreas agrícolas, distritos industriais e áreas de expansão urbana, para que o uso do solo obedeça às características naturais da bacia ou do solo urbano, e o planejamento considere o desenvolvimento sustentado (TUCCI, $1993)$.

Um Banco de Dados é um suporte essencial para se proceder a análise têmporo-espacial da expansão urbana, desse modo, existe a necessidade de atualização sem cessar dos dados de uso e ocupação do solo, para que suas tendências possam ser diagnosticadas e analisadas, com o objetivo de fornecer subsídios às ações do planejamento regional (ROSA, 1990). 


\subsubsection{Da contribuição da fotogrametria}

A fotogrametria, é um dos métodos mais utilizados para a confecção de produtos cartográficos que tem como objetivo, a produção dos modelos digitais de elevação ${ }^{10}$.

Faz parte do grupo pertencente a um nível aéreo de coleta de dados, os quais incluem-se todos os sistemas sensores, sejam eles convencionais ou não-convencionais, que tem como base de operação as aeronaves.

A detecção das rugosidades da superfície é o objetivo primordial na fotogrametria. E o modelo numérico é um dos resultados da produção de ortofotos.

Segundo Azevedo (1994), o Brasil é um país que possui relativa cobertura de vôos aerofotogramétricos, sabendo-se que em umas regiões mais do que em outras, há uma maior cobertura aerofotogramétrica em variadas escalas realizadas pelas empresas nacionais de aerofotogrametria, bem como através do vôo americano realizado pela USAF (United States Air Force).

Pode-se afirmar que o banco de dados referente aos tipos de fotografias aéreas abrangendo partes do território nacional, principalmente no centro-sul na escala 1: 10.000, às quais são utilizadas para a confecção de cartas temáticas planialtimétricas, são comuns na maioria das empresas particulares e públicas.

Do ponto de vista da geografia, a interpretação visual das feições da superfície tem como objetivo diagnosticar como no caso de estudo o avanço da urbanização, tanto em nível vertical quanto horizontal.

${ }^{10}$ Este termo é também referenciado na bibliografia geral como Modelos Numéricos de Terreno (MNT) ou Modelos Digitais do Terreno (MDT), do inglês (DEM) Digital Elevation Model. 
A verticalização é o processo de adensamento de determinadas áreas urbanas, através da construção de edifícios, ocorrendo, geralmente nas regiões centrais das cidades. Em Taboão da Serra, este processo torna-se mais evidente pela diminuta área do município e pela aceleração do processo de verticalização, tanto no centro quanto na periferia, neste último o fato torna-se mais problemático por apresentar construções de baixo padrão, criando uma urbanização concentrada.

Alguns autores não-geógrafos, emitem uma opinião que se aproxima do contexto da geografia quando se fala em adensamento populacional e verticalização. Para Somekh (1994), a verticalização é definida como a multiplicação efetiva do solo urbano, possibilitada pelo uso do elevador. A partir dessa conceituação, associam-se características da verticalidade, o aproveitamento intensivo da terra urbana (densidade) e o padrão de desenvolvimento tecnológico do século $X X$, que resulta na demonstração de uma relação próxima entre verticalização/adensamento.

Dentro do contexto da interpretação da verticalização e do adensamento, as fotografias aéreas são fontes importantes para tal pois, são objetos de informações sobre o espaço urbano e podem fornecer subsídios à análise destes processos. A sua interpretação permite a visualização e identificação dos diferentes elementos que constituem um espaço urbano.

De acordo com Foster (1985), uma área urbana é composta por variados alvos, tais como: concreto, asfalto (ruas, avenidas), telhados de diversos materiais, solo exposto, grama, árvores, água etc. A maioria destas coberturas são menores que a resolução de um pixel (elemento de resolução). Desta forma, nem todos os sensores orbitais são adequados ao estudo de áreas urbanas, sobretudo aquelas densamente povoadas, pois nem todos conseguem amenizar estes problemas. 
Mesmo com toda essa dificuldade de visualização dos objetos menores, ainda assim com toda essa complexidade do ambiente urbano, sensores com maior resolução espacial tais como (TM, HRV/PAN-SPOT, respectivamente Thematic Mapper, Haut Resolution Visible,Pancromático-Système Pour l'Observation de La Terre) integram menor variedade de informação que o MSS (Multispectral Scanner)representando o ambiente urbano com maior fidelidade e facilitando a visualização de um maior número de detalhes, mesmo assim, a identificação de aspectos relacionados às condições físicas do intra-urbano não são facilmente visualizadas e viabilizadas. 
5. PROCEDIMENTO METODOLÓGICO

ABORDAGEM TEÓRICA E PESQUISA APLICADA 


\subsection{Abordagem Teórica: Vulnerabilidade e Risco} Ambiental

A ocupação desordenada de áreas íngremes na cidade de Taboão da Serra, notadamente nos trechos com maiores declives, tem provocado problemas de risco ou de instabilidade de fato das encostas. A medida que o processo de ocupação desordenada se acelera como conseqüencia do grave quadro social que sofre a população de baixa renda, os problemas se acentuam pois passam a ser ocupadas regiões extremamente desfavoráveis para a construção de moradias.

Alia-se a esta ocupação desordenada, a falta de infraestrutura, o que ocasiona problemas de escorregamentos e inundações, bem como o acúmulo de lixo na região. Juntamente com a ocupação e a proliferação de tipos de construções, percebe-se a exposição da população ao risco ambiental, somatizando o risco com o fator vulnerabilidade como exemplificase nas situações de ocupação de encostas nas áreas periféricas da cidade (Foto08).

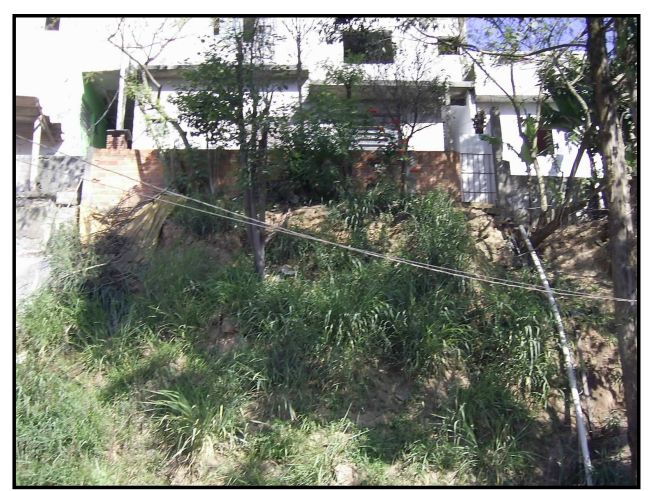

Foto 08: Zona de ocupação de encostas e retirada da proteção vegetal natural. 
Segundo Godard (1988) e Nyèrges (1997), um local pode ser vulnerável mas pode não apresentar riscos, ainda sobre risco e vulnerabilidade,

Do ponto de vista fenomenológico, a associação de ambos os termos: vulnerabilidade e risco podem ser paradoxais, mas os riscos urbanos são construídos com a ocupação do meio natural, passando de um risco natural à um risco urbano. Isto implica por assim se dizer que, estamos vulnerável à qualquer evento natural embora não possamos afirmar que corremos certamente o risco de que um evento catastrófico realmente ocorra.

$\mathrm{Na}$ visão de D’Ércole (1995), ainda sobre a natureza da vulnerabilidade, o autor esclarece que esta condição aparece muitas vezes como um sistema articulado por um grande número de variáveis naturais e antrópicas.

A configuração de um risco natural para um risco ambiental, pode ocorrer principalmente no meio urbano, e em especial nas cidades que tiveram um crescimento acelerado sem uma ordenação da ocupação do uso da terra.

As cidades e em especial as metrópoles dos países periféricos, tiveram um crescimento acelerado, onde o processo de "inchaço" (termo utilizado em referência ao crescimento descontrolado das mesmas, sem portanto estar acompanhado de bem-estar social), levou os grandes centros urbanos desses países como Brasil e México a apresentarem problemas graves de poluição ambiental e degradação do uso do solo.

Segundo a ONU (Organização das Nações Unidas-2002), duas das principais metrópoles mundiais em termos de população localizam-se na América Latina: Cidade do México e São Paulo e suas respectivas regiões metropolitanas apresentam graves problemas de degradação ambiental, orientados principalmente 
pelo intenso processo de antropização dos recursos naturais sem um devido cuidado.

Diante disso, as formas de urbanização adquirem um aspecto particular no contexto intra-urbano e os sistemas de urbanização de acordo com Lojkine (1981) apud (SANTO,1995), “...são antes de mais nada formas de divisão social e territorial do trabalho...". E é através da divisão social e posteriormente da divisão territorial que as cidades se exprimem pelo que são hoje em dia.

A influência do fenômeno do crescimento acelerado implica no crescimento desordenado, e este põe em risco toda a sociedade que está assentada numa base física por vezes não propensa à ocupação, tornando sua população mais vulnerável aos fenômenos climáticos e geomorfológicos.

La vulnérabilité apparaît dans certaines communications comme un système, articulé autour d'un grand nombre de variables, naturelles et humaines, don't la dynamique dans le temps et dans l'espace peut engendrer des situations plus ou moins dangereuses pour une société exposée (D’ÉRCOLE, 1995).

A vulnerabilidade ${ }^{11}$, não somente se explica pelas condições da base física a qual as populações estão assentadas, ela também pode ser diagnosticada pela condição do sítio ou pela forma do relevo e pelos sistemas ambientais atuantes, mas também pela característica da ocupação antrópica do local. Ainda sobre o conceito de vulnerabilidade, e de como ela se aplica nas áreas metropolitanas das cidades dos países desenvolvidos ${ }^{12}$, Andersen

11 Segundo a proposição de D’ÉRCOLE et al. (1995): “...A vulnerabilidade é um sistema composto de elementos e de fatores vulneráveis...". Está implícito o fator fragilidade, sejam elas nos níveis do meio natural ou antrópico. D’Ércole et al. P.323-324, 1995.

12 Segundo AB'SABER et alii (2002): “...é preciso reconhecer que as principais agressões sofridas pelo meio ambiente -em nível global- foram iniciadas e desenvolvidas pelos países industrializados.Não há de se esquecer, ainda, o fato de que processos de degradação ambiental acontecidos no interior da fronteira dos países do Norte foram depois sutilmente transferidos para os países subdesenvolvidos e a eles impostos de maneira sub-reptícia ou autocrática..." 
(1992) apud (SMYTH \& ROYLE 2000) define três características básicas para a instalação da vulnerabilidade que são:

- A concentração de pessoas e de atividades num espaço definido e limitado;

- Um grande número de pessoas em atividade;

- A probabilidade de ocorrência de eventos naturais pela ação antrópica;

Neste contexto, insere-se as variáveis que recebem e respondem aos inputs, sendo os principais fatores que sofrem modificações que são as características geoecológicas, ${ }^{13}$ ou aquelas que fazem parte do contexto natural do meio.

Já no sistema urbano existe um sentimento de pertencimento ao meio, que faz com que a população incorpore aos hábitos cotidianos uma relação próxima entre a fragilidade do ambiente que habitam e a necessidade de habitá-lo, por falta de alternativa econômica. Esse sentimento de pertencimento ao meio faz com que os riscos sejam apenas fatores ligados à natureza que são relegados ao esquecimento.

Embora os serviços oferecidos pelas cidades consigam dar conta das necessidades essenciais da população urbana, como em Taboão da Serra, a crescente densificação demográfica se reflete na quantidade de construções, que tem resultado negativo quando se avalia o impacto das mesmas sobre o assoalho urbano.

A complexidade das interações entre as atividades humanas e o ambiente cresce, portanto, na medida em que

13 As características geoecológicas, são aquelas que se ligam diretamente ao meio natural.São representadas na teoria Ecodinâmica de Tricart (1977) como participante dos Ecótopos que é a parte dinâmica dos ecossistemas, segundo o autor, essa dinâmica é tão importante para a conservação e o desenvolvimento dos recursos ecológicos quanto a dinâmica das próprias biocenoses, que é o local onde ocorre a vida havendo a interrelação de energia entre os seres vivos e o ambiente onde convivem. 
atualmente o processo de urbanização avança cada vez mais no mundo de hoje.

As transformações ocorridas na natureza e a atuação dos mecanismos que lhe são peculiares são capazes de, em circuitos contínuos de feedback positivos e negativos, gerar novas situações e processos cada vez mais complexos, forçando a novas adaptações ou ajustamentos da sociedade, e com elas, posteriores repercussões ambientais (GONÇALVES, 1992).

As transformações no entanto, acabam por provocar níveis extremos de estresse no ambiente, sobretudo no urbano. 0 condicionante psicológico com relação à vulnerabilidade ambiental torna-se cada vez menos perceptível, principalmente nos países onde o crescimento populacional ainda não se estabilizou.

Por outro lado, na maioria dos países desenvolvidos localizados no hemisfério Norte, há um crescimento populacional estabilizado, mas sua população como em todo o mundo estão também vulneráveis à ação de eventos, não se diferenciando neste ponto de vista dos países em desenvolvimento, estes últimos, localizados em sua maioria no hemisfério sul no que diz respeito à sensação de estarem sujeitos às intempéries naturais (vide exemplos atuais: vulcão na Islândia).

A diferença está no tratamento que o poder público aplica na prevenção e treinamento das populações dos países desenvolvidos ante à probabilidade de eventos naturais (como por exemplo, treinamento da população japonesa no caso da ocorrência de terremotos).

No contexto brasileiro, os trabalhos que discutem a vulnerabilidade e os riscos são realizados principalmente no departamento de Geografia da USP, sob orientação e de autoria do Prof. Jurandyr Ross, utilizando o relevo como fator de análise a partir dos seus índices de dissecação. 
Sobre a fragilidade ambiental segundo Ross (1994), as unidades de fragilidade dos ambientes naturais devem ser resultantes dos levantamentos básicos de geomorfologia, solos, cobertura vegetal/uso da terra e clima. Esses elementos tratados de forma integrada possibilitam obter um diagnóstico das diferentes categorias hierárquicas da fragilidade dos ambientes naturais.

A grande contribuição dos modelos de fragilidade ambiental é proporcionar uma maior agilidade no processo de tomada de decisões, servindo de subsídio para a gestão territorial de maneira planejada e sustentável, evitando problemas de ocupação desordenada, (SPORL, 2004).

Teses recentes abordam a mesma temática, Leme (2007), elabora trabalho com base na fragilidade de uma bacia hidrográfica em Piracicaba/SP. Sporl (2004), realizou pesquisa de doutoramento fazendo uma análise comparativa da fragilidade ambiental aplicando três modelos interpretativos. Amaral (2005), em sua dissertação estudou as unidades ecodinâmicas para diagnosticar a fragilidade ambiental do Parque Estadual do Morro do Diabo em Teodoro Sampaio/SP. Villela (2005), em pesquisa de mestrado elaborou trabalho sobre a fragilidade potencial do relevo num estudo geomorfológico da bacia hidrográfica do Ribeirão Mococa em Cristais Paulista /SP. Kawakubo (2005), sob orientação de Luchiari (2005) elaborou dissertação representando graficamente o relevo através de álgebra de mapas, no intuito de aplicá-los no estudo da fragilidade ambiental.

Dentro de um sistema existem condições dinâmicas que o torna vulnerável, tais características são implicações ou fatores que condicionam os elementos do meio. D'Ércole (1995) demonstra essa dinâmica num diagrama de fluxos (Fig. 09). 
76

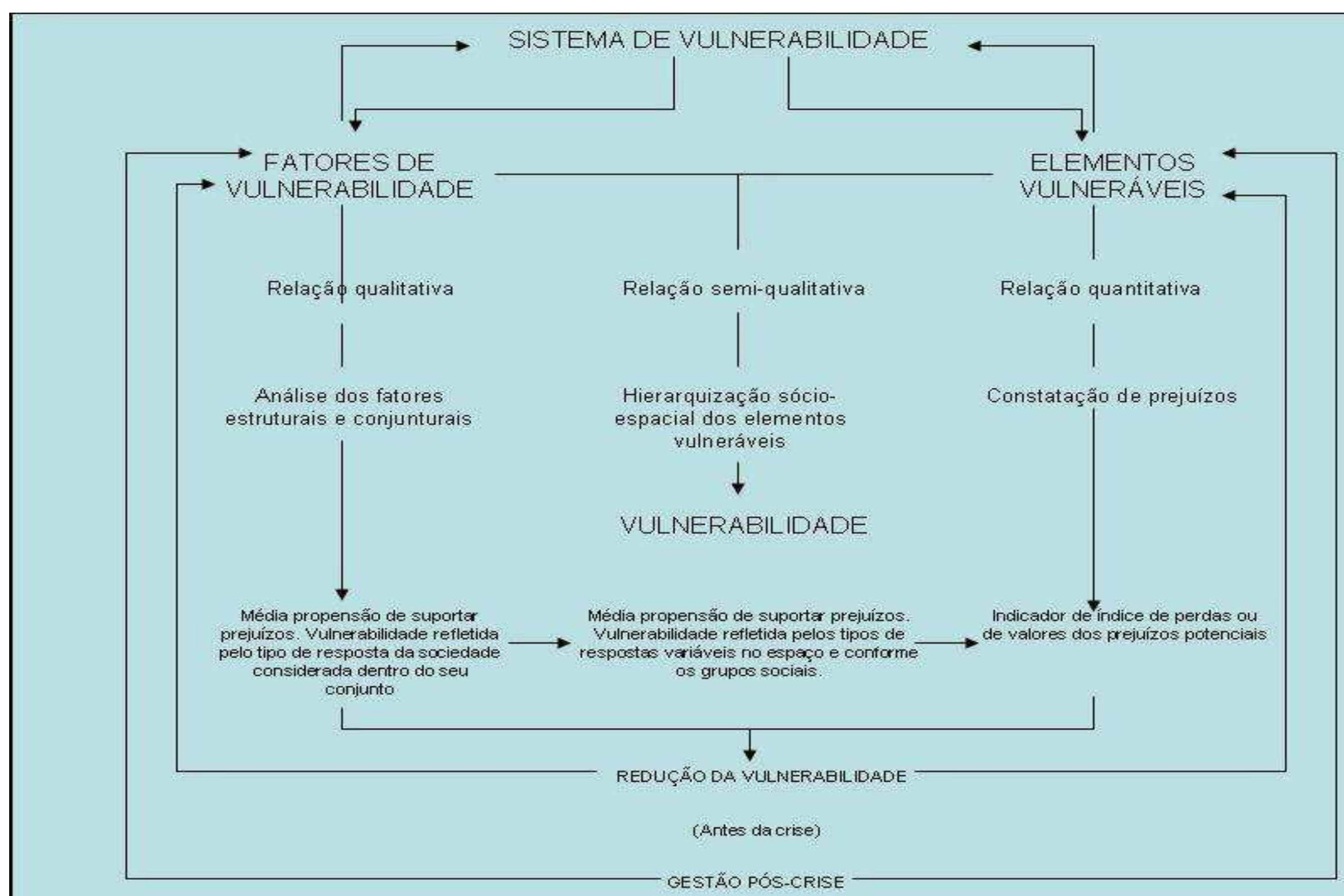

Fig.09 - Síntese das diferentes formas de vulnerabilidade e suas interrelações. Fonte: modificado de D'ÉRCOLE et al. (1995). 
Descrevendo inicialmente os sistemas de vulnerabilidade, passando pela análise dos fatores e dos elementos vulneráveis, a síntese do autor adentra na interpretação da própria vulnerabilidade, sendo que na relação qualitativa existe uma média propensão de se superar os prejuízos por parte da sociedade como um todo.

$\mathrm{Na}$ análise semi-qualitativa, existe uma média propensão caracterizada pelas respostas diferenciadas no espaço geográfico, dependendo em grau conforme os tipos sociais atingidos.

A relação quantitativa direciona sua análise para a somatória das perdas e dos prejuízos potenciais. As três relações acima requer, segundo o autor, uma análise mais aprofundada para se chegar à uma redução da vulnerabilidade, no que tange à necessidade de se avaliar a situação e a tomada de providências para se evitar as crises.

A teorização discutida acima pode perfeitamente ser aplicada às sociedades urbanas atuais, no que diz respeito aos tipos usuais de uso da terra, pois a vulnerabilidade ou fragilidade ambiental acabou se tornando um fator do cotidiano.

Diante do exposto, conclui-se que os impactos ambientais, principalmente os de caráter urbano, são fatores potencializadores que desencadeiam os processos morfogenéticos. Na cidade de Taboão da Serra, em função da irregularidade do terreno, esses processos instalam-se comumente nas encostas dos bairros de baixo padrão sócioeconômico.

Em relação ao uso da terra e a ação antrópica, Guerra \& Cunha (2001) abordam que a susceptibilidade dos solos à erosão estão ligados aos padrões das relações sociais de propriedade e com o acesso das diferentes classes sociais às técnicas de 
conservação do solo. Enquanto a classe alta dispõe de grandes áreas que lhe permitem manter a vegetação e preservar o solo, a classe de menor poder aquisitivo se "aglomera" e, ao aumentar a densidade populacional altera a capacidade de suporte do solo.

Partindo desse pressuposto, percebe-se que a esfera social tem um peso muito grande na instalação de sistemas vulneráveis. É importante salientar que a ocupação desordenada de encostas, antes de mais nada, é um problema de gestão urbana e de má distribuição de renda, passando também pela falta de recursos para uma melhor estruturação das habitações.

\subsection{Pesquisa Aplicada}

Sabendo-se da importância atual dos estudos ambientais e da aplicabilidade evidenciada pelo constante uso das geotecnologias em trabalhos de cunho geográfico, e ao mesmo tempo de sustentabilidade do meio-ambiente, iremos definir como método de abordagem a geocodificação dos sistemas ambientais e antrópicos dentre eles o relevo, rede hidrográfica, cobertura vegetal e uso do assoalho ou sítio urbano.

A análise geográfica que será desenvolvida no trabalho terá como base a proposta metodológica definida por A. Libault (1971), onde o autor incorpora ao universo da pesquisa geográfica "4 níveis ou fases de pesquisa: Compilatório, Correlatório, Semântico e Normativo" (Fig.10) e que encontra-se resumido no seguinte fluxograma: 
Fig. 10: 4 NÍVEIS DA PESQUISA GEOGRÁFICA



Fonte: Elaborado pelo autor, com base em Libault (1971) 
A fase I (compilatória de documentação) consistiu na coleta e na posterior compilação dos dados. Segundo Libault quando se coleta dados, estes devem ser separados de forma concisa (quais informações de fato relevantes) e principalmente utilizando-se da seletividade (quais informações chave), utiliza-se portanto uma seleção que objetiva sair da subjetividade em direção à objetividade.

Tais dados devem ser orientados no espaço (geográfico) e no tempo, sendo essenciais (Latitude/Longitude) como forma de localização dos processos. Um Banco de Dados tornou-se essencial para a compilação das informações.

A fase compilatória preconizada por Libault (1971), aplicarse-á na nossa pesquisa partindo da busca de dados como: informações históricas sobre a cidade, cartas temáticas préexistentes, dados sócio-econômicos e a base da pesquisa que foi apoiada pela análise temporal do uso da terra a partir de vôs fotogramétricos (ortofotos) em duas datas distintas 1962 e 2007.

Nesta fase utilizamos duas técnicas importantes para a elaboração da pesquisa sem incorrermos no risco de erros de interpretação: o primeiro apoiados na análise e interpretação de campo e o segundo nos serviços de gabinete. Dentro do nível compilatório obtivemos os dados de caráter essenciais (primários) e os de apoio (secundários).

\subsubsection{Dados primários:}

Esta fase foi efetuada através dos resultados da pesquisa de campo e da posterior confecção das cartas em gabinete. O trabalho de observação e levantamento de informações realizados em campo foi realizado em dois momentos: 
- Numa primeira incursão foi realizado o reconhecimento do município, nas sua área central e nas áreas periféricas, identificando os pontos mais problemáticos com relação ao uso e ocupação;

- Num segundo momento, que na verdade resultou em várias incursões ao município, caracterizou-se pela interpretação da dinâmica ambiental no município. Esta fase desenvolveu-se tendo como suporte para a utilização da base cartográfica e da localização na área de estudo dos principais pontos com suas coordenadas. Utilização de dados de GPS (Global Positioning System) para a orientação das fotos com relação às suas reais coordenadas geográficas;

\section{- CARTA BASE}

A base topográfica foi digitalizada e vetorizada a partir das cartas topográficas em escala 1:50.000 do IBGE, folhas SF-23-Y-V-VI-1 (Osasco) e SF-23-Y-V-VI-2 (São Paulo), com hidrografia, pontos cotados e curvas de nível de 20 metros de eqüidistância, contendo:

- Curvas de nível (com cotas e eqüidistâncias compatíveis com o propósito da pesquisa- $20 \mathrm{~m}$ );

- Rede de drenagem, composta pelos principais córregos Pirajussara e Poá;

- As cotas;

- Edificações e malha urbana;

- E a rede rodoviária. 


\section{- FOTOINTERPRETAÇÃo}

Utilizada para demarcar a área de estudo assim como os seus limites, como também para elaborar as cartas temáticas, realizou-se a fotointerpretação com o uso de 2 vôos da área de estudo, formando um mosaico que recobre toda a extensão do município, perfazendo aproximadamente $20,38 \mathrm{~km}^{2}$. Um vôo realizado no ano de 1962 pelo IBGE perfazendo um total de 5 fotos, que cobre a área (ortofotos no formato tif de números: $3889,3890,3921,3922,3923)$. Para o ano de 2007, utilizou-se 16 fotos também em formato tif (2325-2,23254,2326-1,2326-2,2326-3,2326-4,2341-2,2341-4,2342$1,2342-2,2342-3,2342-4,3315-1,3315-3,3331-3,3331-1)$.

Cartas temáticas resultantes:

\section{- CARTA CLINOGRÁFICA:}

Caracterizada pelo mapeamento das declividades e da geometria da área de estudo, esta carta utiliza classes de declividades com os intervalos apoiados nos estudos de Capacidade de Uso e Aptidão Agrícola de Ross (1994), embora não haja uso agrícola na área de estudo, buscou-se através da aplicação dos valores críticos da geotecnia correlacionar as declividades e sua geometria com o tipo de uso e ocupação assim como, esses valores podem indicar a atuação de processos erosivos, de escorregamentos e riscos de inundações.

Segundo Ross (1994) os intervalos de declividades podem ser classificadas nas seguintes categorias hierárquicas para efeito de interpretação:
Até $6 \%$ - MUITO FRACA
De 6 a $12 \%$ - FRACA
De 12 a 20\% - MÉDIA 
De 20 a $30 \%$ - FORTE

Acima de $30 \%$ - MUITO FORTE

Por característica do interpolador TIN (Triangulated Irregular Network) utilizado, a declividade está representada em graus de declividade e não em porcentagem. Os intervalos são diferentes mas com a aplicação do modelo de Ross (1994), chega-se ao mesmo resultado do ponto de vista do grau dos declives e da exposição das encostas em termos de porcentagem:

$0-1,72$

$1,72-3,43$

$3,43-6,84$

$6,84-11,31$

$11,31-16,70$

$16,70-90,00$

Para a confecção do mapa Clinográfico foi utilizado como base de apoio o sistema de tratamento digital oferecido pelo software ArcGis 9.2 e 9.3 em extensão de análise espacial.

\section{- CARTA geológica:}

O esboço geológico para a área de estudo utilizou como fonte de informações a carta elaborada pelo CPRM na escala 1:750.000 de 2006. Os tipos de rochas que ocorrem na área de estudo foram mapeadas utilizando como base a carta acima e outras mais antigas para efeito de comparação, fazendo-se ajustes necessários. 


\section{- CARTA HIPSOMÉTRICA:}

Constitui-se na representação das altitudes da área de estudo, representada na escala de $1: 10.000$, de $740 \mathrm{~m}$ até $880 \mathrm{~m}$ de altitude. identifica o entalhe das bacias hidrográficas locais e seu trabalho erosivo na construção das áreas de várzea e a identificação das vertentes. Através da carta hipsométrica visualiza-se o direcionamento do relevo em direção á bacia do rio Pinheiros à NE.

\section{- REDE HIDROGRÁFICA:}

Foi obtida através da carta base e resume-se como sendo uma carta que juntamente com a clinográfica e a hipsométrica dá suporte para a interpretação dos processos morfogenéticos que atuam na área. Caracterizado por uma rede hidrográfica bastante urbanizada, possui como principais cursos os Córregos Pirajussara e Córrego Poá, tributários do Rio Pinheiros.

Tais cartas temáticas foram utilizadas como apoio para a elaboração de um documento cartográfico (carta de uso da solo I e II) apoiados num Banco de Dados Geográfico que foram desenvolvidos no software ARCGis nas versões 9.2 e 9.3 .

\section{- DADOS CLIMÁTICOS:}

Os dados climáticos utilizados na identificação das características do município foram principalmente aqueles relativos à pluviosidade.

Os dados pluviométricos utilizados são oriundos de 2 estações próximas à área de estudo, a Estação da Cidade Universitária (E3-251) e a Estação Butantã-CGE. A dificuldade de obtenção de dados nos levou a analisar 3 períodos com um intervalo entre eles. De 1974 a 1982, de 1983 a 1992 e de 2000 a 2005. Para a representação dos dados elaborou-se para cada ano um gráfico 
de barras, para melhor visualização. Nos intervalos pesquisados o ano mais chuvoso foi o de 1983 com aproximadamente 2.174,5 $\mathrm{mm}$, excedendo sobremaneira a média anual de $1.330 \mathrm{~mm}$. Em contrapartida, o ano menos chuvoso foi 1985 com aproximadamente $882,4 \mathrm{~mm}$, este ano representa uma queda nos índices de chuva que iniciou-se em 1984 com 922,3.

\subsubsection{Dados secundários:}

- Correspondeu na pesquisa pela busca da referência bibliográfica adequada, como também de trabalhos referentes à área de estudo. Adiciona-se a estes dois, os dados considerados técnico-metodológicos oriundos da interpretação das cartas temáticas pré-existentes.

- Levantamento de Campo:

Destinados a confrontar e controlar as informações obtidas na fotointerpretação e referências bibliográficas que foram essenciais na determinação dos resultados a serem alcançados. Esses levantamentos ocorreram oriundos da necessidade de se confirmar informações anteriormente levantadas que tiveram como base, cartas pré-existentes: hidrográficas, hipsométricas, geomorfológicas, e de uso e ocupação, com dados cartográficos oficiais como vôos fotogramétricos o que nos possibilitou identificar através da elaboração de nosso material cartográfico os avanços da ocupação humana através da horizontalização da cidade.

A fase II (correlação das informações) consistiu na verificação da ocorrência de certos fenômenos que são repetitivos ou não na escala espacial de análise. Este diagnóstico se dá pelo fator de comparação, observando se tais processos ocorrem em outros locais, definindo assim um tipo (morfologia) orientando se 
dentre esses fatores existem variáveis $q$ e demonstrem caracterizar uma certa regularidade nas manifestações destes fenômenos. Como por exemplo, a ocupação das margens dos córregos eliminando a mata ciliar.

Nesta fase os dados colhidos foram separados, analisados e reordenados por fases de ocorrências, foram avaliados os dados pluviométricos, de ocorrência de eventos, e uso do solo (edificação). O uso de overlays ou seja, de sobreposição de cartas temáticas será a base de apoio nesta fase onde, as variáveis (cobertura vegetal, pluviometria, geologia e uso da terra) foram digitalizadas, tratadas e trabalhadas de forma a constituir no material resultante da pesquisa.

A fase lll (nível semântico) relacionado à localização, compreensão e interpretação precisa dos problemas que levaram à elaboração da pesquisa, tendo como objetivo organizar os elementos dentro de uma problemática maior. Esta fase caracterizou-se por dar ênfase à análise e à sintetização que, segundo Libault, tem como aspecto maior a aplicação pelo pesquisador de seu conhecimento geográfico e pela sua experiência correlacionada com o cálculo (Banco de Dados).

A fase IV (nível normativo) tem relação com a criação de modelos, o que não é objetivo final da presente pesquisa. De fato o que mais importa é o aproveitamento da mesma em termos de aplicação dos resultados. A comparação entre duas épocas diferentes, no que concerne à evolução urbana do município e a interpretação dos impactos dessa evolução sobre o sítio urbano é a característica principal da pesquisa, a modelização, objetivo do nível normativo, caracteriza-se na pesquisa pela elaboração das duas cartas de uso da terra em cada época, demonstrando a evolução da ocupação humana e seus resultados, sejam eles positivos ou negativos. 
Embora nossa preocupação esteja pautada na elaboração de um estudo técnico-científico, cabe ao poder público utilizar-se de tais estudos como subsídio técnico, visando um melhor planejamento territorial numa tentativa de re-estruturar a política de ocupação do assoalho urbano da área em questão.

Importa também contribuir para tornar a prática da cartografia ambiental como ferramenta voltada ao bem-estar social. 


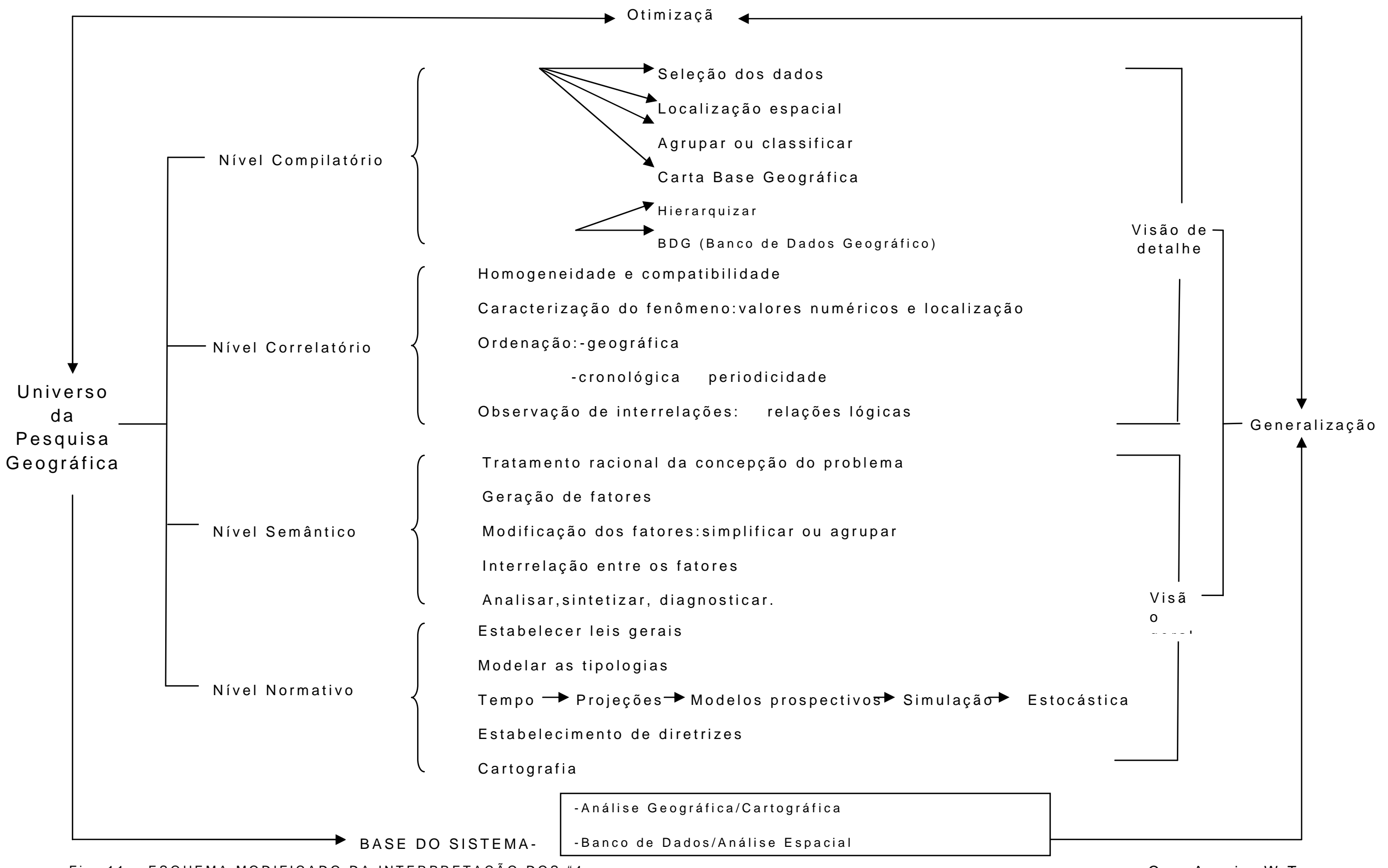

Fig. 11 - ESQUEMA MODIFICADO DA INTERPRETAÇÃO DOS "4

NÍVEIS DA PESQUISA EM GEOGRAFIA" SEGUNDO LIBAULT (1971) 
Fig.12 - Os níveis de procedimentos da pesquisa em Geografia: LIBAULT,1971.

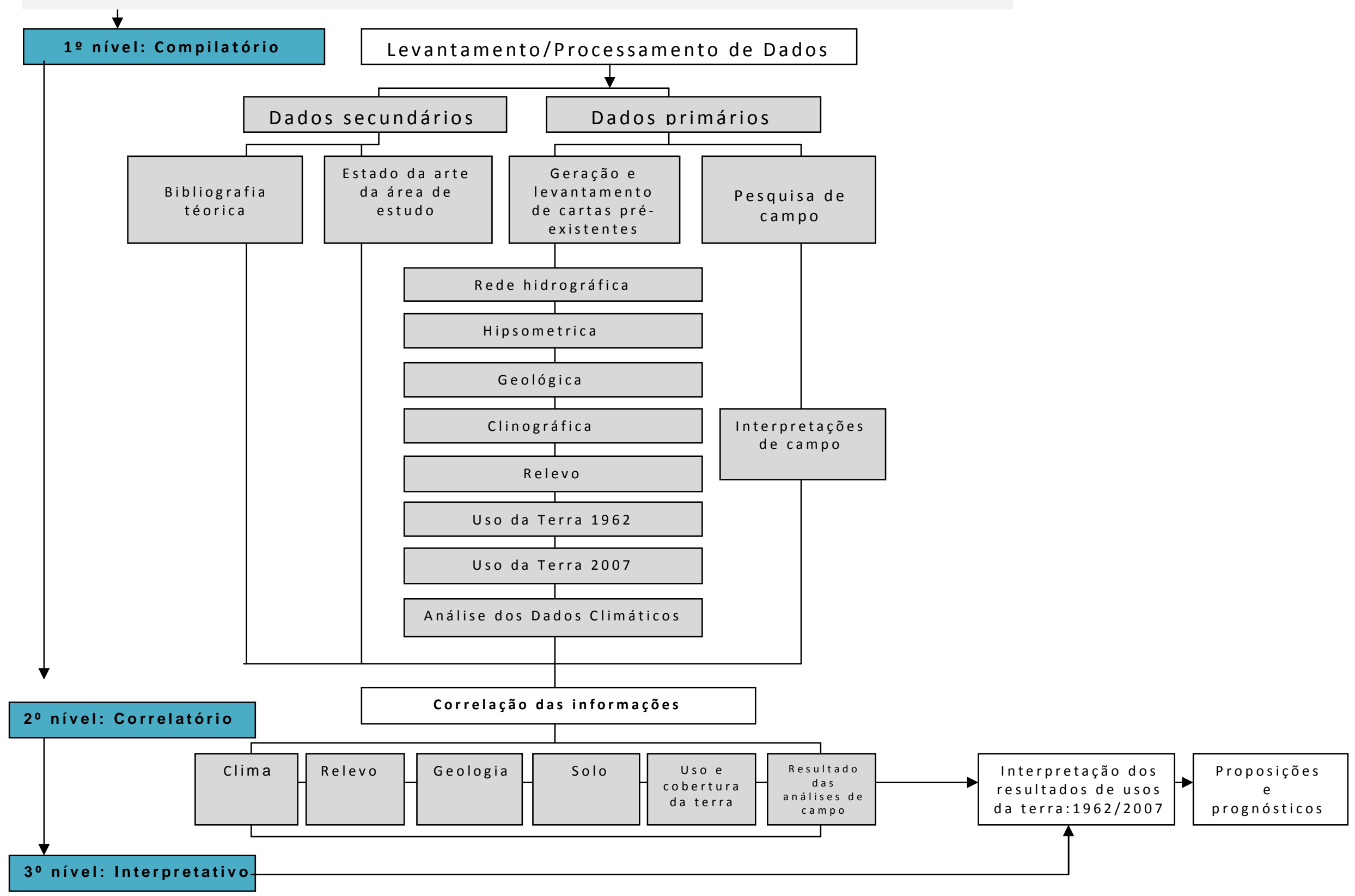


6. INSTRUMENTAL TÉCNICO DE ANÁLISE Produtos Gráficos e Cartográficos resultantes 


\subsection{Dados Climáticos}

A distribuição dos totais de chuva na RMSP são interpretadas a partir de dados obtidos em postos ou estações meteorológicas localizadas próximas a Taboão da Serra, pois, o município é desprovido de postos de observações e coletas, principalmente de pluviosidade.

A indisponibilidade de dados referentes às normais de chuva especificamente do município de Taboão da Serra, levounos na pesquisa a utilizar os dados referentes ao Banco de Dados do DAEE (Departamento de Águas e Energia Elétrica) relativo à estação meteorológica localizada no campus do Butantã da Universidade de São Paulo (E3-251) abrangendo os anos de 1974 a 1992, e a estação localizada no Butantã da CGE (Centro de Gerenciamento de Emergências) nas vizinhanças da cidade de Taboão da Serra.

O posto do Butantã serviu-nos como mais um parâmetro de análise pluviométrica que abrange as áreas próximas à cidade e que tem como base dados que vão do ano 2000 ao ano de 2005 .

Os eventos que mais importam no trabalho são àqueles que ocorrem na estação das chuvas, principalmente no período do verão. Compilamos de início as normais pluviométricas dos anos de 1974 a 1992, disponíveis no posto da Cidade Universitária de prefixo (E3-251), 23⒊' de Latitude Sul e 46 44' de Longitude Oeste. Este posto de observação pluviométrica está a 790 metros de altitude.

Um segundo grupo de dados de totais pluviométricos abrange os anos de 2000 a 2006, armazenados a partir do posto pluviométrico do CGE (Centro de Gerenciamento de Emergências) localizado no bairro do Butantã, delimitado pelas coordenadas de $23^{\circ} 33^{\prime}$ de Latitude Sul e $46^{\circ} 43^{\prime}$ de Longitude Oeste. 
A partir da avaliação dos dados pluviométricos, podemos diagnosticar o maior ou menor impacto sobre a superfície pois com o avanço da urbanização tem-se uma mudança nos padrões das variáveis climáticas: pluviosidade, temperatura por exemplo. A chuva neste caso exerce papel importante como agente desencadeador de processos morfodinâmicos (WOLMAN \& MILLER, 1974; MILDNER, 1982; HORTON,1945; WILSON, 1968).

O clima é um importante fator natural que exerce influência direta sobre o elemento pluviosidade. O conceito genético de Clima, elaborado por Sorre (1951) apud Tarifa (1974), o qual além de trabalhar com o conceito genético do clima, introduz a noção de ritmo e sucessão dos tipos de tempos é um importante conceito que explica as variações de espaço-tempo da distribuição das chuvas na RMSP, já que segundo o autor o Clima é: "o ambiente atmosférico constituído por uma série de estados da atmosfera, ou em outras palavras pelas suas sucessões habituais de estados atmosféricos".

Nota-se portanto, a visão habitual de que o Clima é na verdade uma constante, e que a pluviosidade é um estado genético dependente das variações momentâneas do tempo meteorológico. Entende-se também que a pluviosidade, ao contrário da temperatura, não é contínua no espaço e no tempo, levando-se em consideração a escala de análise.

Os sistemas meteorológicos que atuam sobre o Brasil, partem principalmente da ação do oceano Atlântico. As correntes de sul que são das mais atuantes, são geradas pelo anticiclone, que são comumentes designadas de "correntes perturbadas de leste" ou ondas de leste. A Frente Polar Atlântica ${ }^{14}$ produz essencialmente

14 Atribui-se à FPA o caráter de peça principal reguladora dos mecanismos de circulação sobre o Brasil, durante todo o ano. (SERRA, 1945 e MONTEIRO 1969) apud Aouad (1978). 
efeitos pluviais, atravessando o território brasileiro no sentido sul/norte.

Em Taboão da Serra, localizada na grande RMSP, a qual está classificada como área de atuação do regime tropical de altitude, tem como característica climática os efeitos da pluviosidade que se concentram nos meses de janeiro a março.

A umidade relativa, elemento meteorológico importante na distribuição das chuvas, aumenta consideravelmente nos meses de verão na RMSP. Como médias temos a distribuição espacial da ocorrência da umidade no estado de São Paulo de 1961 a 1990 (INMET,2009), indicando que a umidade na área que engloba a RMSP e portanto a cidade de Taboão da Serra encontra-se entre 75 e $80 \%$. 


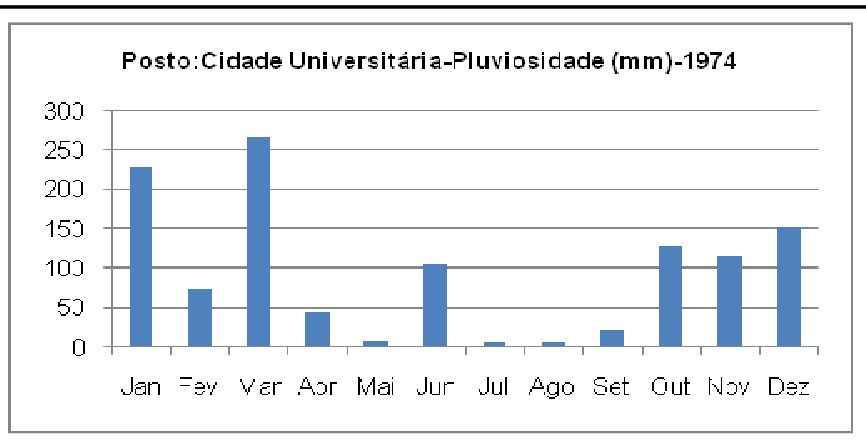

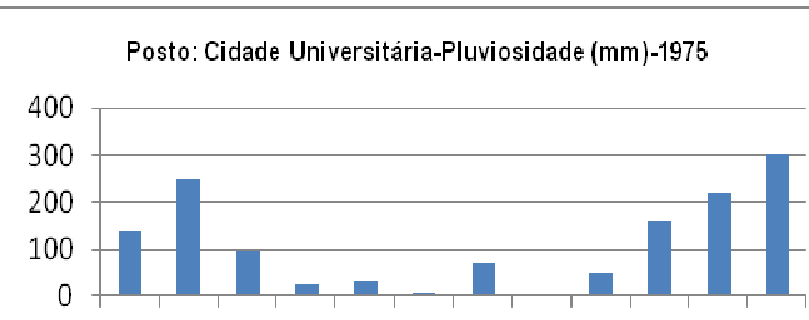

Jan Fev Mar Abr Mai Jun Jul Ago Set Out Nov Dez

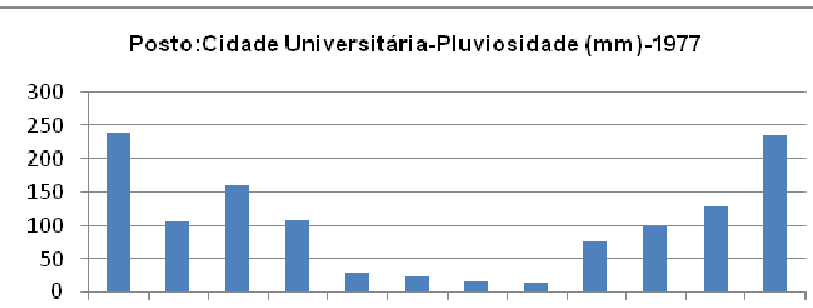

Jan Fev Mar Abr Mai Jun Jul Ago Set Out Nov Dez

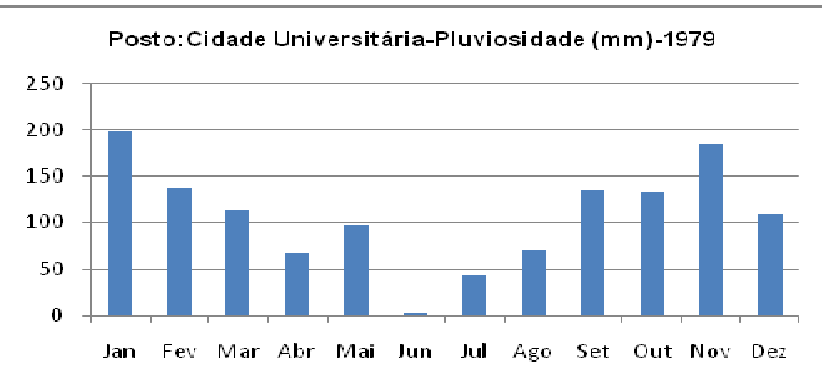

Posto:Cidade Universitária-Pluviosidade (mm)-1981

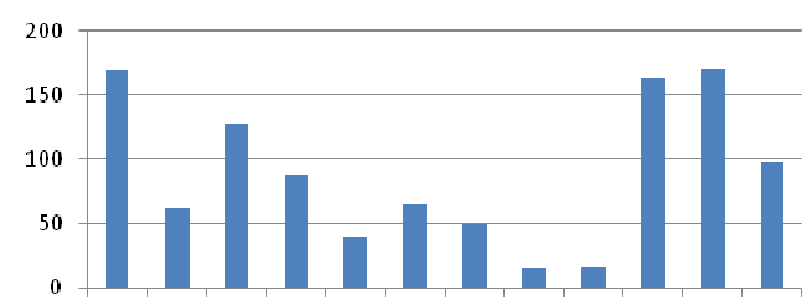

Jan Fev Mar Abr Mai Jun Jul Ago Set Out Nov Dez

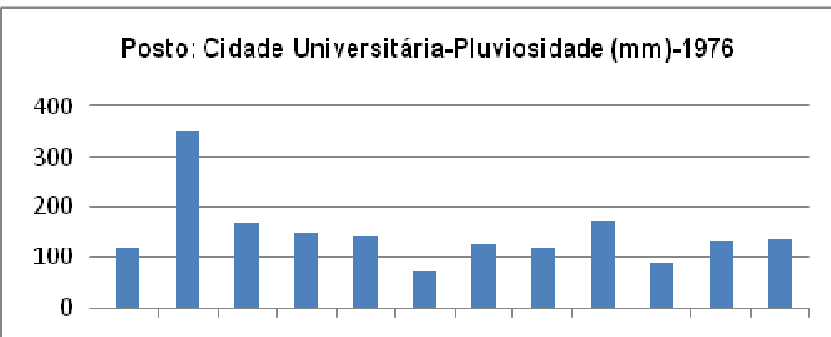

Jan Fev Mar Abr Mai Jun Jul Ago Set Out Nov Dez

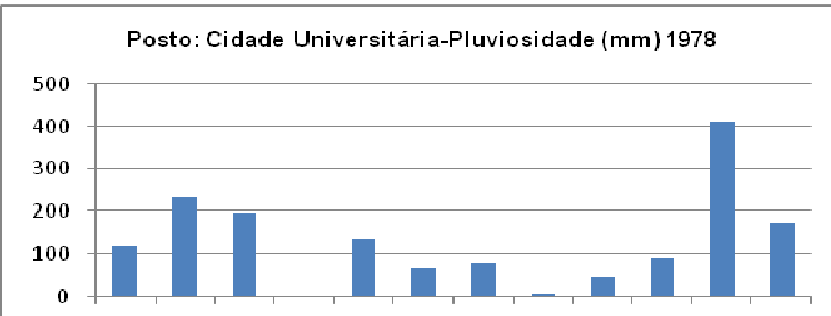

Jan Fev Mar Abr Mai Jun Jul Ago Set Out Nov Dez

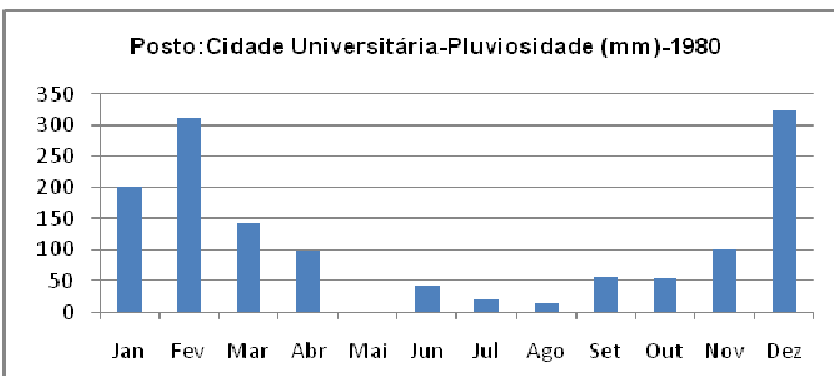

Jan Fev Mar Abr Mai Jun Jul Ago set Out Nov Dez

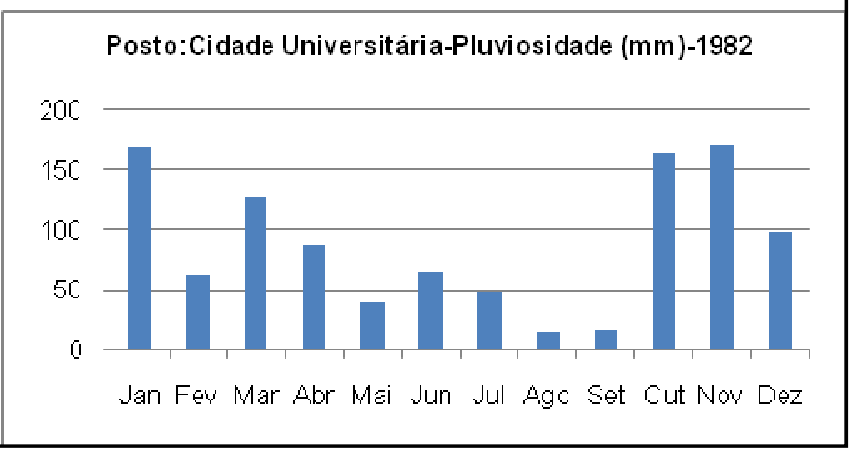

Fig.13 - Totais pluviométricos mensais- Posto Cidade Universitária/USP Período:1974 a 1982-DAEE- Departamento de Águas e Energia Elétrica). 


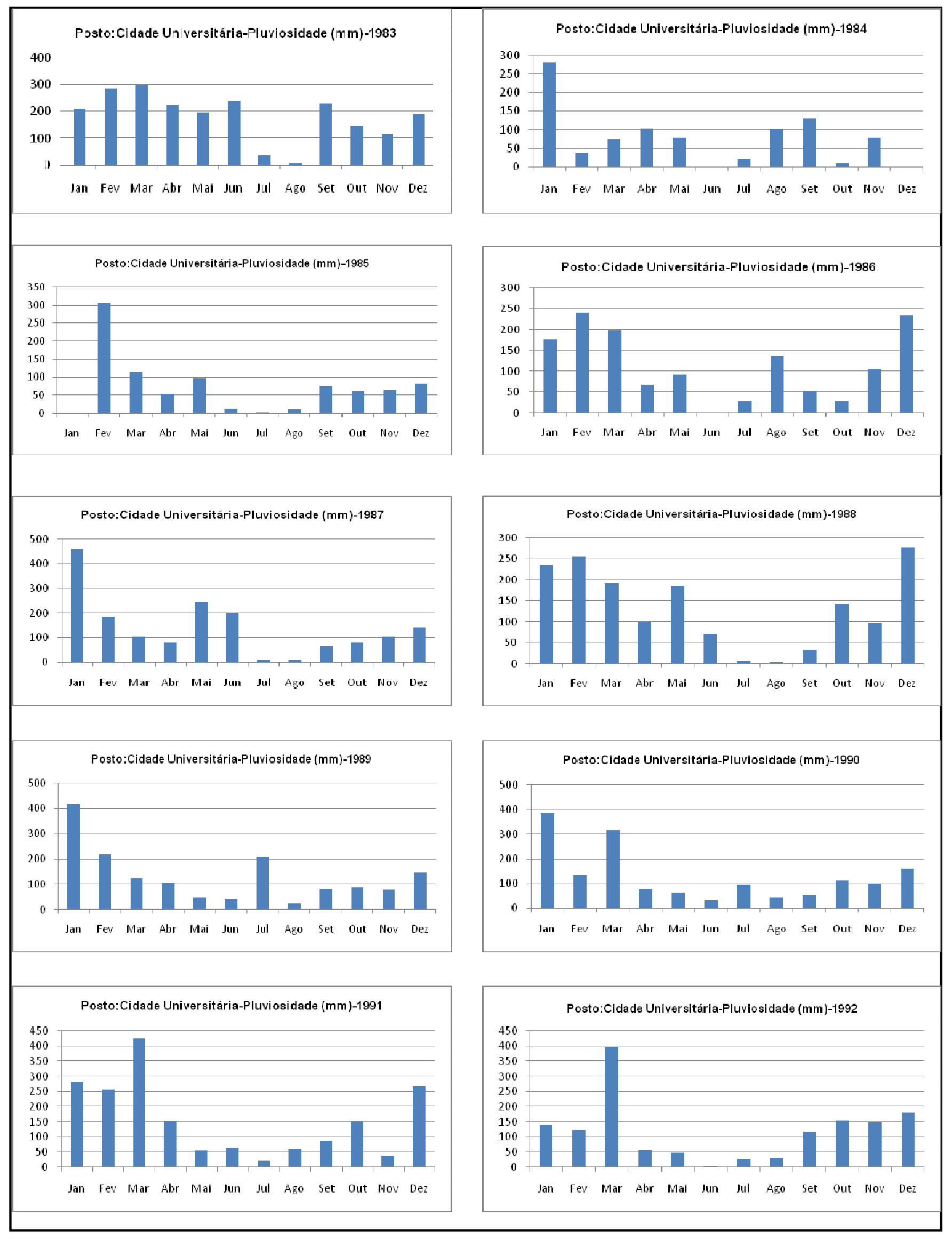

Fig. 14 - Totais pluviométricos mensais - Posto: Cidade Universitária/USP

- Períndn.1983 a 1992- MAFF (Menartamento de Ánulas e Fnerria Flétrical 


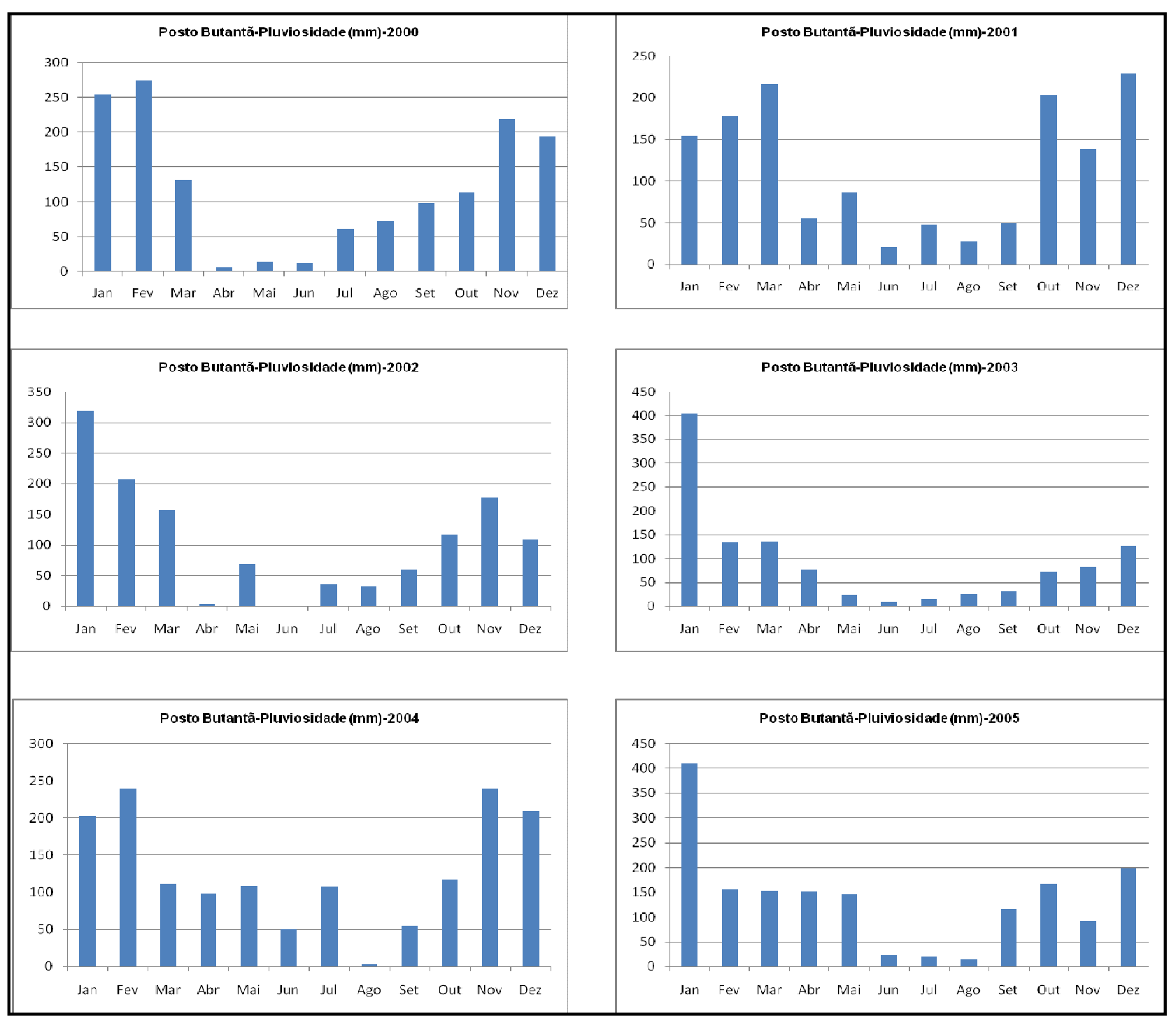

Fig. 15 - Totais pluviométricos mensais - Posto: Butantã - Período:2000 a 2005 - DAEE (Departamento de Águas e Energia Elétrica).

Os dados de chuvas utilizados aqui, abrangem um amplo período, fato este que se explica pela necessidade da análise do regime hídrico na cidade num espaço em que se deu a maior expansão da mesma, principalmente na década de 1970.

Nota-se que para os anos de 1974,1976 e 1978, o mês de junho mostrou-se bastante chuvoso, fato esse que é peculiar pois, normalmente no inverno os totais pluviométricos são baixos, sendo que as chuvas ocorrem em poucos dias desse mês, não ultrapassando os $10 \mathrm{~mm}$. 
Para o ano de 1974, o mês de junho marcou a ocorrência de $106,4 \mathrm{~mm}$, correspondendo a um fato atípico. Segue também como períodos atípicos, 1976, com junho $(72,3 \mathrm{~mm})$, julho $(126,5 \mathrm{~mm})$, 1978 com junho $(68,6 \mathrm{~mm})$ e julho $(79,7 \mathrm{~mm})$.

Observando os meses tradicionais da ocorrências de chuvas e até de tempestades, período representado pelos meses de verão, sobressai-se também o ano de 1976, em fevereiro ocorreu excepcionais $(350,1 \mathrm{~mm})$.

$\mathrm{Na}$ década de 70 o ano mais chuvoso foi o de 1978 com aproximadamente $1.957 \mathrm{~mm}$. A crescente urbanização e a cobertura do solo da cidade, gerou a partir da década de 1980 impactos negativos, principalmente na vazão dos córregos e na dificuldade da percolação das águas pluviais.

Os totais pluviométricos na década de 1980 e 1990 por si só não podem explicar as constantes enchentes e quedas de barreiras, mas elas sim,, podem ser associadas à variável compactação e adensamento urbano para compreendermos os problemas ambientais que se instalaram atualmente no município.

Esta característica torna-se mais evidente quando ocorrem eventos da magnitude das tempestades de verão, como também pela caracterização de um mês bastante chuvoso, como ocorreu em janeiro de 1987 com 480,2 mm. 
Tabela 04- Totais pluviométricos mês/ano-Período 1973/1980.(Cidade Universitária-E3-251)

\begin{tabular}{|c|c|c|c|c|c|c|c|}
\hline$A N O$ & 1974 & 1975 & 1976 & 1977 & 1978 & 1979 & 1980 \\
\hline MESES & $(m m)$ & $(m m)$ & $(m m)$ & $(m m)$ & $(m m)$ & $(m m)$ & $(m m)$ \\
\hline Janeiro & 229,1 & 138,8 & 120,8 & 240,6 & 118,6 & 198,4 & 201,6 \\
\hline Fevereiro & 75,8 & 249,1 & 350,1 & 107,1 & 234,6 & 138,3 & 312,3 \\
\hline Março & 267,8 & 96,4 & 169,2 & 160,1 & 196,9 & 112,6 & 144,1 \\
\hline Abril & 44,8 & 21,9 & 149,2 & 107,7 & 0,7 & 68,3 & 100,3 \\
\hline Maio & 6,8 & 31,4 & 144,2 & 29,7 & 134,8 & 97,9 & 2,8 \\
\hline Junho & 106,4 & 5,6 & 72,3 & 24,1 & 68,6 & 3,1 & 44,5 \\
\hline Julho & 5,1 & 71,1 & 126,5 & 17,2 & 79,7 & 43,4 & 21,5 \\
\hline Agosto & 5,7 & 1,2 & 118,2 & 15,6 & 6,2 & 70,3 & 16 \\
\hline Setembro & 22,5 & 49,2 & 171,3 & 77,6 & 45,7 & 134,7 & 56,5 \\
\hline Outubro & 128,9 & 160,4 & 88,1 & 101,6 & 93,1 & 134,6 & 56 \\
\hline Novembro & 115,7 & 221,6 & 132,4 & 130 & 411 & 185,4 & 101,3 \\
\hline Dezembro & 152 & 302,9 & 137,9 & 234,8 & 172,8 & 109,2 & 322,6 \\
\hline Total & $1.160,6$ & $1.349,6$ & $1.780,2$ & $1.146,1$ & $1.562,7$ & $1.296,2$ & $1.379,5$ \\
\hline
\end{tabular}

Tabela 05- Totais pluviométricos mês/ano-Período 1981/1988.(Cidade Universitária-E3-251)

\begin{tabular}{|c|c|c|c|c|c|c|c|c|}
\hline$A N O$ & 1981 & 1982 & 1983 & 1984 & 1985 & 1986 & 1987 & 1988 \\
\hline MESES & $(m m)$ & $(m m)$ & $(m m)$ & $(m m)$ & $(m m)$ & $(m m)$ & $(m m)$ & $(m m)$ \\
\hline Janeiro & 168,3 & 255,5 & 210,1 & 281,1 & - & 176,9 & 460,2 & $\overline{234,2}$ \\
\hline Fevereiro & 62,8 & 336,8 & 286,5 & 38 & 305,2 & 241,4 & 186,4 & 256,3 \\
\hline Março & 127,7 & 148,4 & 298,7 & 74,7 & 114,2 & 199,1 & 103,1 & 191,8 \\
\hline Abril & 87,5 & 43,7 & 224,6 & 104,8 & 54,5 & 68,7 & 78,7 & 99,5 \\
\hline Maio & 39,7 & 60,4 & 193,5 & 78,1 & 97,1 & 92,8 & 244,9 & 185,2 \\
\hline Junho & 64,7 & 209,7 & 238 & 0,6 & 13,1 & 2,3 & 200,5 & 71,2 \\
\hline Julho & 49 & 50,5 & 36,4 & 21,4 & 2,7 & 29,8 & 9,3 & 6,5 \\
\hline Agosto & 14,4 & 74,2 & 7,4 & 102,3 & 11,6 & 138,7 & 9,6 & 4,7 \\
\hline Setembro & 16,2 & 12,4 & 228,8 & 131,6 & 76,5 & 52,5 & 66,5 & 32,8 \\
\hline Outubro & 163,3 & 180,2 & 146,1 & 11,2 & 60,8 & 28,9 & 79,1 & 141,8 \\
\hline Novembro & 170,4 & 149,3 & 116,5 & 78,5 & 64,6 & 104,8 & 104,9 & 97,3 \\
\hline Dezembro & 98,2 & 254,2 & 187,9 & - & 82,1 & 234,4 & 141,4 & 279,3 \\
\hline Total & $1.062,2$ & $1.775,3$ & $2.174,5$ & 922,3 & 882,4 & $1.370,3$ & $1.684,6$ & $1.600,3$ \\
\hline
\end{tabular}


Tabela 06- Totais pluviométricos mês/ano-Período 1989/1993.(Cidade Universitária- E3-251)

\begin{tabular}{l|rrrr}
\hline ANO & \multicolumn{1}{|l}{1 1989 } & \multicolumn{1}{l}{1990} & \multicolumn{1}{l}{1991} \\
MESES & \multicolumn{1}{l}{$(\mathrm{m} m)$} & $(\mathrm{mm})$ & $(\mathrm{mm})$ & \multicolumn{1}{l}{$(\mathrm{mm})$} \\
& & & & \\
\hline Janeiro & 419,1 & 384,4 & 281,8 & 141,1 \\
Fevereiro & 219,5 & 134,4 & 255,3 & 120,1 \\
Março & 125,9 & 316,6 & 425,7 & 395,6 \\
Abril & 107,2 & 77,9 & 152,7 & 58,8 \\
Maio & 50,5 & 61,9 & 54,6 & 49,1 \\
Junho & 43,4 & 33,7 & 66,4 & 5,3 \\
Julho & 209,7 & 94,5 & 22,2 & 26,5 \\
Agosto & 24,8 & 40,1 & 61,1 & 31,8 \\
Setembro & 82,5 & 53,7 & 86,7 & 118,5 \\
Outubro & 88,6 & 112,9 & 149,1 & 155,6 \\
Novembro & 80,6 & 98,7 & 39,1 & 148,8 \\
Dezembro & 148,1 & 158,2 & 268,9 & 2,3 \\
\multicolumn{1}{c}{ Total } & $\mathbf{1 . 5 9 9 , 9}$ & $\mathbf{1 . 5 6 7 , 0}$ & $\mathbf{1 . 8 6 3 , 6}$ & $\mathbf{1 . 4 3 3 , 5}$ \\
\hline
\end{tabular}

Do total de anos que compõe a década de 1990, apenas o início foi computado para a avaliação das médias pluviométricas, a dificuldade de se conseguir os dados para o final desta década forçou-nos a finalizar a avaliação no ano de 1992 e iniciar novamente a partir do ano 2000.

Para os anos da década de 2000, verificou-se uma diminuição nos totais históricos, principalmente nos meses de inverno, em especial junho e julho, fugindo do padrão apenas o ano de 2004 com julho marcando $107,2 \mathrm{~mm}$.

A diminuição das médias de chuvas no inverno é um padrão conhecido e típico do domínio tropical, embora, em comparação com as normais da década de 70 e 80 , denote-se uma diminuição relativa dos padrões. 
A partir da interpretação visual dos pluviogramas, percebe-se num primeiro momento o caráter atípico dos anos de 2003 e 2005, no que se refere aos totais principalmente nos meses de janeiro dos respectivos anos. Este período historicamente é o mais chuvoso para a RMSP, chegando nestes dois períodos a apresentar uma concentração de $403 \mathrm{~mm}$ em janeiro 2003 e $410 \mathrm{~mm}$ em janeiro de 2005.

Tais concentrações num período curto provocam estresse, principalmente no que se refere à concentração das águas pluviais nos canais que eram naturais e que agora se apresentam "entubados". A construção de um piscinão pela prefeitura do município de São Paulo, na fronteira entre as duas cidades não conseguiu ainda, evitar de forma contundente as enchentes.

Em contrapartida aos meses mais chuvosos, nota-se que em 2002, houve pouca concentração de chuvas, o que já é natural essa falta de ocorrência nos meses de inverno, neste ano em junho a concentração ou total foi nulo. Este fator, gera dentre outros problemas, a queda extrema da umidade relativa do ar, aumentando a concentração também dos poluentes, derivados dos veículos e de algumas indústrias. 
Tabela 07- Totais pluviométricos mês/ano-Período 2000/2005. Posto: Butantã-CGE.

\begin{tabular}{|c|c|c|c|c|c|c|}
\hline $\mathrm{ANO}$ & 2000 & 2001 & 2002 & 2003 & 2004 & 2005 \\
\hline MESES & $(\mathrm{mm})$ & $(\mathrm{mm})$ & $(\mathrm{mm})$ & $(\mathrm{mm})$ & $(\mathrm{mm})$ & $(\mathrm{mm})$ \\
\hline Janeiro & 254,0 & 154,4 & 318,2 & 403,7 & 202,5 & 410,7 \\
\hline Fevereiro & 274,2 & 177,0 & 207,3 & 134,6 & 238,5 & 156,8 \\
\hline Março & 132,8 & 215,2 & 157,3 & 135,1 & 111,4 & 152,2 \\
\hline Abril & 6,4 & 55,1 & 3,0 & 76,1 & 98,1 & 150,3 \\
\hline Maio & 14,0 & 86,4 & 67,6 & 23,5 & 109,3 & 144,7 \\
\hline Junho & 12,4 & 21,1 & 0,0 & 7,9 & 49,9 & 22,4 \\
\hline Julho & 61,2 & 47,0 & 35,6 & 13,6 & 107,2 & 20,0 \\
\hline Agosto & 72,8 & 27,7 & 32,3 & 25,4 & 3,1 & 13,9 \\
\hline Setembro & 98,1 & 49,1 & 58,8 & 30,6 & 54,7 & 116,3 \\
\hline Outubro & 114,9 & 202,5 & 116,7 & 71,3 & 116,5 & 166,8 \\
\hline Novembro & 219,4 & 138,0 & 176,2 & 83,6 & 238,7 & 93,5 \\
\hline Dezembro & 195,3 & 229,2 & 108,1 & 125,3 & 208,4 & 197,2 \\
\hline Total & $1.455,5$ & $1.402,7$ & $1.281,1$ & $1.130,7$ & $1.538,3$ & 1644,8 \\
\hline
\end{tabular}



Fig. 16 - Normais pluviométricas e médias mensais no período de 30 anos na RMSP - 1961/1990.

Fonte: Inmet/2009. 
De acordo com as características do tipo climático dominante na região com localização na área tropical, percebe-se uma maior concentração das precipitações nos meses que correspondem ao intervalo das estações primavera/verão. Tal fato, procede como resultando de uma maior instabilidade atmosférica devido:

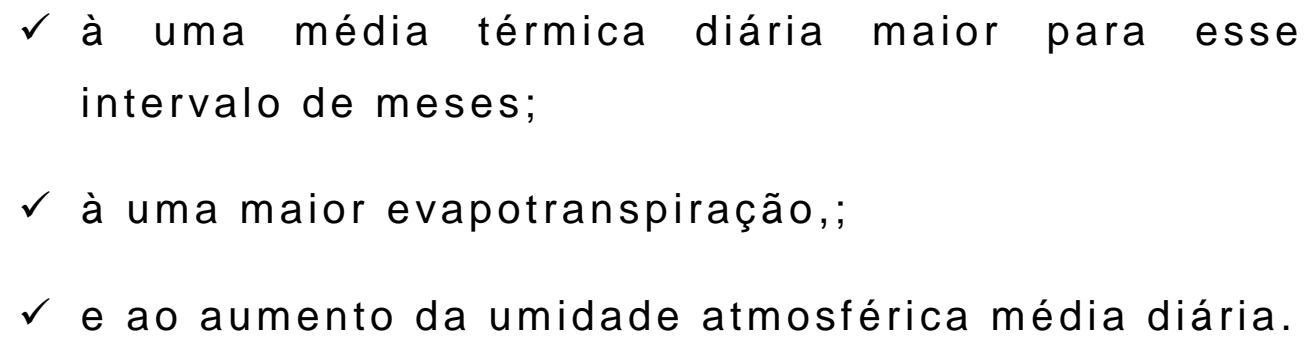
intervalo de meses;

$\checkmark$ à uma maior evapotranspiração,;

$\checkmark$ e ao aumento da umidade atmosférica média diária.

Com relação ao segundo tópico acima mencionado, faz-se necessário mencionar a ação dos micro climas principalmente na RMSP. Isto decorre devido ao adensamento do uso da terra urbana, como também pelo aumento da cobertura do solo pelo concreto e pelo asfalto, aliado ao fato do intenso tráfego e da descarga de materiais poluentes na atmosfera diariamente.

Tais combinações influenciam diretamente na e para a formação de tempestades de verão que por vezes inundam vias importantes tanto da capital paulista quanto do próprio município de Taboão da Serra.

Nos gráficos de chuvas podemos inferir as seguintes considerações:

$\checkmark$ Para o ano indicado na tabela (2000), os meses em destaque são fevereiro, novembro e dezembro, apresentando portanto pluviosidade acima das médias históricas para a área;

$\checkmark$ Para o ano indicado na tabela (2001), os meses com as mesmas características são março, outubro e dezembro; 


\subsubsection{Determinação de Período Seco (Segundo Bagnouls, e Gaussen, 1953).}

Os estudos voltados à caracterização de períodos denominados de "secos" ou "úmidos" ganharam importância a partir da proposta de F. Bagnouls e H. Gaussen em 1953 onde foi proposto um índice que indica em função da variação média anual da temperatura do ar e da precipitação, os meses secos e úmidos (GALVANI, 2008).

O Climograma de Gaussen é construído a partir dos valores de temperaturas médias mensais e dos respectivos totais de precipitação. Considera-se que $(P)$ é a precipitação e $(T)$ a temperatura do ar. Utilizamos a metodologia de Gaussen para calcular a existência ou não de períodos secos para o município de Taboão da Serra, identificando assim a presença de um período onde é praticamente nula a probabilidade de eventos pluviométricos como também de episódios extremos.

Seguindo a proposta metodológica, considera-se mês seco aquele que tenha como característica:

a) O registro de menos de $10 \mathrm{~mm}$ de chuva, a uma temperatura média inferior a $10^{\circ} \mathrm{C}$;

b) O registro de menos de $25 \mathrm{~mm}$ de chuva, a uma temperatura média compreendida entre 10 a $20^{\circ} \mathrm{C}$;

c) O registro de menos de $50 \mathrm{~mm}$ de chuva, a uma temperatura média compreendida entre 20 a $30^{\circ} \mathrm{C}$;

d) O registro de menos de $75 \mathrm{~mm}$ de chuva, a uma temperatura média superior a $30^{\circ} \mathrm{C}$.

Esta definição descontínua exprime-se, no entanto de forma contínua, por meio de uma reta indicando que mês seco é considerado aquele em que o total mensal das precipitações (quantificada em $\mathrm{mm}$ ) é igual ou inferior que o dobro da 
temperatura média (expressa em graus Celsius), ou seja, matematicamente expressa-se como sendo: , onde $P$ é a precipitação e T a temperatura do ar (GALVANI, 2008).

Para o município em estudo, as características pluvio-térmicas estão mais próximas das características da capital, mesmo a pluviosidade sendo um fenômeno descontínuo no espaço e no tempo.

Dentro desse contexto, o diagnóstico de um período considerado SECO, ocorre ao mesmo tempo nos três setores metropolitanos considerados.

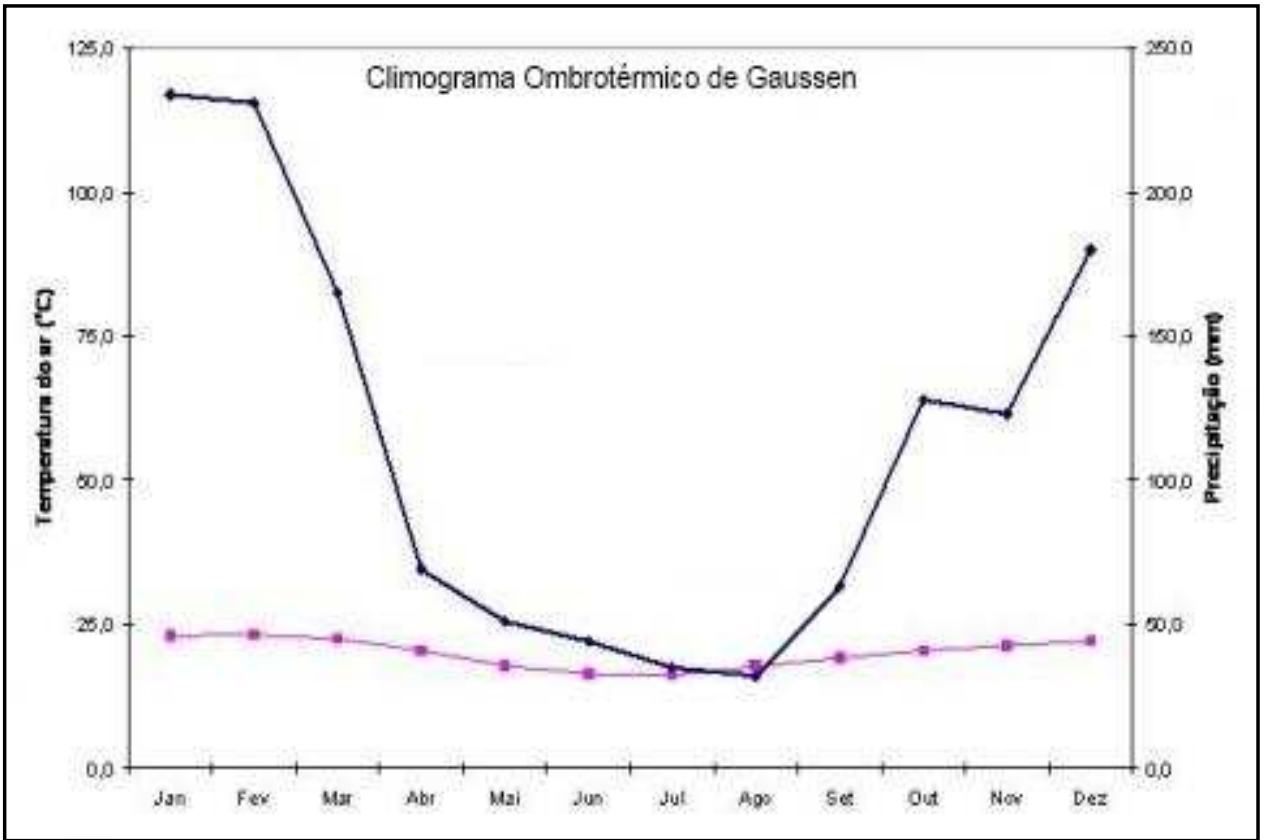

Fig. 17 - Exemplo de Climograma Ombrotérmico de GAUSSEN - Determinação de Período Seco para a cidade de São Paulo entre 1961/1990.

Fonte: GALVANI, E. 2008. 


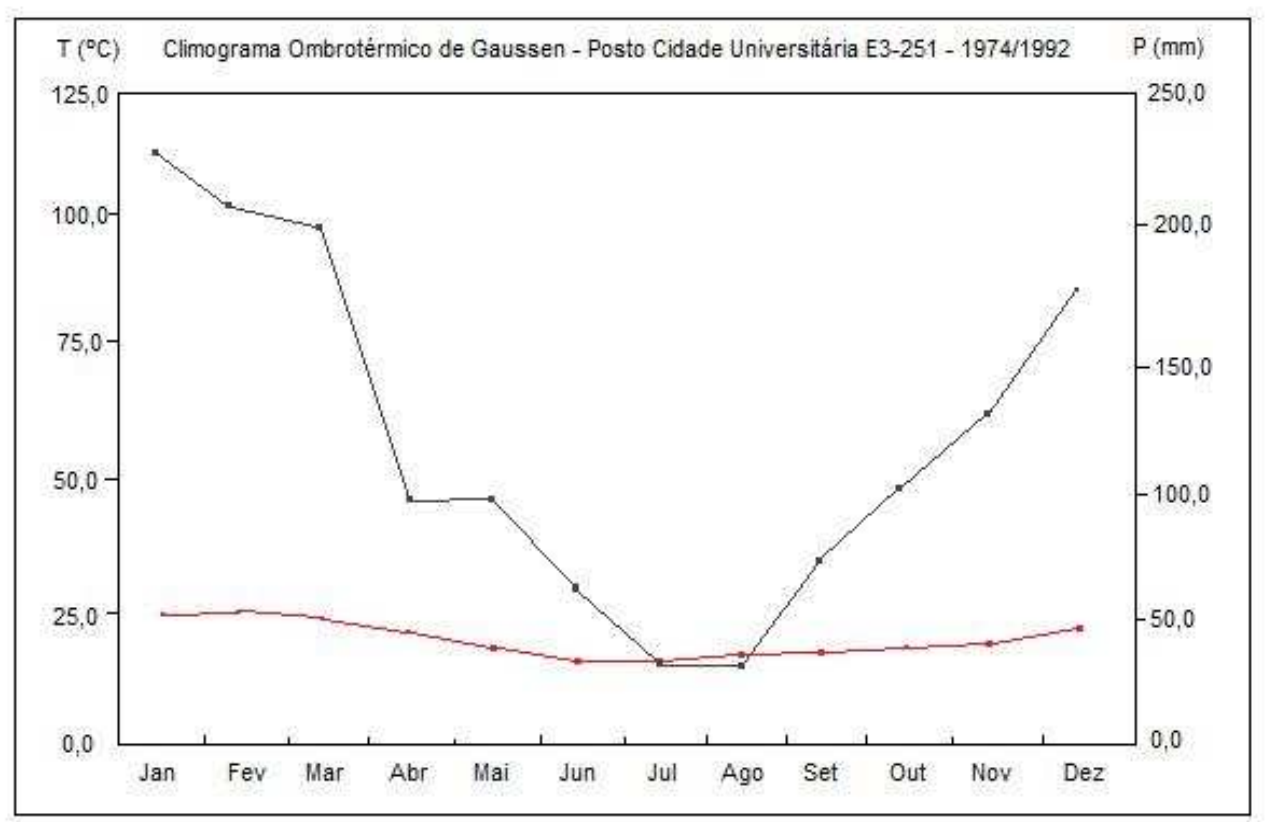

Fig.18 - Climograma Ombrotérmico de GAUSSEN Determinação de Período Seco - Posto Cidade Universitária E3-251- 1974/1992.

Elaboracão: Arauio.W.

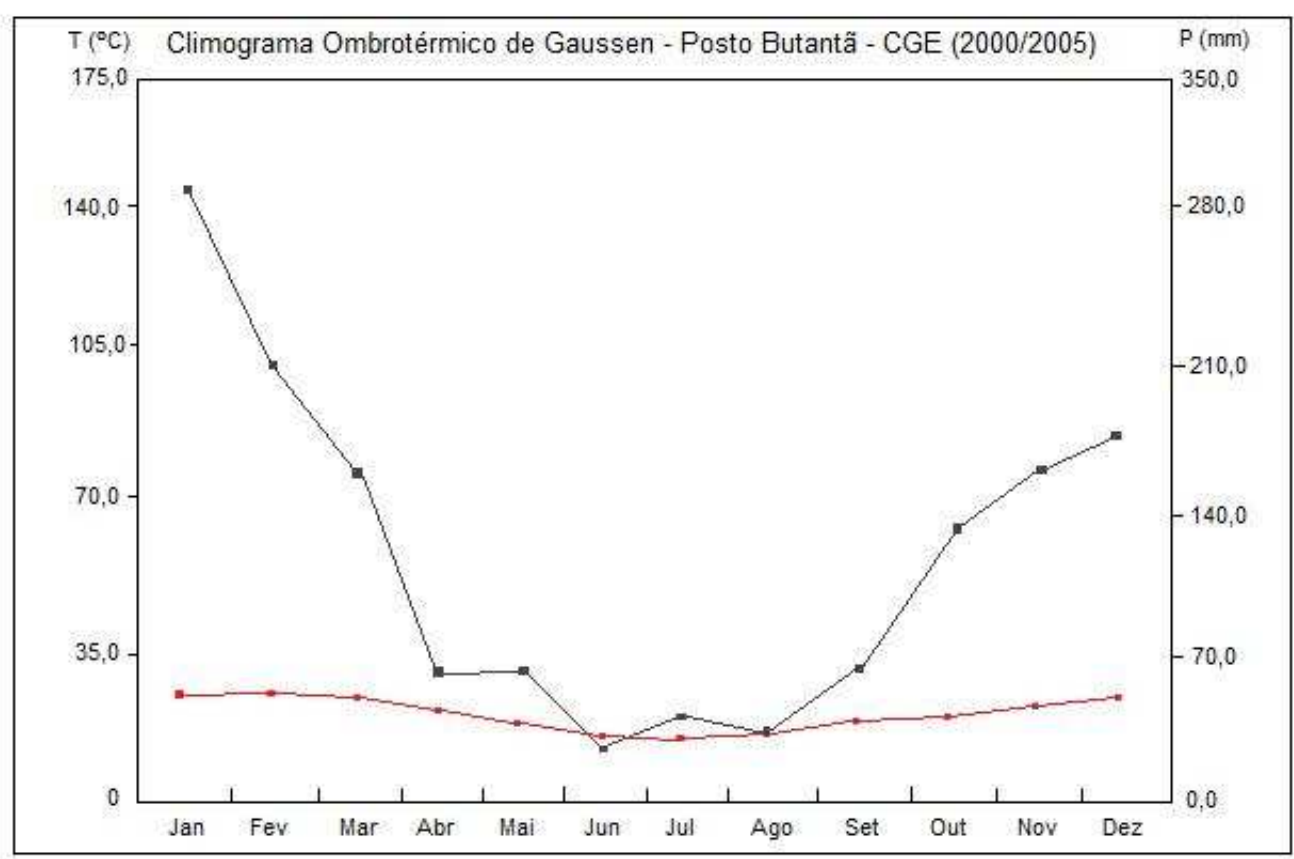

Fig.19-Climograma Ombrotérmico de GAUSSEN Determinação de Período Seco - Posto CGE/Butantã entre $2000 / 2005$.

Elaboração: Araujo,W.

Para Taboão da Serra, pode-se admitir, portanto, que o intervalo considerado como SECO, está representado entre Julho e Agosto 
no período entre 1974 a 1992 (Fig.18), onde as temperaturas estão abaixo de 25 graus Celsius e a pluviosidade cai a índices mínimos em comparação com os meses mais chuvosos.

a) Analisando o intervalo entre os meses de Julho/ Agosto no período de 1974 a 1992, percebe-se que os índices pluviométricos tiveram uma média de $39 \mathrm{~mm}$. Considerando a descontinuidade das chuvas e considerando também a proximidade dos dois municípios, temos em termos de temperatura uma média de 24 graus Celsius, isto coloca 0 município na seguinte classificação que apresenta mês considerado SECO: ( o registro de menos de $50 \mathrm{~mm}$ de chuva, a uma temperatura média compreendida entre 20 a 30 $\left.{ }^{\circ} \mathrm{C}\right)$.

b) No período compreendido entre os anos de 2000/2005 (fig.19) a média pluviométrica do mês mais seco Junho foi de $18 \mathrm{~mm}$, com as temperaturas médias de $25^{\circ} \mathrm{C}$, caracterizado pela aplicação da metodologia de Gaussen, o registro de menos de $50 \mathrm{~mm}$ de chuva, a uma temperatura média compreendida entre 20 a $30{ }^{\circ} \mathrm{C}$ como sendo o mês de Junho o período seco para este intervalo de anos;

Levando-se em consideração somente o diagrama ombrotérmico, a proposta diz que não é possível quantificar o quanto seco os meses representados, mas apenas indica-se que são meses secos, Galvani (2008). Por ser uma metodologia mais simples, ela pode fornecer de maneira simplificada uma caracterização do regime hídrico/térmico da região.

Considera-se que a presença de um intervalo ou mês caracterizado como seco, contribui na mudança de comportamento das atividades biológicas e genéticas da superfície (com impactos diretos nos solos), pois a saída de água é maior do que a entrada. 


\subsection{Carta Hipsométrica/MNT}

A carta hipsométrica, visualizada como um Modelo Numérico de Elevação-MNT (Fig.20), na prática revela a localização das principais áreas de encostas do município, onde percebe-se que no espigão da carta da próxima página (na cor verde) é onde estão localizados as maiores concentrações de construções de baixo padrão e os maiores contingentes populacionais, revelandose ser uma área ambientalmente problemática pela superutilização dos recursos naturais e modificação das estruturas físicas (eliminação dos fluxos hídricos, compactação do solo, poluição dos afluentes).

A carta hipsométrica é o resultado do cruzamento da carta topográfica de curvas de nível e de pontos cotados.

Tendo como referências essas duas variáveis, produziu-se através do interpolador de arestas denominado TIN (Triangulated Irregular Network), o modelo digital para a área do município, expandindo em poucos quilômetros além das fronteiras do mesmo, recurso que utilizamos para dar uma visão uniforme à carta hipsométrica através da modelagem digital de elevação. A área onde está assentada a rede hidrográfica, em especial, o Córrego Pirajussara, é o nível de base da área, com altitudes em média de $720 \mathrm{~m}$.

A carta hipsométrica baseada no Modelo Digital de ElevaçãoMDE, utiliza o recurso visual da modelagem em 3 dimensões para a representação do relevo local.

Com relação às altitudes e os locais onde estão representados as maiores elevações na cor "marrom", localizam-se in locus os últimos resquícios de vegetação do município se compararmos esta carta, com a carta de Uso da Terra (2007).

No setor Norte do município, mais precisamente nas áreas de divisas entre Taboão da Serra e São Paulo, percebe-se que são 
os locais mais elevados e que naturalmente são os divisores de águas. Devido à esta característica, as dificuldades de ocupação, como também, a presença de propriedades particulares extensas (condomínio Jardim Yolanda, Cemitério Vale dos Reis, Cemitério Parque Memorial Paulista) contribuíram de certa forma para a preservação das últimas áreas onde predominam as áreas florestadas. 


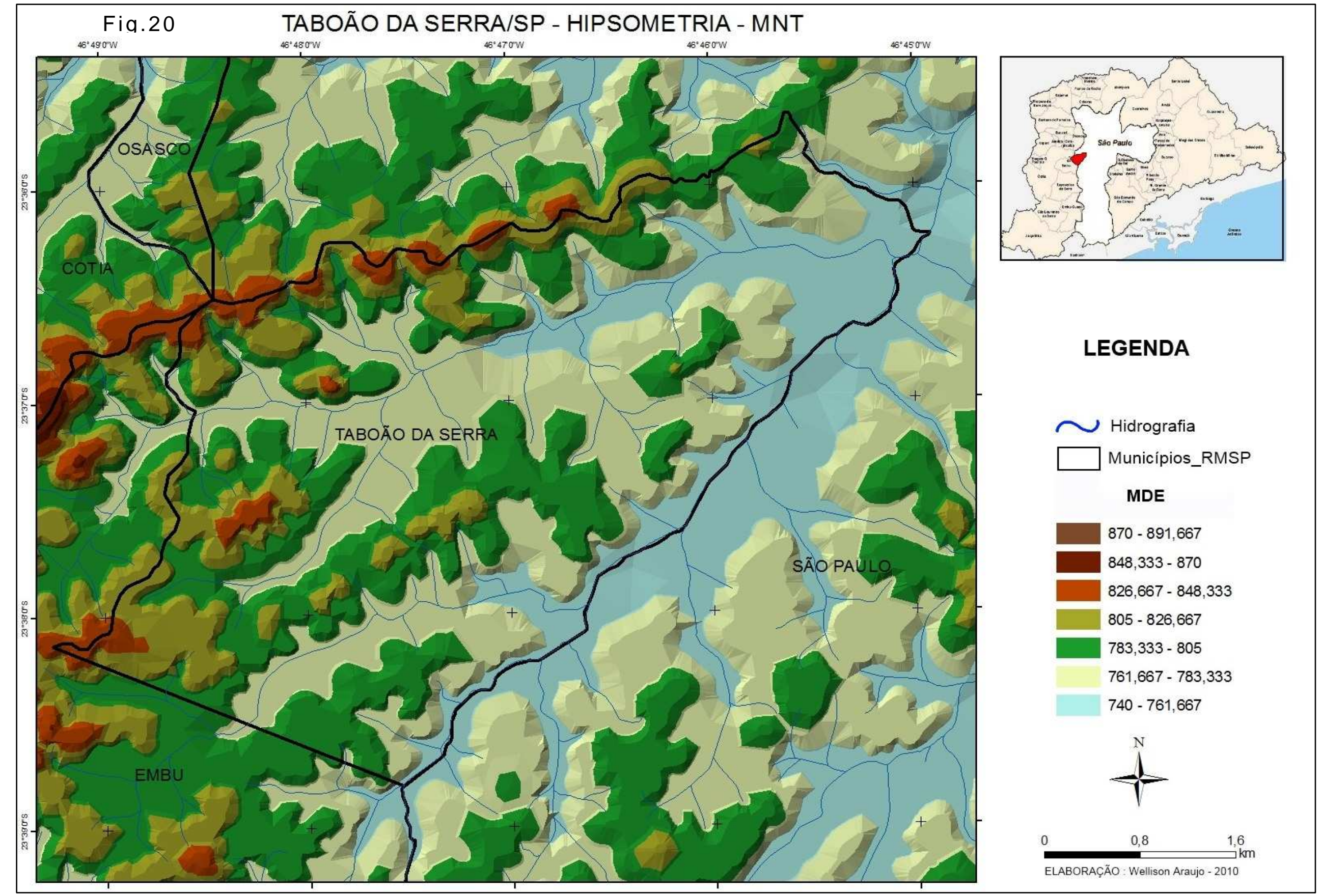




\subsection{Carta Hipsométrica}

As colinas são para a área do município as feições mais representativas (Fig.21).

Suas formas são diferenciadas e elas são mais presentes na parte sudoeste onde tem início o basculamento em direção NE (Rio Pinheiros).

Aparecem em todo a área, vertentes dos tipos côncavas e convexas, como também do tipo retilíneas. No setor SW do município elas se apresentam com maiores declives e altitudes.

As vertentes do tipo convexas são mais representativas e elas, a despeito de sua forma e da falta de proteção de cobertura vegetal, apresentam-se modificadas pela ocupação humana.

Esta característica altera o escoamento superficial difuso e modifica o sistema de infiltração das águas, já que neste tipo de vertente há uma menor tendência à infiltração.

Os processos atuantes nas vertentes côncavas, apresentam-se alterados, principalmente pela constante "cimentação" das mesmas como forma de estabilizar sua estrutura, o que provoca desequilíbrio dos processos naturais.

No setor SW, bairros cresceram ocupando este tipo de vertente (Parque São Judas, Parque Pirajussara, Parque Pinheiros, Jardim Saint Moritz etc.), esta situação explica em parte a problemática da modificação do escoamento superficial e das constantes enchentes nesses locais. 


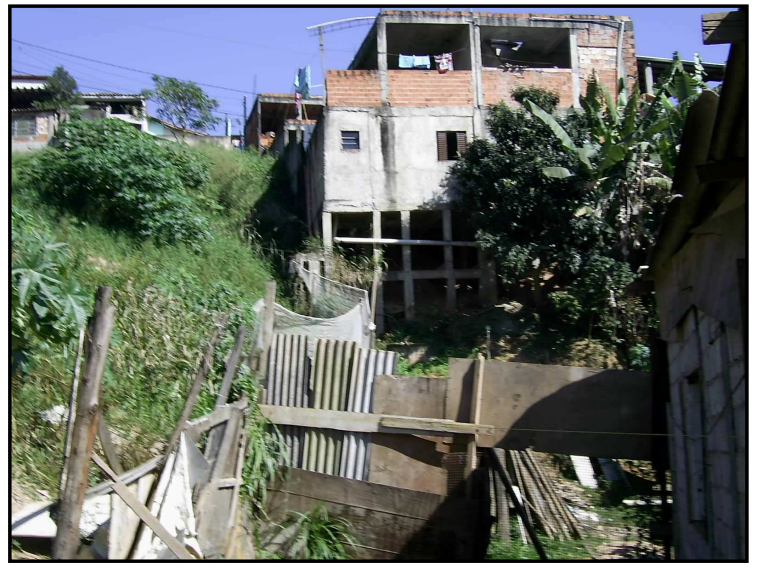

Foto 09 - Vila Indiana:Ocupação desordenada.

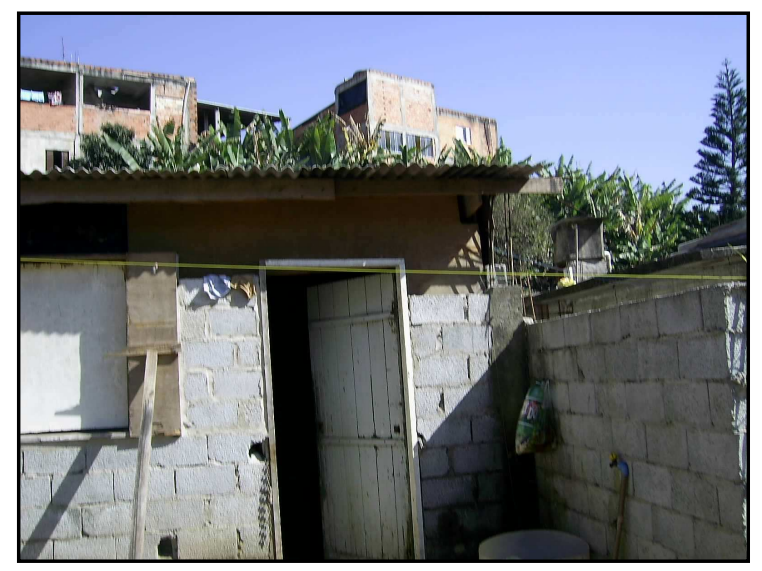

Foto 10 - Vila Indiana:Construção de baixo padrão. 
112

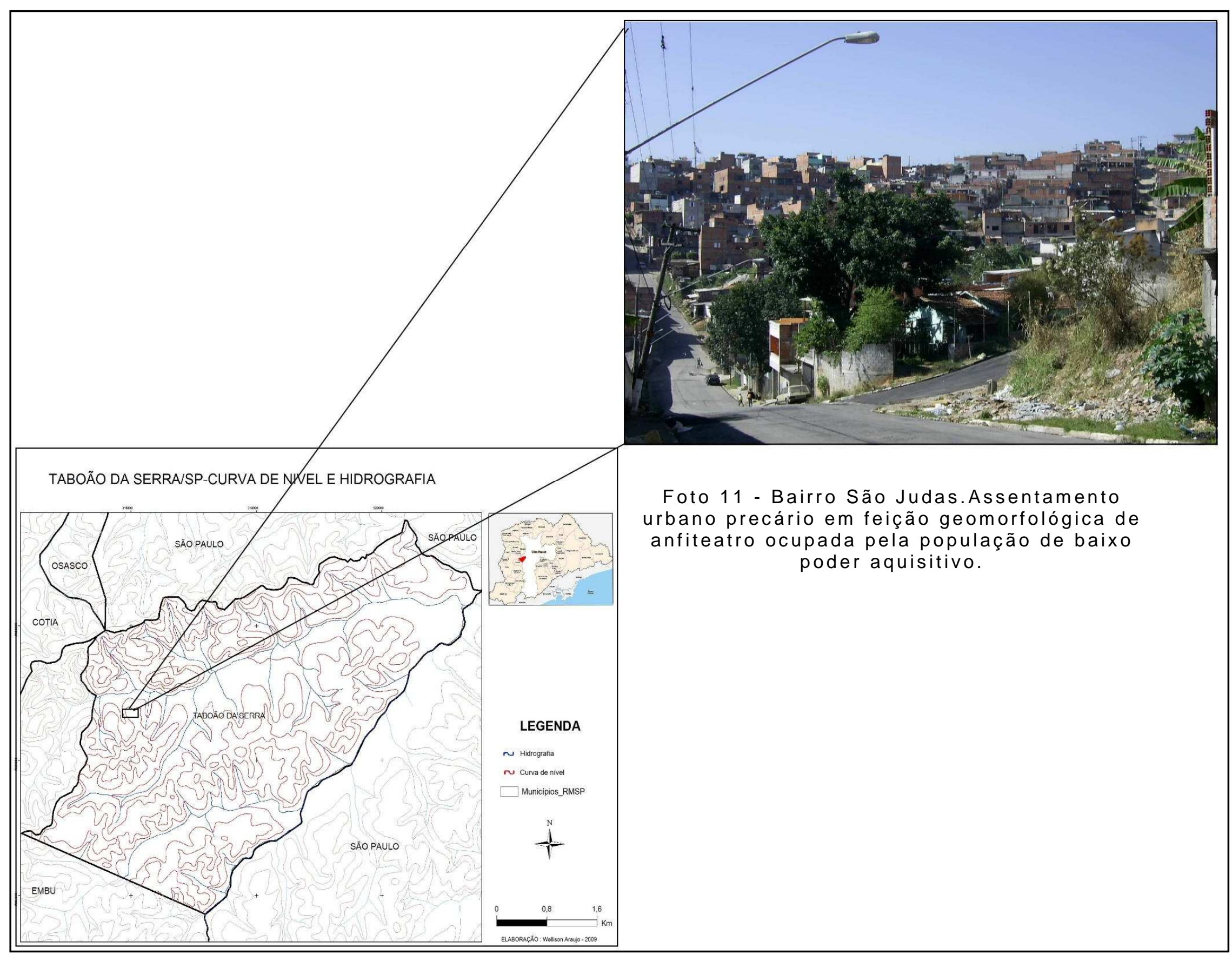


Fig. 21 TABOÃO DA SERRA-SP- HIPSOMETRIA

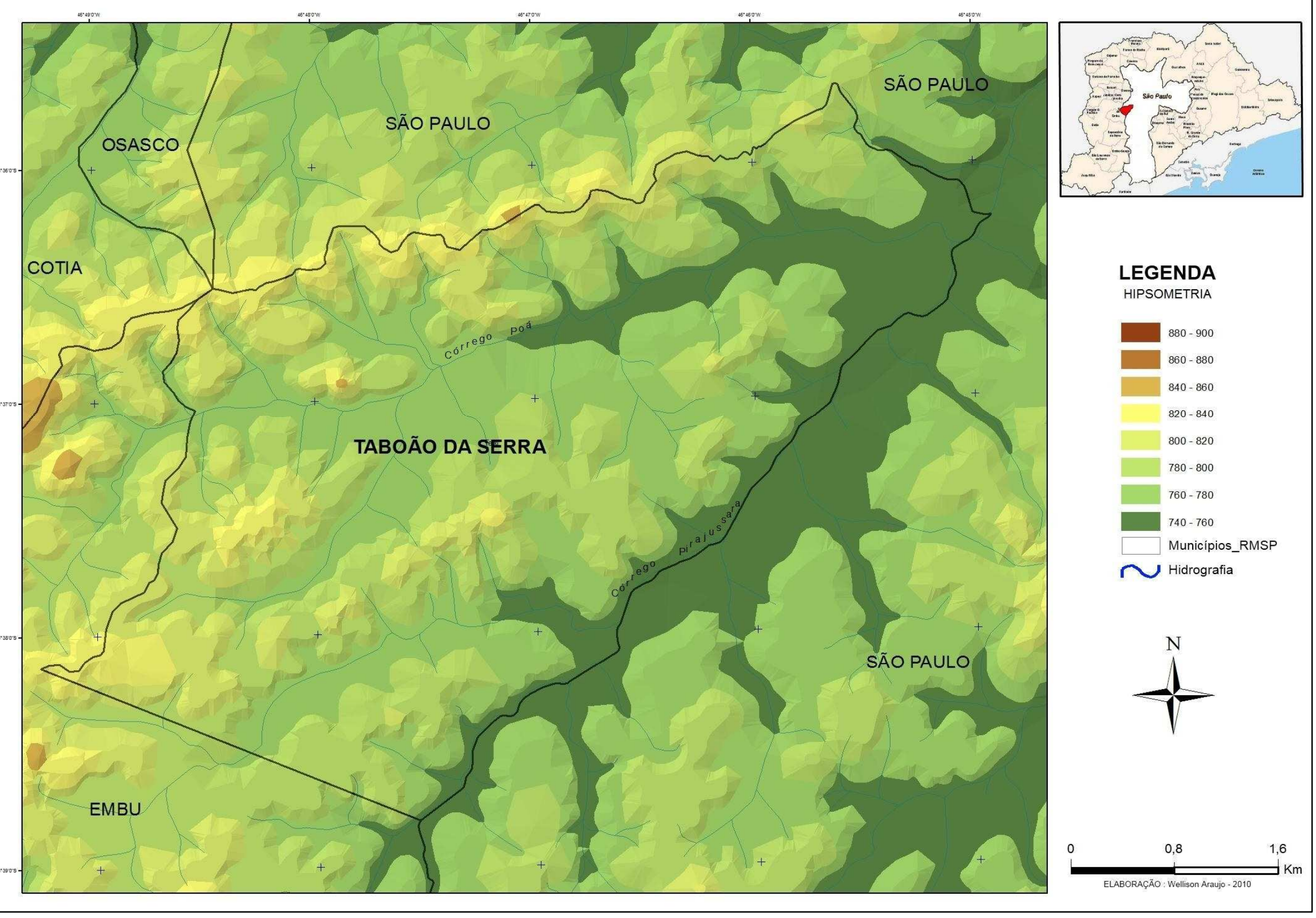




\subsection{Carta Clinográfica}

A carta clinográfica ou de declividades (Fig.22) apresenta as vertentes na área do município. Em termos da espacialização das mesmas verifica-se a predominância da classe de declividade situada entre 0 e $1,72 \%$, o que representa as áreas de várzeas que são constantemente utilizadas pelos córregos nas vazantes.

Estas áreas foram ocupadas, principalmente pela população de baixa renda, os córregos nesta faixa de declividade estão praticamente entubados, verificando-se in locus uma tendência a priorizar o construído ante o natural.

No setor NE do município, onde há o encontro dos córregos Poá e Pirajussara, a problemática ambiental se torna mais evidente, pois as baixas declividades contribuem para a potencialização do aumento do fluxo fluvial quando de grandes tempestades, aliado ao lixo jogado nos córregos, provocando a subida rápida da água mesmo com a presença do piscinão.

Por outro lado, nas declividades entre 11,31 a 16,70 e ate mais, encontram-se construções de 2 e até 3 pavimentos (região SW do município- bairros São Judas, Parque Pirajussara, Saint Moritz etc.), evidenciando a ocupação de terrenos inapropriados, tanto pela sua forma geométrica quanto pela sua inclinação.

Nestas formas de colinas com alta declividade, os terrenos que antes eram protegidos por uma vegetação original, que propiciava a manutenção dos processos morfogenéticos, sofrem atualmente um processo de compactação, pela retirada da vegetação, cobertura por cimentação contribuindo para modificar também o fluxo pluvial.

As menores declividades ocorrem predominantemente nas baixas vertentes e fundos de vales (onde se localizam as áreas de várzeas), mas em menor proporção nos topos (que são divisores de águas ou de bacias). 
Os topos planos são os restos de um nível morfológico a partir do qual houve o entalhamento das formas atuais pela rede de drenagem, que produziu as formas de vertentes e seus depósitos.

Observa-se que as menores declividades encontram-se obviamente circunscritas à bacia hidrográfica do córrego Pirajussara e do córrego Poá, como também ao longo da Rodovia Régis Bittencourt no sentido SW/NE.

Embora as áreas demarcadas em vermelho e laranja sejam em termos percentuais menores que as áreas com menores declividades, nota-se, em comparação com a carta de Uso da Terra, que os bairros mais populosos encontram-se na faixa esquerda ao longo da Rodovia, o que denota a ocupação de terrenos com declividades acima de 16 graus.

A ocupação dessas áreas com maiores declives, impõe ao poder público maiores responsabilidades quando se realiza obras de urbanização, pavimentação e captação de águas pluviais, assim como da implantação de rede adequada de esgotamento sanitário. 


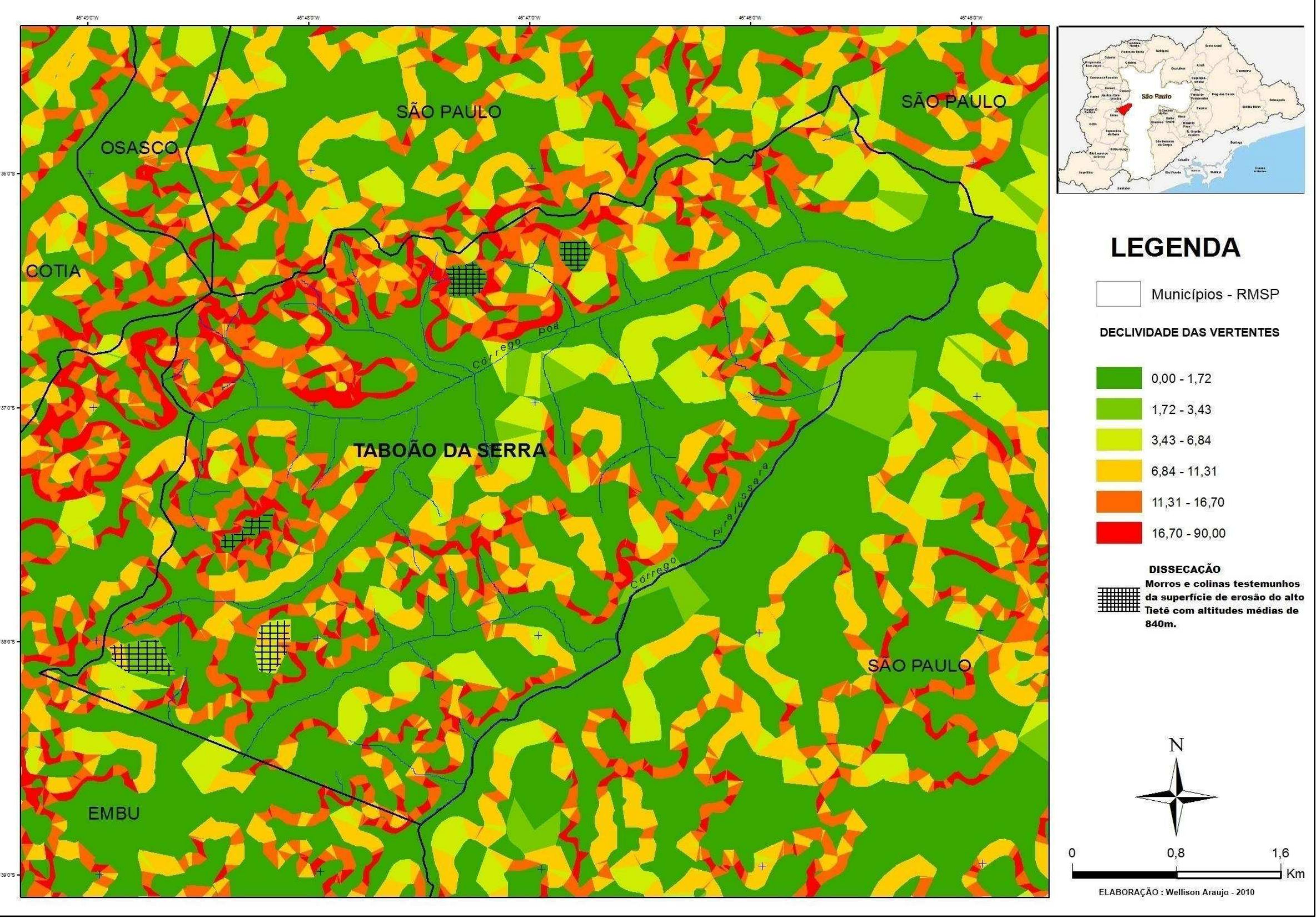




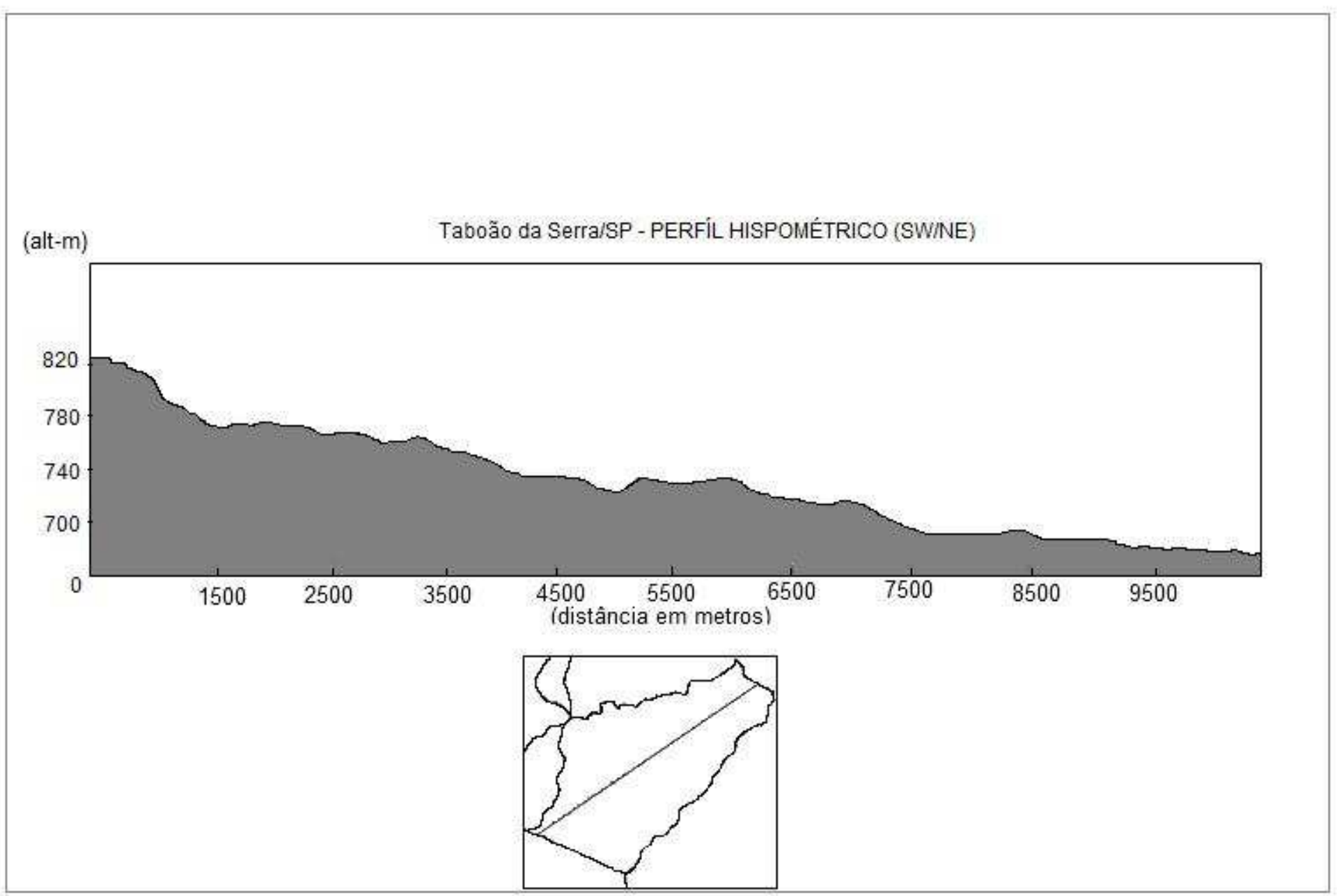

Fig.23: Perfil hipsométrico de Taboão da Serra no sentido SW-NE. 


\section{Fig. 24 TABOÃO DA SERRA/SP-PERFÍS TOPOGRÁFICOS TRANSVERSAIS}
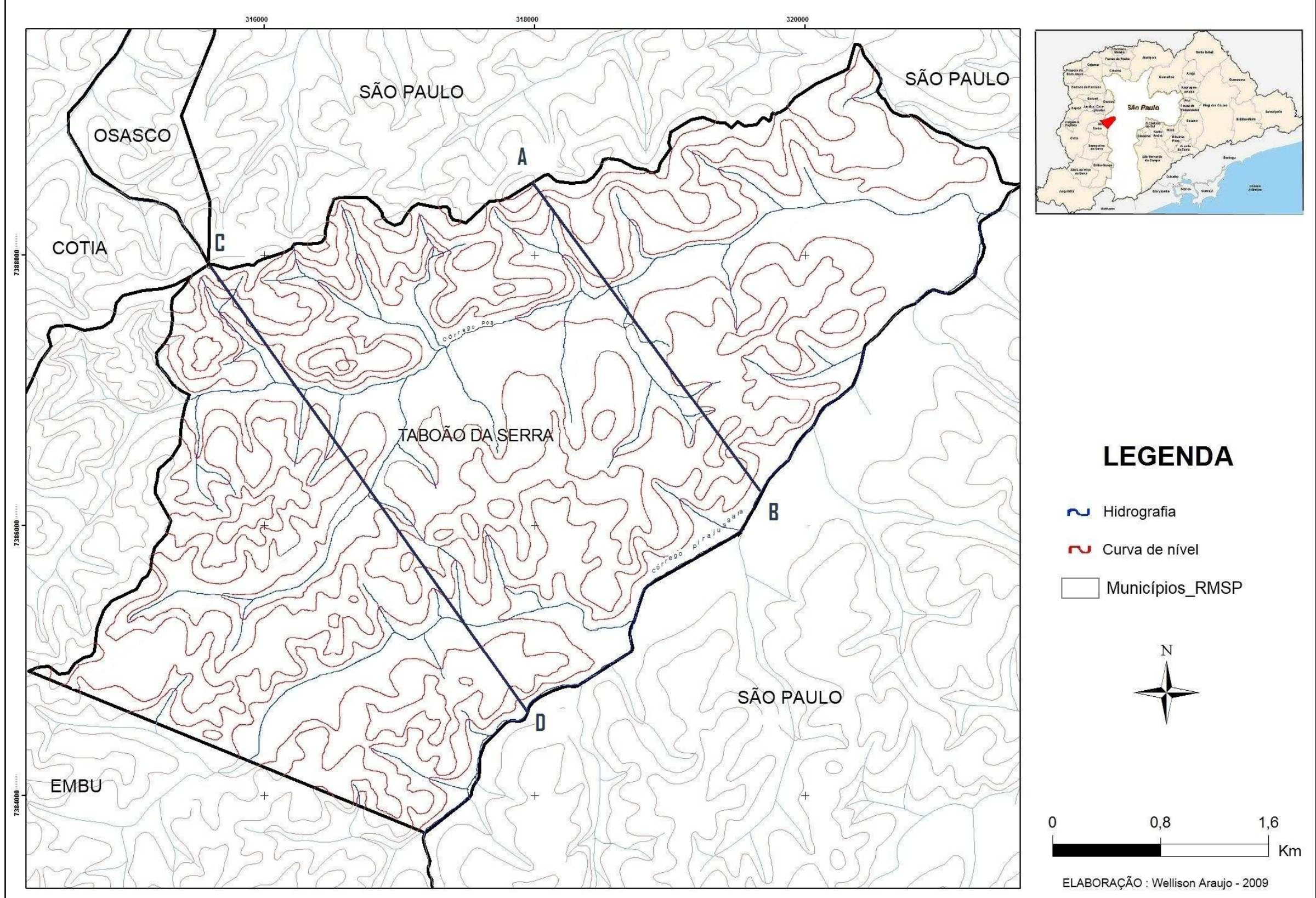


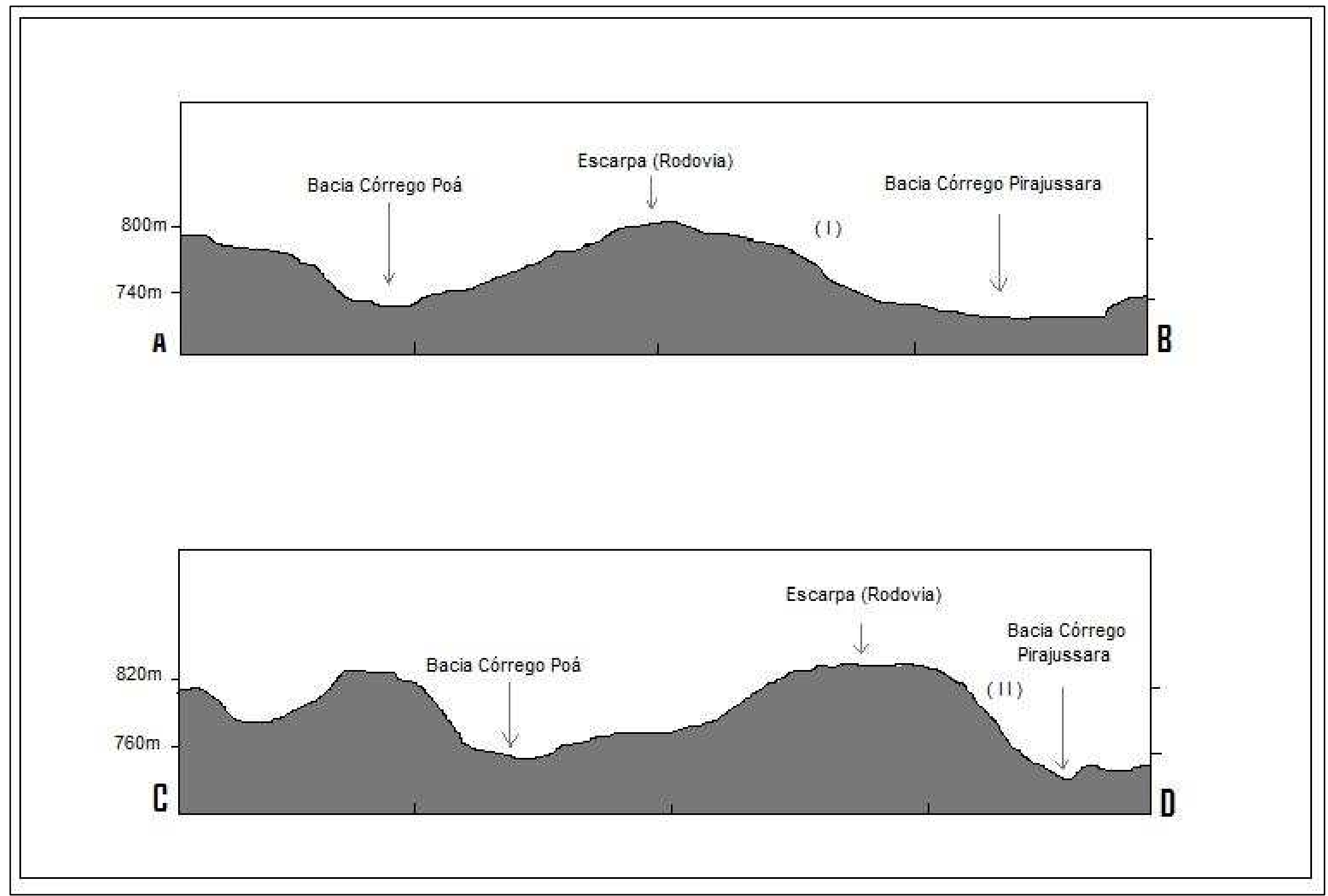

Fig.25: Perfís topográficos transversais ao Espigão Central de Taboão da Serra: Assimetria do relevo. 
Os perfis topográficos transversais (Fig.25) são importantes por demonstrar visualmente as características do relevo do município.

O recorte A/B, realizado na altura do Km 271 da Rodovia Régis Bittencourt (proximidades do Shopping Taboão), revela declividades mais suaves se comparadas com o recorte C/D. O entalhamento realizado pelo córrego Poá contribuiu para aprofundar o leito e também construir uma vertente mais abrupta no sentido SW/NE à direita da carta no sentido capital/interior. Esta vertente recebeu influências externas pela atividade tectônica realizada pelo soerguimento dessa região direcionadas para a bacia do Rio Pinheiros.

Esta rampa, que na verdade ocupa todo o território de Taboão da Serra, está subdividida em 3 planos estruturais principais:

$\checkmark \quad$ O interflúvio do córrego Poá, assentado sobre um tipo de rocha diferenciado da maior parte do substrato do município, caracterizado por uma faixa de domínio no sentido SW/NE, vide carta Geológica (Fig.24), aproveitado pelo córrego para realizar seu escoamento através dos planos de fratura. Tal domínio rochoso representativo do magmatismo do domínio Embu tem nos granitóides as rochas mais comuns.

Nesta faixa concentram-se as áreas mais elevadas e íngremes do território municipal, onde as curvas de nível se adensam. Tal característica representa uma dificuldade para a ocupação urbana, fato este que é corroborado pela maior concentração de cobertura vegetal e pela menor concentração de construções em comparação com outras áreas do território;

O espigão representado pelo topo da colina, onde está assentada a zona de contato entre o substrato rochoso dos granitóides e das rochas xistosas intercaladas com 
muscovitas, biotitas e quartzos xistosos. Com direcionamento SW/NE, esta feição foi aproveitada como zona de orientação para a construção da Rodovia Régis Bittencourt, que está localizada nos topos do espigão. Esta escarpa está delimitada por 2 interflúvios (Poá e Pirajussara) e é onde encontram-se localizadas a maioria das indústrias da região;

O interflúvio do córrego Pirajussara, também assentado sobre rochas xistosas, tem como característica as altas declividades do terreno. Esta área está em contato com a divisa do município de São Paulo, e demograficamente é a área mais adensada em termos de ocupação. Representadas em ambos os perfis A/B e C/D pelos algarismos (I) ao norte e (II) ao sul, estas duas áreas apresentam eqüidistâncias das curvas de níveis menores à medida que se afastam da várzea do Pirajussara. Essa proximidade da curvas revelam declividades maiores, representados por vertentes abruptas mas, densamente povoadas. Nestes setores localizam-se a maioria dos eventos de escorregamentos e de desmoronamentos de encostas nos meses de verão, época em que as chuvas são mais intensas. Bairros como Parque Pirajussara, Parque Pinheiros, Saint Moritz, São Judas, Jardim Record concentram a maior parte desses eventos morfogenéticos.

A dinâmica do relevo nestes locais foi intensamente modificada pelo especulador imobiliário como também pela ocupação intensiva e indiscriminada das encostas pela população de baixa renda. Nas áreas de várzeas, onde as curvas de níveis são mais espaçadas, ocorre também a ocupação humana, representada por construções que invadem a área de inundação do córrego, tal processo, aliado ao lançamento de lixo e esgotos no córrego contribuiu 
para maximizar os episódios de inundações, fato este que é comum nas áreas circunvizinhas do córrego Pirajussara.

\subsection{Carta Geológica}

A carta geológica para Taboão da Serra (Fig.27) foi elaborada tendo como base o Mapa Geológico do Estado de São Paulo na escala de 1:750.000, elaborada pelo CPRM (Companhia dePesquisas de Recursos Minerais) e Serviço Geológico do Brasil, que foi publicado em 2006. No domínio geológico, representado na carta pela cor laranja, está a faixa que abrange a unidade NP3ey 1 que se estende no sentido SW/NE. A unidade NPexm está representada pela cor cinza e, domina mais de $60 \%$ da área do município. Segue na tabela seguinte a descrição de cada unidade. 


\section{Tab. 08 - Taboão da Serra - Unidades Litoestratigráficas}

\begin{tabular}{|c|c|}
\hline $\begin{array}{c}\text { NP3ey1 } \\
\text { Granitóides quimicamente } \\
\text { indiferenciados, pré a sincolisionais do } \\
\text { Terreno Embu }\end{array}$ & 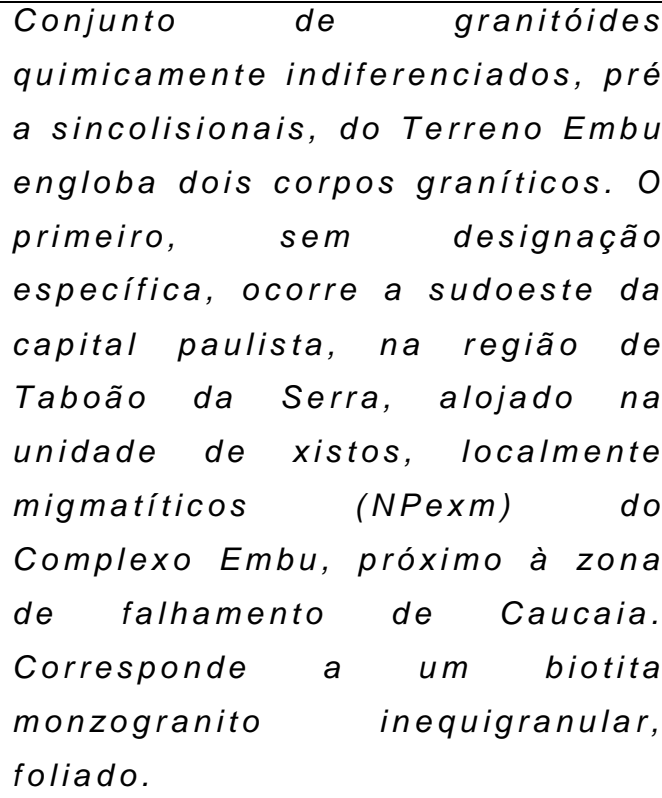 \\
\hline $\begin{array}{c}\text { Embu, Complexo - unidade de xistos } \\
\text { localmente migmatíticos }\end{array}$ & 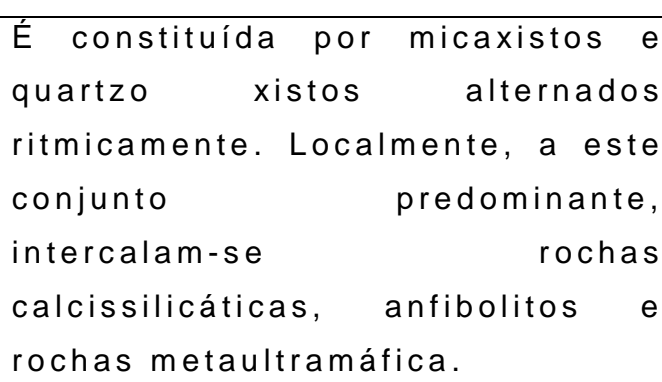 \\
\hline
\end{tabular}


O embasamento geológico da área que abrange o município, tem como característica principal a presença de uma linha de falha transcorrente dextral ${ }^{15}$ no setor norte, mais precisamente no sentido Sudoeste/Nordeste. Esta zona de falhamento/fratura, se apresenta combinada com as maiores altitudes na carta hispométrica.

In situ pode-se distinguir as seguintes características que são representativas pela presença dessa linha de falha:

- Ao norte no território do município, encontra-se as áreas mais elevadas, caracterizado por altitudes que chegam a aproximadamente $900 \mathrm{~m}$, essa faixa de montanhas segue no sentido noroeste/norte. Distinguese também as declividades no sentido noroeste/sudeste que percorrem toda a faixa laranja do domínio NP3ey1, essa inclinação exerce influência no direcionamento dos canais, principalmente aqueles que são tributários do Córrego Poá que corta os bairros de (Monte Alegre em Embu), (São Judas, Intercap, Maria Rosa em Taboão da Serra);

- O contato da falha nos dois domínios NP3ey1 e NPexm, em termos geomorfológicos, compõem na superfície a zona de fratura em que o córrego construiu seu canal, no sentido sudoeste/nordeste, sendo este córrego um dos principais tributários do Córrego Pirajussara, fazendo seu encontro na altura do bairro Jd. Maria Rosa;

- No setor sul do município, destaca-se o complexo litoestratigráfico NPexm, que ocupa a maior parte do

${ }^{15}$ Lineamento perceptível na topografia indicativa da interseção entre o plano de falha e a superfície do terreno. Deformação das rochas em zonas tensionadas que sofrem pressão dirigida, levando a ruptura e deformações texturais e estruturais com deslocamentos paralelizados ao plano principal de ruptura próximo. (Visual Glossary do USGS). 
território do município. Esta faixa inicia-se na zona de falhamento do contato deste domínio com o domínio litoestratigráfico NP3ey1. No setor sul, onde limita-se com o município de São Paulo (Bairro do Campo Limpo), encontra-se encaixado o Córrego Pirajussara), o maior tributário do Rio Pinheiros. Este domínio, é caracterizado por apresentar nas proximidades do Córrego ou seja, nas áreas de várzea as menores altitudes do município (aproximadamente $750 \mathrm{~m}$ ), o Córrego Pirajussara portanto, encontra-se encaixado nos domínios do Complexo litoestratigráfico Embu: contato entre a formação NPepg (Unidade paragnáissica muscovita-granada-silimanita-biotita-gnaisse migmatítico-biotita gnaisse tonalítico a granodioríticoxisto granaissoide e biotita gnaisse quartzoso) e NP3ey 1 (Granitóide quimicamente indiferenciados - Pinheirinho $\mathrm{Pi}$ ).

Geologicamente podemos afirmar que a área de estudo se traduz por ser um pacote rochoso, que foi profundamente afetado por eventos tectônicos antigos que criaram muitos planos de fraqueza aproveitados pela água para percolar e escavar.

Profundamente decomposto, possuía vertentes de média a alta declividades com estrutura pedológicas e coberturas coluviais em equilíbrio dinâmico propiciado pela cobertura vegetal. Este sistema natural, por vezes pode sofrer desequilíbrio pela ação antrópica indiscriminada, principalmente sobre a cobertura vegetal.

A carta geológica correlacionada com as cartas geomorfológica e hipsométrica, nos ajuda a compreender a dinâmica superficial tanto do direcionamento dos canais como também do fluxo das águas pluviais. 
Por outro lado, as formas de ocupação do solo, principalmente das áreas de várzeas e das encostas mais íngremes, provocam desorganização desses fluxos que resultam em problemas ambientais demandando gastos do poder público para minimizar a problemática.

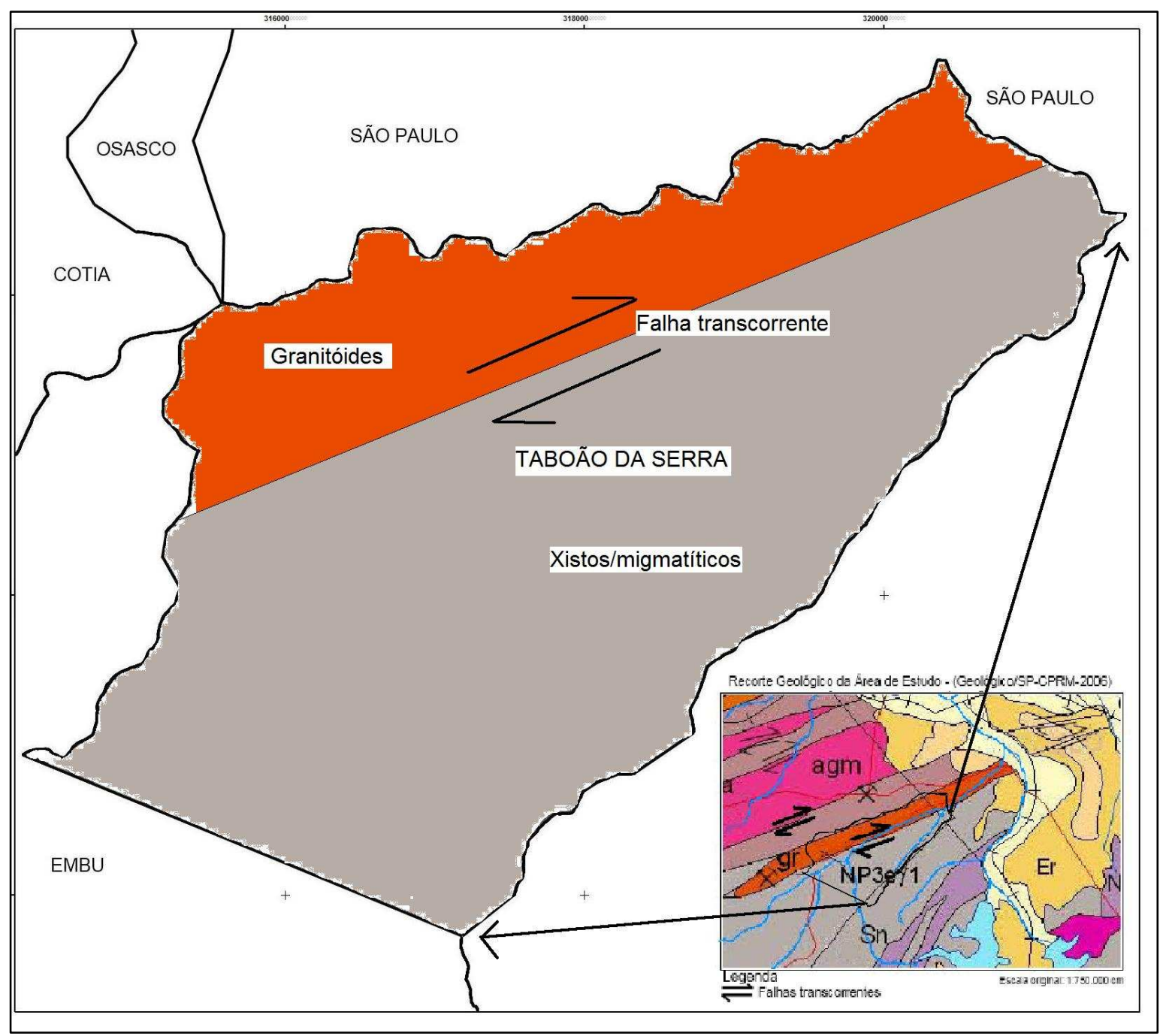

Fig. 26- Falhas transcorrentes locais

Fonte: Carta Geológica 2006 - CPRM. 
Há a presença de falhamentos transcorrentes, originados de movimentos horizontais, essas falhas são aproveitadas como linhas onde os córregos Poá e Pirajussara abrem caminho para a jusante contribuírem com o Rio Pinheiros. 
Tabela 09: Classificação das rochas segundo a vulnerabilidade à denudação

\begin{tabular}{|c|c|c|}
\hline $\begin{array}{l}\text { TIPOS } \\
\text { ROCHAS }\end{array}$ & LITOLOGIAS & $\begin{array}{c}\text { GRAU DE } \\
\text { VULNERABILIDADE }\end{array}$ \\
\hline Metamórficas & Quartzitos/Metaquartzitos & 1,0 \\
\hline Ígneas & Riolito,Granito, Dacito & 1,1 \\
\hline Ígneas intrusivas & $\begin{array}{c}\text { Granodiorito, Quartzo, Quartzo diorito, } \\
\text { Granulitos }\end{array}$ & 1,2 \\
\hline Metamórficas & Migmatitos, Gnaisses & 1,3 \\
\hline Ígneas intrusivas & Fonólito, Nefelina, Sienito, Traquito & 1,4 \\
\hline Ígneas & Andesito, Diorito, Basalto & 1,5 \\
\hline Ígneas intrusivas & Anortosito,Gabro,Periodito & 1,6 \\
\hline Metamórficas & $\begin{array}{c}\text { Milonitos, Quartzo } \\
\text { Muscovita,Biotita, Clorita, Xisto }\end{array}$ & 1,7 \\
\hline $\begin{array}{l}\text { Ígneas } \\
\text { metamórficas }\end{array}$ & $\begin{array}{c}\text { Piroxenito, Anfibolito, Kymberliyto } \\
\text { Dunito }\end{array}$ & 1,8 \\
\hline Ígneas & Hornblenda,Tremolita, Actinolita Xisto & 1,9 \\
\hline Metamórficas & Etaurolita Xisto, Xistos Granatíferos & 2,0 \\
\hline Metamórficas & Filito, Metassiltito & 2,1 \\
\hline Metamórficas & Ardósia, Metargilito & 2,2 \\
\hline Metamórficas & Mármores & 2,3 \\
\hline Sedimentares & Arenitos Quartzosos ou ortoquartzitos & 2,4 \\
\hline Sedimentares & Conglomerados, Subgrauvacas & 2,5 \\
\hline Sedimentares & Grauvacas, Arcózios & 2,6 \\
\hline Sedimentares & Siltitos, Argilitos & 2,7 \\
\hline Sedimentares & Folhelhos & 2,8 \\
\hline
\end{tabular}




\begin{tabular}{|l|c|c|}
\hline Sedimentares & Calcários,Dolomitos,Margas, Evaporitos & 2,9 \\
\hline Sedimentares & $\begin{array}{c}\text { Sedimentos inconsolidados:aluviões, } \\
\text { colúvios }\end{array}$ & 3,0 \\
\hline
\end{tabular}

Fonte: Crepani et al (2001)

O grau de vulnerabilidade das rochas à denudação, é o resultado do intemperismo aliado à erosão.

$\mathrm{Na}$ carta geológica da área de estudo, de acordo com a classificação de Crepani et al (2001), podemos concluir que as rochas mais comuns apresentam grau alto de resistência à denudação (Granodiorito, Gnaisses, Muscovita,Biotita, Xisto).

A excessão são os xistos granatíferos que apresentam grau 2). Podemos concluir que as rochas ai encontradas apresentam alto grau de coesão nas suas estruturas sendo na sua maioria rochas do tipo metamórficas. 
Fiq.27 TABOÃO DA SERRA/SP - EMBASAMENTO GEOLÓGICO

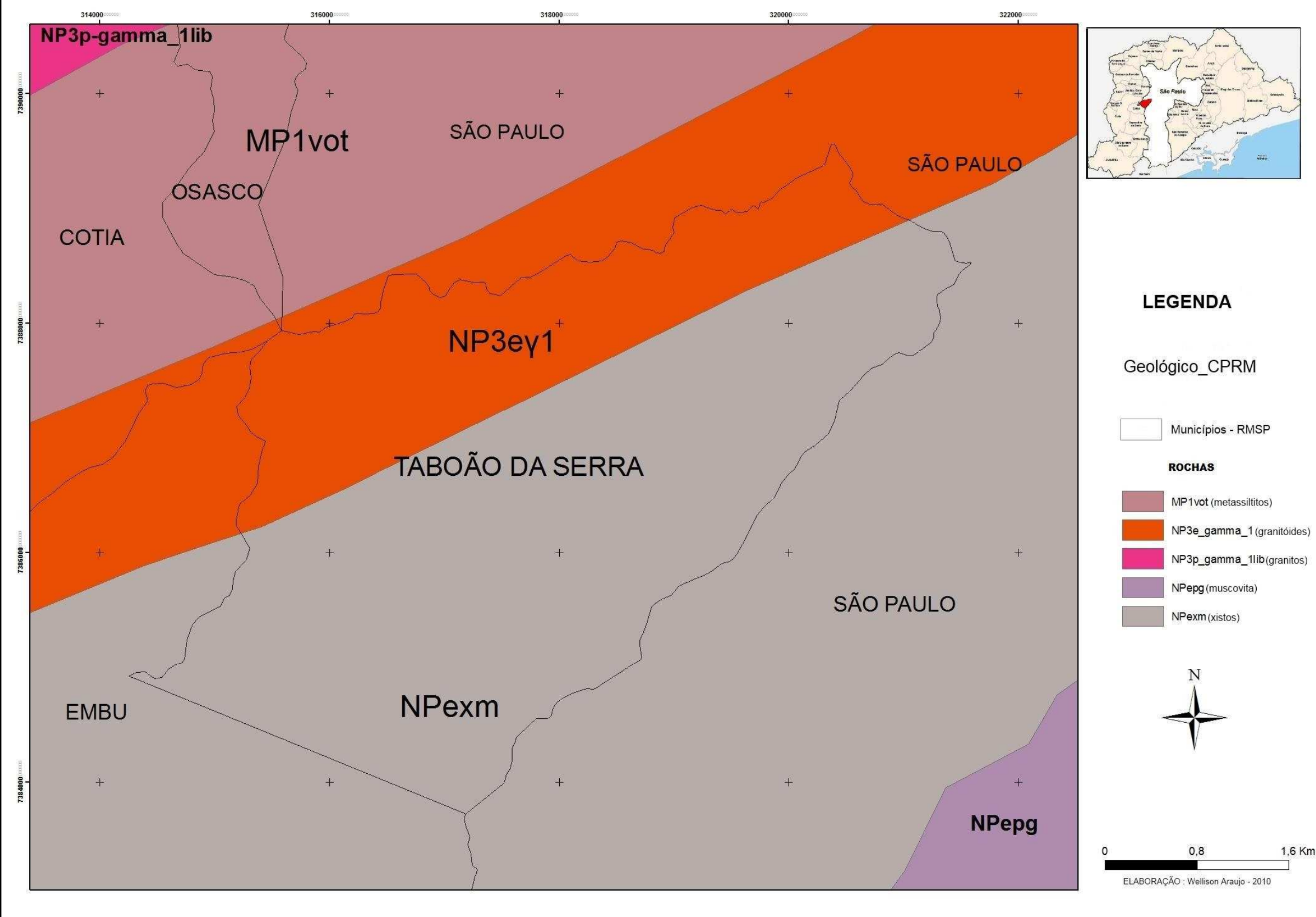




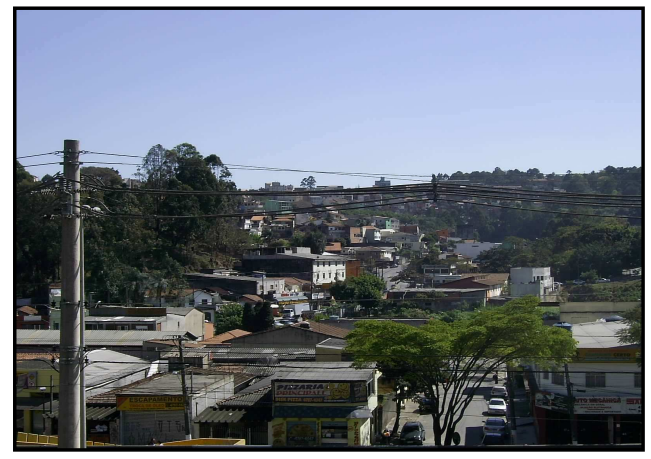

Foto 12 Feição de anfiteatro ocupada: Jardim Intercap.

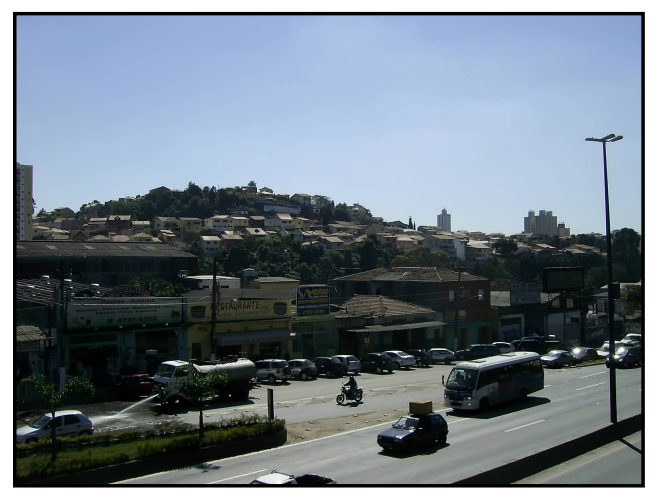

Foto 14: Área de morrarias, ocupadas por habitações de alto padrão.

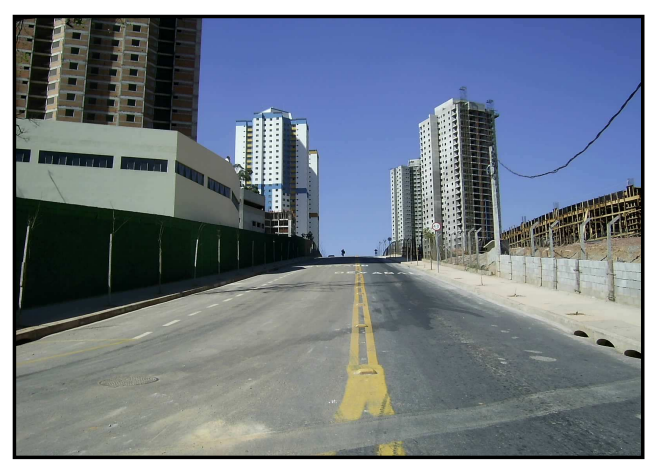

Foto 16: Cooperativa Vida Nova: Exemplo de ação privada sobre as formas: pavimentação de morros. com condomínios fechados.



Foto 13: Sequência da feição de anfiteatro ocupada: Jardim Intercap.

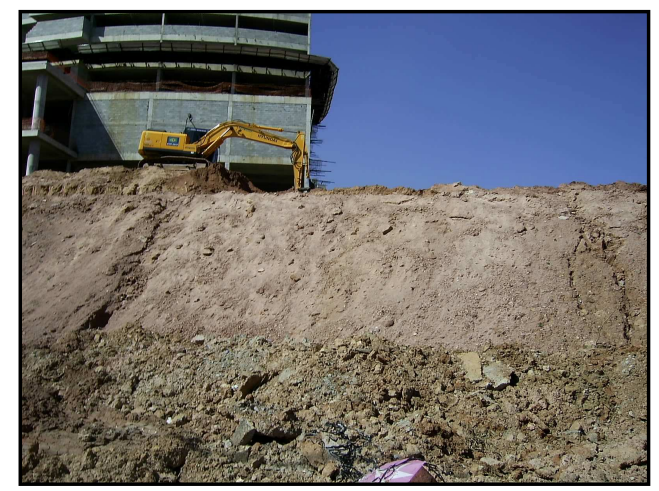

Foto 15: Área de morraria sendo modificada artificilamente pela ação privada com aval da prefeitura.

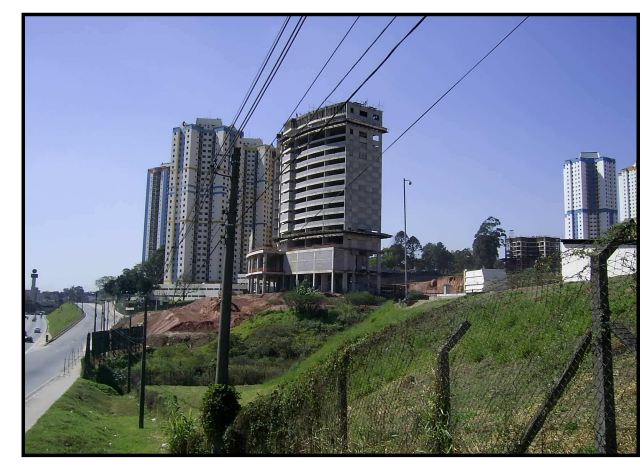

Foto 17: Visão lateral sul do Conj. Cooperativa Vida Nova. No vale entulhamento de córrego. 


\subsection{Cobertura Vegetal e os Processos Morfodinâmicos}

A utilização do tema cobertura vegetal como elemento natural relevante de análise na geografia, teve como fator dinamizador, o início da utilização do geoprocessamento para a interpretação do uso da terra, sendo assim, utiliza-se de análises de imagens orbitais para se verificar o avanço do meio urbano sobre a cobertura vegetal.

No entanto, para a caracterização da cobertura vegetal da região de estudo, fizemos a interpretação a partir de pesquisas mais amplas realizadas para o Estado de São Paulo e região metropolitana, apoiadas em vôos fotogramétricos tendo como resultado um mosaico de ORTOFOTOS na escala 1:10.000, para dois momentos do município uma cobertura para o Uso da Terra em 1962, e outra cobertura para o Uso da Terra em 2007.

$\mathrm{Na}$ região de Taboão da Serra, particularmente nos dois períodos, nota-se que a distribuição da cobertura vegetal está ficando cada vez mais rarefeita, sejam elas nos bairros caracterizados como sendo de ocupação de alto padrão, sejam elas nos bairros ocupadas pelas populações de baixo poder aquisitivo.

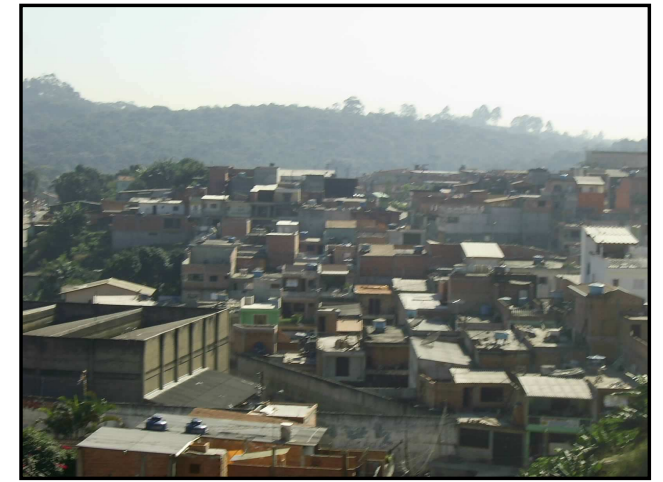

Foto 18: Vila Indiana: Avanço de habitações de baixo padrão sobre área de vegetação remanescente.

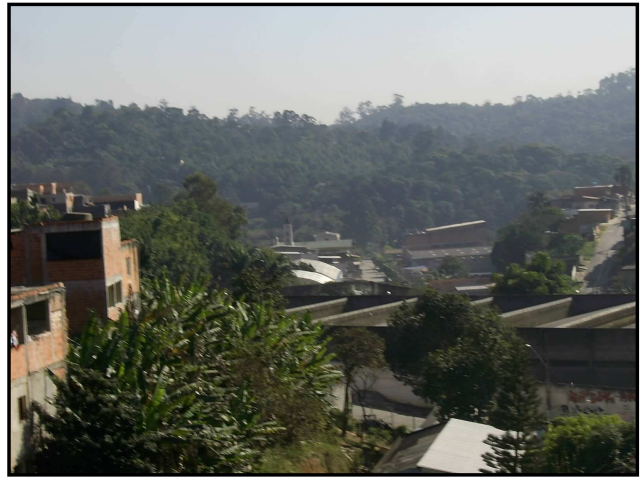

Foto 19: Vila Indiana: Ao fundoVegetação remanescente sendo substituída por indústrias e habitações de baixo padrão. 
As intervenções de ordem antropogênicas, que interferem nas condições naturais das formas, observados na área de estudo, ocorrem sobre uma superfície representadas pela ocorrência de rochas intemperizadas do embasamento cristalino, onde predominam micaxistos, granitos,, migmatitos.

Tais ocorrências sustentam formas de relevo representados pelas morrarias e colinas que, por sua vez são compostas por uma grande quantidade de materiais inconsolidados.

O maior problema reside no fato de que, na maioria das vezes, a presença da cobertura vegetal surge como um fator geoecológico que sustenta uma condição de equilíbrio. Mas tal característica está se modificando quando percebe-se que o atual estágio das intervenções antropogênicas, propicia uma alteração no comportamento dos processos morfodinâmicos.

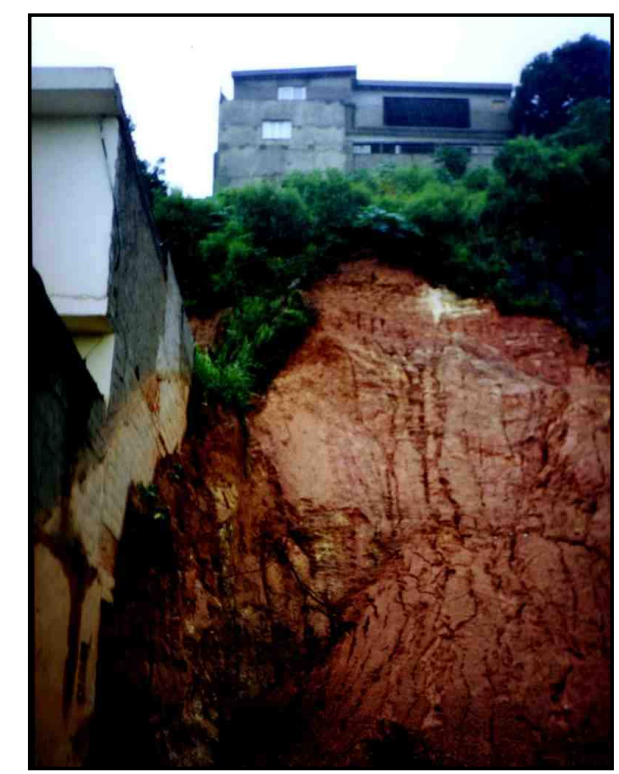

Foto 20 - Recorte de talude

A constante intervenção antropogênica (Foto 20), aliados aos efeitos do escoamento concentrado e descontínuo, provoca o aparecimento de graus de instabilidade, caracterizando um ambiente que antes apresentava um equilíbrio morfodinâmcio 
entre morfogênese/pedogênese passando a um desequilíbrio com maior peso para a morfogênese (TRICART,1977).

Segundo Ross (2006), as formas de relevo, em primeiro nível, podem ser facilitadoras ou dificultadoras dos processos de ocupação das terras, de arranjo dos espaços territoriais e da produção. Suas características são importantes para a definição dos traçados das rodovias, ferrovias, implantação de cidades, construção de aeroportos, de barragens para usinas hidrelétricas, distritos industriais, bem como para definir os tipos de atividades agropecuárias mais adequadas em função dos sistemas de produção e transporte disponíveis em cada lugar e indicar as áreas de maior interesse para a preservação e conservação dos bens ambientais de valor ecológico.

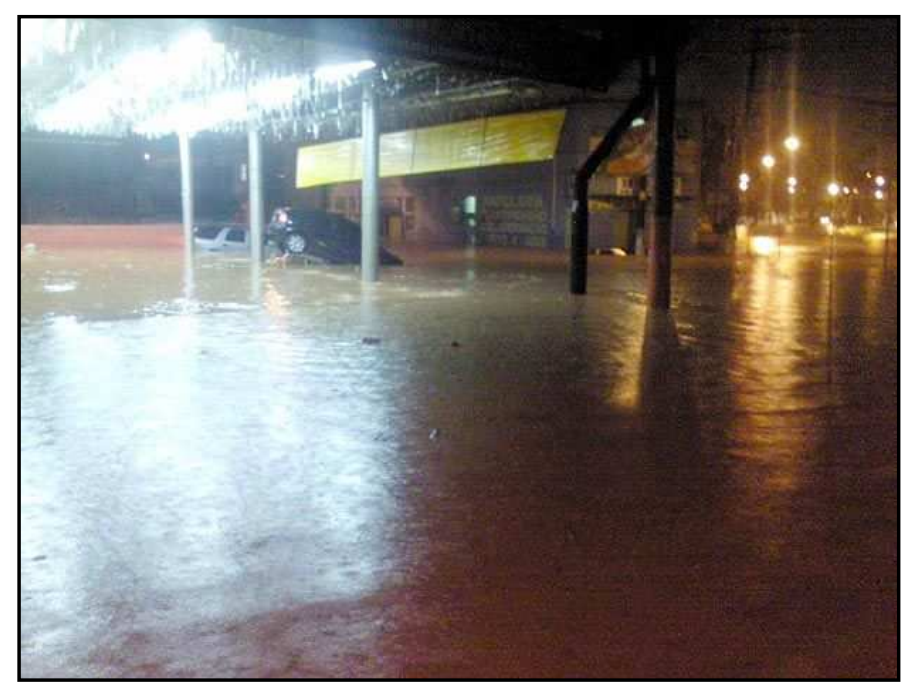

Foto 21: Episódio de inundação do córrego Pirajussara 17/12/09. Fonte: O Taboanense

Do ponto de vista geoambiental, as características naturais que restaram no município em estudo, não equivale a $10 \%$ do ambiente original, o que intensifica episódios naturais que, em contrapartida são potencializados pelo uso da terra em escala urbana resultando em eventos de inundações (Foto 21). 
Os problemas ambientais são atualmente tema recorrente em nível da pesquisa científica e tornam-se principalmente assunto do cotidiano que desafia o poder público caracterizado pela gestão do território. Esses problemas geram impactos que se relacionam com o tipo de uso do solo dado a um local.

O município de Taboão da Serra, encontra-se num território relativamente pequeno se tomarmos em comparação a área dos municípios vizinhos (cerca de $20,5 \mathrm{~km}^{2}$, representando $0,26 \%$ da área da região metropolitana, com densidade demográfica é de $9.642,68$ habitantes por $\mathrm{km}^{2}$ ), isso por conseqüência gera um impacto no uso do solo, levando em consideração que o município não apresenta área rural.

O adensamento populacional e a característica essencialmente urbana do município, gerou uma paisagem altamente modificada, assentada sobre uma geomorfologia acidentada e de solos frágeis. A insalubridade ambiental da cidade evidencia-se tanto no adensamento das edificações (Foto 18) quanto na baixa concentração de cursos d'água, que se caracterizam por pequenos córregos que foram transformados em escoadouros de dejetos industriais e residenciais.

Esta característica que é marcante nas cidades brasileiras tem como conseqüência o "stress" ambiental, que resulta por conseguinte na instalação do "desconforto ambiental" que gera, poluição sonora, visual e o aparecimento de ilhas de calor.

Nas regiões do planeta que importam o progresso tecnológico, as áreas de influência do tecnicismo gerou impactos sociais muito mais agressivos, contribuindo para um verdadeiro desequilíbrio nas relações sociais, culturais, econômicas e ambientais.Houve rápida modificação nos sistemas de produção com as novas tecnologias e essas inserções tecnológicas proporcionaram um desenvolvimento econômico que não foi 
acompanhado do desenvolvimento social e cultural e mesmo econômico para grande parte da população (ROSS, 2006).

Exemplo da problemática acima, se concretiza através das formas de construção que ocupa a maior parte do território do município:

- Construções sem proteção das paredes externas, deixando à mostra a alvenaria proporcionando infiltrações (Foto 22);

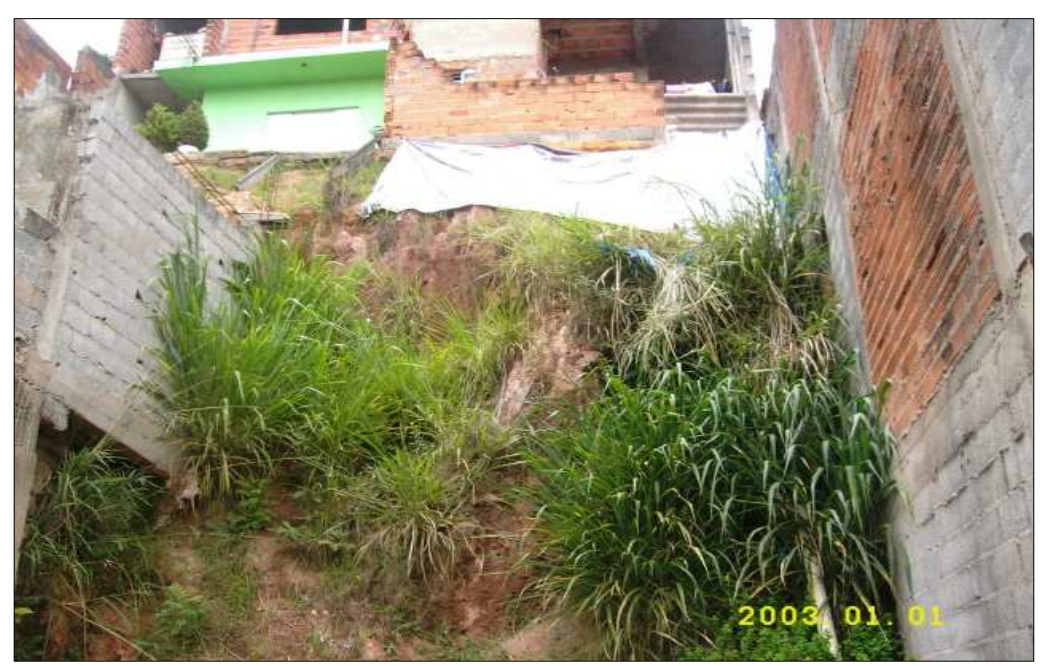

Foto 22- Vila Indiana/Taboão: Recorte de talude e construções com alvenaria à

- Moradias edificadas sobre encostas com alto grau de declividade e sobre solos instáveis e sem cobertura vegetal adequada. (Foto 23); 


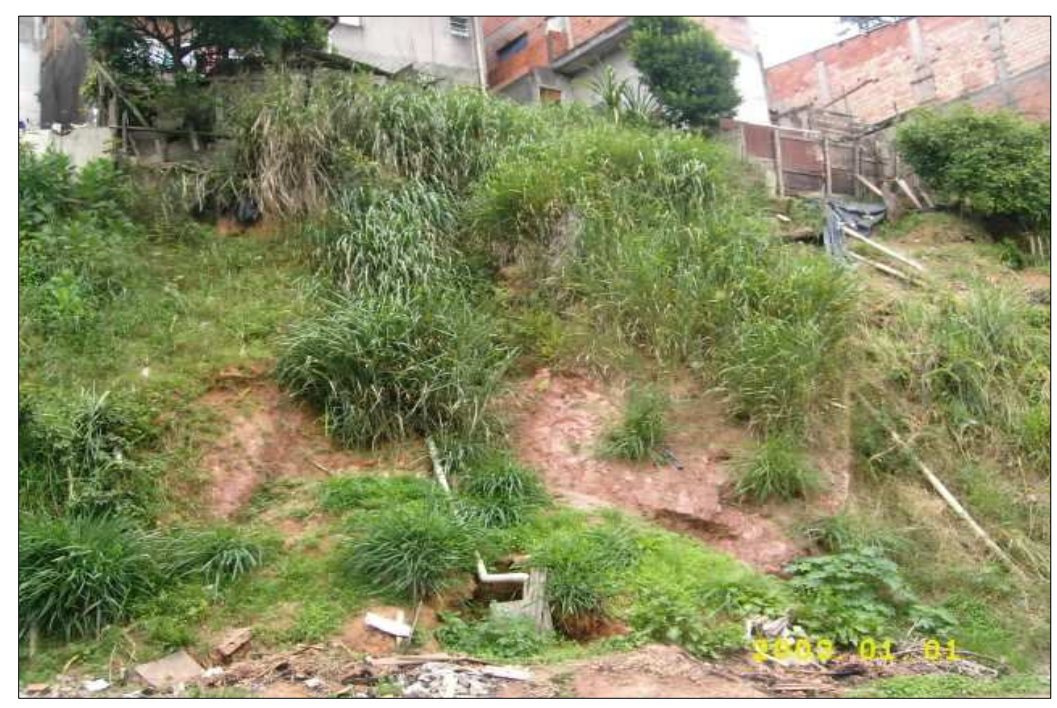

Foto 23- Vila Indiana/Taboão: Solo instável/cobertura vegetal inadequada.

- Adensamento das edificações, retirada da cobertura vegetal das encostas e construções de baixo padrão (Foto 24);

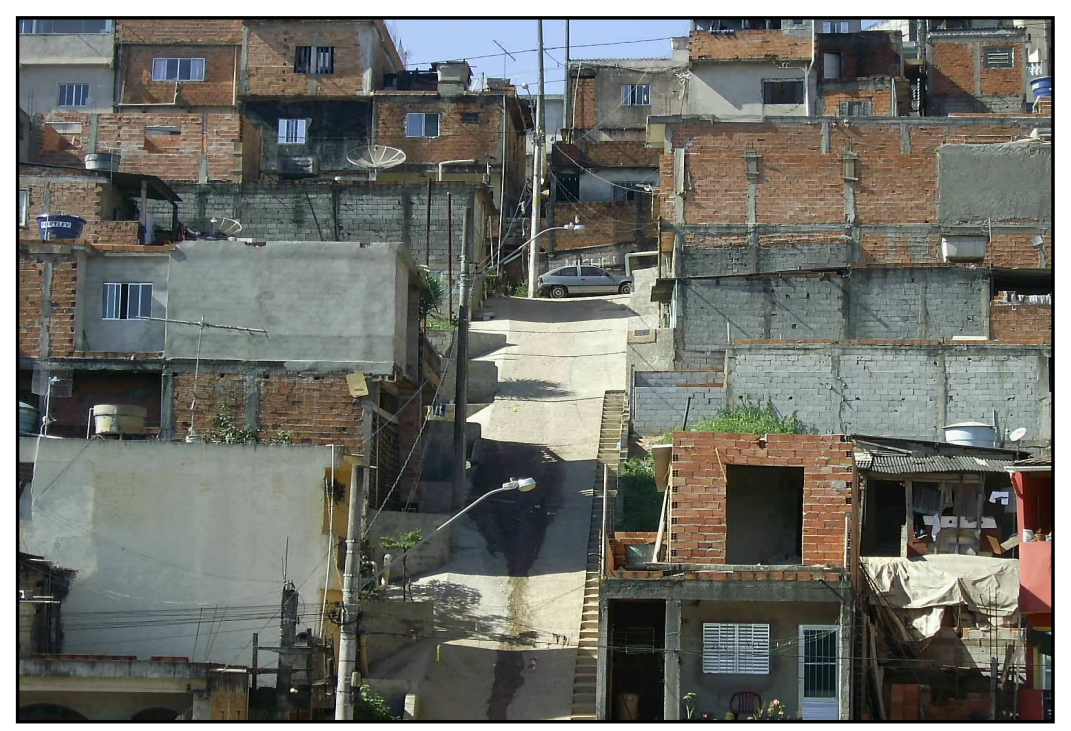

Foto 24 - Pirajussara/Taboão:Região periférica - intensa ocupação de baixo padrão.

- E por fim, construção por parte do poder público de niveladores das águas fluviais (piscinões) que não resolveu por completo o problema do transbordamento do Córrego Pirajussara o maior da região. 


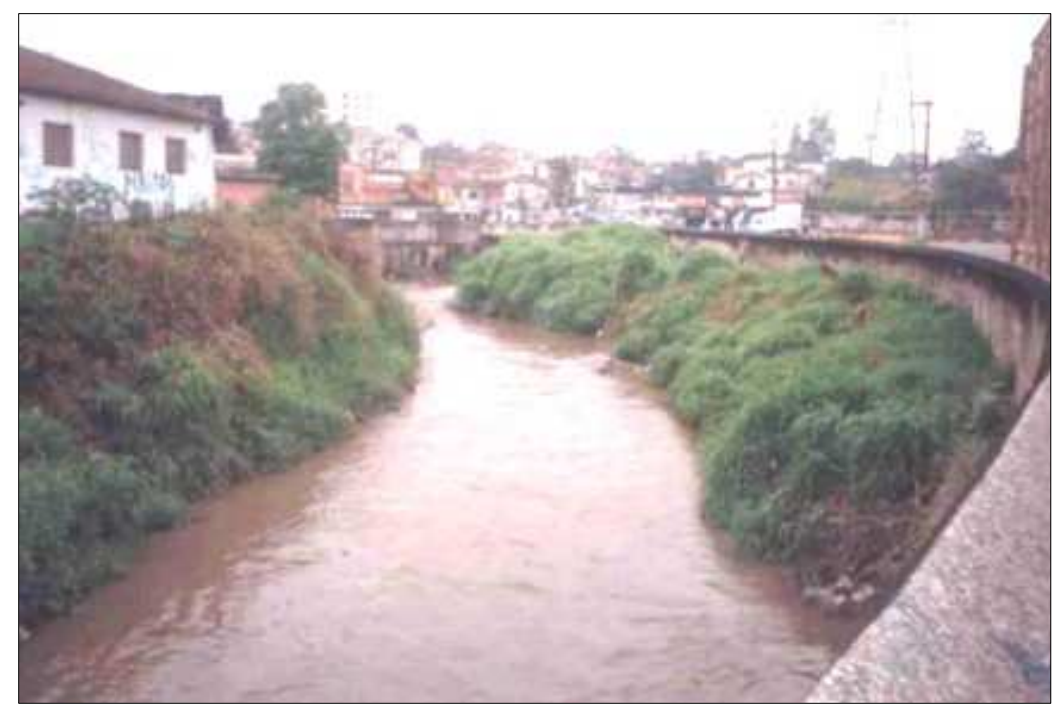

Foto 25-Ribeirão Pirajussara - Entulhamento e fechamento de canal pelo matagal.

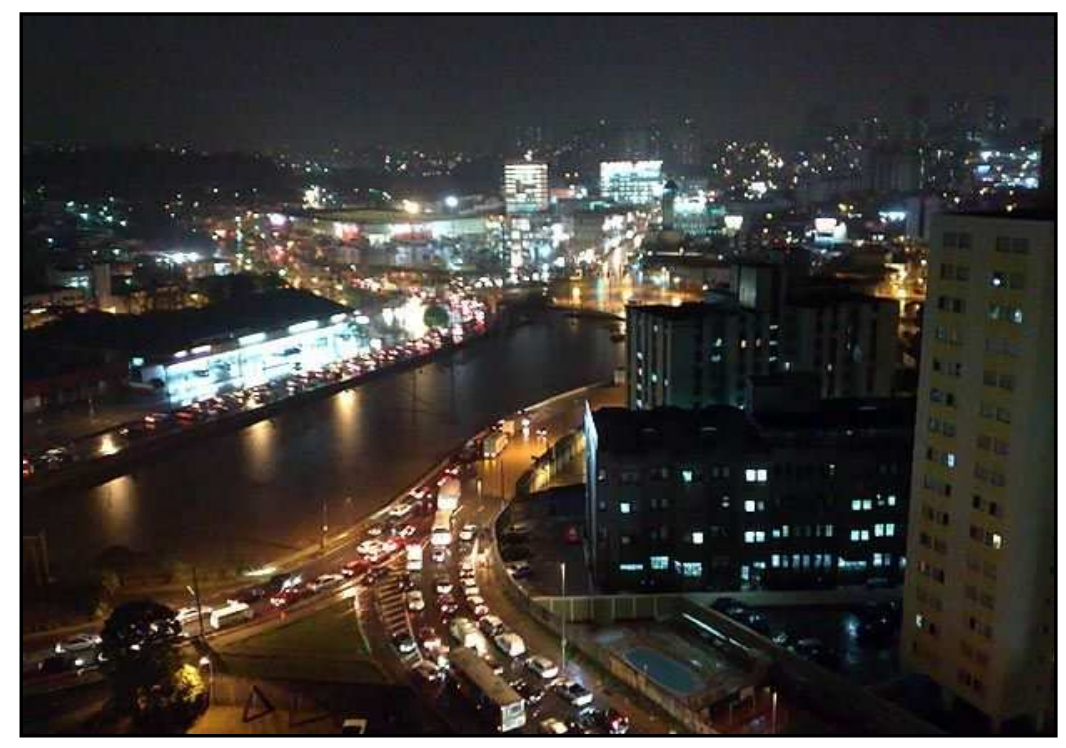

Foto 26 - Evento de transbordamento do piscinão divisa entre Butantã e Taboão da Serra. Foto do dia 27/10/09. Fonte: Vcrepórter/Taboão. 
7. EVOLUÇÃO DEMOGRÁFICA 


\subsection{Evolução Demográfica de Taboão da Serra}

O fator mais marcante para a evolução demográfica do município, foi a atração que ocorreu a partir da década de 1960 de uma população não qualificada de todas as partes do território nacional, principalmente direcionadas para a capital paulista e para a região metropolitana.

As características econômicas de Taboão da Serra são particulares pois, o município devido à sua proximidade com a capital, sempre teve um traço de cidade dormitório, onde a população ativa demandava uma migração pendular em direção a São Paulo.

A implantação de indústrias e de um núcleo comercial ainda em formação, principalmente a partir da década de 1990, vem modificando aos poucos as características econômicas do município, diminuindo mesmo que de forma incipiente a dependência econômica com relação à capital.

O setor secundário (indústrias) ainda é a principal atividade econômica do município, vindo à seguir o comércio e serviços em geral, o setor terciário ainda encontra-se em desenvolvimento, dependendo o município das atividades terciárias sediadas e desenvolvidas na capital.

A terciarização é o momento de transformação em que as características sócio-econômicos irão exercer influência no modo de reprodução sócio-espacial de uma localidade (PAILHÉ, J.1976 e PAILHÉ, J.1978;; COPPOLANI, J.1977 e 1978; JALABERT, G, 1983).

Há uma relação próxima entre, povoamento e atividade econômica, segundo Pierre George (1973) o povoamento dos países subdesenvolvidos está ligado à repartição das zonas de produção agrícola, com exceção dos núcleos urbanos cujo crescimento, por vezes muito rápido, tem por incentivo inicial o 
desenvolvimento das atividades de relação, essencialmente das relações com os países industriais.

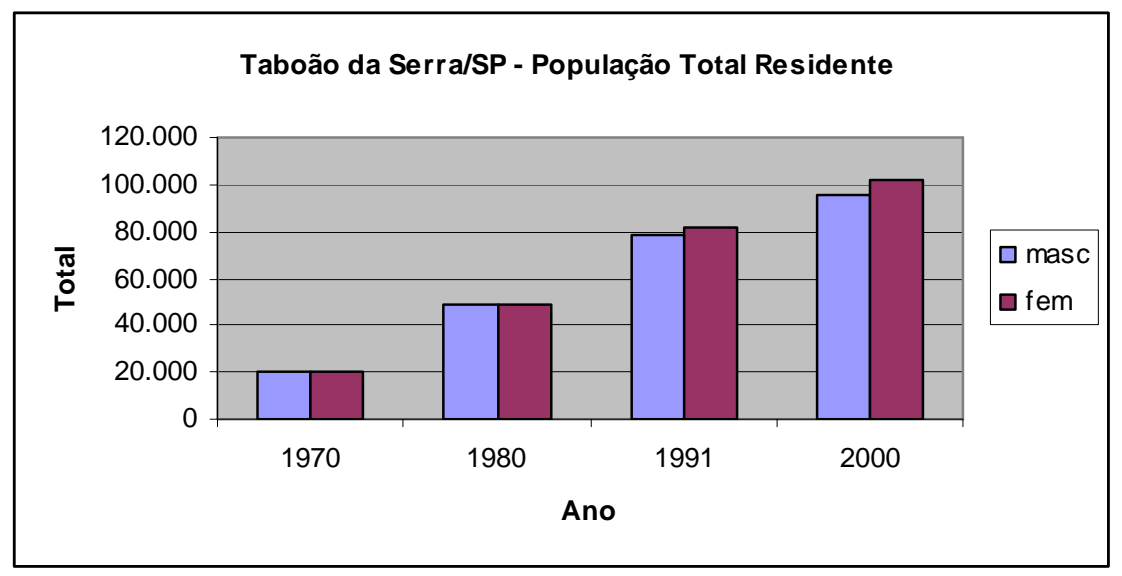

Fig. 28 - População total residente Fonte: IBGE/Muninet

Em Taboão da Serra, com relação à sua diminuta área, o povoamento deu-se de forma desordenada $e$ intensa. A proximidade com a capital colaborou para que o núcleo urbano que ai se instalou, tivesse duas características básicas: a de cidade dormitório e com o passar dos anos a de fixação contínua de núcleos industriais paralelos à rodovia Régis Bittencourt, o que facilita sobremaneira o transporte e escoamento da produção. 
Tab. 10-Evolução da população residente em Taboão da Serra/SP, no período de 1970-2007.

\begin{tabular}{l|c}
\hline ANO & URBANA/TOTAL ${ }^{16}$ \\
\hline 1970 & 40.945 \\
1980 & 97.656 \\
1991 & 160.084 \\
2000 & 197.644 \\
$2007^{*}$ & 228.010 \\
\hline
\end{tabular}

Fonte: IBGE, Censo Demográfico 1970, 1980, 1991, 2000

* Estimativa Populacional, Anuário Estatístico de São Paulo, 2006

O contingente populacional, seguindo uma tendência nacional teve um crescimento contínuo, sendo que a população residente feminina fosse ligeiramente maior principalmente a partir da década de 1990. Numa área total de $20 \mathrm{~km}^{2}$, a população total residente saltou de aproximadamente 40.945 habitantes na década de 1970 para aproximadamente 197.644 habitantes no ano 2000, provocando uma intensificação do uso da terra essencialmente urbana.,

Por situação de domicílio, entende-se que as características econômicas e sociais de Taboão da Serra repercutem na dinâmica demográfica como ficou claro nas tabelas elaboradas. Uma característica marcante na distribuição da população do município, é a natureza de sua espacialização. Tomando como característica os tipos de construções e a densidade das mesmas, observa-se que:

16 O município não apresenta área rural, portanto não apresenta população desta natureza. 
- Às margens da rodovia Régis Bittencourt, encontram-se residências de mais de 1 pavimento e com arquitetura diferenciada, demonstrando um cuidado maior com a estrutura e com o acabamento. Como exemplos os bairros INTERCAP e PARQUE PINHEIROS, apresentam uma concentração de construções mas, demonstram visualmente um cuidado maior com o tipo de material usado na elaboração das moradias, e na preservação de algumas áreas verdes remanescentes.

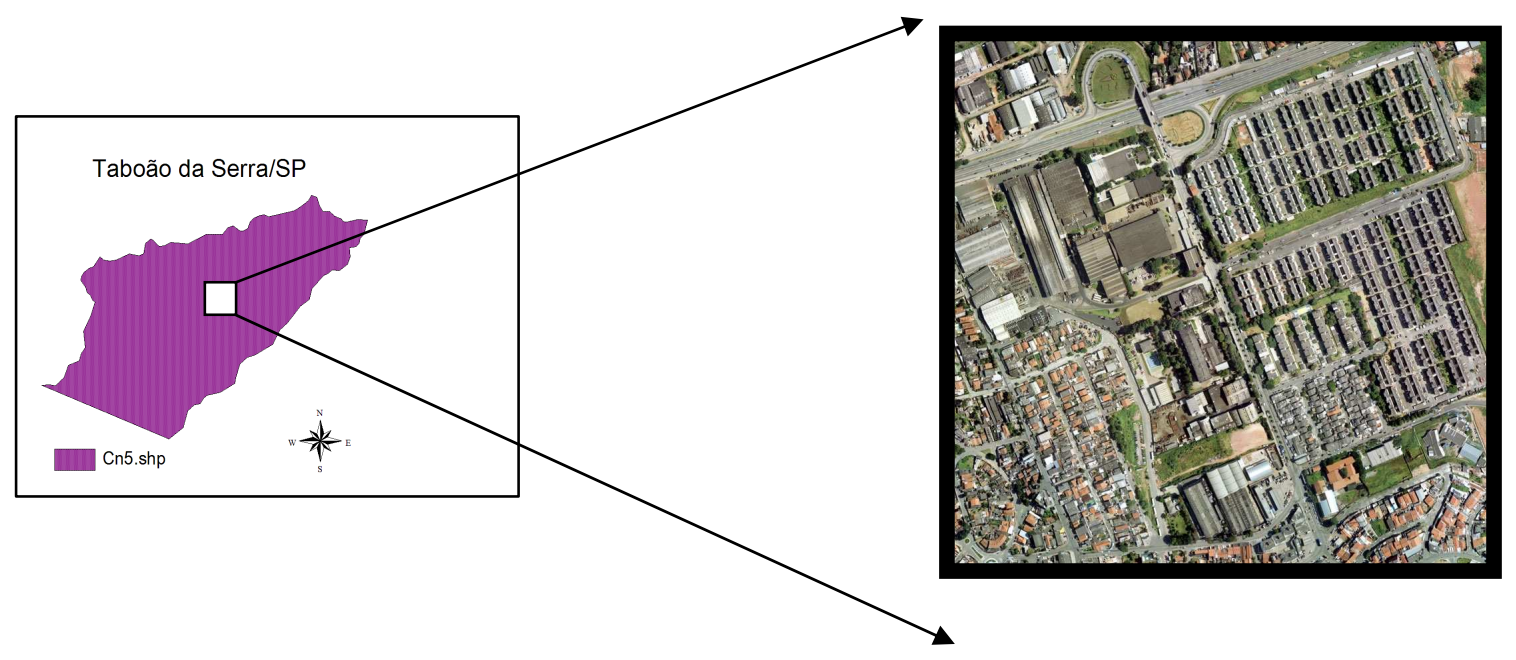

Fig. 29 - Área do Parque Pinheiros - Construções com melhor nível de elaboracão e acabamento, à direita Coniunto Habitacional Popular

- Apesar do relevo da cidade ser o mesmo na sua totalidade (áreas de morrarias, recortadas no sentido sudoeste/nordeste pela rodovia) observa-se que as vertentes ${ }^{17}$ dos bairros ocupados pelas classes $A$ e $B$ apresentam obras de contenção mais elaboradas, modificando profundamente a dinâmica das encostas;

17 Tomamos aqui a definição dada por Jan Dylik in CHRISTOFOLETTI (1980) sobre vertente: "...forma tridimensional que foi modelada pelos processos de denudação, atuantes no presente ou no passado, e representando a conexão dinâmica entre o interflúvio e o fundo do vale...". 
- Afastando-se do eixo da rodovia no sentido SE, proliferam as construções de 2 ou mais pavimentos, ocupando áreas menores, mas com um adensamento mais elevado que os bairros das classes $A$ e $B$. As vertentes nestas áreas apresentam-se desprovidas de proteção natural ou com contenção.

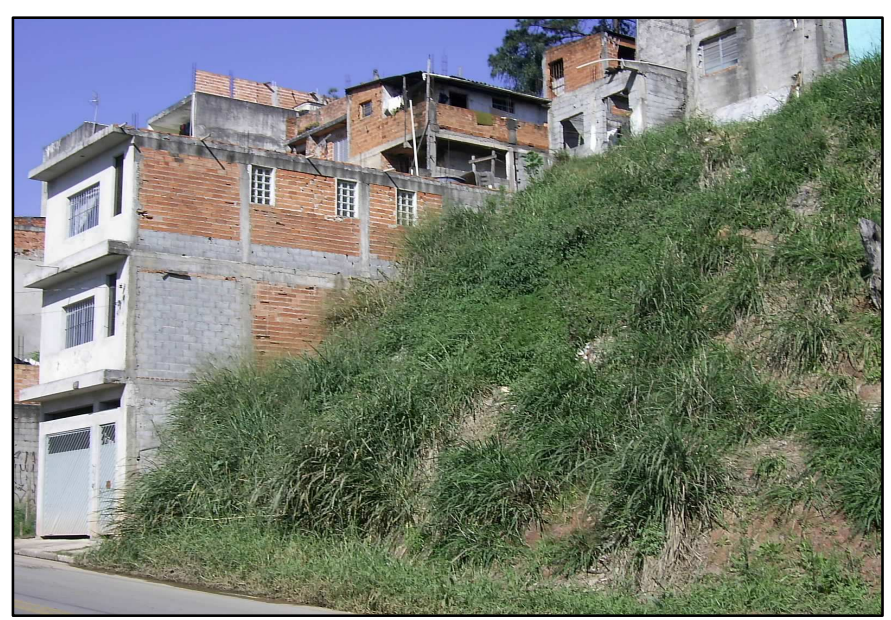

Foto.27 - Ocupação de encostas - Vila Indiana

Os bairros próximos ao córrego Pirajussara, tem todos como característica áreas baldias com ocupação de entulhos, concentração de lixo urbano, entulhamento do talvegue do córrego por lixo domiciliar, como também pelo mato que cresce no seu interior.

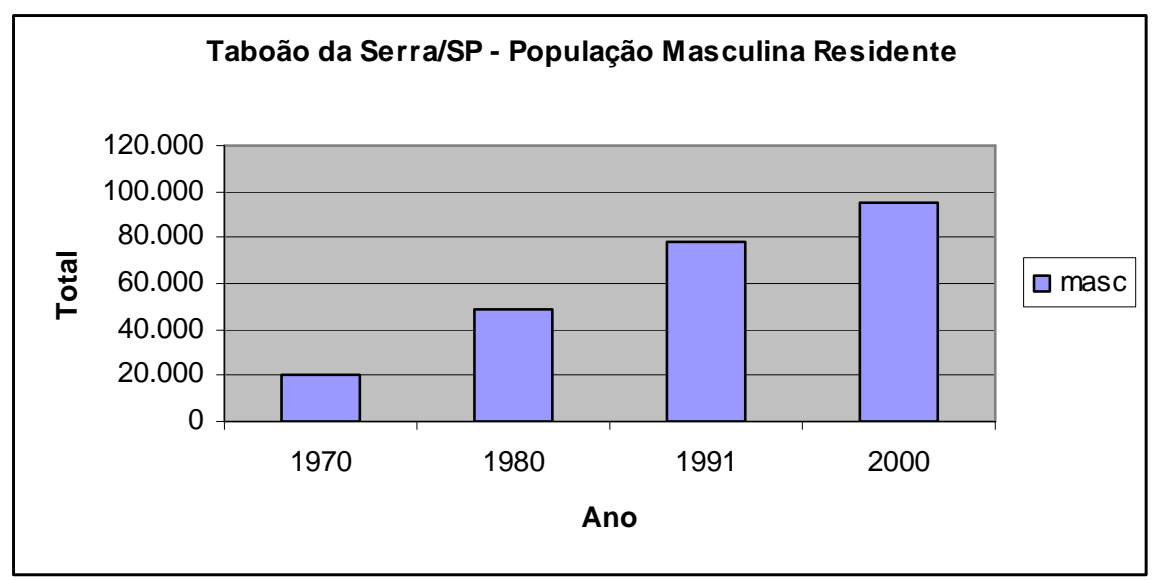

Fig.30-População masculina residente Fonte: IBGE/Muninet 
Tabela 11-Evolução da população residente em Taboão da Serra/SP, por situação de domicílio e sexo no período de 1970-2007.

\begin{tabular}{l|c|c|c}
\hline ANO & HOMENS & MULHERES & TOTAL \\
\hline 1970 & 20.603 & 20.342 & $\mathbf{4 0 . 9 4 5}$ \\
1980 & 49.087 & 48.569 & $\mathbf{9 7 . 6 5 6}$ \\
1991 & 78.430 & 81.654 & $\mathbf{1 6 0 . 0 8 4}$ \\
2000 & 95.357 & 102.287 & $\mathbf{1 9 7 . 6 4 4}$ \\
$2007^{*}$ & 110.360 & 119.920 & $\mathbf{2 3 0 . 2 8 0}$ \\
\hline
\end{tabular}

Fonte: IBGE, Censo Demográfico 1970, 1980, 1991, 2000

* Estimativa Populacional,

Anuário Estatístico de São Paulo, 2006

Nota-se que, a população residente masculina tem um comportamento diferente, quando se trata do crescimento da população residente do sexo oposto. A tabela mostra uma significativa evolução desde a década de 1970, mas sem apresentar um aspecto de evolução geométrica. Tal aspecto também evidencia o que ocorre em termos nacionais, quando por exemplo se compara a porcentagem dos dois sexos na composição da população total, sendo sempre positiva ou a mais para o sexo feminino.

A tabela acima comprova algumas características da evolução da população feminina residente na cidade, desde a década de 1970, houve um crescimento geométrico deste montante sendo que, até 1990 este comportamento foi praticamente constante. 
Adentrando a década de 1990, o comportamento começou a modificar-se do ponto de visa do crescimento geométrico, tal população iniciou um processo de desaceleração passando a não dobrar num período de 10 anos mas, sim a apresentar um crescimento que representa agora a metade do que acontecia anteriormente.

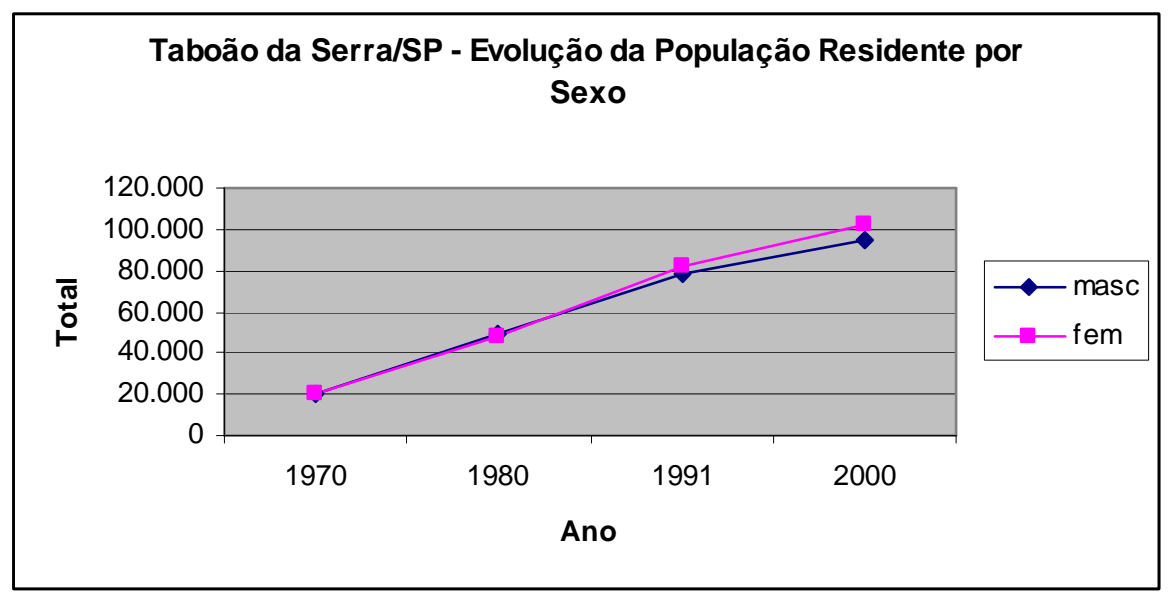

Fig.31- Evolução da população por sexo Fonte: IBGE/Muninet

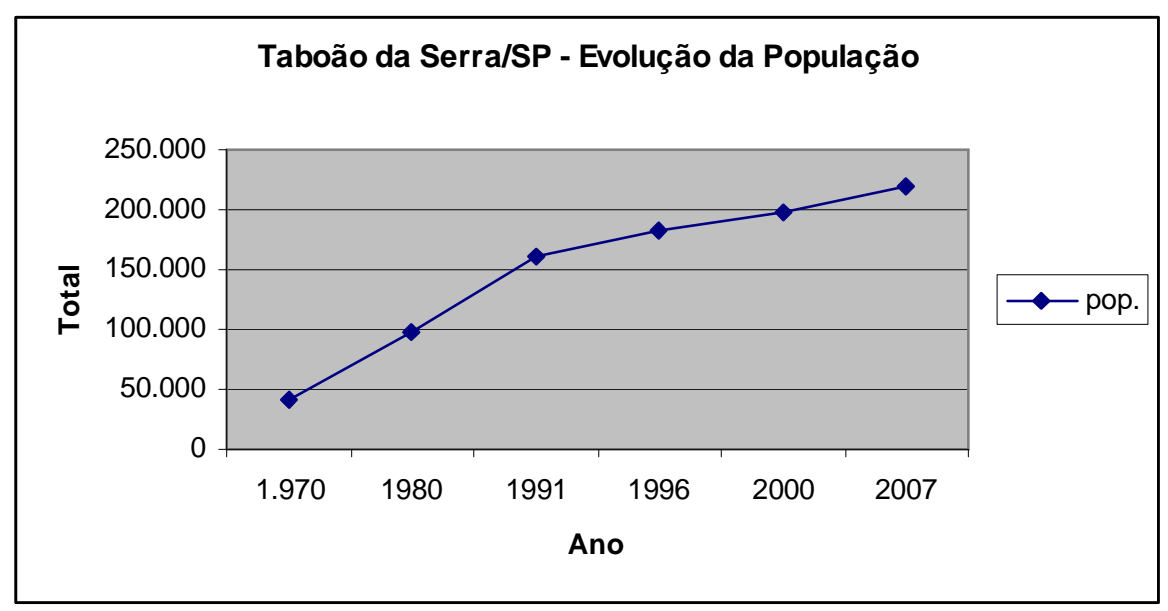

Fig.32- Evolução da população Fonte: IBGE/Muninet 


\subsection{Intervenções públicas: 0 plano diretor do município}

A elaboração do Plano Diretor de Taboão da Serra teve seu início com a mudança da gestão municipal no período marcado entre 2004/2005. O Plano faz parte de um conjunto de leis federais, estaduais e municipais que ditam as regras para o desenvolvimento urbano.

Pode se definir o Plano como um conjunto de leis em nível municipal, que organiza o crescimento e o funcionamento da cidade e depois de ser elaborado, de preferência de forma democrática com a participação dos munícipes, deve ser aprovada pela Câmara Municipal de Vereadores.

Esta lei, que reúne as diretrizes de como o município deve se desenvolver em termos de uso e ocupação do solo, expressa que tipo de cidade irá se construir para o futuro, onde a organização desse crescimento e desenvolvimento indicará uma positiva gestão do território.

O Plano foi elaborado sob a coordenação da Secretaria Municipal de Habitação, sendo assessorada pela FAU/USP. O empreendimento veio com a necessidade premente de atender à uma lei federal, que determina a urgente elaboração de leis de uso do solo, o que é exposto no Estatuto das Cidades ${ }^{18}$.

A urgência da elaboração do Plano vem para evitar sérias conseqüências ao município, dentre as quais, caso se não fosse aprovado a tempo poderia trazer sérios prejuízos financeiros a Taboão da Serra, como por exemplo, o município

18 ESTATUTO DAS CIDADES: Lei $\mathrm{n} \cong$ 10.257, de 10 de julho de 2001 , para todos os efeitos, esta Lei, denominada Estatuto da Cidade,estabelece normas de ordem pública e interesse social que regulam o uso da propriedade urbana em prol do bem coletivo, da segurança e do bem-estar dos cidadãos, bem como do equilíbrio ambiental. 
ficar impedido de receber determinados recursos do governo federal.

Aprovado em 10 de Outubro de 2006, o Plano Diretor, recebeu críticas de grupos sociais organizados como o MTST (Movimento dos Trabalhadores Sem-Teto), que exigiu mudanças, principalmente no que diz respeito às ZEIS (Zonas Especiais de Interesse Social).

A elaboração do Plano Diretor Municipal, tomou como referencial a Base Cartográfica do Município na escala 1: 20.000 a partir de ortofotos. Sendo assim, elaborou-se um zoneamento para o território municipal apresentando características especiais que serão apresentadas nos tópicos a seguir.

\subsubsection{Sistema de Áreas Verdes do Município}

Criada pela lei complementar no 132 de 26/12/2006: Segundo o plano diretor, estas áreas são aquelas classificadas como APA (Área de Proteção Ambiental), sendo às mesmas prioritárias e cumprem um papel estratégico para a estruturação urbana e ordenamento do território. Este é o sistema que mais sofreu impactos com relação ao avanço da urbanização.

Este sistema tem como característica a concentração de remanescentes de mata atlântica intercaladas com araucárias, localizavam-se em todo o território municipal, encontrando-se agora algumas manchas espaçadas ao longo da Rodovia Régis Bittencourt e principalmente a noroeste do município.

A maior mancha de conservação de áreas verdes, observando-se a carta de evolução de uso do solo para o ano de 2007 no entanto, encontra-se em uma área particular fechada (Condomínio Jardim Yolanda) a noroeste do município. 


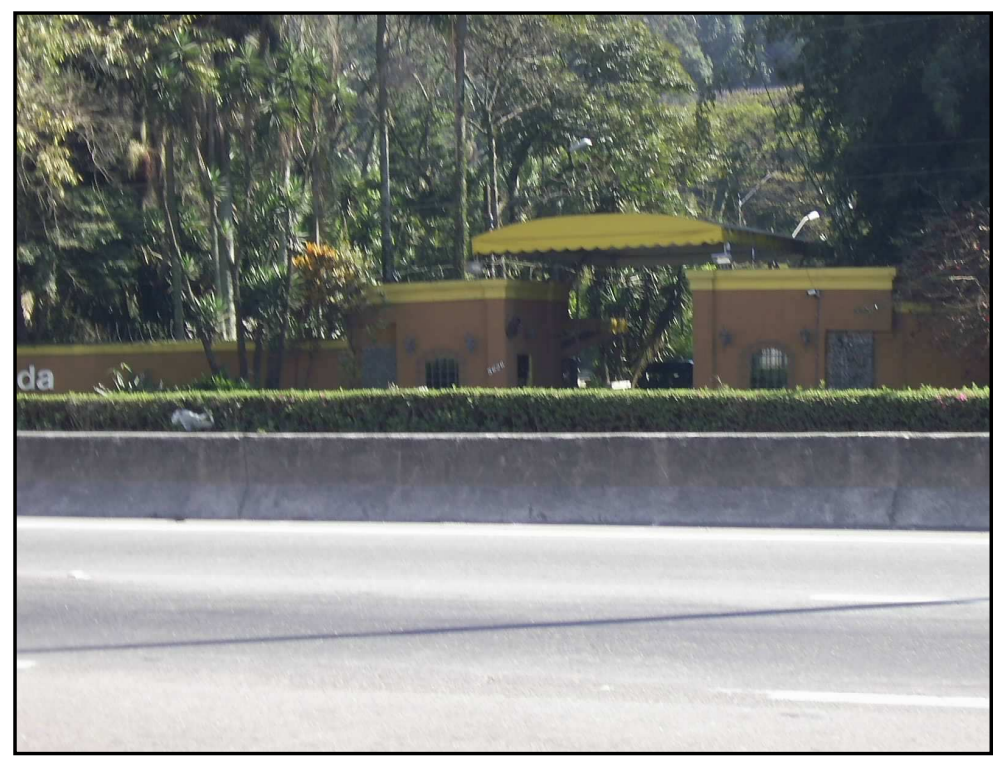

Foto 28 - Maior remanescente de mata atlântica do município (Jardim Yolanda)

-Podem ser classificados em 11 áreas especiais de interesse e proteção:

À direita da rodovia estadual Régis Bittencourt, no sentido Curitiba/PR:

- Parque Poá I (Entre as ruas Santa Luzia e Jovina de Carvalho Dau);

- Parque das Hortênsias (Meio da av. José André de Moraes); 


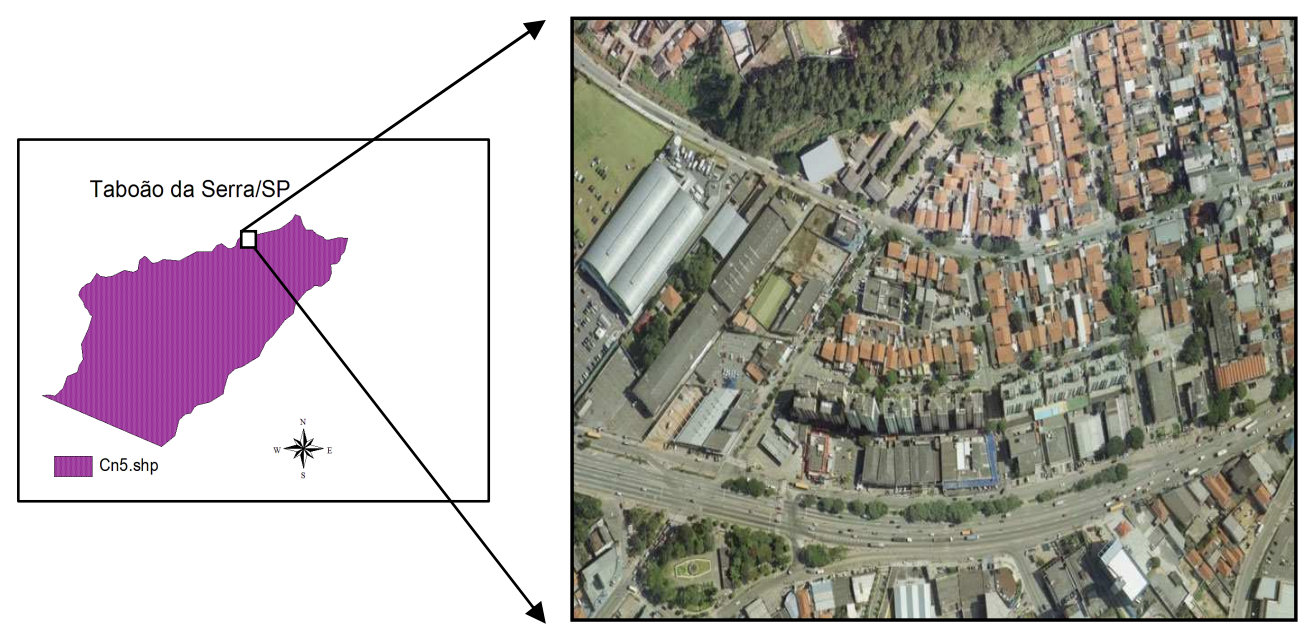

Fig.33 - Parque Poá I ao alto e vista aérea da Régis Bittencourt, trecho urbano no centro de Taboão da Serra parte inferior.

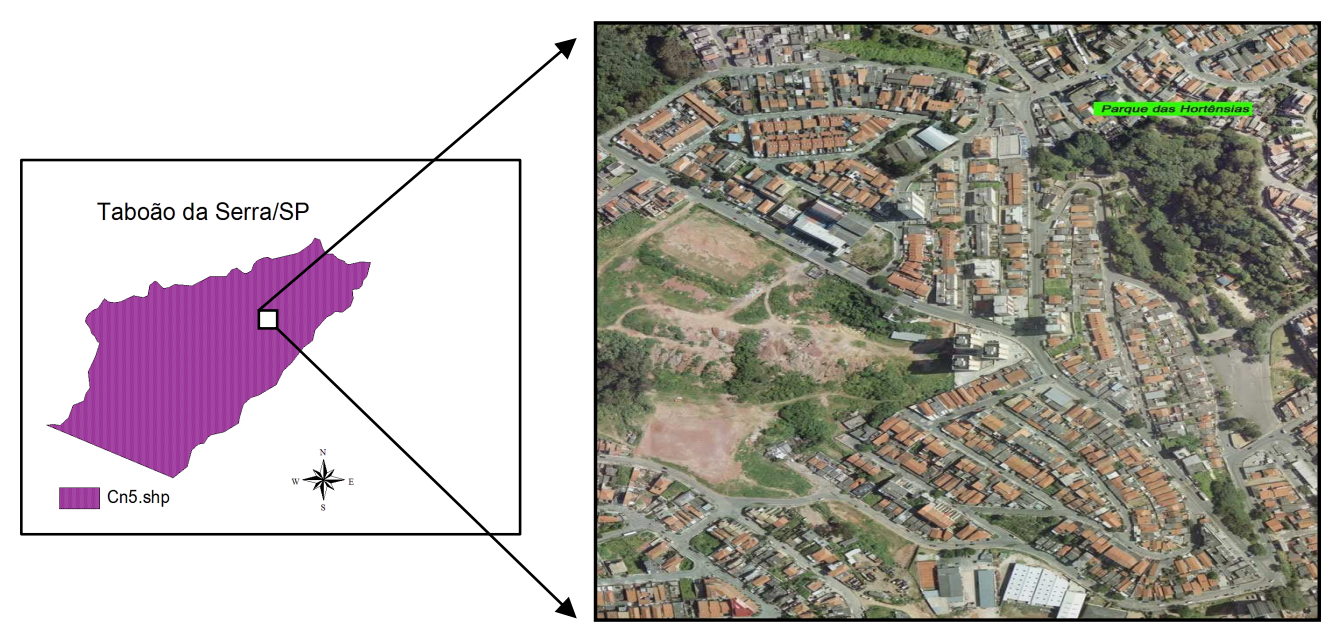

Fig.34- Fotografia aérea- Taboão da Serra - Bairro Parque das Hortênsias-06/2005 - Zona mista de ocupação - classes A,B e C. cobertura do solo por concreto e grandes áreas sem cobertura vegetal.

- Parque Poá II (Início da Av. José André de Moraes);

- Parque Poá III (Início da Av. Mal. Castello Branco com a Régis Bittencourt);

- Parque Ecológico (Av. Heitor Antonio Eiras Garcia); 
$>$ À esquerda da rodovia estadual Régis Bittencourt, no sentido Curitiba/PR:

- Parque do Pirajuçara I (Imediações da rua José Carlos de Moraes);

- Parque Pirajussara II (Imediações da estrada de São Francisco e Shopping Taboão);

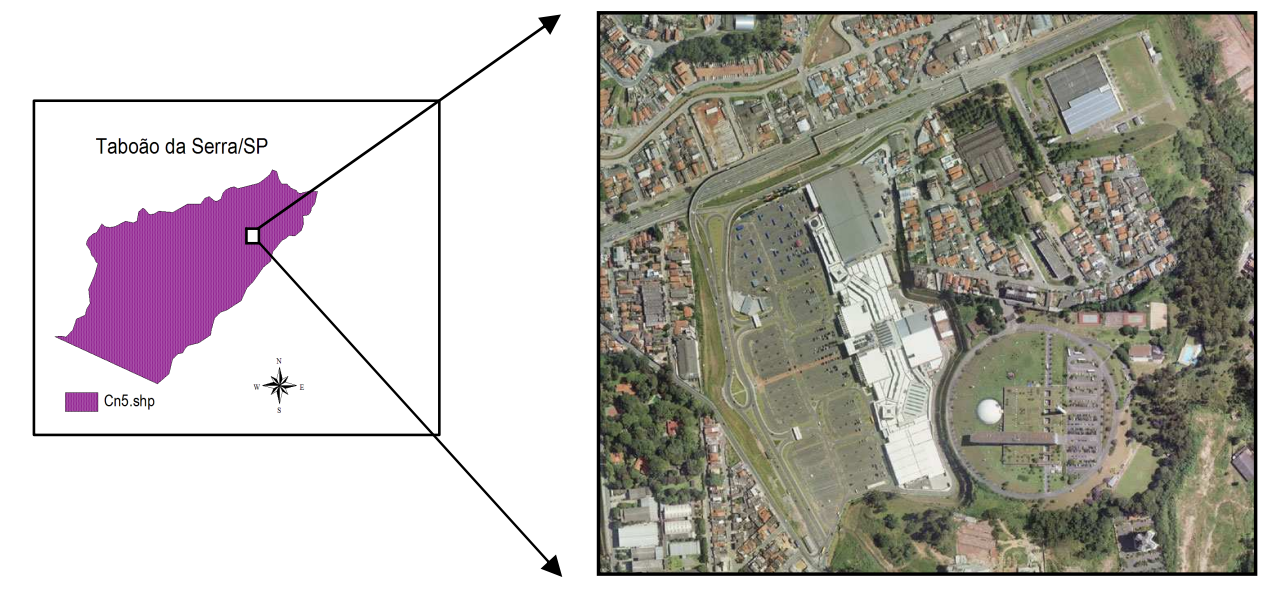

Fig. 35 - Parque Pirajuçara II - Arredores do shopping Taboão: Uso intenso do solo.

- Parque Pirajuçara III (Início da rua Teófilo Ottoni);

- Parque Pirajuçara IV (Imediações do córrego Jardim Cachoeira);

- Parque Central (Entre as ruas Vicente Leporace e Av. Cid Nelson Jordano). 


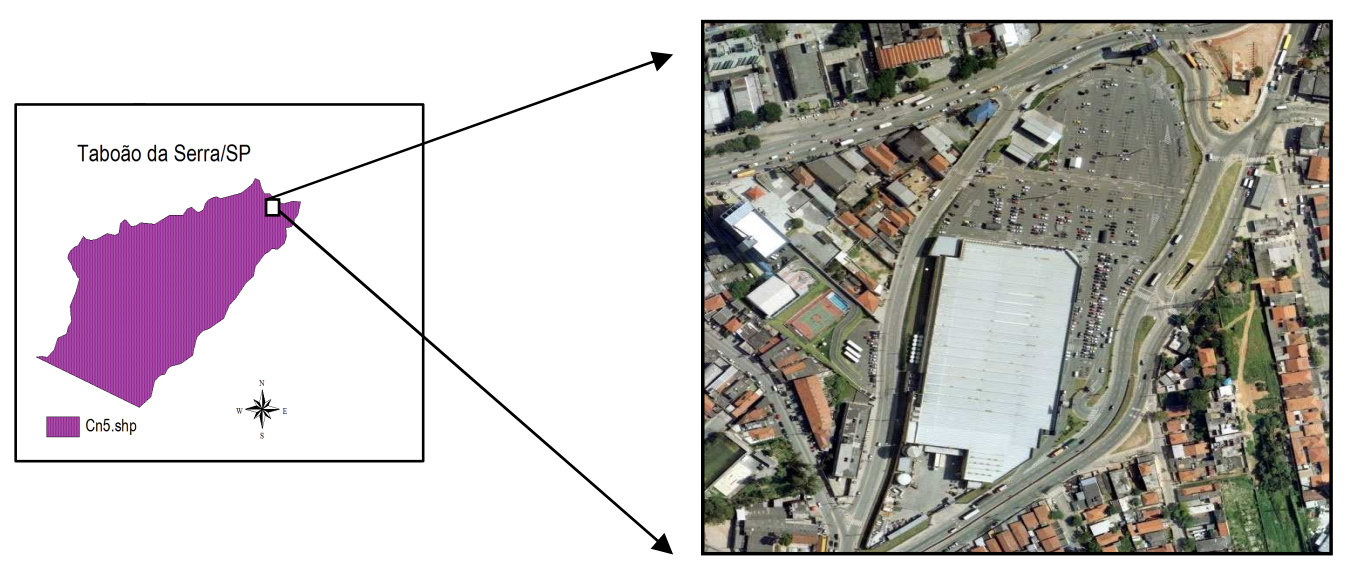

Fig.36 - Exemplo de uso intenso do solo urbano: cobertura asfáltica: Entorno do Supermercado Extra.

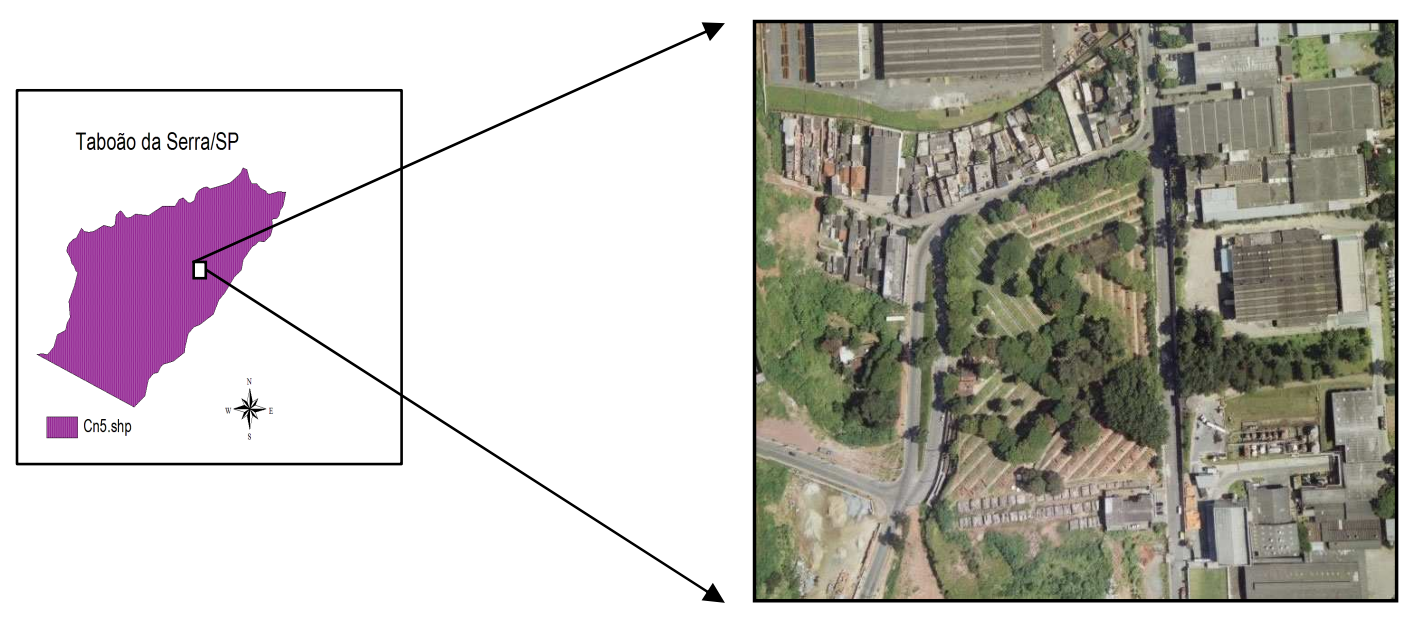

Fig.37 - Remanescente de área verde intra-urbano: Cemitério da Saudade - Parque Pinheiros, cercado por áreas industriais. 
7.2.2 Zonas Especiais de Interesse Social: Lei complementar no 176 de $03 / 02 / 2009$

Assim considerada 2 zonas caracterizadas pela ocupação, ambas de forma não ordenadas. Sendo a ZEI 1 uma área de interesse público por se caracterizar como sendo uma área de alta densidade demográfica e de cobertura do solo ocupando grande parte do sudoeste do município. A ZEI 2, é a segunda área de interesse público do município, abrangendo áreas de remanescentes da mata com escassa ocupação do solo.

-Podem ser classificados em 02 áreas especiais de interesse :

ZEIS 1 - Zona Especial de Interesse 1: que abrange $80 \%$ das zonas de interesse social. São as áreas públicas ou privadas, ocupadas por população de baixa renda, de interesse público, na promoção da regularização urbanística e fundiária. E são classificadas como sendo:

$\checkmark$ Favelas;

$\checkmark$ Habitações coletivas precárias;

$\checkmark$ Parcelamento e loteamentos irregulares;

$\checkmark$ Conjunto habitacional de promoção pública;

$\checkmark$ Conjunto de unidades habitacionais precárias

$>$ ZEIS 2 - Zona Especial de Interesse 2: que abrange 20\% das citadas áreas. São as áreas com predominância de imóveis adequados à urbanização, de interesse público na promoção de Habitação de Interesse Social (HIS) para famílias de baixa renda que não possuam moradia. E são classificadas como sendo: 
$\checkmark$ Os imóveis não edificados ou subutilizados com potencial de ocupação por Habitação de Interesse Social (HIS).

Segundo o Plano Diretor do Município de Taboão da Serra/SP, as áreas demarcadas como ZEIS (Zona Especial de Interesse Social) destinam-se a:

$\checkmark$ Recuperação urbanística;

$\checkmark$ Regularização urbanística e fundiária;

$\checkmark$ Produção de HIS (Habitação de Interesse Social);

$\checkmark$ Recuperação de imóveis degradados, ou em condições precárias de habitabilidade;

$\checkmark$ Desadensamento de assentamentos precários e de coabitações;

$\checkmark$ Provisão de espaços públicos e equipamentos sociais, comércio e serviços de caráter local, complementares à moradia;

$\checkmark$ Provisão de espaços de capacitação profissional e de atividades de geração de emprego e renda.

As ZEIS do tipo 1 tem como principal problemática a ocupação intensiva do solo, o que obriga a prefeitura a organizar o uso, tendo em vista que as construções ocorreram de modo aleatório no passado invadindo áreas de risco e principalmente as áreas de várzeas. 


\subsection{3 Áreas Sujeitas ao Direito de Preempção ${ }^{19}$ : Lei} complementar no 132 de 26/12/2006:

- Estas áreas são demarcadas com base no direito do município sobre áreas ou construções no caso de ter preferência para compra ante particulares. Existem atualmente 28 áreas demarcadas como de direito de preempção pela prefeitura municipal de Taboão da Serra.

\subsection{4 Áreas Homogêneas:}

A lei complementar no 132 de 26/12/2006: Segundo o plano diretor municipal as Áreas Homogêneas são porções do território delimitadas para fixar as regras do ordenamento territorial, tendo como referência as características dos ambientes natural e construído.

As áreas homogêneas são classificadas como sendo um tipo de ordenação do uso do solo com base em critérios sócioeconômicos. Sendo assim, classificam-se as áreas com homogeneidade industrial, habitacional e de preservação.

No que se refere à homogeneidade, percebe-se que as características da ocupação do solo pela população de baixa renda difere de outras classes no quesito urbanização, surge daí a problemática de reestruturar áreas de consolidação antiga com base num novo critério de organização do uso do solo (Plano Diretor).

${ }^{19}$ O direito de preempção é um instrumento jurídico de política urbana que confere ao poder público municipal, preferência para a compra de imóvel urbano, respeitado seu valor no mercado imobiliário antes que o imóvel de interesse do município seja comercializado entre particulares. MundoGeo (13/09/2007). 
- Atualmente existem 4 tipos áreas homogêneas na área territorial municipal que são:

$\checkmark$ Área homogênea de desenvolvimento econômico: caracterizada pela atividade industrial e comercial. Esta área encontra-se quase que totalmente às margens da Rodovia Régis Bittencourt, onde estão implantas algumas das mais importantes indústrias de transformação do município e do estado como: de bens de consumo duráveis e não-duráveis (CINPAL, RISQUÉ, etc.);

$\checkmark$ Área homogênea de proteção ambiental: caracterizada pela manutenção e proteção das APA's, onde remanescentes de vegetação nativa ainda subsistem entre as construções. Esta mancha encontra-se quase que totalmente à margem direita da Rodovia Régis Bitencourt, tendo seu início na Rua José André de Moraes indo até à divisa desta cidade com o município de Embu;

$\checkmark$ Área homogênea de urbanização consolidada: caracterizada pela área construída do município, a implantação dessas áreas tem como objetivos principalmente o de melhorar a qualidade dos espaços públicos e do meio ambiente, estimular as atividades de comércio e serviços, implantação do sistema viário do município, preservação da qualidade urbana das áreas residenciais já consolidadas, estimular a implantação de novos empreendimentos, controlar o adensamento ou a saturação viária. 


\section{$\checkmark$ Área homogênea de urbanização precária: refere-se} às áreas do município que não dispõe de um atendimento urbano regular. Estas áreas insere-se na proposta da prefeitura que propõe sua regularização e urbanização. O governo municipal objetiva qualificar os assentamentos já existentes minimizando os impactos decorrentes das ocupações irregulares no território. De um modo geral a área classificada como de urbanização precária estende-se totalmente na parte sul do território do município.

O Plano Diretor de Taboão da Serra, atende à uma orientação em nível nacional, da necessidade de implantação de leis que regulamentem o uso da terra, principalmente urbano.

No caso da área de estudo, esta implantação esteve atrelada à uma situação política. Juntamente com a implantação do Plano Diretor, houve também a fundação do Diário Oficial do Município, onde são divulgados os resultados do mapeamento da área municipal. Este fator torna-se positivo porque demonstra uma preocupação por parte do poder público com a questão do conhecimento cartográfico do município.

Há agora implantado um setor de gerenciamento de obras públicas e de melhorias, principalmente com relação à ocupação das encostas, embora, a secretaria de obras públicas opte ainda, pelo antigo método de construção de muros de contenção, em especial nas áreas mais afastadas do centro (periferia) que coincide como sendo as áreas mais íngremes e densamente povoadas (Foto 29). 


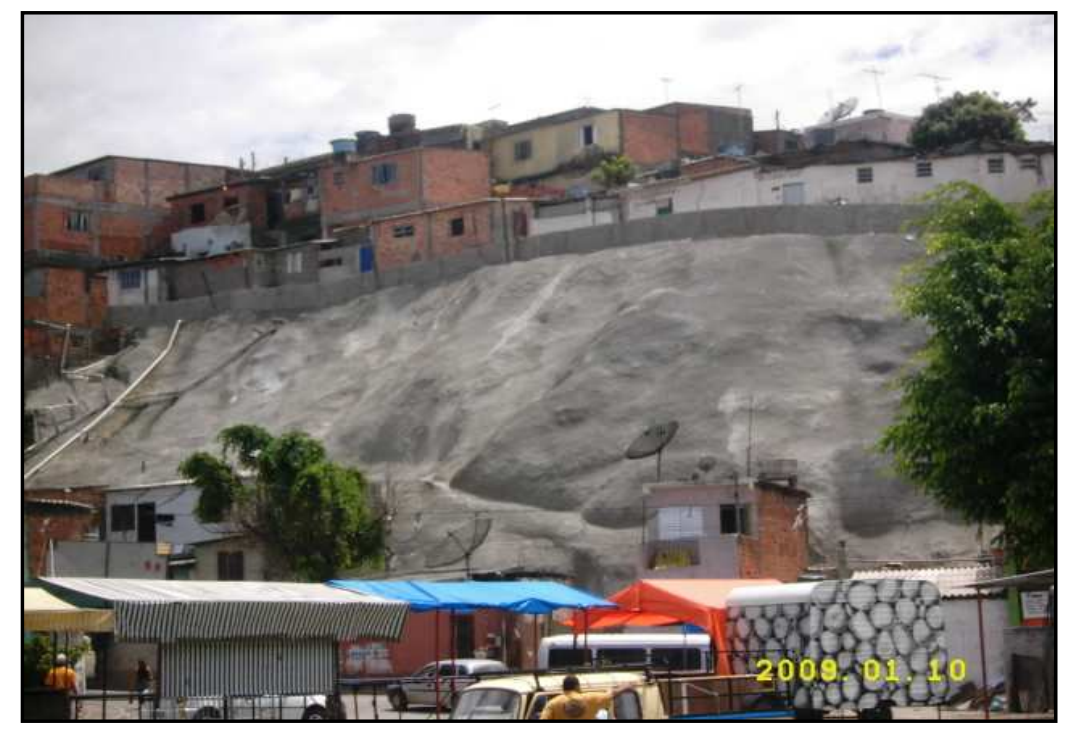

Foto.29 - Encosta com contenção superficial de cimento e muro de arrimo em concreto. Bairro Pirajussara.

Como ponto de partida o Plano Diretor veio para organizar e gerenciar as futuras ocupações e construções, embora, o que já está ocupado deu-se de forma desorganizada, como resultado temos grandes espaços onde as ocupações se deram de forma indiscriminada, tanto em extensas e íngremes encostas, como também em áreas próximas das várzeas dos principais córregos.

Atualmente existe o confronto direto entre Poder Público e População, sendo que a primeira tenta impor pela força o respeito às novas leis de uso e ocupação.Tal confronto acontece principalmente nas áreas mais pobres (São Judas, às margens da avenida Kizaemon Takeuti), onde já foram desocupadas grandes extensões onde antes existiam inúmeros "barracos" já construídos. 


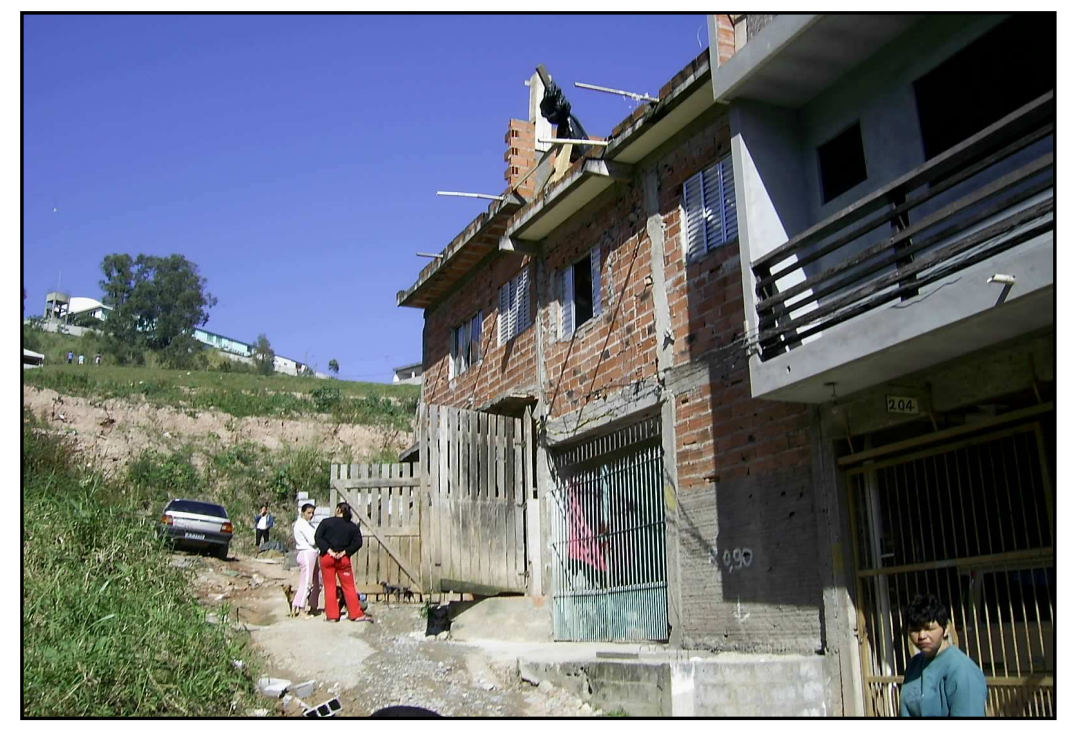

Foto 30 - São Judas - Área ao fundo desocupada com aplicação de força nolicial.

Torna-se essencial no momento, a assistência do Poder Público para com a população mais carente, principalmente no que tange à assistência social e à construção de moradias de melhor padrão em áreas propícias. Estas ações são ainda realizadas por empresas particulares que se sobrepõem à esfera pública, realizando empreendimentos para as classes $B$ e $C$ localizadas em áreas que antes era de ocupação das classes $D$ e E (Foto 32 ). 


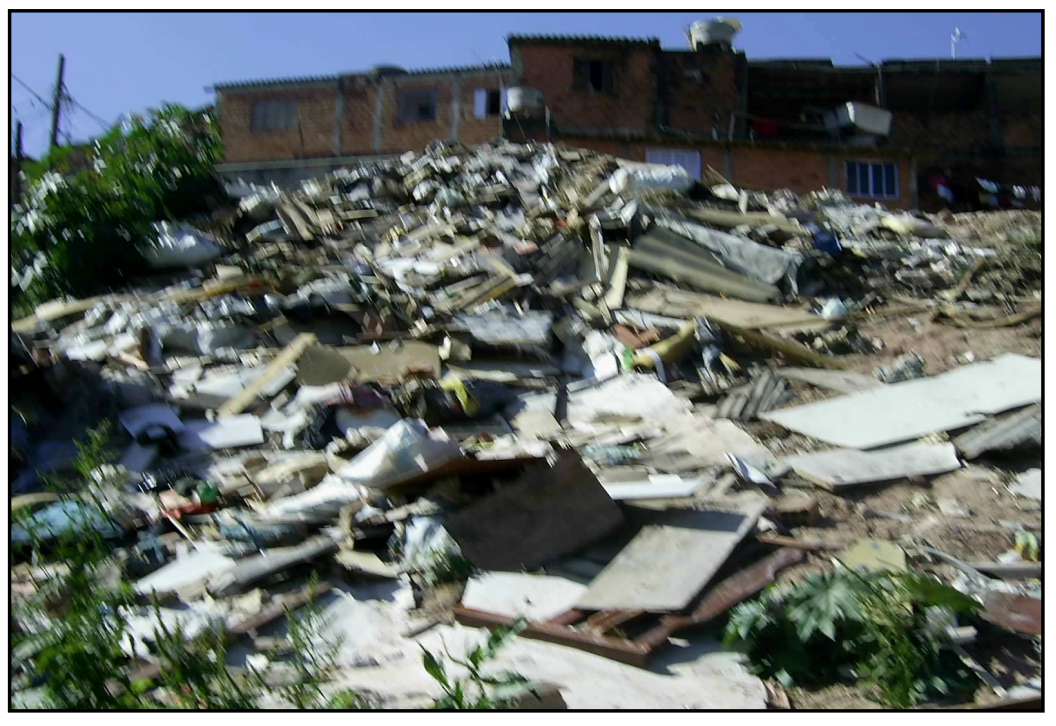

Foto 31 - São Judas - Área desocupada

- Destroços de construções após aplicação de força policial

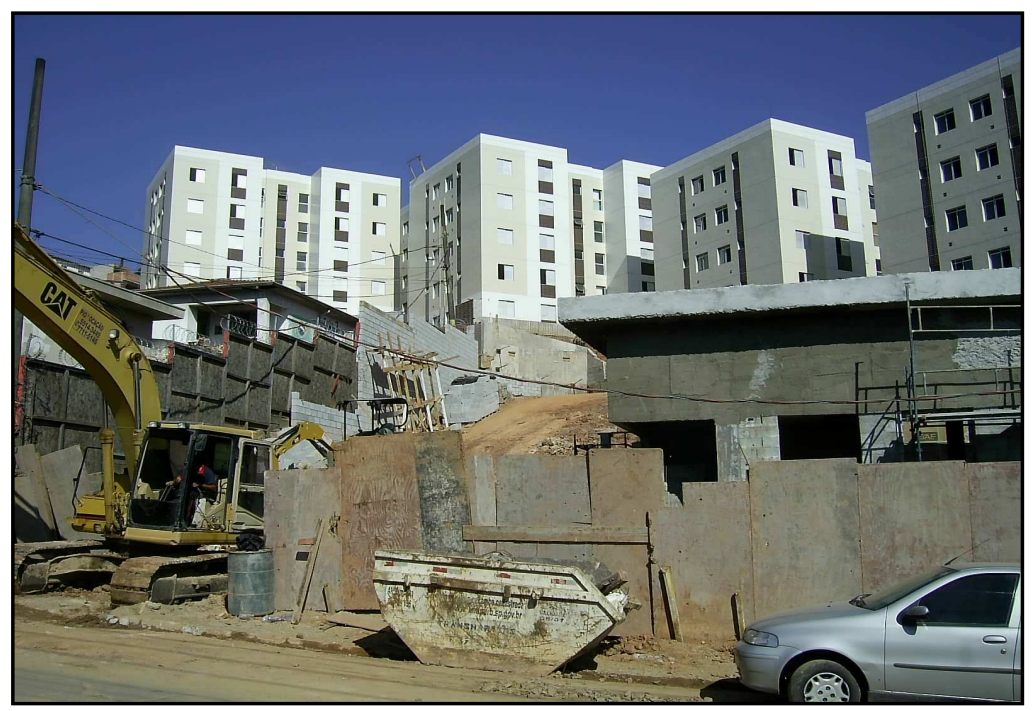

Foto 32 - Vila Indiana - Desocupação e ocupação por empreendimentos particulares.Construtora Tenda. 
8. EVOLUÇÃO URBANA

(1962 A 2007) 


\subsection{EVOLUÇÃO URBANA DE TABOÃO DA SERRA}

A base cartográfica da área de estudo foi digitalizada e vetorizada a partir das cartas topográficas em escala 1:50.000 do IBGE, compreendendo a cobertura das folhas SF-23-Y-V-VI-2 (São Paulo), que ainda contém a rede hidrográfica, as curvas de nível com pontos cotados, sendo que as $C N$ tem eqüidistância de 20 metros.

Os temas selecionados e trabalhados correspondem no Banco de Dados a um arquivo do tipo "shapefile" contendo as seguintes descrições:

- HIDROGRAFIA- São representados por vetores do tipo linha correspondentes à rede de drenagem fluvial de margem simples. Seguindo como arquivo correlatos temos uma tabela de atributos com suas toponímias ou seja, com os nomes de cada canal de acordo com a carta topográfica;

- CORPOS D’ÁGUA- São representados por vetores do tipo polígono, correspondente à rede de drenagem fluvial de margem dupla e represas. A tabela de atributos contém um campo que apresenta a toponímia de acordo com a carta topográfica;

- SUMIDOUROS-Vetores do tipo linha que representam os lugares em que a drenagem se torna subterrânea;

- PONTOS COTADOS- Vetores representados do tipo ponto. A tabela de atributos contém um campo com a cota altitude;

- CURVAS DE NIVEL- Vetores do tipo linha. A tabela de atributos contém um campo com a cota de altitude e um campo com a hierarquia de cada curva; 
Com relação à rede de drenagem, faz-se necessário destacar as características atuais, principalmente do córrego Pirajussara, que encontra-se em alguns pontos totalmente degradado, apesar das obras de canalização, que diminuiu a largura do córrego, fato que é agravado pela excessiva antropização representado principalmente pelo lançamento de esgotos e lixo no canal (Foto 33).

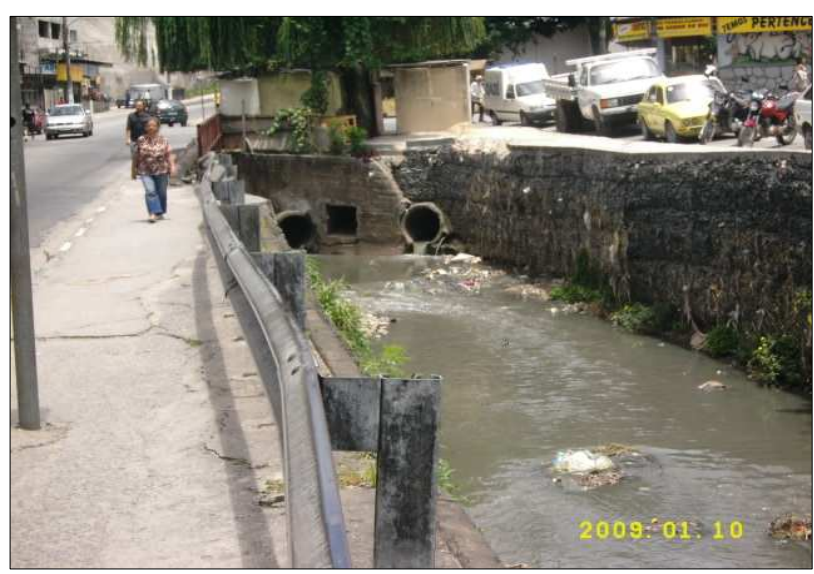

Foto33 - Pirajussara/Taboão:Córrego homônimo com esgotamento doméstico, concentração de lixo e proximidade de edificações no seu leito. 
Fin 38 TABOÃO DA SERRA/SP-CURVA DE NIVEL E HIDROGRAFIA
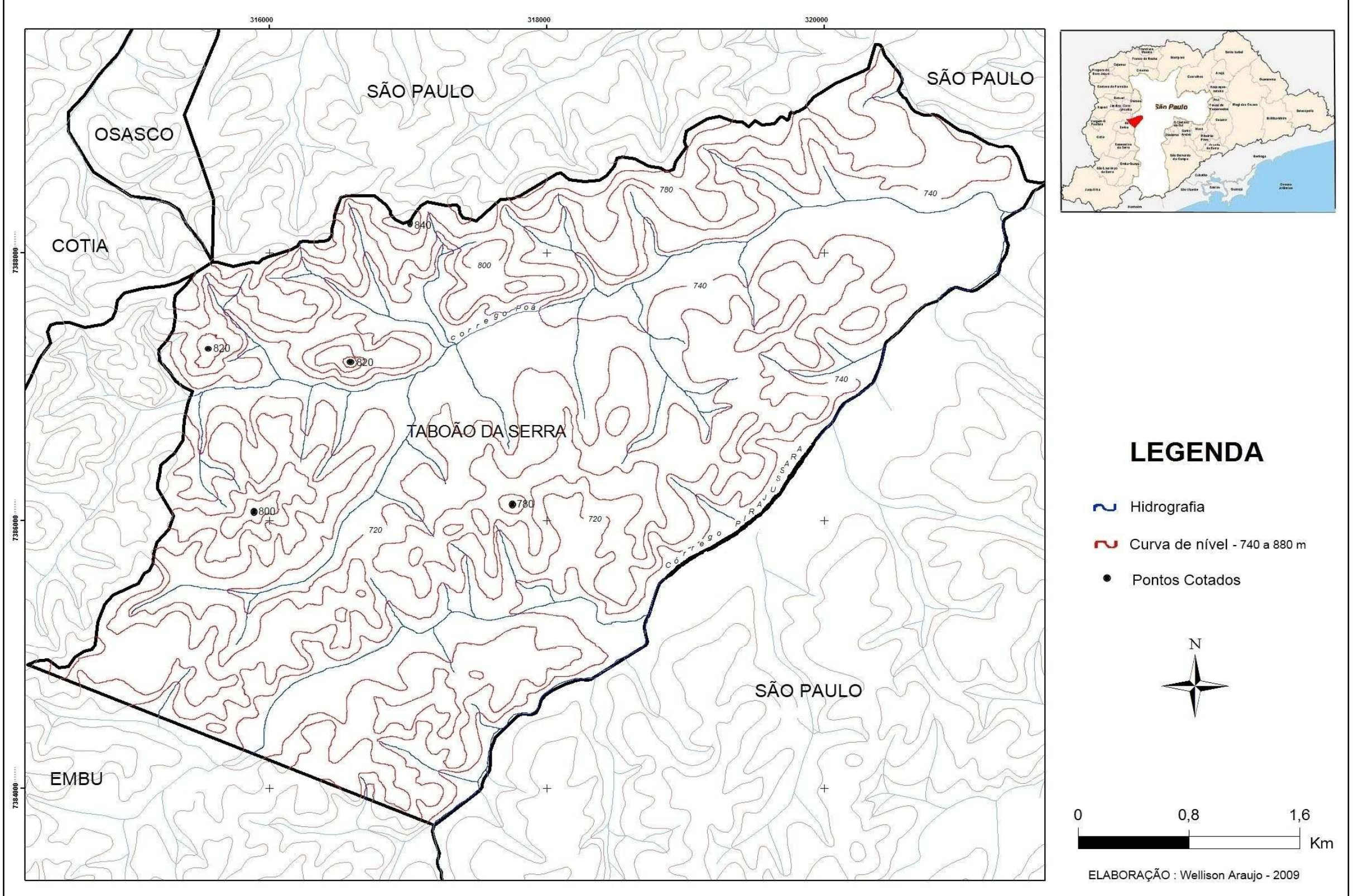

Fig.27 Perfil esquemático NW/SE - Taboão da Serra/SP 
Através da visualização da disposição das curvas de nível mestras, percebe-se a ocorrência de terrenos acidentados que é revelado pelo distanciamento das curvas (20 em 20 metros) (Fig.38).

As curvas secundárias revelam ainda mais os grandes declives existentes na cidade, onde o seu território apesar de relativamente pequeno em extensão, possui solos evoluídos a partir de rochas antigas, bem desenvolvidos e com alta concentração de material argiloso.

O embasamento do território sofreu as transformações que reinaram sob ações climáticas que trabalharam na construção das formas que apesar de acidentadas, eram protegidas por uma cobertura vegetal de remanescentes da floresta atlântica, situação que atualmente não existe onde, os constantes recortes de taludes expõem material friável e de fácil deterioração pela ação pluviométrica.

As regiões mais densamente povoadas, encontram-se principalmente nos setores sudoeste na divisa com o município de Embu, onde nos últimos 20 anos a ocupação desordenada avançou sobremaneira sendo criados bairros como: Vila Indiana, São Judas, Jardim Salete etc. 
$\mathrm{Na}$ região sudeste do município localizam-se as áreas mais problemáticas com relação à ocupação e às características físicas pois, ai localiza-se a área de várzea onde corre a maior porção do córrego Pirajussara, separando o município de partes da zona sul da cidade de São Paulo (Campo Limpo). As curvas de nível nesta parte encontram-se de acordo com o mapa acima distanciadas, evidenciando o trabalho morfológico da construção de várzeas, realizado pelo Córrego durante milhares de anos e que hoje a mesma área encontra-se totalmente modificada.

Tais modificações, de característica antropogênica apresenta os seguintes resultados:

- Canalização total do Córrego, tendo como finalidade a construção de novas vias;

- Criação de áreas de escape das águas fluviais do referido córrego (Piscinão), que tinha o intuito de evitar alagamentos, o que atualmente tornou-se impossível em virtude dos altos índices pluviométricos e do constante entulhamento do Córrego e conseqüentemente do referido piscinão; 
- Em virtude de ser uma área mais plana (vide mapa de curvas de nível - Figura 38), com a canalização e cobertura do Córrego, permitiu-se o avanço gradual das construções sobre a antiga área de vazante do mesmo.

Estes aspectos permite-nos afirmar que existe uma política de uso do solo equivocada não só neste município, como em outros da mesma região, tanto no erro de se ocupar áreas impróprias para moradias e comércio, como também no fato de se optar por métodos de intervenção urbana que não concorrem para a resolução dos problemas oriundos da compactação do assoalho urbano, tendo como principal conseqüência a modificação dos regimes pluviais, e de escoamento de suas águas. 


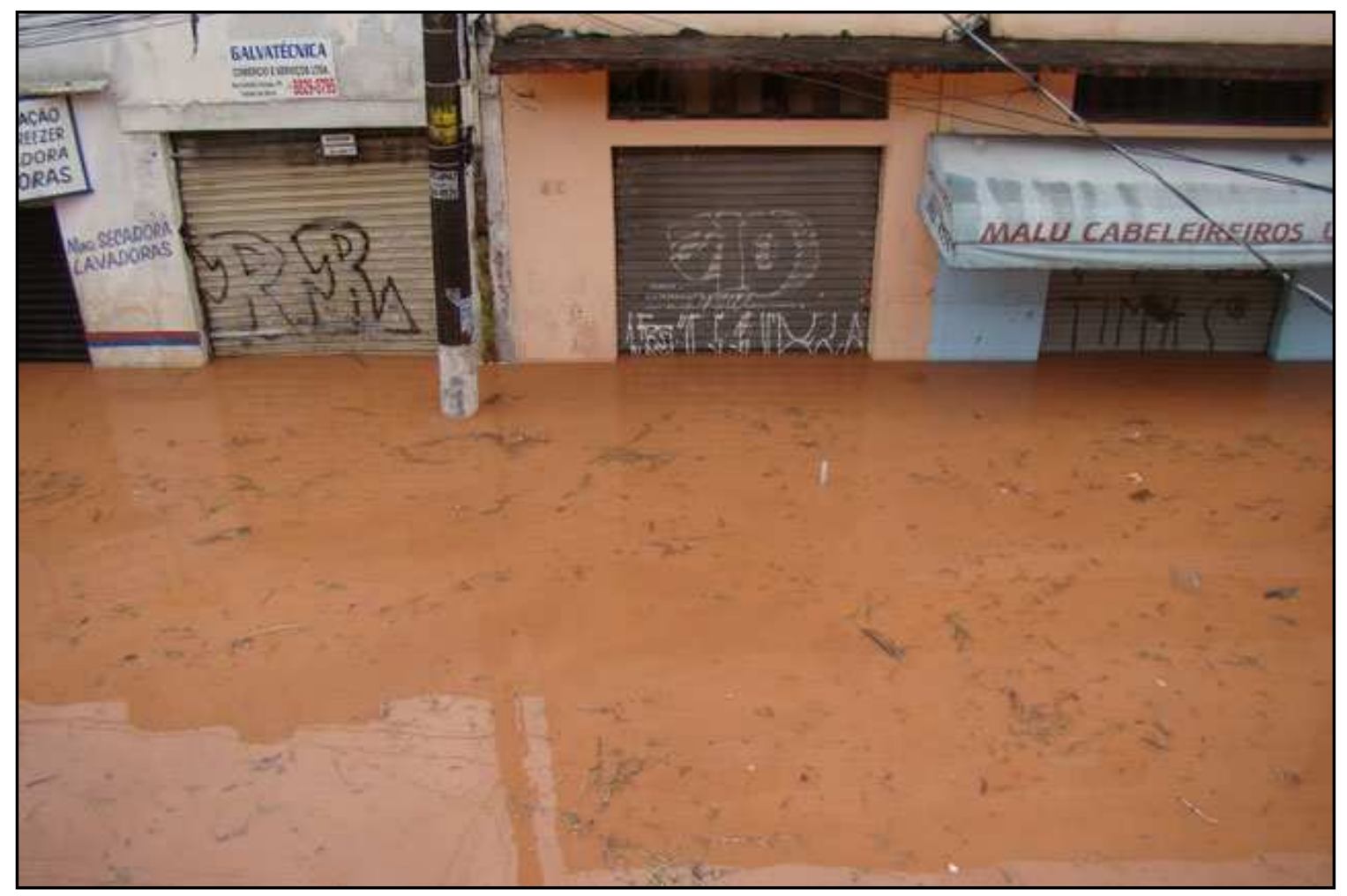

Foto 34 - Centro de Taboão da Serra - Episódio de inundação em 01/12/2009. Rua próxima ao piscinão. Observa-se a concentração de lixo e os prejuízos materiais de uma política de uso do solo eauivocada.

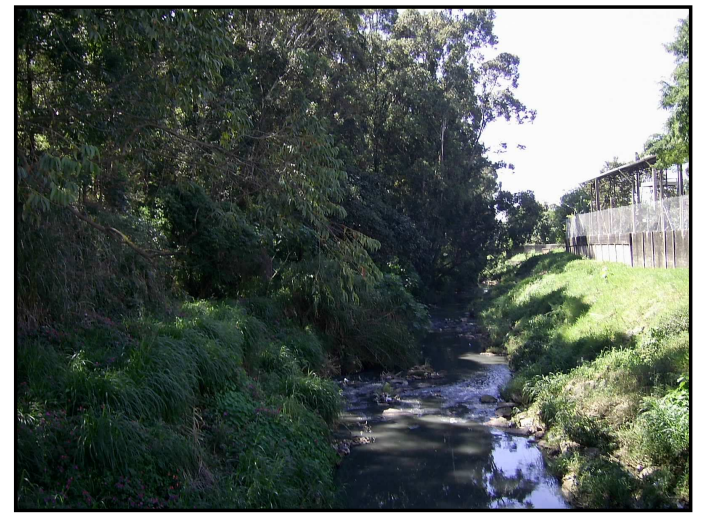

Foto 35 - Entalhamento do Córrego Poá.

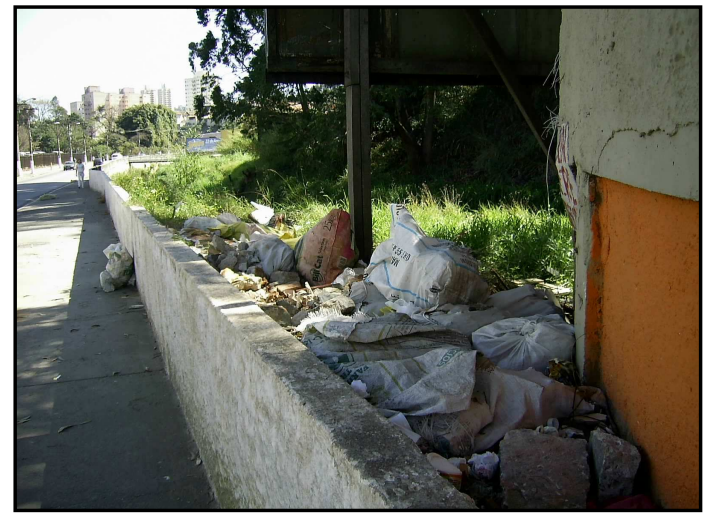

Foto 36 - Degradação ambiental do córrego João cachoeira lixo às suas margens. 


\subsection{CARTA DE USO DA TERRA (1962)}

As ortofotos que compõem a base cartográfica digital de uso da terra para 1962, serviram como parâmetro para a interpretação das fotos aéreas do uso e ocupação levando-se em consideração as características visuais representativas.

\subsubsection{Características técnicas}

Esta base compreende toda a área dos limites administrativos do município de Taboão da Serra/SP, somando aproximadamente $20,38 \mathrm{Km}^{2}$.

Como produto de trabalho em software de geoprocessamento, a base foi inserida e trabalhada em arquivos do tipo MXD. Estes arquivos contém toda a configuração necessária como cores, escala, organização dos dados (layers) etc.

Esta base, assim como as fotos aéreas estão georreferenciadas na projeção UTM (Universal Transversa de Mercator) e o datum de base é o south American Datum 1969 (SAD69), com fuso de 23 S. A base cartográfica foi elaborada a partir da fotointerpretação das aerofotografias que datam de 1962. Iniciamos pelo processo de digitalização e georreferenciamento, entretanto as fotos não foram ortorretificadas, gerando com isto, deslocamentos nas bordas das aerofotos, tal fato se dá, devido à distorção radial das mesmas.

Como referência para o georreferenciamento utilizou-se os logradouros e as imagens recentes de 2007 para não incorrermos em erros grosseiros quando iniciado o processo de união do mosaico.

Características tais como, escala original de 1:25.000, necessidade do processo de digitalização, contribuíram na redução da qualidade das fotos aéreas, fato este que limitou a 
interpretação, tendo como resultado a demarcação apenas de poucas classes que estão descritas abaixo: 


\begin{tabular}{|c|c|}
\hline \multicolumn{2}{|r|}{$\begin{array}{c}\text { Tab.12- Base Cartográfica e Uso da Terra/1962 e } 2007 \text { - Taboão da Serra/SP - } \\
\text { CLASSIFICAÇÃO/FUNÇÕES }\end{array}$} \\
\hline MATA & $\begin{array}{l}\text { "Vegetação constituída por árvores de porte superior a } 5 \text { metros, cujas copas se toquem (no tipo mais } \\
\text { denso) ou que propiciem uma uma cobertura de pelo menos } 40 \% \text { (nos tipos mais abertos)" (UNESCO, } \\
1973 \text { ). No caso de formações secundárias, não completamente evoluídas, o porte das árvores pode ser } \\
\text { inferior a } 5 \text { metros, tendo, porém, esses elementos apenas um tronco (são árvores e não arbustos); }\end{array}$ \\
\hline CAPOEIRA & $\begin{array}{l}\text { "Vegetação secundária que sucede à derrubada das florestas, constituída principalmente por indivíduos } \\
\text { lenhosos de segundo crescimento, na maioria, da floresta anterior e por espécies espontâneas que } \\
\text { invadem as áreas devastadas, apresentando porte desde arbustivo até arbóreo, porém com árvores } \\
\text { finas e compactamente dispostas" (SERRA Fo ET AL, 1975); }\end{array}$ \\
\hline CAMPO & $\begin{array}{l}\text { Vegetação caracterizada, principalmente, pela presença de gramíneas, cuja altura, geralmente varia de } \\
10 \text { a } 15 \text { centímetros aproximadamente, constituindo uma cobertura que pode ser quase contínua ou } \\
\text { apresentar-se sob a forma de tufos deixando, nesse caso, alguns trechos de solo a descoberto. } \\
\text { Espaçadamente poderão ocorrer pequenos substratos e, raramente, arbustos. (ROMARIZ, 1974); }\end{array}$ \\
\hline SOLO EXPOSTO & $\begin{array}{l}\text { Solo preparado para cultivo e áreas que se encontram sem cobertura vegetal, devido à ação dos } \\
\text { processos erosivos. }\end{array}$ \\
\hline $\begin{array}{l}\text { ÁREA } \\
\text { URBANIZADA }\end{array}$ & $\begin{array}{l}\text { Constituída por áreas arruadas e efetivamente ocupadas por uso residencial, comercial ou de serviços, } \\
\text { caracterizada pela presença de ruas, casas e prédios. Foram mapeadas como áreas urbanizadas as } \\
\text { quadras e partes de quadras vagas e condomínios de prédios em construção, garagem de ônibus, } \\
\text { supermercados, postos de gasolina, shopping centers; }\end{array}$ \\
\hline CHÁCARA & $\begin{array}{l}\text { Foram mapeadas como chácaras os loteamentos de chácaras de lazer ou de uso residencial e as sedes } \\
\text { de sítios que se encontram sobretudo ao longo das estradas vicinais. Formam um conjunto de } \\
\text { propriedades menores, com certa regularidade no terreno e são identificadas pela presença de }\end{array}$ \\
\hline
\end{tabular}




\begin{tabular}{|l|l|}
\hline & pomares, hortas, solo preparado para plantio, lagoas, bosques, quadras de esportes, piscinas, etc. \\
\hline LOTEAMENTO & $\begin{array}{l}\text { Áreas arruadas com até 10\% de ocupação, podendo estar localizados, dentro da área urbanizada, na } \\
\text { periferia ou isoladas. É caracterizado necessariamente por um conjunto de arruamento, podendo ser } \\
\text { geométrico ou irregular, sobre solo com ou sem cobertura vegetal; }\end{array}$ \\
\hline
\end{tabular}

Elaboração: Araujo, W. 2009. 


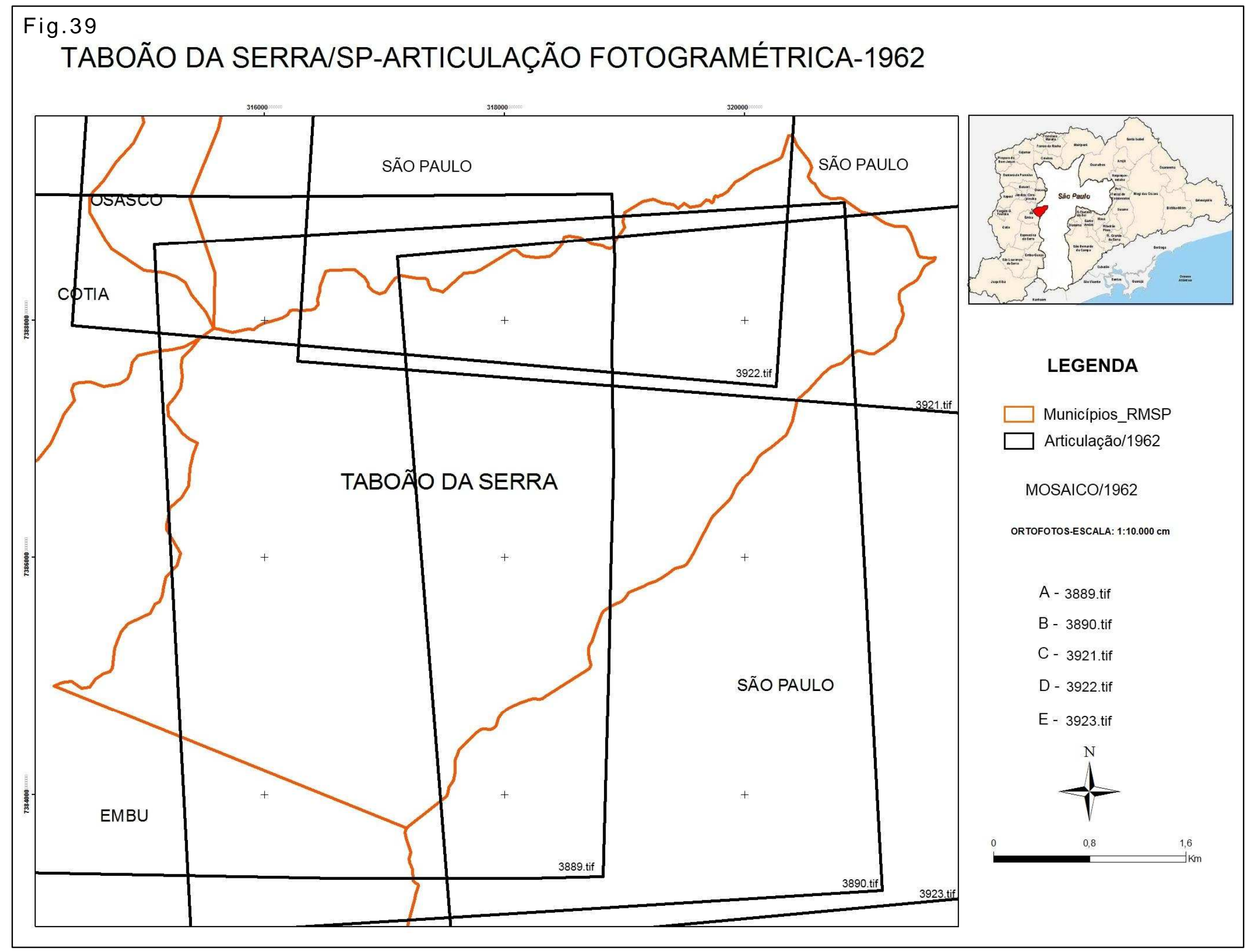


Fig.40 TABOÃO DA SERRA/SP - ORTOFOTO/MOSAICO/1962
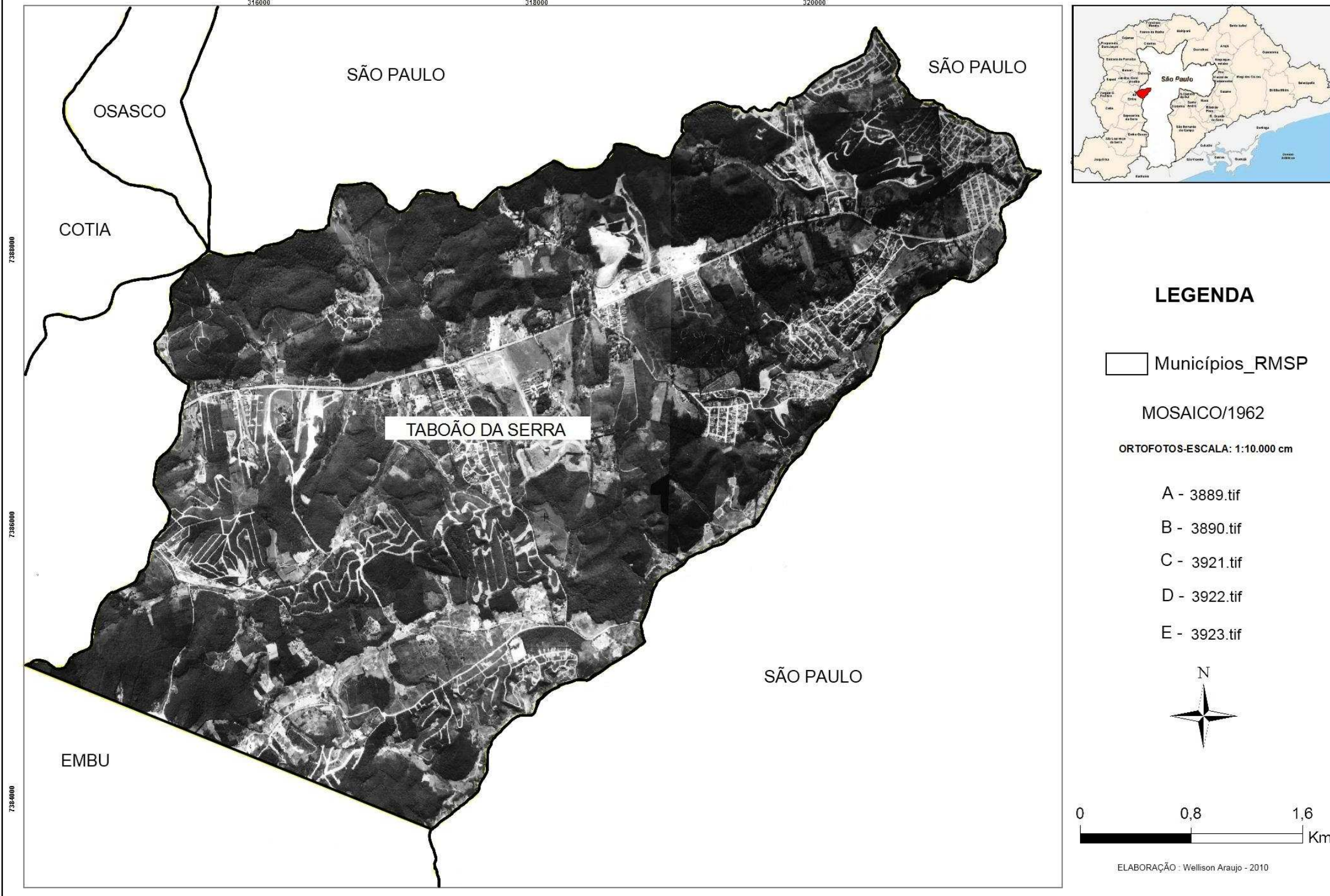

\section{LEGENDA}

Municípios_RMSP MOSAICO/1962 ORTOFOTOS-ESCALA: $1: 10.000 \mathrm{~cm}$

A - 3889.tif

B - 3890.tif

C - 3921. tif

D - 3922.tif

$\mathrm{E}-$ 3923.tif
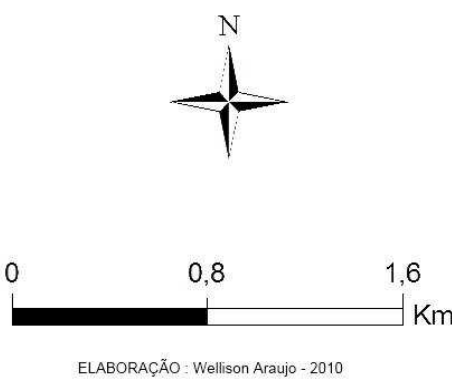


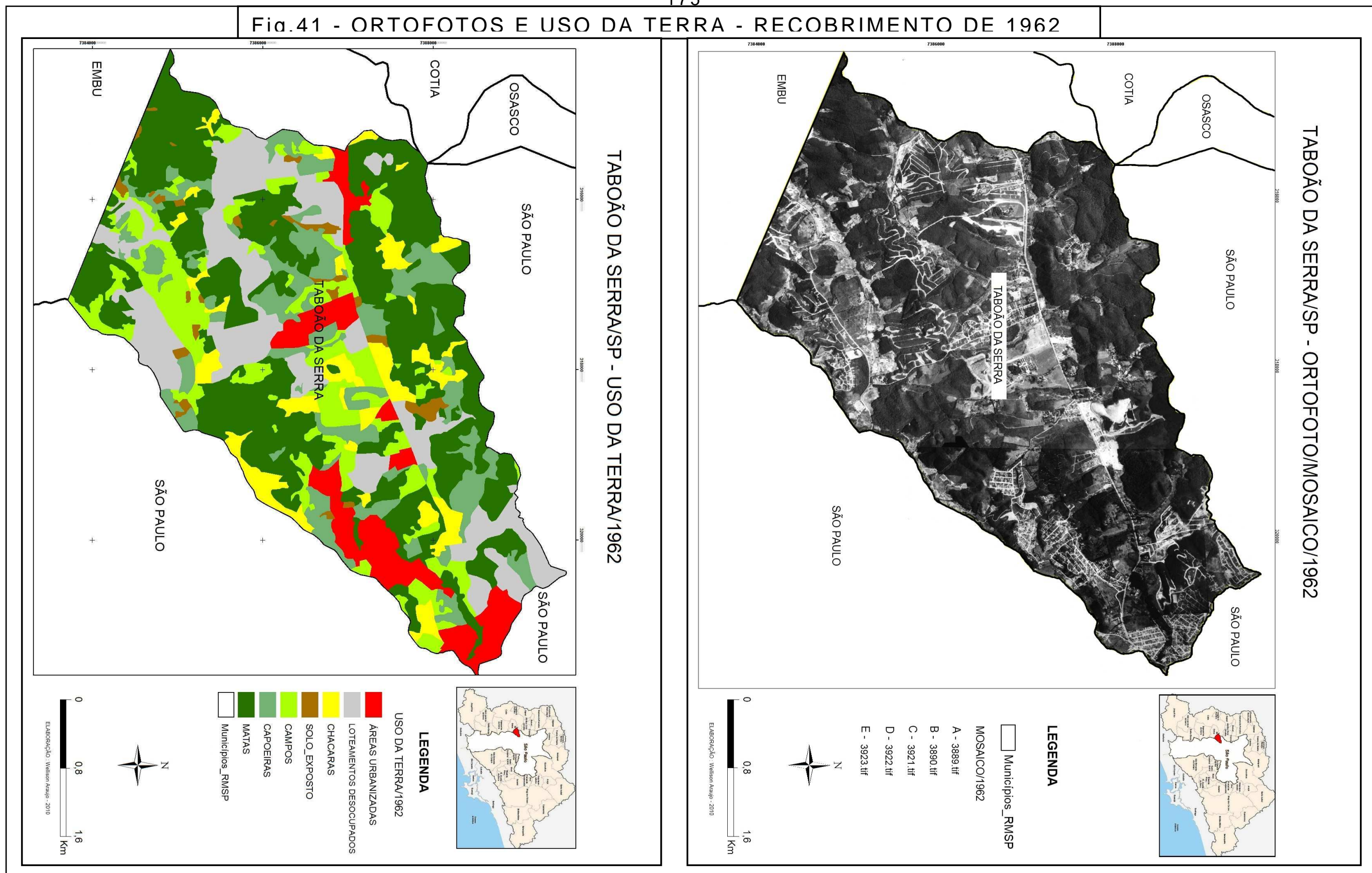


Fig.42 TABOÃO DA SERRA/SP - USO DA TERRA/1962
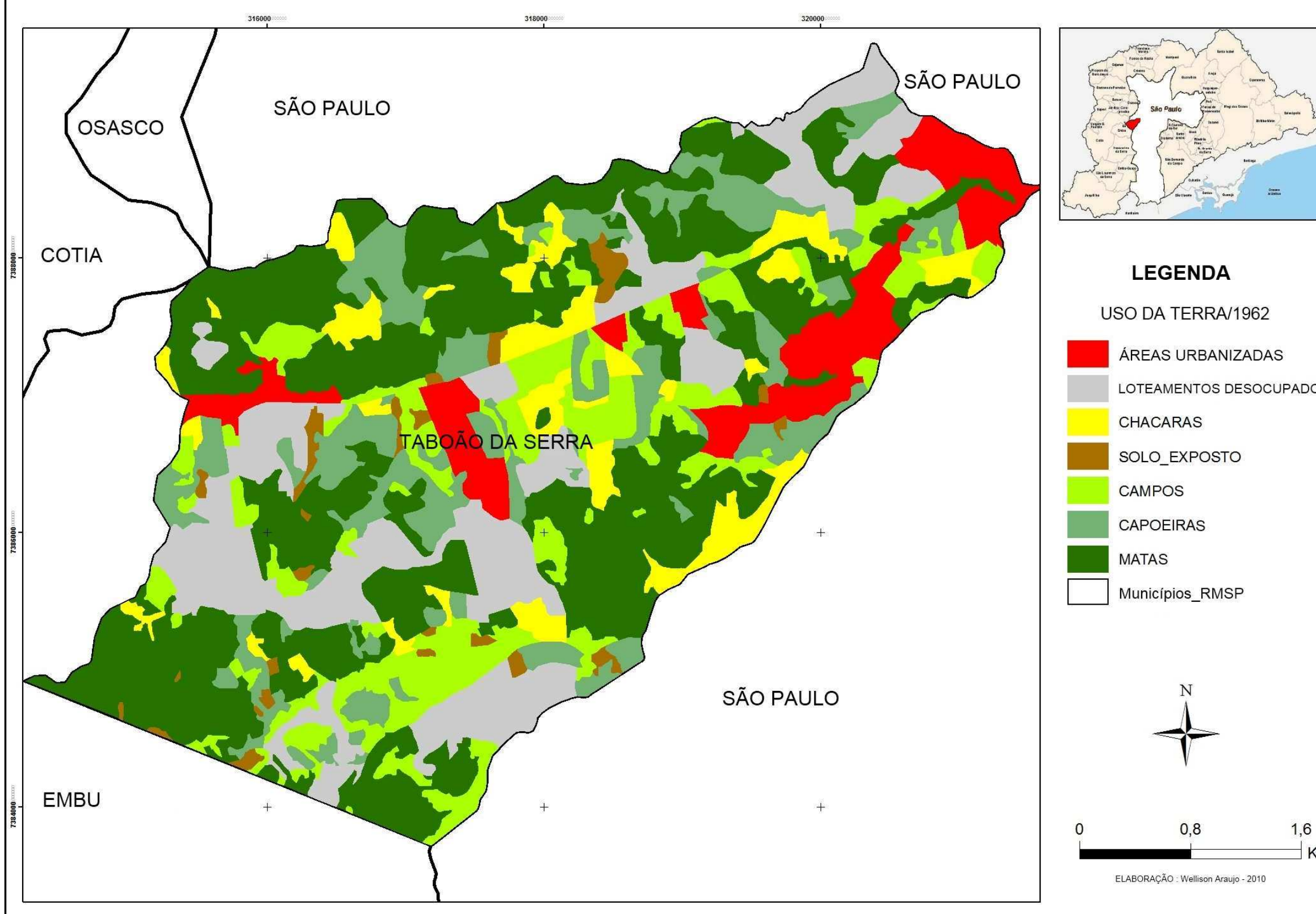

\section{LEGENDA}

USO DA TERRA/1962

ÁREAS URBANIZADAS

LOTEAMENTOS DESOCUPADOS

CHACARAS

SOLO_EXPOSTO

CAMPOS

CAPOEIRAS

MATAS

Municípios_RMSP
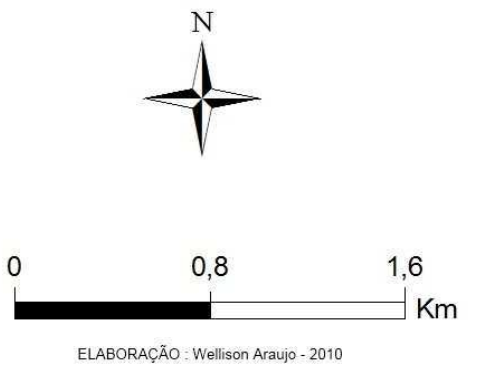
Tendo como base a carta síntese de Uso da Terra para o ano de 1962 (Fig. 42), verifica-se a concentração das poucas áreas urbanizadas ao longo da na época recém-inaugurada (1961), Rodovia Federal Régis Bittencourt ou SP-230, que é na verdade o prolongamento da BR-116 no seu trecho sul.

O município de Taboão da Serra, que poucos anos antes havia se desmembrado de Itapecerica da Serra, concentrava na maioria do seu território, chácaras de variadas extensões, pois, servia como local de veraneio para muitas famílias da capital paulista.

Com relação aos percentuais de uso e ocupação do território do município em 1962 (Tabela 12), verifica-se que para a área classificada como "área urbanizada" corresponde a $1,71 \mathrm{~km}^{2}$, ou seja, aproximadamente $8,38 \%$ da área total do município. Esta urbanização correspondia à presença de algumas residências e um incipiente comércio que ainda dependia de Itapecerica e também do fluxo de mercadorias provenientes da capital.

A evolução do uso da terra a partir de 1962, provocou, principalmente nas áreas com declives acentuados, assim como nas áreas adjacentes aos córregos locais um adensamento excessivo. Tal fato, é corroborado principalmente pelos episódios de cheias do Córrego Pirajussara, os quais ocorrem no ápice do verão, mesmo com a construção de modelos importados (piscinões) que funcionam como medidas paliativas.

De acordo com a legenda explicativa, pode-se inferir algumas considerações acerca da carta de Uso da Terra para o ano de 1962:

- A área urbanizada em vermelho, mostra-se mais próxima espacialmente e economicamente totalmente dependente da capital, a área é na verdade uma continuação de São Paulo referente aos bairros Butantã e Campo Limpo; 
- Os loteamentos desocupados são na verdade, grandes extensões de terras de domínios públicos e privados, a insipiente rede de estradas, são na verdade estradas vicinais sem pavimentação e que ainda não provocavam significativos impactos ao meio, embora já não apareça a mata original;

- As áreas classificadas como chácaras, em amarelo, apesar de numerosas, apresentam uma característica de preservação do meio físico;

- As áreas em marrom (solo exposto), ainda são insignificantes, correspondendo a aproximadamente $1,75 \%$ da área municipal;

- Pelas características das ortofotos, algumas apresentando baixa qualidade visual, classificamos como "campo" aquelas áreas onde não há uma distinção entre estes e os hortigranjeiros, contudo, os impactos da falta da mata original ainda eram pouco expressivos;

- Os retângulos classificados como capoeira, foram assim chamados por mesclarem características de mata e campos.

As fotografias aéreas de 1962 nos mostra uma ocupação urbana inicial, levando-nos à concluir que a cidade se caracterizava por um núcleo urbano com função de cidade dormitório. A presença em maior proporção de áreas de matas, corresponde à uma época que a atividade industrial, e a urbanização ainda estavam sendo gestadas na futura RMSP. 


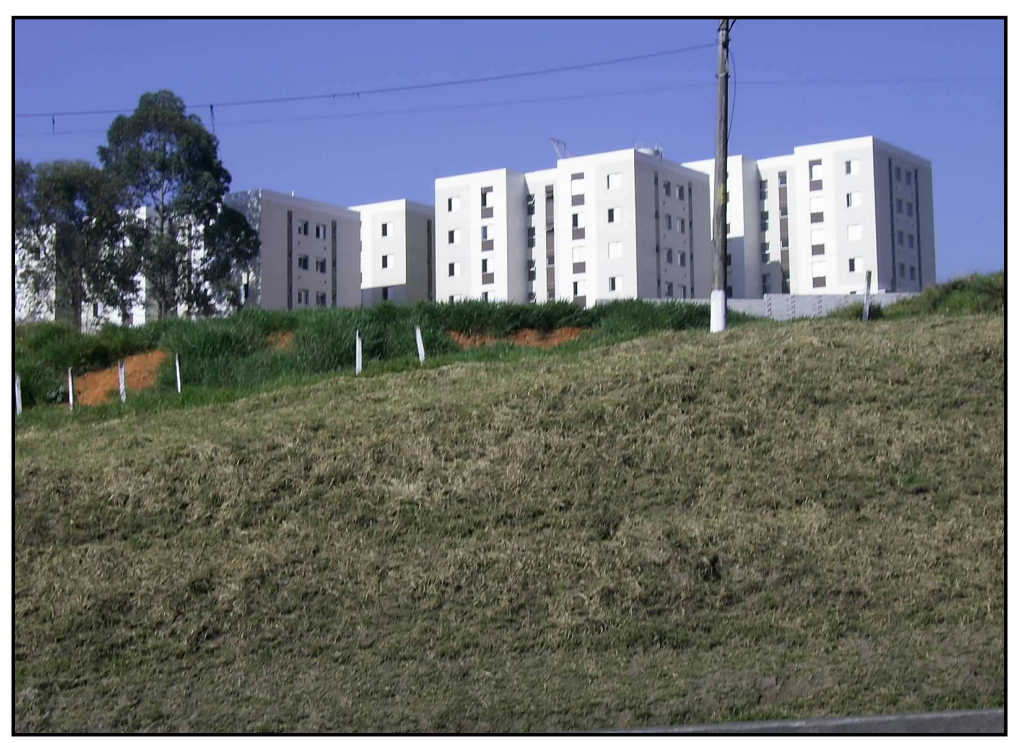

Foto 37 - Desmatamento e ocupação atual de 7onas ínaremes.

As áreas ocupadas de acordo com as fotografias aéreas de 1962, assentavam-se na várzea do córrego Pirajussara e também ao longo da rodovia. As condições ambientais vigentes mantinham equilíbrio pois, as áreas com cobertura vegetal perfazem mais da metade do território.

Com relação à ocupação ou uso do solo, a mesma encontravase circunscrita às áreas mais planas e menos íngremes, principalmente na divisa entre Taboão e São Paulo a nordeste do município.

A preservação das áreas mais íngremes do município e da cobertura vegetal original, propiciou a manutenção do equilíbrio dinâmico, fator positivo também para o escoamento superficial assim como para o fluxo dos córregos locais. 
Tabela 13 -Totais em porcentagem de ocupação de Uso da Terra - Taboão da Serra/SP 1962.

\begin{tabular}{|c|c|c|}
\hline Tipo de Uso & Área km² & $\begin{array}{c}\text { \% em relação a área } \\
\text { do município }\end{array}$ \\
\hline AREA_URBANIZADA & 1,71 & 8,38 \\
\hline CAMPO & 2,77 & 13,57 \\
\hline CAPOEIRA & 2,83 & 13,89 \\
\hline CHACARA & 1,45 & 7,14 \\
\hline LOTEAMENTO_DESOCUPADO & 3,55 & 17,44 \\
\hline MATA & 7,71 & 37,82 \\
\hline SOLO_EXPOSTO & 0,36 & 1,75 \\
\hline TOTAL MUNICÍPIO & 20,37 & 100,00 \\
\hline
\end{tabular}

\begin{tabular}{|l|r|r|}
\hline \multicolumn{1}{|c|}{ Ocupação } & Área km² & $\begin{array}{c}\text { \% em relação a área } \\
\text { do município }\end{array}$ \\
\hline Área Construída ${ }^{1}$ & 1,71 & 8,38 \\
\hline Área Não Construída ou Pouco Construída ${ }^{2}$ & 18,67 & 91,62 \\
\hline \multicolumn{2}{|c|}{} \\
\hline TOTAL MUNICÍPIO & $\mathbf{2 0 , 3 7}$ & $\mathbf{1 0 0 , 0 0}$ \\
\hline
\end{tabular}

\footnotetext{
1 - AREA_URBANIZADA

2 - CAMPO, CAPOEIRA, CHACARA, LOTEAMENTO_DESOCUPADO,MATA
} 


\subsection{CARTA DE USO DA TERRA (2007)}

Tendo como base as aerofotografias e apoiadas na base cartográfica de 2007, construiu-se a carta de Uso da Terra acima. As fotografias foram digitalizadas e georreferenciadas, fazendo-se as correções necessárias para a escala de análise.

\subsubsection{Características técnicas}

As bases foram georreferenciadas na projeção UTM (Universal Transversa de Mercator), e datum South American Datum 1969 (SAD69), fuso 23S, foi adicionada uma base cartográfica de logradouros do município de Taboão da Serra, obtida gratuitamente no INCT (Centro de Estudos da Metrópole).

A interpretação foi realizada manualmente não sendo necessário aplicar nenhuma técnica automatizada. Tal característica delega maior liberdade ao profissional para realizar as inferências necessárias de acordo com o objetivo da pesquisa.

A escala da carta foi fixada em 1:3.000 e a interpretação visual foi realizada de acordo com os critérios definidos pela EMPLASA apoiados nas cartas pré-existentes para a RMSP datada de 2002. De acordo com esses critérios foram encontradas as seguintes feições na área que abrange o município de Taboão da Serra:

De acordo com a distribuição visual e tendo como base de apoio a interpretação manual, verifica-se para Taboão da Serra uma maior predominância da "Área Urbanizada", correspondendo a quase $60 \%$ de todas as feições, seguindo-se da feição "Indústria" aproximadamente 14\%, da feição "Campo" 6,5\% (notase entretanto que, esta feição ocupa áreas antropizadas, geralmente taludes refeitos e cobertos por gramíneas para evitar erosão nas encostas da rodovia e dentro de áreas particulares de indústrias). A feição "Mata" com $6 \%$ (caracteriza-se 
principalmente pelo plantio de eucaliptos ou pinheiros para fins industriais).

As feições "Equipamento Urbano (Parques e Jardins), Favela,Loteamento Desocupado, Rodovia, Chácara e Solo Exposto", respondem por um montante expressivo quando combinado estas às feições de Área Urbanizada", ou seja, aproximadamente $10 \%$ de toda a área do município. 
Fig.43 TABOÃO DA SERRA/SP-RECORTE-ORTOFOTO/2007
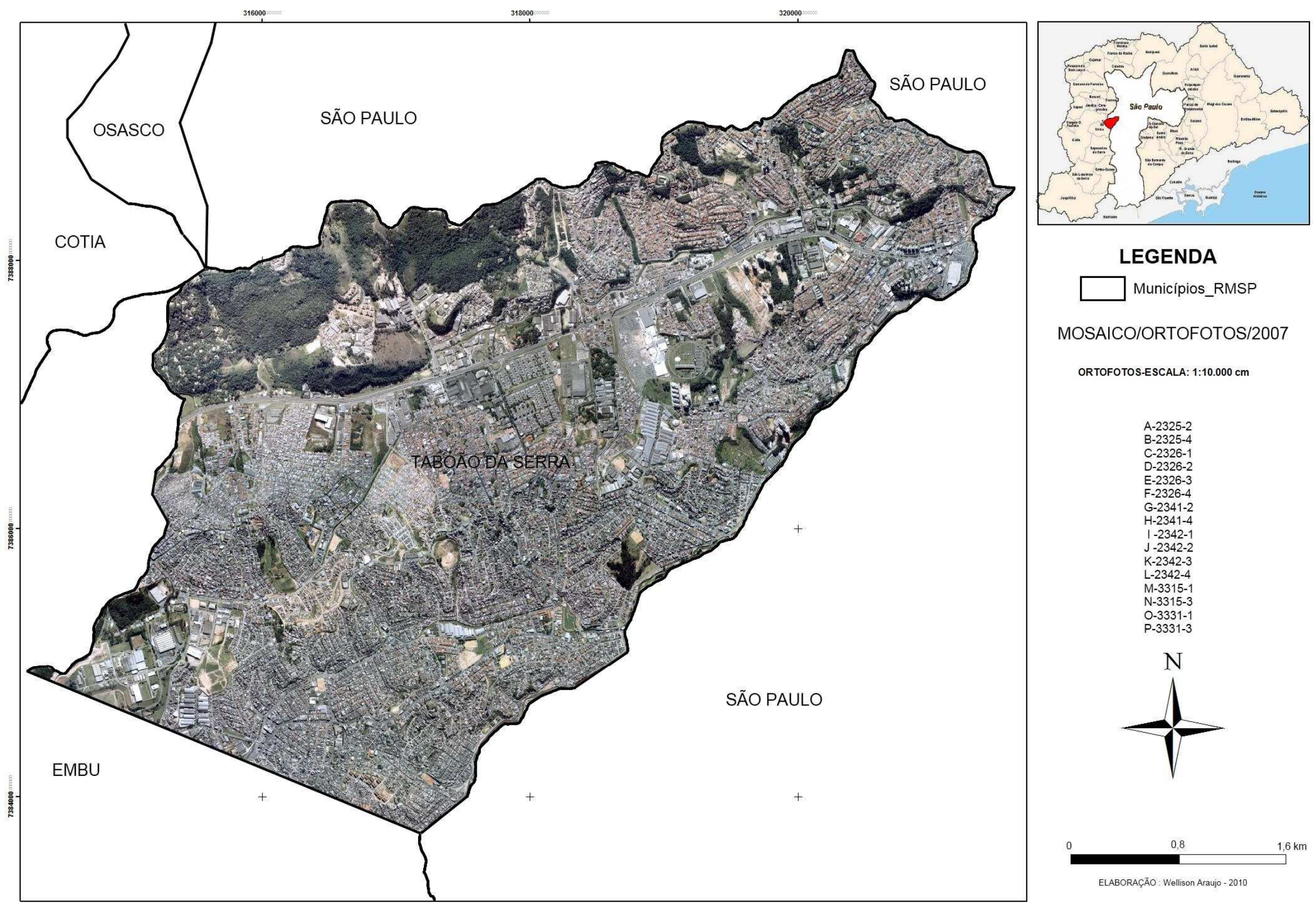

MOSAICO/ORTOFOTOS/2007

ORTOFOTOS-ESCALA: 1:10.000 cm

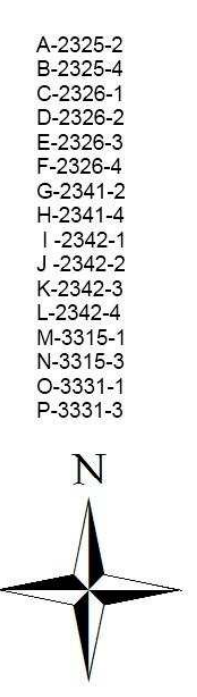




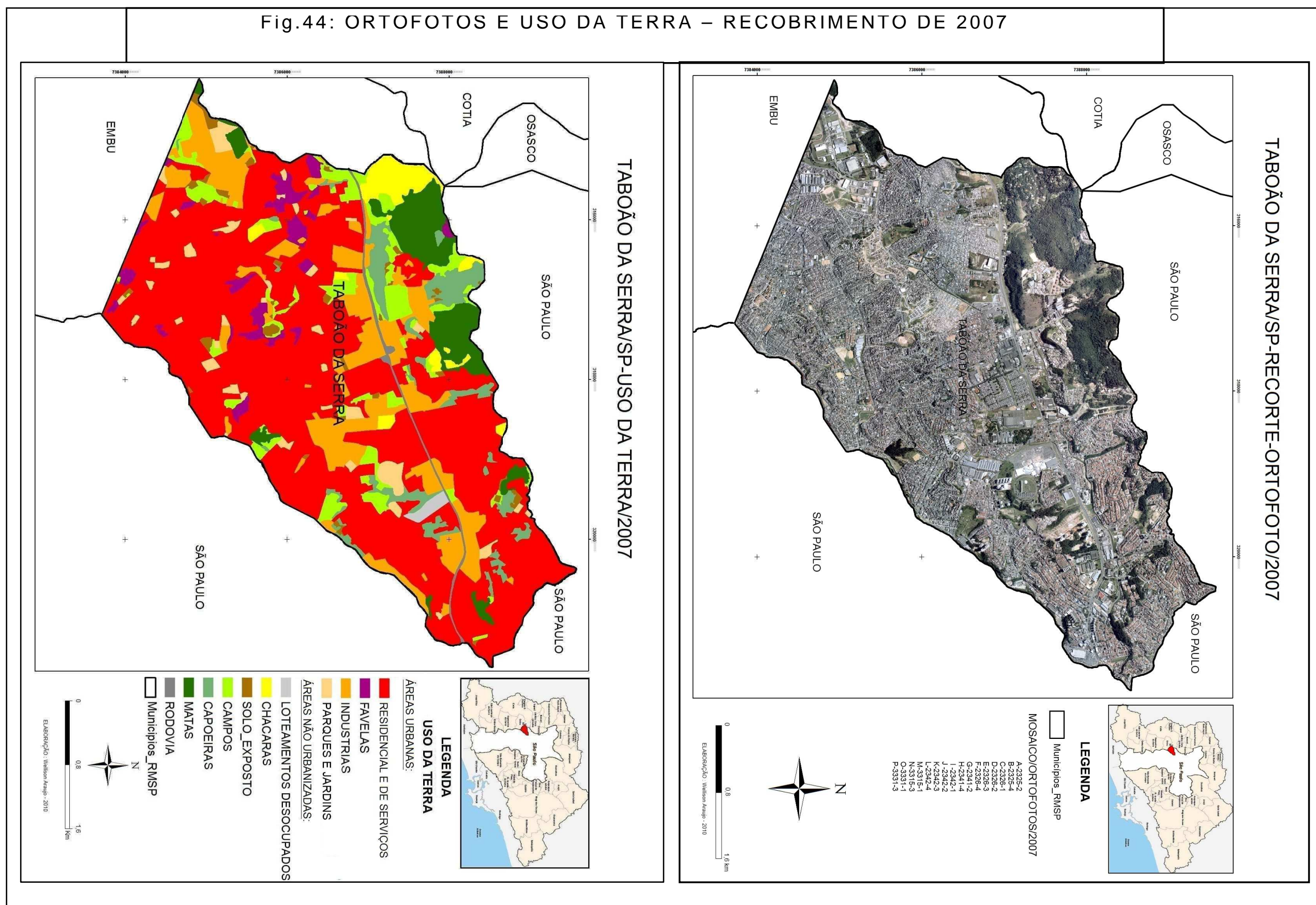


Fig.45 TABOÃO DA SERRA/SP-USO DA TERRA/2007

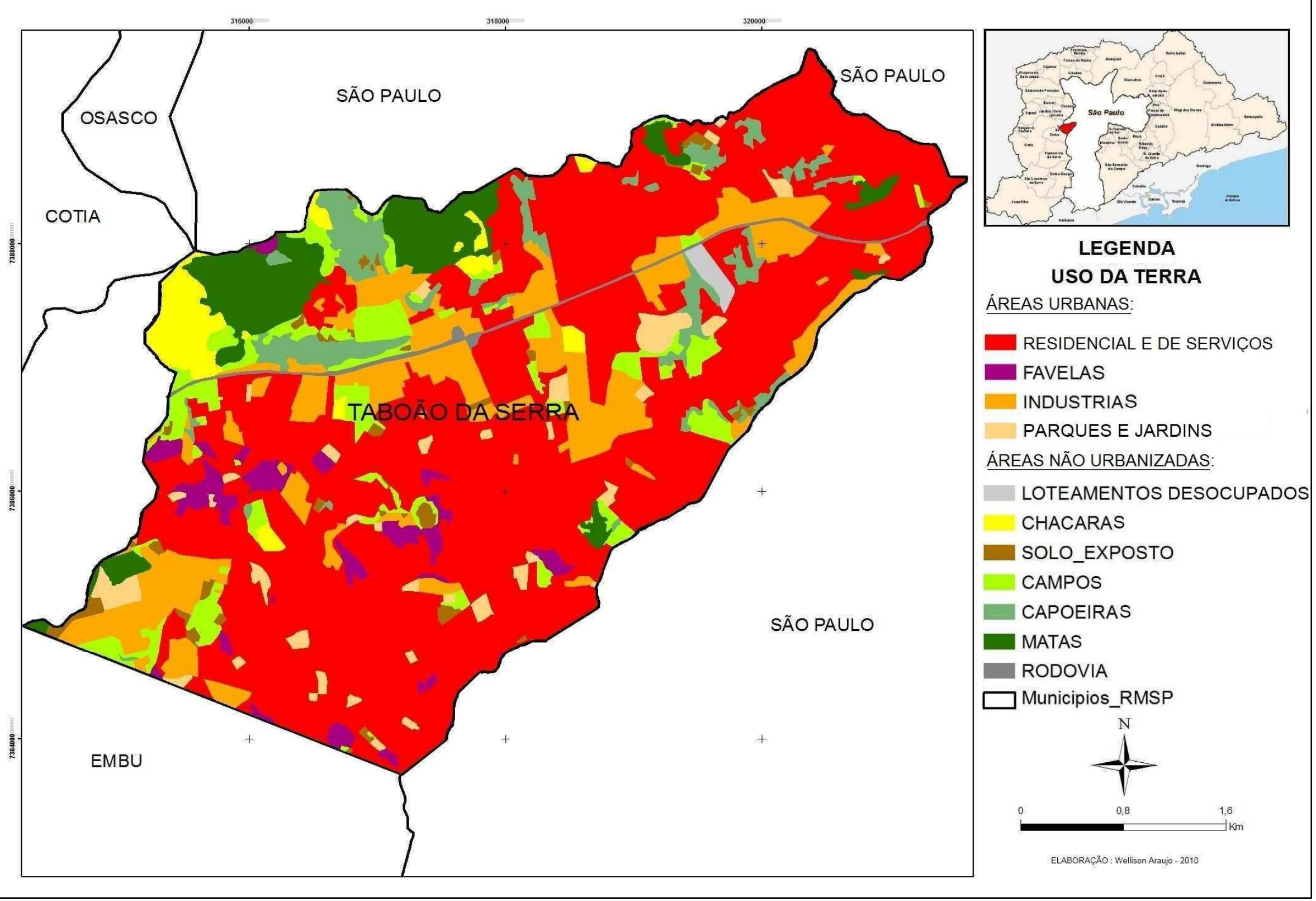


Tabela 14 -Totais em porcentagem de ocupação de

Uso da Terra - Taboão da Serra/SP 2007.

\begin{tabular}{|c|c|c|}
\hline Tipo de Uso & Área km² & $\begin{array}{c}\text { \% em relação a área } \\
\text { do município }\end{array}$ \\
\hline AREA_URBANIZADA/ EQUIPAMENTO_URBANO & 12,59 & 61,81 \\
\hline CAMPO & 1,27 & 6,22 \\
\hline CAPOEIRA & 0,96 & 4,71 \\
\hline CHACARA & 0,54 & 2,66 \\
\hline FAVELA & 0,56 & 2,73 \\
\hline INDUSTRIA & 2,71 & 13,32 \\
\hline LOTEAMENTO_DESOCUPADO & 0,08 & 0,39 \\
\hline MATA & 1,23 & 6,03 \\
\hline RODOVIA & 0,17 & 0,85 \\
\hline SOLO_EXPOSTO & 0,26 & 1,29 \\
\hline TOTAL MUNICÍPIO & 20,38 & 100,00 \\
\hline Ocupação & Área km² & $\begin{array}{c}\text { \% em relação a área } \\
\text { do município }\end{array}$ \\
\hline Área Construída ${ }^{1}$ & 16,04 & 78,71 \\
\hline Área Não Construída ou Pouco Construída ${ }^{2}$ & 4,34 & 21,29 \\
\hline TOTAL MUNICÍPIO & 20,38 & 100,00 \\
\hline
\end{tabular}

AREA_URBANIZADA, EQUIPAMENTO_URBANO, FAVELA, INDUSTRIA,RODOVIA

2 - CAMPO, CAPOEIRA, CHACARA, LOTEAMENTO_DESOCUPADO,MATA 
Os dados sócio-econômicos realizados através de pesquisas da Fundação SEADE e IBGE para o ano de 2000 apresentam com relação à ocupação e às condições de infra-estrutura das residências os seguintes resultados: 
Tabela 15 - Habitação e Infra-estrutura urbana/2000

\begin{tabular}{|l|c|c|}
\hline \multicolumn{1}{|c|}{ Habitação e Infra-estrutura Urbana } & Ano & Município \\
\hline Domicílios com espaço suficiente em (\%) & 2000 & 74,50 \\
\hline Domicílios com infra-estrutura interna adequada em (\%) & 2000 & 83,16 \\
\hline Coleta de Lixo - Nível de atendimento em (\%) & 2000 & 99,37 \\
\hline Abastecimento de água - Nível de atendimento em (\%) & 2000 & 98,41 \\
\hline Esgoto Sanitário - Nível de atendimento em (\%) & 2000 & 98,37 \\
\hline
\end{tabular}

OBS: De acordo com os dados de pesquisa das "Condições de Vida" da população do município, o mesmo no ano de 2004 foi classificado como sendo do Grupo 2 (Municípios que, embora com níveis de riqueza elevados, não exibem bons indicadores sociais). O mesmo ocorreu para os dados de 2006 (Fundação SEADE/2007). Mesmo assim, o município apresenta índices acima em comparação com as médias do Estado, principalmente na coleta de lixo $(99,41 \%)$ e no abastecimento de água $(98,37 \%)$. 
Há de se considerar que o fator "Domicílios com espaço suficiente" torna-se discutível e com margens a outras interpretações pois, não existe um padrão para o que se pode chamar de espaço suficiente para o bem-estar de moradia de uma família. Não está claro se o espaço suficiente levando em consideração na pesquisa diz respeito ao espaço interno ou externo.

\section{Fig.46 - Comparação da Infra-Estrutura Urbana/Domicílios com Espaço Suficiente-2000}

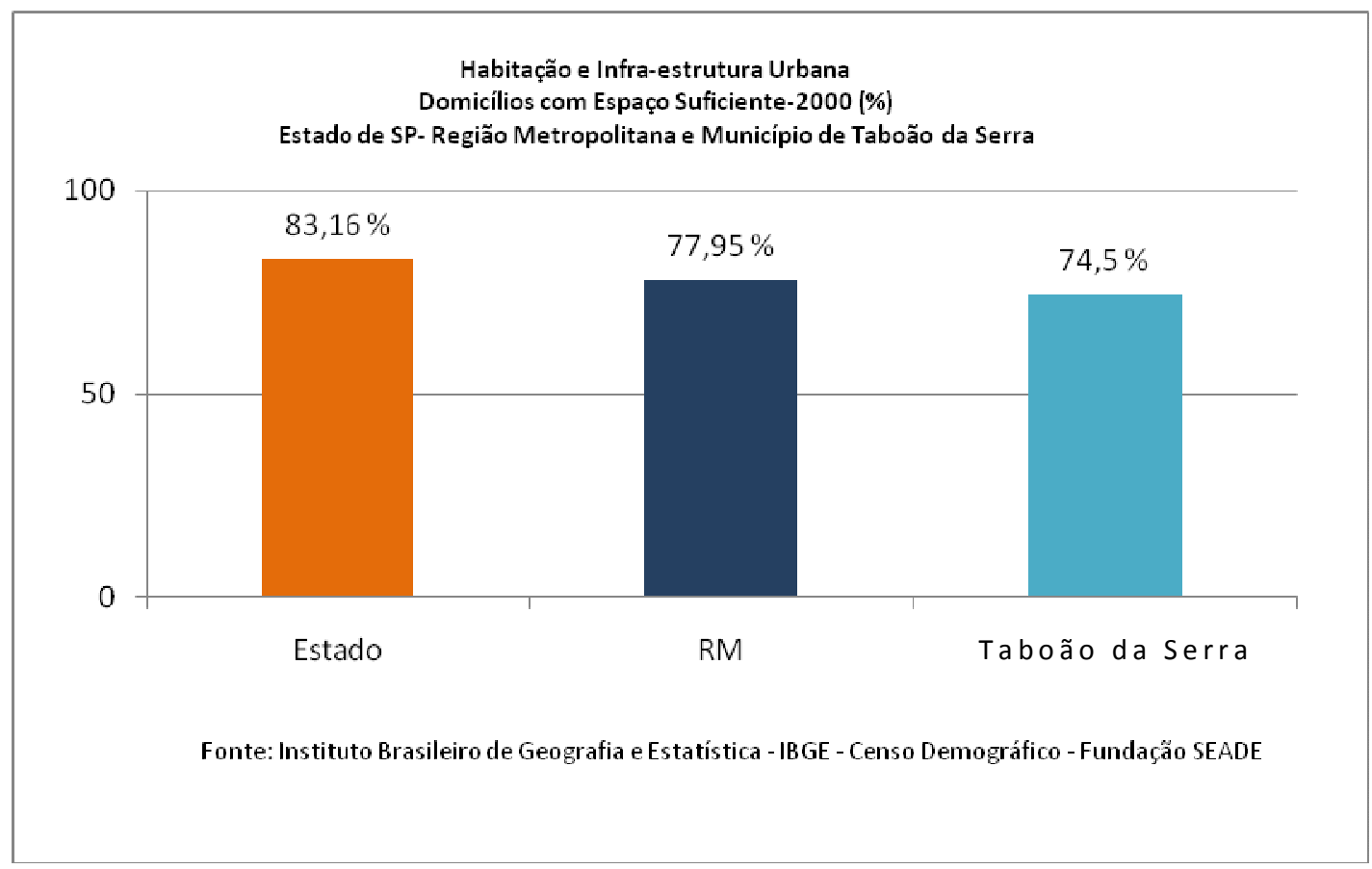

A figura acima representa uma característica marcante do município, que é o resultado da equação moradia versus número de ocupantes. Tal pesquisa não demonstra as características das moradias pois, pode-se ter espaço suficiente mas de forma desordenada.

A afirmação se apóia no exemplo de se ter em Taboão da Serra como método de construção os chamados "puxados", que nada mais são que uma verticalização sem uma engenharia 
adequada, sem fundação (vigas de sustentação), onde as casas recebem um segundo ou até terceiro pavimento adicionando peso excessivo ao térreo.

Tal problema é visualmente notado, principalmente nos bairros periféricos, onde as construções na sua parte exterior não recebem revestimento (reboco) provocando infiltração das águas da chuva resultado de técnicas de construção civil inadequada, provocando uma verticalização desordenada.

O gráfico acima portanto, demonstra o estado quantitativo dos domicílios, mas por outro lado mascara o estado qualitativo das mesmas.

De acordo com a evolução do Uso da Terra, e apoiado nas características da ocupação e uso do solo em Taboão da Serra na Carta de Uso de 2007 (Figura 45), podemos fazer algumas considerações tendo como base a legenda da classificação:

- Os mapas de uso do solo, elaborados a partir da cobertura aerofotogramétrica de 1962, em comparação com o realizado em 2007, demonstra a queda brusca em termos de porcentagem das áreas verdes da cidade.

- A área urbanizada (Tabela 13), como ficou evidente, corresponde espacialmente a aproximadamente $60 \%$ da cobertura do solo, nestas áreas há a ocorrência de construções de baixo, médio e alto padrão, esta feição, leva em consideração tanto a cobertura do solo pela implantação da cimentação e asfaltamento, quanto pela densificação das construções;

- A área denominada como campo, apresenta agora pequenas manchas em comparação com 1962, caindo sua concentração para menos da metade em 2007, de aproximadamente $14 \%$ para $6 \%$, os campos, podem ser in lócus também as áreas com cobertura de gramíneas, 
principalmente aquelas que estão localizadas nas encostas construídas para evitar o desmoronamento d e material sobre a rodovia d concorrer numa melhor percolação das águas pluviais;

- A área denominada como "capoeira" abrange aproximadamente $5 \%$ da área total do município, esta feição foi assim classificada por apresentar características entre "campo" e áreas de "solo exposto";

- Os retângulos em amarelo caracterizam os domínios das chácaras, elas abrangem $2,66 \%$ da área total do município, e se localizam na área de limite municipal entre Embu e Taboão da Serra (Sudoeste do município), região que manteve alguns focos de mata original;

- Os retângulos classificados como "equipamento urbano" na cor mostarda, referem-se às praças e aos objetos que são de uso público no município; 


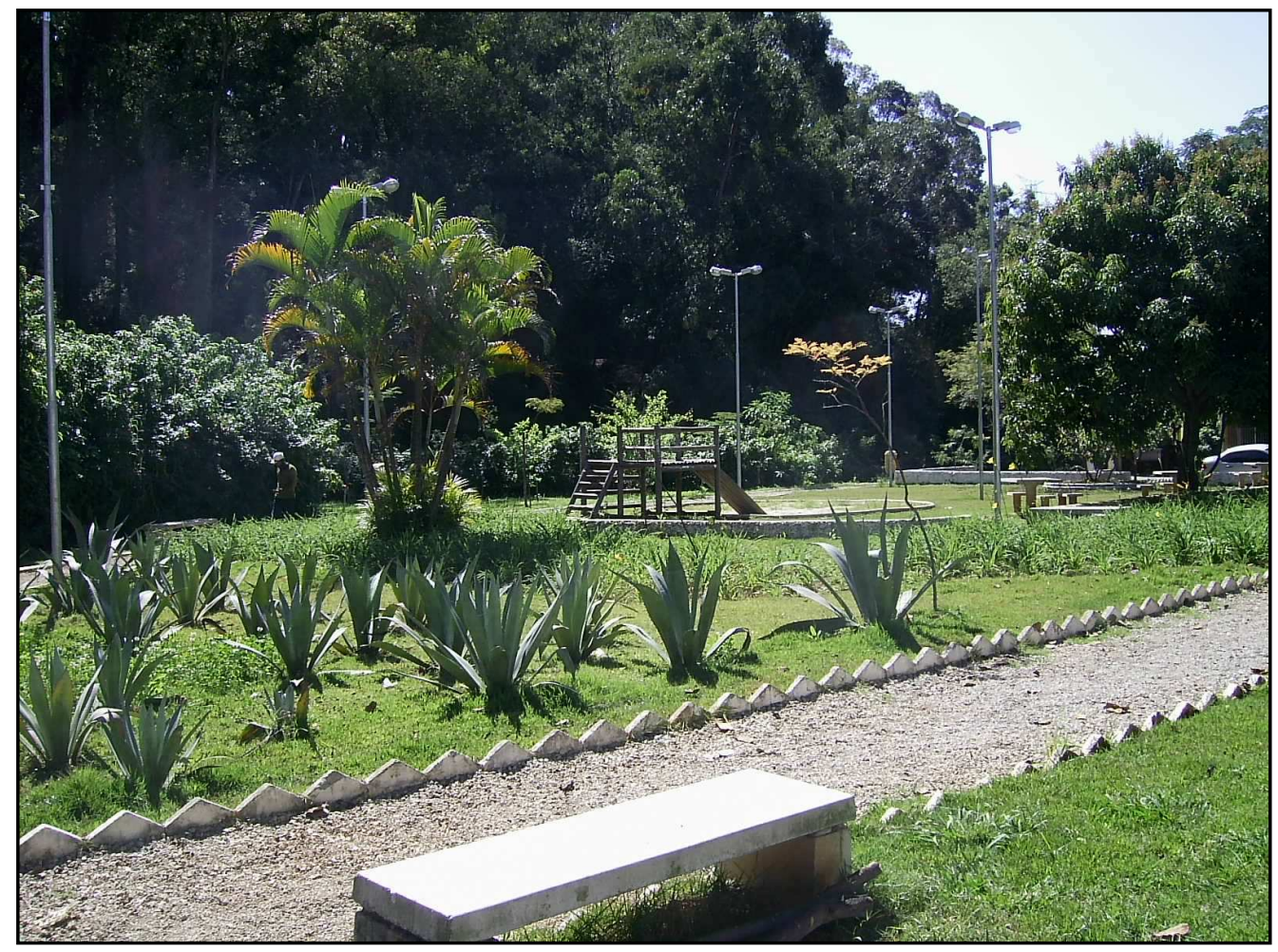

Foto 38 - Área classificada como equipamento urbano: Praça próximo ao centro do município, ao lado do córrego Poá.

- Os loteamentos desocupados, em cinza claro, são umas das feições mais raras nessa classificação, correspondem a aproximadamente $0,40 \%$ da área municipal e são feições em extinção na região pela alto adensamento das construções e da procura por áreas ainda disponíveis para a construção civil e particular;

- Os retângulos em roxo, representam a anomalia urbana provocada pela ocupação do solo de forma desordenada e pelo baixo poder aquisitivo de uma população mal remunerada. As favelas representam aproximadamente $3 \%$ da área municipal, ocupam as áreas mais íngremes e de insalubridade quando se refere ao atendimento público às necessidades de saneamento básico; 


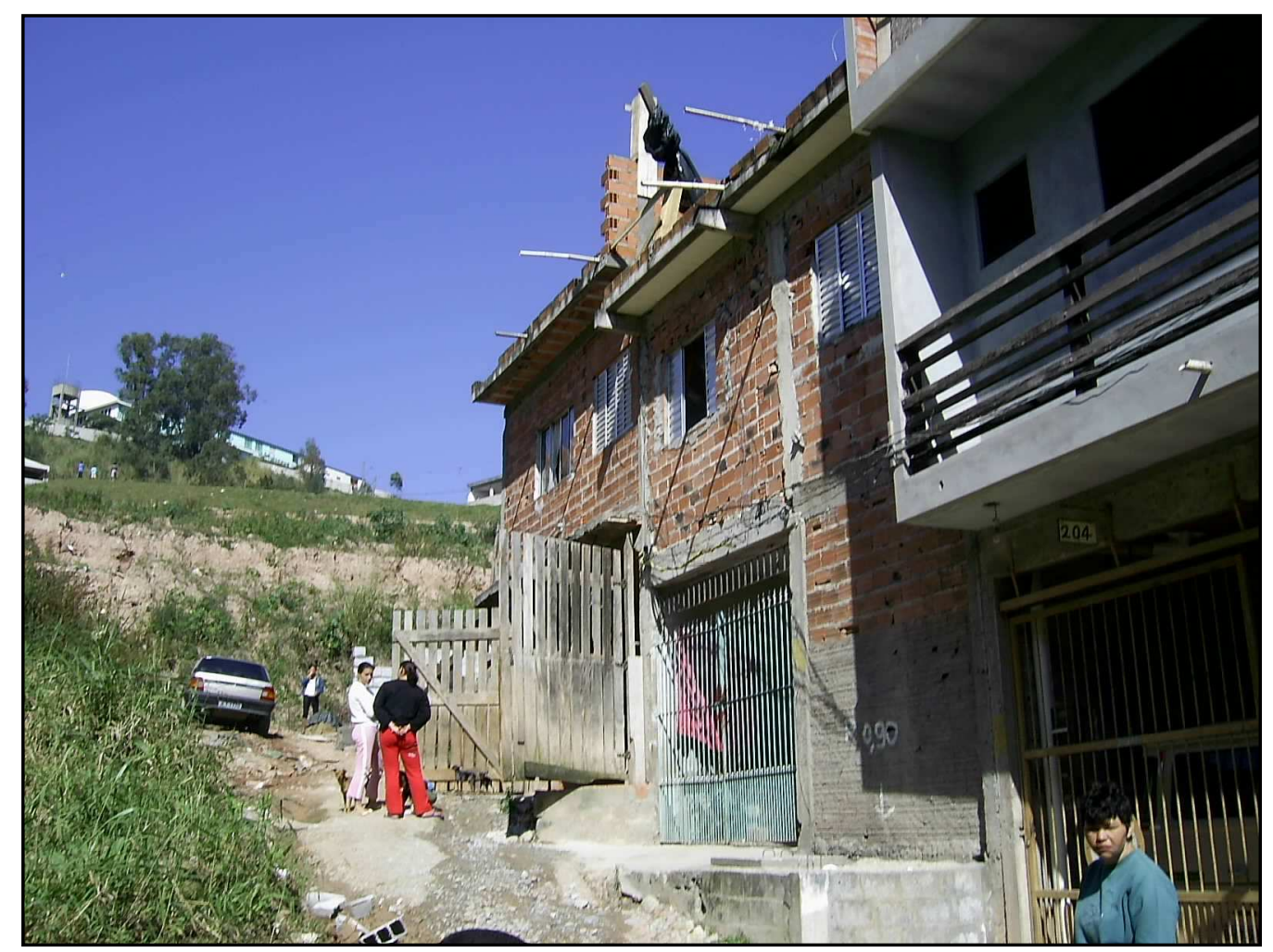

Foto 39 - Área de favelização, ocupação de loteamentos com retirada da cobertura vegetal de forma desordenada.

- A legenda destinada à representação das locações industriais (em cor laranja), espacialmente foi uma das que mais cresceram no município. Localizam-se próximas à rodovia, pois representa uma das vias de escoamento da produção e da facilidade de acesso. Esta classificação corresponde a aproximadamente $14 \%$ da área total; 
- A feição "solo exposto", representa uma das menores áreas na classificação. Com 1,29\% da área total, localiza-se na região sudoeste do município, principalmente na área limítrofe (Taboão/Embu);

- Finalmente, a área denominada "mata" é a que mais representa a transformação espacial nas características do uso da terra no município de Taboão da Serra. Em 1962 , esta área correspondia a aproximadamente $38 \%$ do total do município. Atualmente, esta mesma feição caiu para $6 \%$ do total. As conseqüências, a curto prazo foram a somatização dos problemas ambientais urbanos como: Elevação das médias térmicas intra-urbanas, dificuldade de percolação das águas pluviais, aumento das ocorrências de cheias dos piscinões e transbordamentos dos córregos Pirajussara e Poá etc. 


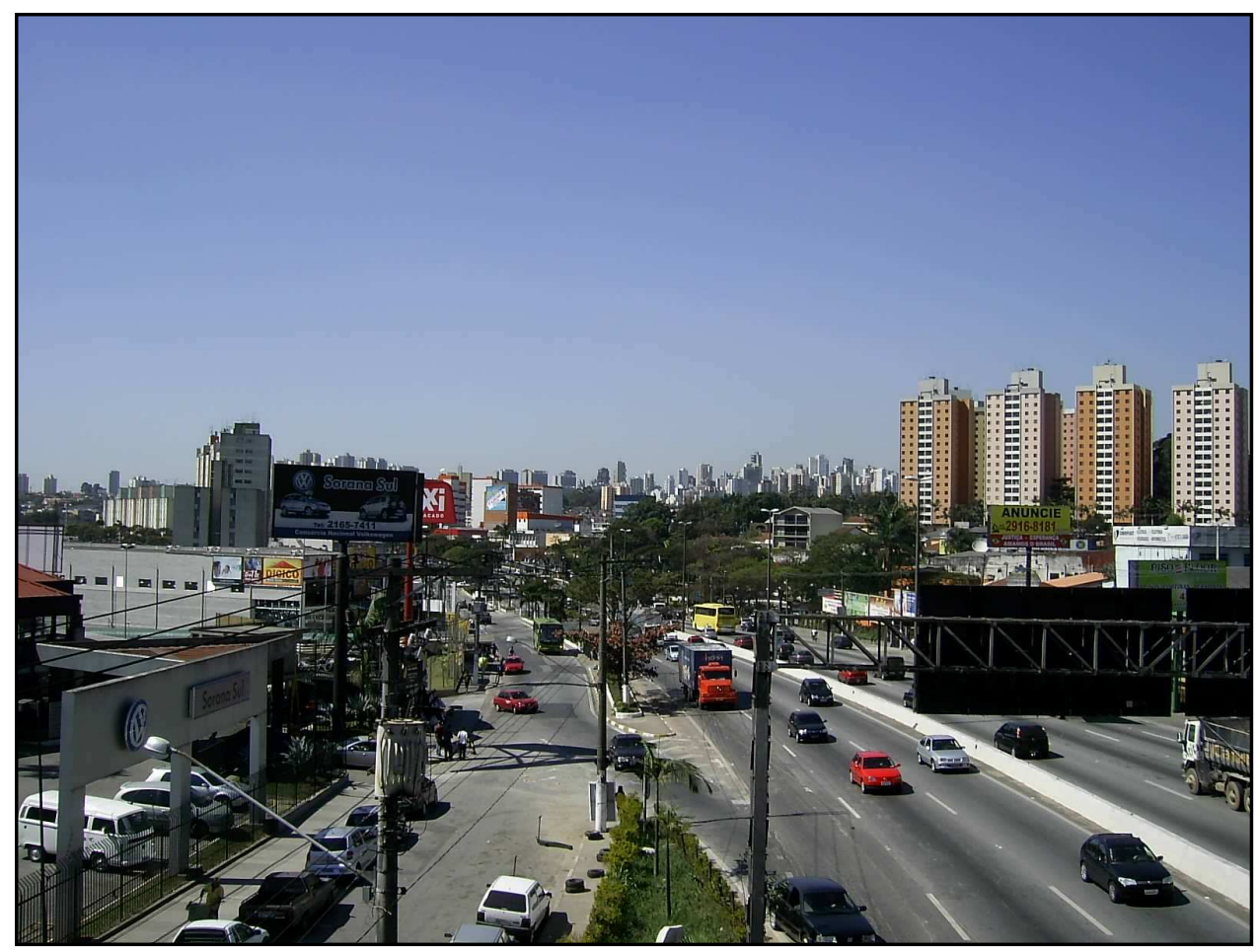

Foto 40 - Ocupação intensiva e extensiva da área central do município.

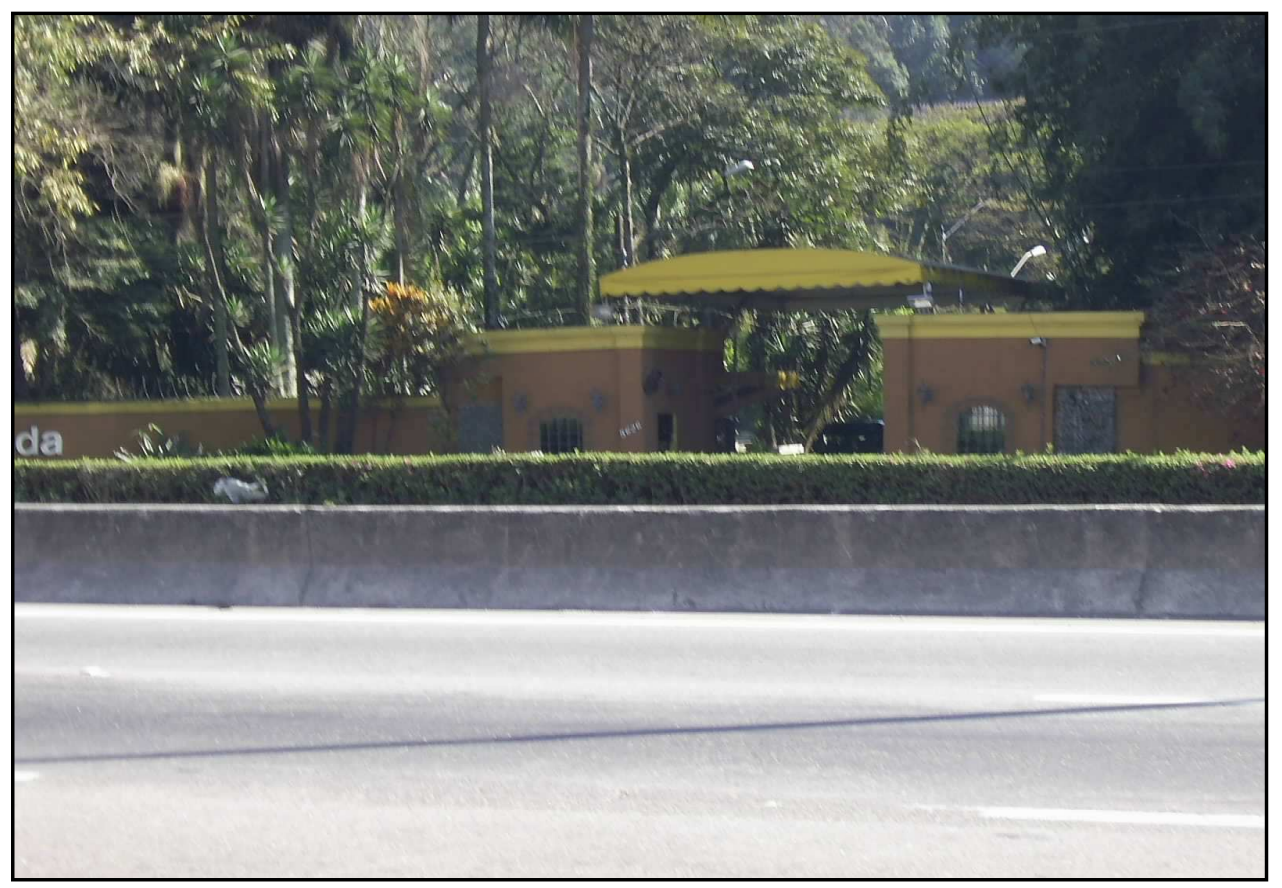

Foto 41 - Única área de ocupação humana

(moradia) com preservação da vegetação natural. Jardim Yolanda. 


\section{CONSIDERAÇÕES FINAIS}

As pesquisas científicas voltadas para a análise do meio em conjunção com as modificações oriundas do fator humano, são na atualidade um desafio que se mostra cada vez mais necessário.

No mundo atual, onde as discussões acerca dos impactos ambientais decorrentes da má utilização dos recursos naturais são temas de inúmeros encontros mundiais, o dilema entre disponibilidade e uso racional desses recursos necessitam, de equacionamento e de estudos que colaborem na resolução dos problemas oriundos da constante utilização dos recursos naturais.

A natureza, seja ela mais ou menos antropizada, é constituída de diversas partes que formam um todo. Daí provém a dificuldade da realização de uma análise ambiental que integre os diversos fatores sociais e naturais, os quais elaboram espaços geográficos que não são iguais, levando em consideração seus fluxos de energia e suas características físicas e sociais.

As teorias elaboradas para a análise das complexidades do espaço geográfico ou davam ênfase demasiada às características físicas ou às humanas deixando as inter-relações em segundo plano ou sem uma discussão mais aprofundada.

Uma característica básica na análise e interpretação das características dos sistemas é o princípio da interdependência ou conectividade, podendo assim se analisar as características de um sistema através da compreensão de que os mesmos são formados por conjuntos de elementos que realizam trocas entre outros conjuntos de elementos por meio de ligações entre um sistema e seu ambiente.

Os sistemas ambientais físicos, podem ser descritos como sendo a representação da organização espacial resultante da interação dos componentes físicos como: clima, solo, vegetação, topografia, rochas, hidrografia etc. Estas características físicas 
adquirem novas formas de comportamento quando se analisa além deles o componente antrópico. Daí, se configura realmente a natureza das análises geográficas tendo como suporte o embasamento em teorias que respondam às necessidades da pesquisa, onde a relação natureza e sociedade seja analisada de forma objetiva.

A existência de inúmeros estudos relativos á evolução física e sobre as conseqüências do incremento demográfico na Região Metropolitana de São Paulo, tem na Geografia e na aplicabilidade dos estudos geossistêmicos como base desses estudos.

O município de Taboão da Serra/SP, como área de estudo, apresenta características físicas e humanas que são semelhantes a outros municípios da RMSP. A compactação do solo pelo incremento da atividade humana gera conseqüências negativas ao meio.

A escolha do município como objeto de estudo, deu-se por motivos da percepção como morador local, das constantes transformações físico-sociais pela qual passa este município desde o ano de 2002. Transformações de ordem econômica geram impactos diretos sobre o sítio urbano, o que torna essencial o estudo integrado dos componentes físicos e sociais para perceber a natureza e a abrangência desses impactos.

O relevo torna-se importante característica física evidenciando que suas propriedades exercem influência direta na organização do Espaço Geográfico. Dentre essas características as propriedades geoecológicas sofrem transformações que em contrapartida direcionam o modo pelo qual a sociedade ocupa o relevo.

A presente pesquisa, levou em consideração como balizadores do estudo o significado dessas transformações nas 
propriedades geoecológicas e suas resultantes em termos da organização social em Taboão da Serra.

De acordo com a proposta da pesquisa, de analisar as modificações espaciais, considerando a urbanização como fator dinamizador dessas transformações em Taboão da Serra, encontramos dificuldades, principalmente no que diz respeito ao material necessário para se fazer a interpretação visual dessas modificações.

As imagens de satélites disponíveis, ou não cobriam épocas anteriores a década de 1970, ou não estavam disponíveis para trabalhos acadêmicos. Tal fato, demonstra que as instituições das gestões estaduais e municipais formam uma espécie de corporativismo, mantendo a ferramenta (imagem) como objeto de domínio das prefeituras.

Optou-se como saída para esse problema, o uso das ortofotos, pois, se constituem num meio mais acessível, tanto por se apresentar como imagem próxima da realidade, como também por representar o uso do solo em escala compatível com a base cartográfica.

Os vôos aerofotogramétricos constituem-se ainda hoje, uma opção para as análises ambientais, principalmente para aquelas de caráter urbano pois, representam uma forma mais barata de realizar uma análise das modificações no uso da terra comparando dois momentos distintos da área em questão.

Num primeiro momento, procuramos caracterizar a área de estudo elaborando cartas das diferentes propriedades como: hidrografia, geologia, relevo, clima, vegetação e uso da terra.

As dificuldades e dúvidas encontradas para se atingir esse objetivo, foi a princípio metodológico pois, a comparação da evolução urbana em 2 épocas distintas poderia criar barreiras para se atingir o objetivo da pesquisa. No caso, buscou-se não só 
interpretar como essa evolução criou impactos modificando o meio, como também discutir a influência das propriedades naturais sobre o modo de organização espacial do município.

Tomar como base, apenas, as características econômicas em detrimento das condições ambientais, como parâmetro de análise para se diagnosticar os níveis de "stress"do meio, tornar-se-ia discutível e sem efeitos no que diz respeito à comprovação da hipótese de estudo.

Resolveu-se portanto, utilizar a comparação "temporal" da área total do município em dois momentos distintos, como parâmetro, tendo como apoio a ferramenta do Geoprocessamento que insere-se no SIG (Sistema de Informação Geográfica) aliados num segundo momento com as características humanas da ocupação local.

As cartas resultantes, explicam a natureza dos impactos ambientais oriundos da urbanização quando são analisadas em conjunto. A carta clinográfica ou de declividades contribuiu para a visualização de como a população ocupa o relevo e quais são as feições superficiais que mais estão impactadas, modificando assim os fluxos hídricos principalmente nas vertentes da parte sudoeste do município, onde estão localizados os bairros mais populosos e de baixo poder aquisitivo.

Com relação às características geomorfológicas e do relevo do território do município, observa-se que a ocupação das feições do relevo se dá principalmente obedecendo o poder aquisitivo da população, em que as áreas menos acidentadas são ocupadas pelas classes de maior poder aquisitivo onde as moradias tem alto padrão de acabamento e as áreas verdes são preservadas.

As áreas mais acidentadas, principalmente as feições das vertentes, caracterizadas por alto grau de inclinação, são ocupadas pelas classes mais baixas da população, onde também 
ocorre o recorte abrupto dos taludes provocando a maximização dos movimentos de encostas desestabilizando toda a vertente.

O modelado tem como principal traço seu basculamento em direção às bacias do rio Pinheiros e Tietê, do qual são tributários os córregos Pirajussara e Poá, no entanto esta característica, oriunda de um soerguimento, tem como fator adicional a presença de um substrato rochoso de características geológicas antigas de uma época de clima seco. O quaternário contribuiu para a modificação das estruturas rochosas externas e internas, através da mudança do clima, de seco para mais úmido, erodindo estruturas e retrabalhando os blocos rochosos internos pela percolação das águas pluviais como também pela modificação dos fluxos endorreicos e exorreicos.

Atualmente a paisagem é transformada de maneira negativa pela compactação do uso do solo, tanto pela retirada da cobertura vegetal, quanto pelo recorte indiscriminado das feições do relevo.

O espigão que se localiza na parte central do município e que é uma feição do relevo que faz a divisa das duas sub-bacias hidrográficas, foi utilizada para servir de suporte à construção da principal via local (rodovia Régis Bittencourt), entretanto é a região onde se localiza as principais áreas de alta urbanização, como também da zona industrial. Por outro lado, as vertentes desse espigão são ocupadas pela população de baixa renda, avançando sobremaneira até as áreas de várzeas principalmente do córrego Pirajussara, este fator aliado à retirada da mata ciliar e ao entulhamento do córrego por lixo e restos de construções provoca em épocas de altos índices de pluviosidade as enchentes, problema grave que provoca prejuízos aos munícipes e para a prefeitura.

A carta geológica local demonstra que as características das rochas do substrato do município, são na verdade características contínuas que ocorrem na maioria dos municípios da RMSP, tal 
estrutura, por ter sofrido basculamento e desgastes pela percolação das águas e movimentações internas apresentam-se frágeis que define a interdependência dos elementos internos e externos, onde as modificações ocorridas na parte superficial terão reflexos na parte interna do substrato rochoso. Esse substrato, tem características geológicas resultante de rochas gnáissico-graníticas que sofreram rompimentos na sua estrutura, formando blocos basculados que fazem parte de um sistema natural juntamente com as falhas e os chamados "mosaico de blocos" que são naturalmente frágeis e que qualquer mudança superficial na propriedades geoecológicas gera imediatamente impactos na sua estrutura sub-superficial.

A respeito das propriedades geocológicas da área de estudo, consideramos que elas são balizadoras sim da forma de apropriação do relevo, e de que a ocupação intensiva do município de Taboão da Serra gerou impactos que atualmente apresentam processos-respostas no Estrato Geográfico e que resultam num ônus para a sociedade.

Ao analisar as propriedades do relevo local, percebe-se que o mesmo é caracterizado como sendo parte de um conjunto mais amplo de um sistema que mantém ligações com os compartimentos existentes. Dessa forma, a bacia Sedimentar de São Paulo está interligada com o embasamento pré-cambriano que forma o substrato da área do $A B C D$ e de regiões circunvizinhas abrangendo municípios como Embu, Cotia, Osasco e principalmente Taboão da Serra que espacialmente está localizada na divisa imediata entre a cidade de São Paulo/Butantã e o mesmo.

O relevo é a principal característica física que sofre os efeitos da urbanização e do adensamento demográfico, caracterizado pela ocupação de suas diversas formas, a começar pelas encostas. Concentradas na sua maior parte na região sudoeste do 
município, estas importantes formas do relevo foram gradualmente sendo desmatadas e ocupadas de forma indiscriminada, o que gerou impactos superficiais e sub-superficiais nos atributos naturais.

A rodovia Régis Bittencourt ou BR-116 Sul, é uma obra de engenharia que gerou impactos no relevo da cidade, recortando terrenos e rebaixando outros, contribuindo na instalação de sistemas de encostas criadas, modificando o fluxo superficial.

A ocupação das encostas na área periférica da cidade, evidencia uma problemática gerada pela utilização intensiva dessas formas de relevo, caracterizada pela falta de estrutura das edificações, principalmente na questão de engenharia de suas fundações. Soma-se a isto, a cultura de retirada gradual e total da cobertura vegetal dessas encostas e sua posterior compactação não só pelas construção civil, como também pela cimentação dessas encostas, exercendo influência direta nos fluxos hídricos e na modificação do sistema de percolação natural das águas pluviais, como também no balanço de evapotransipiração.

O estudo das propriedades reinantes do clima na área de estudo e em particular, do regime pluviométrico, mostrou-se como essencial para a análise geral dos atributos naturais e de como eles são interdependentes. A problemática das inundações mostrou-se ser resultado direto do modo de ocupação do sítio urbano, o qual gerou uma estrutura superficial construída que elimina os sistemas de escoamento natural por uma superficial, nociva ao meio e à sociedade.

O uso intensivo do solo, principalmente pela ocupação das áreas de várzeas, a retirada da mata ciliar que protegem os córregos aliadas às concentrações de episódios de alta pluviosidade geram os episódios de inundações, que é o problema mais agudo para a prefeitura local nos meses de verão, vindo em seguida a ocupação das encostas, em especial aquelas com alto 
grau de declives, que são ocupadas pelas camadas da população com baixo poder aquisitivo (como por exemplo nos bairros periféricos de São Judas, Saint Moritz, Jardim Pirajussara etc.).

Apesar de apresentar rios que são na realidade córregos sendo os principais: o Pirajussara e o Poá, suas áreas de várzeas se acham urbanizadas, e são bastante utilizados como canais de esgotos e lixões, estes aspectos sociais aliados ao desmatamento da mata ciliar são os principais problemas enfrentados pelos canais fluviais do município, não sendo um aspecto negativo só da área como de toda região metropolitana de São Paulo.

A RMSP (Região Metropolitana de São Paulo), a despeito de sua expansão, apresentou nos últimos 40 anos, uma aglutinação de áreas que antes eram rurais ou de uso não urbano que nos leva a inferir que essa aglutinação, gerou impactos negativos, tornando os regimes fluviais e pluviais problemas ambientais, tanto pela ocupação das áreas ribeirinhas por uma população de baixa renda, como também pela compactação e cobertura do solo, contribuindo para a dificuldade do escoamento das águas das chuvas.

A despeito de sua diminuta área territorial, criou-se um ambiente de insalubridade e de desconforto térmico, priorizando o antrópico (construções) sobre o natural (áreas verdes), onde as propriedades geoecológicas (relevo/clima/vegetação/rochas) estão sofrendo constantes modificações.

A comparação da evolução da urbanização em dois momentos distintos num espaço de 40 anos, através das cartas de Uso da Terra em 1962 e 2007 foi essencial para a interpretação visual das modificações espaciais de alguns atributos naturais como a cobertura vegetal, demonstrando que o avanço da urbanização contribuiu para a diminuição efetiva das áreas verdes do município. Essa evolução urbana da RMSP do qual faz parte o município de Taboão da Serra, provocou e ainda provoca impactos 
ambientais que modificam as propriedades geoecológicas desestruturando as propriedades geoecológicas préestabelecidas, principalmente nas áreas periféricas da cidade, onde as várzeas dos córregos são amplamente ocupadas modificando a estrutura natural das sub-bacias hidrográficas.

O caráter geossistêmico que buscou-se dar à pesquisa tem relação com a relação de valor dado em cada momento histórico de apropriação do espaço em Taboão da Serra, considerando que há 40 anos esse valor era diferente do atual, representando nos dias de hoje um valor mais quantitativo do que qualitativo, já que ao se ocupar o solo urbano não se leva em consideração se suas características naturais são empecilho para esta ocupação, importando mais o econômico (posição, proximidade, vantagens).

Em termos de prognoses para o município de Taboão da Serra/SP, faz-se necessário, através do poder público e com a participação efetiva da população local, de uma reestruturação das políticas de uso do solo local.

A participação efetiva da população, requer repensar as políticas de educação ambiental, o que pode evitar o entulhamento da rede hidrográfica pelo lançamento de lixo doméstico, como também, pela aplicação de uma nova política de uso do solo colocando em prática o Plano Diretor Municipal. 


\section{REFERÊNCIAS BIBLIOGRÁFICAS}

ABREU, A. A A Teoria Geomorfológica e sua Edificação: Análise Crítica. Revista do Instituto Geológico, vol 4, p. 5-23, São Paulo.1983.

Considerações a Respeito dos Fundamentos Conceituais das Classificações Geomorfológicas Utilizadas no Brasil. In Boletim Paulista de Geografia, vol.53. São Paulo. 1982.

Do Pátio do Colégio ao Planalto Paulistano: Problemas Geomorfológicos Emergentes do Sítio Metropolitano. FFLCH/USP. São Paulo.1983.

Significado e Propriedades do Relevo na Organização do Espaço. Boletim de Geografia teorética, 15 (2930): 154-162. São Paulo.1985.

AB'SABER, A. N. Conceito de Geomorfologia a Serviço das Pesquisas Sobre o Quaternário. Geomorfologia. São Paulo, n.18.1968.

Os Domínios de Natureza no Brasil: Potencialidades Paisagísticas. Ed. Ateliê Editorial. São Paulo. 2003.

ALMEIDA, F F M. Fundamentos Geológicos do Relevo Paulista. Boletim Instituto Geológico e Geográfico., v.41, p. 169-263, São Paulo, 1964 .

AMARAL, R.: Unidades ecodinâmicas: análise da fragilidade ambiental do Parque Estadual do Morro do Diabo e entorno,Teodoro Sampaio/SP. Dissertação de Mestrado. Faculdade de Filosofia, Letras e Ciências Humanas (FFLCH/USP). São Paulo. 2005. 
FERRARI, J. A. Paisagem e Ambiente; Impactos Sociais e Ambientais em Unidades de Conservação. FFLCH.USP. Mestrado.São Paulo.2007.

ANDRADE, M. C. Geografia Ciência da Sociedade: Uma Introdução a Análise do Pensamento Geográfico. Atlas. 143. P.São Paulo., 1987,

AOUAD, M.S. Tentativa de Classificação Climática para o Estado da Bahia. Dissertação de Mestrado.FFLCH/USP.São Paulo. 1978 .

ARAujo, W. T. Análise do Uso e Ocupação do Sìtio Urbano e dos Movimentos de Massa em Salvador Utilizando Geoprocessamento: Estudo de caso: Alto do Peru. IGEO-UFBA. Salvador. 2003.

ARONOFF, S. Geographic Information System: A Management Perspective. Wd2 Publications. Ottawa 1989.

AZEVEDO, J. Geossistemas e Paisagem Urbana. Ed. Sagres. São Paulo.1994.

BAGNOULS, F.; GAUSSEN, H. Saison sèche et indice xerothérmique. Faculté de Sciences de Toulouse. Toulouse.1953.

BAHR, A.; KARLSRUHE, K. GIS and Geoprocessing. Oxford Unversity. London. 1998.

BEROUTCHACHVILI, N; ROUGERIE, G. Geosystèmes et Paysages: Bilan et Méthodes. ED. Armand Colin. Paris. 1991.

BeRTALANFFy, L. von. Teoria Geral dos Sistemas. Editora Vozes Ltda. São Paulo. 1973.

BERTRAND, G. Paisagens, Geografia Física Global. Esboço Metodológico. Caderno de Ciências da Terra. Vol.13. USP.Instituto de Geografia. São Paulo.1971. 
La Science du Paisage, une Science

Diagonale. Toulouse. Ver. Geographie dês Pyrinées et Du SudOuest. T.43. Fasc.2.127-133. Toulouse. 1972.

BOLÓS,C. M. Manual de Ciencia Del Paisaje: Teoria,Metodos y Aplicaciones. Editora Masson. Collección de Geografia. Barcelona. España. 1992.

BOUCHARD, A.; DOMON, G. The Transformations of The Natural Landscapes oft Haut-Saint-Laurent (Quebec) And Their Implications on Future Resource Management. Landscape Urban Plan. 37: 99-107. Montreal. 1997.

BOUCHARD, A. Systems and Geoprocessing. H Press. New York. 1997.

BOUCINHAS, A. Superando Antagonismos entre Natureza e Cidade: Desenho Participativo em Taboão da Serra. FAU-USP. São Paulo/SP.2006.

BUDEL, J. Climatic Geomorphology. Princeton University Press. New Jersey/USA. 1982.

BURRough,P.A. Principles of Geographical Information Systems for Land Resources Assessment. Oxford: University Press, Oxford. 1994,.

BURROUGh,P.A. \& McDONELL, R.A. Principles of Geographical Information Systems. Spatial Information Systems and Geostatistics. Oxford University Press. p. 194 Oxford/UK. 1998.

CÂMARA, G. Anatomia de Sistemas Geográficos de Informações. Editora Sagres. Curitiba/PR.1997.

CASSETI, V. Ambiente e Apropriação do Relevo. Ed.Contexto.2 $2^{a}$ Ed. São Paulo. 1995.

CHORLEY, R.J.; KENNEDY. B. A. Physical Geography: a Systems Approach. Prentice Hall, Londres/UK 1971. 
CHORLEY, R. J.; HAGGET, P. Modelos Físicos e de Informação em Geografia. EDUSP. São Paulo/SP.1975.

ChRISTOFOlETTI, A. As Teorias Geomorfológicas. Notícias Geomorfológicas; 13(25);3-42. Campinas/SP.1980.

Geomorfologia. Editora Edgard Blucher Ltda. 2 Edição. São Paulo/SP.1996.

Modelagem de Sistemas Ambientais.

Editora Edgard Blucher. IGCE. Unesp.São Paulo/SP. 1989.

COPPOLANI, j. La Population de Toulouse en 1975. Arrêt Dans la Croissance de la Ville de Toulouse. Revue Géographique des Pyrénées ET Du Sud-Ouest. Tome 48. Fasc. 01. PP.9-32. Toulouse. 1977.

COUTINHO, J.M.V.. Projeto Integração Geológica da Região Metropolitana de São Paulo, 1:50.000. 28 folhas cartográficas e relatório final. São Paulo/SP. 1980.

CREPANI, E. Sistemas de Informação Geográfica. São José dos Campos/SP.1996.

. Sensoriamento Remoto e Geoprocessamento Aplicados ao Zoneamento Ecológico-Econômico e ao Ordenamento Territorial. INPE. São José dos Campos/SP. 2001.

D'ÉRCOLE .R. Revue de La Association de les Geographes Français. Paris IV. Paris. 1995.

DOUGLAS, I. In k,j.GREGORY- A Natureza da Geografia Física. Ed Bertrand Brasil. Rio de Janeiro/RJ. 1985.

DRAMSTAD, W. Landscape Ecology Principles in Landscape Architecture and Land-Use Planning. Washington/USA. 1996.

EMBRAPA. Centro Nacional de Pesquisa de Solos. Sistema Brasileiro de Classificação de Solos. Rio de Janeiro/RJ, 1999. 
FAUGÉRES,L. Risques Naturels, Risques Urbains. Bulletin de L'Associatión de Géographes Français. Mars. 72ํㅡ Année.Paris. 1995.

FOSTER, B. An Examination of Some Problem and Solutions In Urban Monitoring From Satellite Platforms. International Journal of Remote Sensing: 6(1):p. 139-151, New York/USA 1985.

GALVANI, E. Estudo Comparativo dos Elementos do Balanço Hídrico Climatológico para Duas Cidades do Estado de São Paulo e para Paris. Confins [Online], 4 |.11/2008.

GEORGE, P. Geografia Econômica. Ed. Edgard Blucher. São Paulo.1973.

GIGLIOLI, G.R. L’Erosione del Terreno Agrario nei Tropici. Instituto Agricolo Coloniale Italiano. Firenze/ITA. 1978.

GODARD,A. Vulnerabilitée en Millieu Urbaine. Bulletin de L'Associatión de Géographes Français. 75ํㅡㄹ Anée. Septiembre. Paris. 1988 .

GOMES e VELHO. Spring (Sistema de Processamento de Imagens Georreferenciadas) INPE. São José dos Campos/SP. 2002 .

GONÇALVES, N. M. S. Impactos Pluviais e Desorganização do Espaço Urbano em Salvador-Bahia. Tese. Doutorado em Geografia Física. FFLCH. USP. São Paulo/SP. 1992.

GOVÁGUA/USP. Grupo de Pesquisa Govágua/USP PROCAM USP.São Paulo. 2007.

GRIGORIEV, A. A. The Theorethical Fundaments of Modern Physical Geography. The Interaction of Sciences in the Study of the Earth.p.77-91, Moscou. 1968. 
GUERRA, A.J.T.; CUNHA, S.B. Impactos Ambientais Urbanos no Brasil. Editora Bertrand Brasil. 2 Edição. Rio de Janeiro/RJ. 2001.

HAGGET.R.J. Earth Surface Systems. Springer Verlag, Berlin. 1985.

HARVEY, D. A liberdade da cidade. In GEOUSP - Espaço e Tempo. Nr. 26, PP.09-17, São Paulo/SP, 2009.

HORTON, R.E. Erosional Development of Streams and Their Drainage Basins; Hidrophysical Approach to Quantitative Morphology. Bull. Geol. Soc. Na. v.56.p.275-70, New York/USA. 1945.

IAC -Instituto Agronômico de Campinas. Solos do Estado de São Paulo. Campinas/SP. 1999.

JALABERT, G. Toulouse, Croissance et Crise. Revue Géographique des Pyrénées et du Sud-Ouest. Tome. 54. Fasc. 01. pp.7-30. TOULOUSE/FR. 1983.

Les Transformations de la Composition Sociale de la Ville de Bordeaux. Revue Géographique des Pyrénées et du Sud-Ouest. Tome 49. Fasc. 1. PP. 11-28. TOULOUSE/FR 1978.

L'évolution des Paysages Urbains De Toulouse Depuis de 1945. Revue Géographique des Pyrénées et du Sud-Ouest. Tome 49. Fasc. 03. PP.343-356. TOULOUSE/FR. 1978.

KAWAKUBO, F. S. Representações gráficas do relevo e álgebra de mapas: aplicações no estudo da fragilidade ambiental. Dissertação de Mestrado. Faculdade de Filosofia, Letras e Ciências Humanas (FFLCH).São Paulo/USP. 2005. 
KIENAST, F. Analysis of Historic Landscape Patterns with a Geographical Information System - A Methodological Outline. Landscape Ecology. 8: 103-118. 1993.

LEME, S. M. Relevo, processos geoecológicos e sócio/ reprodutores e a fragilidade ambiental da bacia do ribeirão Piracicamirim-SP. Faculdade de Filosofia, Letras e Ciências Humanas (FFLCH). USP. Tese (doutorado). Geografia Física. São Paulo-SP, 2007.

LEPSCH, I.F. Formação e Conservação dos Solos. Oficina de Textos. São Paulo/SP. 2002.

LOMBARDO, M. A. Il ha de Calor na Metrópole Paulistana.Tese de Doutoramento. Universidade de São Paulo. USP. Brasil. São Paulo/SP. 1984.

Qualidade Ambiental e Planejamento Urbano: Considerações de Método. Livre-Docência. USP. São Paulo/SP. 1995.

LIBAULT, A. Os Quatro Níveis da Pesquisa Geográfica. Métodos em Questão in 1 IGEO-USP. São Paulo/SP. 1971.

MILDNER,W.F. Erosion and Sedimentation. Bullettin of the Association of Engineering Geologists, v.19n nr 02. p.161-166. New York/USA. 1982.

MONTEIRO, C. A. de F. A Dinâmica Climática e as Chuvas do Estado de São Paulo: Estudo Geográfico sob a Forma de Atlas. São Paulo. Instituto de Geografia da USP. São Paulo/SP. 1973.

. Teoria e Clima Urbano - IGEOG -USP Série Teses e Monografias n 25. São Paulo/SP 1976.

. Geossistemas: A História de uma Procura.

Ed. Contexto, São Paulo/SP. 2000. 
NAVEH, Z \& .LIEBERMAN,A.S. Landscape Ecology: Theory and Application. Springer Verlag. Berlin. 1998.

NIERO, M. Utilização de Dados Orbitais do Landsat na Classificação de Uso do Solo Urbano de São José dos Campos/SP.. INPE,(INPE-1295-TPT/093). São José dos Campos/SP. julho de 1978.

NYÉRGES,A.et all. Le Systémes de Vulnerabilitée. Bulletin de L’Associatión de Géographes Français. 77ํ․ Année. Octobre. Paris. 1997.

O'HARA, C.G. KING,R.L. Multitemporal Land Use and Land Cover Classification of Urbanized Areas within Sensitive Coastal Evironments. IEEE Transaction on Geoscience and Remote Sensing. Vol. 41, no 09, pp. 2005-2014. New York/USA .2003.

OKE T.R. The City as an Ecosystem. Progress in Physical Geography 5, 315-67. London. 1987.

.Boundary Layer Climates.. Routledge,

London.1987.

Climate Change and Urban Environmment.

Press Canada. 1998.

Urban Observations, Instruments and Methods of Observation Programme, in press IOM Report, World Meteorology Organization., Geneva/Italy. 2004.

PAILHÉ, J. L'Evolution de la Population de L'Áquitaine. Revue Géographique des Pyrénées et du Sud-Ouest. Tome 47 Fasc. 4 , pp. 321-342, TOULOUSE/FR. 1976.

PEREIRA, R.R. Planejamento territorial: suas implicações para a promoção da Saúde e da Justiça Ambiental. In GEOUSP Espaço e Tempo. Nr. 26, pp. 19-27, São Paulo/SP. 2009. 
RIBEIRO DA SILVA, W. Novos Centros, Novas Centralidades, Novas Diferenças: A Fragmentação do Espaço Urbano de Londrina. Geografia,29 (1): 55-74 jan-abr. 2004 (Geografia, volume 29, numero 1, janeiro a abril de 2004, pg. 55-70. Associação de Geografia Teorética (AGETEO). Rio Claro/SP.2004.

RODRIGUES, M. Geoprocessamento. Simpósio Brasileiro de Geoprocessamento. Editora da Escola Politécnica da USP/ EPUSP. São Paulo/SP. 1997.

ROSA, R. A. Utilização de Imagens TM/LANDSAT em Levantamento de Uso do Solo. In: VI Simpósio Brasileiro de Sensoriamento Remoto, Manaus,.Anais. v.2, p.419-425. INPE. São José dos Campos/SP. 1990

ROSS, J. L. S. Análise Empírica da Fragilidade dos Ambientes Naturais e Antropizados. In: Revista do Departamento de Geografia n॰8, FFLCH-USP, São Paulo/SP, 1994.

Estruturas $e$ as Formas do Relevo Brasileiro. In Geografia do Brasil. São Paulo/SP. EDUSP. 1996. Geomorfologia: Ambiente e Planejamento. $2^{\underline{a}}$ Edição. São Paulo/SP. 1996.

Aplicação de SIG na Geração de Cartas de Fragilidade. Revista do Departamento de Geografia. N. 13. São Paulo/SP.1999.

- Ecogeografia do Brasil: subsídios para planejamento ambiental. $1^{\text {a }}$ Edição.. Subsídios para planejamento ambiental. São Paulo/SP. 2006.

O Registro Cartográfico dos Fatos Geomorfológicos e a Questão da Taxionomia do Relevo. In: Revista do Departamento de Geografia $n^{\circ} 6$, FFLCH-USP, São Paulo/SP. 1992. 
SANTO, S. M. A Água em Feira de Santana: Uma Análise do Bairro Rocinha. Dissertação de Mestrado. IGEO/UFBA. Salvador/BA. 1995.

SCHEIDEGGER. A. E. Theoretical Geomorphology. Springer Verlag, 2 Edição. Berlim/Alemanha Oc. 1970.

SEADE. Fundação Sistema Estadual de Análise de Dados. Secretaria de Economia e Planejamento do Estado de São Paulo. São Paulo/SP. 2007.

SERRA FILHO, R.,et alli.. Levantamento da Cobertura Vegetal Natural e do Reflorestamento no Estado de São Paulo. 2a ed. Instituto Florestal. Boletim Técnico, 11. São Paulo /SP, 1975.

SMYTH, C. G. \& ROYLE, S.A. Urban landslide hazards: incidence and causative factors in Niterói, Rio de Janeiro State, Brazil. Applied Geography, [S.I.], v. 20, p.

117. London. 2000.

SMITH,T.R. Requirements and Principles for the Implementation and Construction of Large-Scale Geographic Information Systems.: Taylor \& Francis, n.1. London. 2002.

SOMEKH, N. A Cidade Vertical e o Urbanismo Modernizador: São Paulo 1920-1939. Editora da FAU/USP. São Paulo/SP. 1994.

SORRE, M. Los Fundamentos Biológicos de la Geografia Humana. Ensayo de una Ecologia del Hombre: Concusion. In: MENDOZA, J. G.; JIMÉNEZ, J. M.; CANTERO, N. O. (Org.) EI Pensamiento Geográfico: Estudio Interpretativo y Antología de Textos (De Humboldt a las Tendências Radicales),: Alianza Editorial: 267-274. Madrid/Espanha. 1982.

SOTCHAVA, V. B. O Estudo de Geossistemas. Editora EPUSP. São Paulo/SP. 1977. 
SPÖRL, C.; ROSS, J. L. S. Análise Comparativa da Fragilidade Ambiental com Aplicação de Três Modelos. GEOUSP - Espaço e Tempo, , № 15, pp.39-49, São Paulo/SP. 2004.

TARIFA, J.R. Fluxos Polares e as Chuvas de Primavera-Verão no Estado de São Paulo: Instituto de Geografia/USP, (Teses e Monografias). São Paulo/SP. 1975.

tARIFA, J. R. ; AZEVEDo, T. R. . O Ritmo Semanal das Atividades Humanas e o Clima na região Metropolitana de São Paulo. Geousp, v. 9, p. 09-35, São Paulo/SP. 2001.

TITARELLI, A.H.V. Alteração do Clima Local nos Centros Urbanos: Efeitos Adversos da Urbanização. Caderno Prudentino de Geografia n 03, IPEA-UNESP. Presidente Prudente/SP. 1982.

TRICART,J. Principles et Méthodes de la Géomorphologie. Masson et Ca.Saint Germain. Paris VI. Paris/Fr.1965.

Ecodinâmica. Editora IBGE-Supren (Recursos Naturais e Meio-Ambiente) Rio de Janeiro/RJ.1977.

. Introductión à la Geomorphologie Climatique.Paris V.Paris/Fr.. 1965.

TUCCI, C.E.M. Hidrologia: Ciência e Aplicação. Editora da Universidade/ABRH, cap.1, p.25-33, cap.22, p.849-75. Porto Alegre/RS. 1993.

VAlente, O. F.; CAStRo,P.S. A Bacia Hidrográfica e a Produção de Água. Informe Agropecuário, v.09, p.54-6. Belo Horizonte/MG. 1983.

VILLELA, F.N. Fragilidade potencial do relevo - estudo geomorfológico da bacia hidrográfica do Ribeirão Mococa Cristais Paulista - SP. Dissertação de Mestrado. Faculdade de Filosofia, Letras e Ciências Humanas (FFLCH/USP). São Paulo/SP. 2005. 
VIERS, G. Elementos de Geografía. Geomorfologia. ED. Oikostau.Barcelona/Espanha.1975.

WILSON, L. Dynamic Geomorphology. Reinhold Book . p.297301. Corporation, New York/USA. 1968

WOLMAN,M.G. ; MILLER, J.P. In CHRISTOFOLETTI, A. Magnitude e Frequência das Forças nos Processos Geomorfológicos. Notícia Geomorfológica, v.14 nr.27/28. p.3-43, São Paulo/SP. 1974. 